\title{
Economic Geology of the
}

\section{Platinum Metals}

By JOHN B. MERTIE, JR.

GEOLOGICAL SURVEY PROFESSIONAL PAPER 630

A summary report on the geology of the

platinum deposits of the world, with a

discussion of the chemistry and mineralogy

of the platinum group of metals and a

comprehensive bibliography

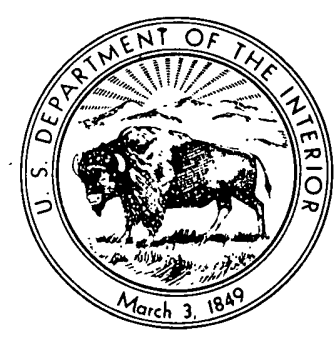




\section{UNITED STATES DEPARTMENT OF THE INTERIOR}

WALTER J. HICKEL, Secretary

\section{GEOLOGIGAL SURVEY}

William T. Pecora, Director

Library of Congress catalog-card No. GS68-389

For sale by the Superintendent of Documents, U.S. Government Printing Office

Washington, D.C. 20402

9

723656309 


\section{CONTENTS}

Abstract.

Introduction.

World production

Platinum metals

Physical properties...................

Chemical properties and analyses. . . . . .

Mineralogy-

Natural alloys of platinum metals............

Chemical compounds of platinum metals

Platinum deposits

Distribution

Classification

Lodes.

Classification of platinum lodes......... Placers

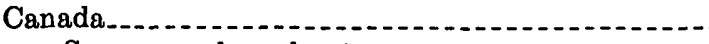

Sources and production

Ontario

Sudbury district. .......................

Discovery and present mining

General geology

Intrusive rocks.

Ore deposits

Platinum metals...

Other lodes. . . .

Manitoba...

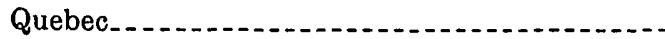

Northwest Territories.

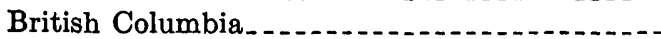

Lodes.

Placers

Tulameen district.................

Other placers

Yukon

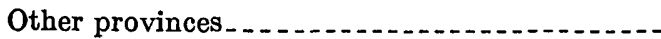

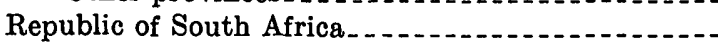

Transvaal and Orange Free State Provinces....

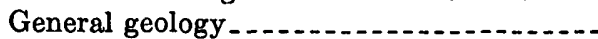

Bushveld complex. . . . . . . . . . . . .

Ore deposits..........

Magmatic segregates...............

Merensky zone..................

Chemical analyses............

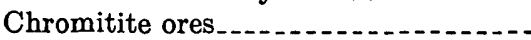

Dunite ores..............................

Pneumatolytic, hydrothermal, and contact metamorphic ores...............

Placers of the Witwatersrand district.-

History and production.

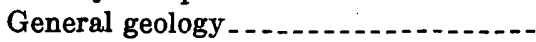

Deposits.

Chemical composition..............

Cape of Good Hope Province.
Platinum deposits-Continued Page

Republic of the Congo (Katanga)

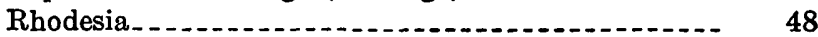

Ethiopia............... 49

Sierra Leone.

Union of Soviet Socialist Republics_._._._._._. 51

History and production...... 51

Ural Mountains........................ 51

Lodes

Placers. ...

Sources.......... 55

Physiography.... 56

Deposits_............. 56

Chemical analyses.

Noril'sk district........... 60

Petsamo district........................... 62

Minor deposits....... 63

Colombia............ 63

History and production

Intendencia del Choc6́.................... 64

Geography

General geology

Gold-platinum placers...... 66

Nariño Province_...

Chemical analyses.

Australia. . . . . . . .

Tasmania_...

New South Wales_..... 71

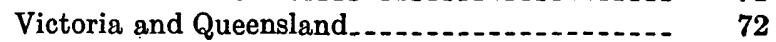

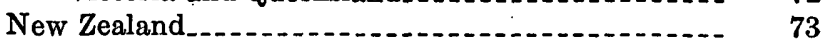

Papua, Territory of New Guinea, and Netherlands

New Guinea..... 73

Borneo and Sumatra.

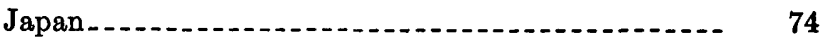

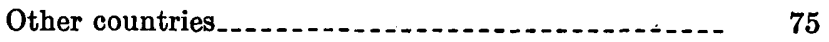

United States_.

Alaska_.

Lodes

Salt Chuck mine... 76

Placers.

Goodnews Bay district._._._..... 77

Mining and production......... 77

Earlier and recent surveys....... 79

General geology ............ 79

Deposits_._.

Geochronology . . .

Platinum metals and gold........- , 84

Chemical analyses............. 87

Other Alaskan deposits.......... 88

Chemical analyses............ 89

Platiniferous placer gold.......... 90

Exploration in Alaska...... 91 
Platinum deposits-Continued

United States-Continued

California.

Placers.

Deposits...............................

Chemical analyses..................

Colorado

Idaho

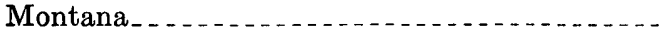

Stillwater Complex

Green Mountain copper mine........

Placers

Nevada
Platinum deposits-Continued United States-Continued

Oregon $\quad 99$

Placers

Takilma-Waldo district... . . . . . . . 99

Applegate district.... 100

Pacific beaches............. 100

Washington $\ldots \ldots 1$

Wyoming . . . . .

Recoveries from refineries . . . . . . . . . . . 101

Bibliographies.

Foreign bibliography ................ 102

United States bibliography _...

Index .

\section{ILLUSTRATIONS}

Plate 1. Geologic map of the Goodnews platinum district, Alaska

1. Geologic map of "nickel irruptive," Sudbury district, Ontario

2. Generalized geologic map showing location of gold-platinum placer deposits, Tulameen Valley, British Columbia.

3. Geologic map of norite and differentiated ultrabasic rocks of the Bushveld igneous complex and the Witwatersrand System, Transvaal and Orange Free State, Republic of South Africa

4. Index map showing dunite localities in the Ural Mountains 5-7. Geologic maps:

5. Nishniy-Tagil dunite massif

6. The Noril'sk district, Siberia.

7. Chocó platinum district, Colombia.

8. Sketch map showing location of principal mining claims on the Salmon River and its tributaries.......

\section{TABLES}

TABLE 1. Uses of platinum metals in the United States, 1965

2. World production of platinum metals, $1950-66$

3. Physical properties of the platinum metals, gold, and silver

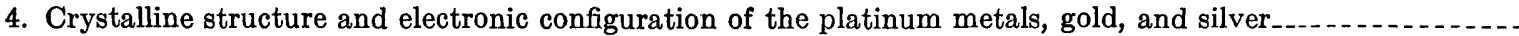

5. Natural isotopes of the platinum metals, gold, and silver

6. Alloys of platinum metals

7. Platinum minerals, named and unnamed.

8. Analyses of sperrylite.

9. Spectrographic analyses of sperrylite

10. Distribution of platinum metals

11. Platinum metals in platinum minerals, Sudbury district.

12. Platinum metals in ores from Falconbridge mine, Subdury district

13. Spectrographic data on platinum and palladium in ore minerals, Subdury district

14. Mean tenors of platinum metals in common ore minerals, Sudbury district.

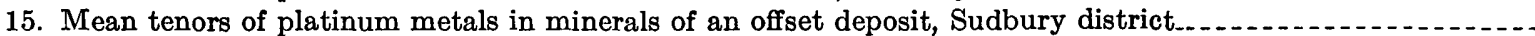

16. Contents of platinum, rhodium, and palladium in the principal ore minerals of marginal deposits, Sudbury district

17. Contents of platinum, rhodium, and palladium in the principal ore minerals of an offset deposit, Sudbury district. 
TABLES 18-20. Composition of platinum metals:

18. Tulameen district....................

19. In sulfide and oxidjzed ores, Rustenburg district.

20. Mainly from Rustenburg district

21. Analyses of platinum metals at Onverwacht mine

22. Composition of osmiridium from Witwatersrand

23. Analyses of primary platinum, Nishniy-Tagil district

24. Mean analyses of placer platinum metals, Ural Mountains 25-33. Analyses of-

25. Placer platinum from Vilni Basin, Siberia

26. Placer platinum of Timpton Valley ...

27. Platinum metals from Colombia.

28. Osmiridium from Colombia

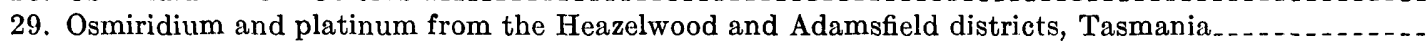

30. Platinum metals, Fifield district, New South Wales...

31. Platinum metals, Goenoeng-Lawack region, Borneo

32. Osmiridium, Goenoeng-Lawack region, Borneo

33. Osmiridium, Hokkaido Island, Japan . . . .

34. Composition of electromagnetically separated platinum alloy and of its soluble and insoluble fractions, Goodnews Bay district.

35. Analyses of platinum metals showing dross, Goodnews Bay district

36. Percentages of platinum metals, gold, and impurities, Goodnews Bay district.

37. Percentages of platinum metals, Goodnews Bay district 38-40. Analyses of-

38. Alaskan placer platinum metals

39. Placer gold, Yukon Valley, Alaska.

40. California placer platinum metals . .

41. Incomplete analyses of California placer platinum metals

42. Analyses of rocks from the Stillwater Complex, Montana...

43. Analyses of platinum metals from Pacific beaches of Oregon 


\title{
ECONOMIC GEOLOGY OF THE PLATINUM METALS
}

\author{
By John B. Mertie, JR.
}

\begin{abstract}
Platinum was discovered first in Colombia, but the exact date is unknown, though it was described as early as 1557. Mining of the platinum placers of Colombia began in 1778, and until 1823 this state was the only source of the platinum metals. Rich platinum placers were discovered in the Ural Mountains, between Russia and Siberia, in 1822, and within a few years Russia became and remained for many years the world's greatest producer. Placer platinum was mined in Canada as early as 1885, but it was not until 1919 that the platinum metals began to be recovered from the nickel-copper lodes of the Sudbury district. By 1936, Canada had become a producer of first rank. Platinum was found in the Transvaal, Republic of South Africa, in 1923, and the deposits of the Bushreld complex were discovered in the following year. In 1956 and 1957 the output of these lodes outstripped the Canadian production, though in later years the South African production was deliberately reduced for economic reasons. Russia for a long time ranked third, but as the Uralian placers became depleted, lodes were found in Siberia that by 1961 raised the Russian output to first rank. Platinum placers were discovered in Alaska in 1929, and since 1934 this State has ranked fifth in world production, with Colombia fourth. The Witwatersrand district, of South Africa, ranks sixth, but nevertheless is the world's greatest producer of osmiridium (iridosmine).

Placer deposits of the platinum metals occur throughout the world, and up to the end of the first quarter of the 20th century constituted all the world's supply. The discovery of the platiniferous lodes of Canada and South Africa, and later those of Siberia, completely altered this situation. As of 1965, the three largest producing countries were the Union of Soviet Socialist Republics, the Republic of South Africa, and Canada, which together produce more than 98 percent of the world's output; Colombia and the United States together contribute $1 \frac{1}{2}$ percent, and a few other nations add the remainder. Judging by the exploration already done, the Republic of South Africa appears to have the largest reserves.

The six platinum metals occur commonly in placers as two intergrown alloys, of which one has a high tenor in platinum, a much lower tenor in iridium, and small tenors in the other four elements, The second alloy consists mainly of iridium and osmium, with considerable ruthenium, less rhodium and platinum, and an exceedingly small amount of palladium, if any.

The platinum metals that occur in bedrock lodes exist mainly as platinum minerals, wherein the platinum elements, gold, silver, and certain base metals function as cations in combination generally with arsenic, antimony, bismuth, sulfur, tellurium, oxygen, and other anions. Small amounts of native alloys

are also present in some bedrock ores, notably in those of the Transvaal, Republic of South Africa.

A genetic classification of the platinum lodes and placers constitutes a part of this report. In the discussion of lodes, six types of host rocks or environments are enumerated. The two major lode systems are exemplified by the basic rocks of the Sudbury district, Ontario, Canada, and by the basic and ultrabasic rocks of the Transvaal, Republic of South Africa, both of which occur in elongate elliptical basins which have been designated as lopoliths. This simllarity has suggested a genetic uniformity in the origin of the intrusive rocks and of the related nickel-copper-platinum lodes at these two sites, but this is fallacious. The intrusive rocks of Sudbury include few if any ultrabasic rocks; they have not been proven to have originated by magmatic or gravitative differentiation, and the platiniferous lodes occur mainly, not within the intrusives, but either along the margins of the intrusive rocks, or as offset deposits at considerable distances from them. The igneous rocks of the Bushveld complex, in the Transvaal, include basic and many types of ultrabasic rocks; they are generally admitted to have resulted from magmatic differentiation, and the principal platinum horizon, the Merensky reef, occurs in ultrabasic rocks far from the bounding sedimentary rocks.

A third type of lode comprises those deposits of the platinum metals which occur in peridotites and perknites, commonly in dunite and serpentinite, less commonly in pyroxenic rocks containing little or no olivine. The distinctive feature of these lodes is that the platinum metals occur as native alloys, which are either concentrated in lenticular masses of chromite, or are sparsely and widely distributed in association with chromite, within the ultrabasic rocks. Such deposits have yielded no major lodes of economic value though some small ore bodies of this kind have proven to be of phenomenally high grade. By prolonged erosion and alluvial concentration, however, the platinum metals of these deposits have been concentrated to produce stream and beach placers, mainly the former. Lodes of this type have been the sources of the placens of the Russian Urals, Colombia, Alaska, and so far as known, of all the other platinum placers of the world. The three other types of ores, mentioned in a later section (p. 17), have little significance. either as lodes or sources of placers, though a few of them have been mined, generally with little or no profit.

The genetic classification of the platinum placers is similar to what the writer has elsewhere used for gold placers. Seven types of placers are listed, including the lithified placers exemplified by the gold-osmiridium deposits of the Witwatersrand, Republic of South Africa. Most of the alluvial deposits
\end{abstract}


described in this report are either ancient or recent stream placers.

The physical and chemical properties of the platinum metals are stated in the following pages, and their mineralogy is fully discussed. Two tabulations are presented that attempt to separate the alloys from the chemical compounds, or true minerals. A large number of analyses of the platinum metals, mainly of the natural alloys, are given; whereas the analytical data on the platinum metals recovered from lodes are based mainly on the records of production. But even the analyses of the native metals are composite, in that they are based commonly upon bulk samples of two alloys. Chemical analyses are rated by the writer as superior or inferior according to whether or not they state the percentages of all the platimum metals of the samples. Several firms in the United States are able to make superior analyses, but outside the analyses made by Johnson, Matthey and Co. for the Goodnews Bay Mining Co., Alaska, very few superior analyses are obtainable.

This report is devoted mainly to a description of the more important platinum deposits of the world, of which three are productive on a major scale and three on a minor scale. Other deposits that were formerly mined, some that now produce small amounts of the platinum metals, and other that have geologic rather than economic significance are also described. If the data are available, the topics discussed are the discovery, mining and production, general geology, character and genesis of the deposits, and the composition of the platinum metals. Canadian, South African, Russian, and Colombian deposits are rather fully discussed; in lesser detail are also described the sources of the platinum metals in Australia, New Zealand, Japan, Ethiopia, Sierra Leone, New Guinea, Borneo, Sumatra, and other countries. The deposits of Alaska are described in considerable detail, partly because they are of national importance and partly because many cogent data on them are available.

Two bibliographies are presented, one of foreign occurrences of the platinum metals and one of domestic occurrences. Papers relating to some of our domestic deposits are shown in both bibliographies.

\section{INTRODUCTION}

The earliest recorded use of platinum, according to Farabee $(1921$, p. $43-52)$, was by the Indians of Ecuador, who made artifacts of platinum bonded by gold, before the discovery of America by Europeans. Probably the first allusion to platinum was made by the Italian Julius C. Scaliger (1557) in his book entitled "On Subtlety" (in Latin). The Spaniard, Antonio de Ulloa (1748, p. 606), in describing his travels in South America, mentioned the occurrence of "platina" in the Chocó district. The first investigative work was done by Charles Wood, an English metallurgist and assayer, who acquired some platinum in Jamaica in 1748 that had come from Cartagena (Colombia), and he sent a part of it to a relative, Dr. William Brownrigg, in London. Dr. Brownrigg investigated the properties of the new metal, and in 1750 presented samples to the Royal Society of London. Shortly thereafter, Sir William Watson (1750, p. 671-676) and Dr. Brownrigg contributed to the
Philosophical Transactions a careful description of platinum. Later and more detailed studies of platinum residues led to the discovery of palladium and rhodium by William $\mathrm{H}$. Wollaston (1805), and of iridium and osmium by Smithson Tennant (1805). Ruthenium was separated in impure form by G. W. Osann (1827), and was later purified and described by Karl K. Klaus (Carl E. Claus) $(1845,1847)$. These and many additional details of the discovery of the platinum metals are admirably presented by Weeks and Leicester (1968). A complete history of the platinum metals, from the time when platinum was discovered until 1890, has been written by Donald McDonald (1960b) and published by Johnson, Matthey and Co., of London. This company also publishes a quarterly journal entitled the "Platinum Metals Review," of which the first issue appeared in January 1957. The most important treatise on the platinum metals of recent date is by Heinrich Quiring (1962, 288 p.)

Mining of the platinum placers of Colombia began in 1778 , and these deposits remained the only source of the platinum metals until the Russian deposits were discovered. Platinum was found first in the gold placers of the Ural Mountains in 1822, but rich platinum placers were discovered in 1824, which made Russia the world's largest producer, with Colombia second. The declining production from the Russian placers has in recent years been compensated in large measure by the recovery of platinum metals as a byproduct in mining the nickel-copper ores of the Noril'sk district, northwestern Siberia, and other lodes.

Platinum was recognized in Canada in 1852 , and platinum placers were mined as early as 1887. Platinum was discovered in the Sudbury district, Canada, in 1885, but it was not until 1919 that production from the nickel-copper mines of that district began on a large scale. By 1936, Canada had become a producer of first rank.

Osmiridium was first found in South Africa in 1892, and the first recorded discovery of platinum in the central Transvaal was in 1923. Commercial production of platinum metals from the nickel-copper ores of the Bushveld igneous complex began in 1925, and in 1956 and 1957 the Republic of South Africa was the largest producer of the platinum metals. In subsequent years, however, this output was purposely curtailed, to meet the demands of the metal markets. Osmiridium (iridosmine) began to be produced commercially in 1921, and in recent years the output has remained relatively constant, as this alloy is a byproduct of gold mining in the Witwatersrand. This production, though small, is the world's principal source of osmiridium, which 
formerly was produced by Russia, Tasmania, Japan, and Papua.

The uses to which the platinum metals are put vary from year to year, as new industrial applications are devised. The latest data, as given for 1965 by the U.S. Bureau of Mines, are shown in table 1.

The chemical and electrical industries utilize nearly three-quarters of the platinum metals produced by and imported into the United States. Especially noteworthy is the large amount of palladium used by the electrical industry, and it may be noted that 350,000 ounces of palladium was used by the telephone companies in 1964 for contacts, mainly in relays. Both palladium and platinum are used by the oil industry as catalysts, but the lower cost of palladium gives it preference over platinum, where the substitution is possible. Only about 5 percent of the total available palladium is used for jewelry; because it is lighter than platinum it is used for brooches and large ornaments where it is desirable to reduce weight. The illegally produced and refined platinum (see section on "Colombia") is unsatisfactory for purposes where specified alloys are required, such as catalysts, and this accounts for its diversion into the jewelry trade. It is significant that, owing to the high resistance of the platinum metals to chemical corrosion, most of the uses are nondestructive, so that an increasing volume of secondary platinum metals is being recovered.

TABLE 1.-Uses, in ounces, of the platinum metals in the United States, 1965

[Source: U.S. Bur. Mines]

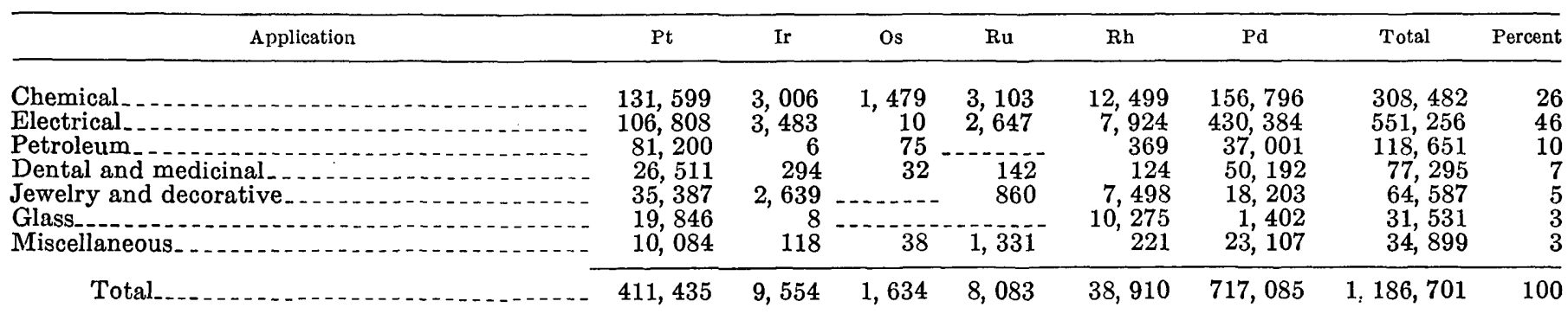

One of the interesting national uses to which platinum was formerly put was the coinage by Russia of 3-, 6-, and 12-ruble coins, which began in 1828 and continued until 1846. These three coins had weights respectively of $0.333,0.666$, and 1.332 troy ounces, or approximately $10.358,20.715$, and 41.431 grams; and their diameters were approximately 23,28 , and 36 millimeters. Thus the 3-ruble coin was comparable in size with a U.S. quarter dollar, which has a diameter of about 24 millimeters. According to McDonald (1960b, p. 165), quoting Deville and Debray, the composition of the Russian ruble coins, recomputed to total 100 percent, was as follows:

Composition of Russian platinum coins

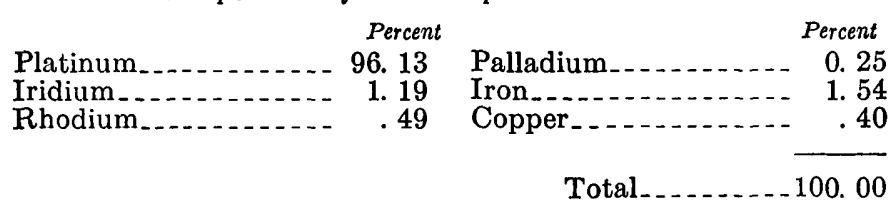

It also is stated by McDonald that 1,373,691 coins of 3 rubles, 14,847 coins of 6 rubles, and 3,474 coins of 12 rubles were minted, with a total content of 485,505 troy ounces of platinum. Any of these are now con- sidered rare items by coin dealers in the United States.

The platinum metals have different values, depending mainly upon their desirability for different uses, and their natural plenitude or scarcity. The market price of ruthenium remained constant during 1966 and the first 4 months of 1967 , but the prices of the other five metals increased steadily during the same period, according to the following tabulation:

$$
\begin{aligned}
& \text { Market prices of platinum metals in } 1966 \text { and part of } 1967 \\
& \text { [Dollars per troy ounce] }
\end{aligned}
$$




\section{WORLD PRODUCTION}

The Union of Soviet Socialist Republics, the Republic of South Africa (exclusive of the Witwatersrand), and Canada had productions in 1965 respectively of $1,700,000,750,000$, and 463,000 troy ounces, derived mainly from lodes, though in part (Russia) from placers. Canada was the largest producer of platinum metals (exclusive of osmiridium) from 1936 to 1955 and from 1958 to 1960 . The Republic of South Africa was the largest producer in 1956 and 1957, but a collapse in the metal markets in 1958 resulted in a temporary curtailment of the South African output. In the "Platinum Metals Review," of 1966 and 1967, however, the Rustenburg Platinum Mines, Ltd., principal South African producer, announced a marked expansion in mining activities that will result in a production of 850,000 ounces by 1969 .

Lack of exact information renders it difficult to appraise correctly the Russian output, as the U.S.S.R. does not make public its production of many mineral products, particularly those of strategic value. Up to 1953, the production of the U.S.S.R. was estimated nominally by the U.S. Bureau of Mines at 100,000 ounces, but the volume of platinum metals ${ }^{1}$ imported by the United States from Russia during the Second World War was so great as to indicate either that the nominal estimate of an annual production of 100,000 ounces was a gross underestimate, or that the platinum metals had been stockpiled in Russia over a considerable number of years. Therefore, beginning in 1954, the Russian output was estimated by the U.S. Bureau of Mines at 200,000 ounces, and this figure has been increased gradually to a maximum of $1,700,000$ ounces for 1965. Thus, in 1961, the Union of Soviet Socialist Republics became, and has remained, the principal producer of the platinum metals.

Regardless, however, of comparative outputs the reserves and therefore the potential production of the Republic of South Africa appear to be much greater than those of any other country. One marked difference between the South African lodes and those of Canada and the U.S.S.R. is that platinum metals are the principal output of the former, with a byproduct of nickel, copper, and other metals, whereas in the two latter countries the reverse is true.

Colombia, the United States, and the Witwatersrand, of the Transvaal and Orange Free State, had annual productions, respectively, for 1965 of $11,040,40,487$, and 6,000 troy ounces, but these outputs require some explanation. The production of Colombia is obtained

1 Data acquired from the War Production Board, 1945. from placers which are mined by dredging, but in addition, thousands of natives are also engaged in mining on a very small scale. The individual outputs of these people are small, but in the aggregate their production considerably exceeds that of the dredges. Most of this individually mined gold and platinum is purchased by speculators who smuggle it out of the country, and therefore such platinum is not officially recorded. Hence, the production stated by the Colombian government, and accepted by the U.S. Bureau of Mines, may probably be doubled. Parenthetically, much of this smuggled and illegally processed platinum is not carefully and completely refined, but this does not detract from its use in jewelry. Hence, a large part of it is channeled into the jewelry business.

The output given for the United States includes the plätinum metals produced in placer mining, together with those that are recovered as a byproduct of the mining of gold and copper lodes. In addition, there is an important increment that results from the salvage of industrial wastes and from jewelry and dental products that were saved and reworked. The Goodnews Bay Mining Co. is the only concern in the United States that is engaged primarily in mining the platinum metals, though a very small output is also obtained as a byproduct of gold dredging in California. Therefore the Goodnews production may not be specifically cited, but instead is included with the other primary sources above cited. The production from Goodnews Bay, however, is less than that given for Colombia.

Certain districts in North America, Asia, Africa, and Oceania that formerly had outputs in excess of 1,000 ounces are now either very small producers or nonproducers. Present or past minor sources are in the following countries or parts thereof:

1. Katanga (Republic of the Congo). A byproduct of the copper lodes, recovered in the refineries.

2. British Columbia.

3. California, Oregon, and other Western States.

4. Australia, including Tasmania, New South Wales, Victoria, and Queensland.

5. Ethiopia.

6. Sierra Leone.

7. Papua, Territory of New Guinea, and Netherlands New Guinea.

8. Borneo and Sumatra.

9. Japan.

10. Several other countries with present or former outputs of very small size. 
Panama is not included in the list of minor producers, though it was credited with an output of 267 ounces in 1937. No significant production, however, is recorded before or after that date, and it is probable that a part of the output of 1937 was platinum that was smuggled out of Colombia.

The world's total production of platinum metals has not been accurately recorded, but it believed, as of 1965 , to be about 42,500,000 troy ounces, and the annual production in the United States constitutes only 1.2 percent of the world's annual production.

The statistics of the world's production of platinum metals for the period 1882-1966 are given in the "Mineral Resources" volumes (1882-1923) of the U.S. Geological Survey and in the "Minerals Yearbooks" (192466) of the U.S. Bureau of Mines. A valuable compilation of world production, classified by countries and by platinum alloys, has recently been published by Quiring (1962, p. 93-101). The world's production of platinum metals by countries from 1951 to 1966 will suffice as a necessary background for the contents of this report. These data are presented in table 2.

Canada produces about equal amounts of platinum and palladium; about 72 percent of the output of the Republic of South Africa is platinum, but 70 percent of the Russian production is palladium. As Russia has the largest output, it follows that more palladium is produced in the world than platinum. The output ratio of palladium to platinum is about $3: 2$.

\section{PLATINUM METALS PHYSICAL PROPERTIES}

The platinum group of metals comprises platinum, iridium, osmium, ruthenium, rhodium, and palladium. Platinum, iridium, and osmium have the greatest density, and iridium is now recognized as the heaviest element that occurs in nature. Ruthenium, rhodium, and palladium have densities that average only 55 percent as great. Thus these six elements are divided by their densities into two sets, which are analogous to gold and silver, and just as native gold is invariably alloyed with silver, so all six of these elements are invariably present as native alloys of the platinum metals.

The platinum metals may be tabulated in different ways, but the listing used in this exposition begins with platinum and ends with palladium, as they are the most plentiful of these elements, and in a circular arrangement would adjoin one another. Platinum, iridium, and osmium are arranged in their order of de- creasing atomic number and atomic weight and increasing melting point, boiling point, and hardness. Ruthenium follows osmium, because these two hexagonal elements should be together. Rhodium occupies the remaining fifth place in the tabulation. The principal properties of the platinum metals are shown in tables 3-5. In the compilation of these data, a number of sources were consulted, and the most reasonable and consistent were accepted. Among the sources utilized were Bishop and Co. (1931), Vines and Wise (1941), Gilchrist (1943), Zryagintsev (1946), Selwood (1956), Way and others (1950), Wise (1953), Wise and Gilchrist (1949), Engelhard Industries, Inc. (1965), and Johnson, Matthey and Co., Ltd. (1963).

The platinum metals, as shown in table 3, are paramagnetic, as opposed to gold and silver, which are diamagnetic. Palladium has the greatest and osmium the smallest magnetic susceptibility. Palladium has a higher magnetic susceptibility than any other nonferromagnetic element so far determined. The magnetic susceptibility and other physical properties of the natural alloys of the platinum metals cannot be predicted by linear interpolation based upon the known proportions of their elements, and in fact, unexpectable properties may exist in such alloys or compounds. Thus, certain natural alloys of the platinum elements are ferromagnetic though none of the pure metals are ferromagnetic. This has frequently been explained by the presence of a high content of iron in the dross, coupled perhaps with a high tenor of palladium, but such assumptions are not necessarily valid, as pyrite $\left(\mathrm{FeS}_{2}\right)$ has a high content of iron, but is not ferromagnetic. Ordinary hematite $\left(\mathrm{Fe}_{2} \mathrm{O}_{3}\right)$ is likewise paramagnetic, though maghemite $\left(\gamma-\mathrm{Fe}_{2} \mathrm{O}_{3}\right)$ is ferromagnetic. On the other hand, the Heusler alloys, containing commonly the paramagnetic elements manganese, aluminum, and copper, are strongly ferromagnetic, with a Curie point at $330^{\circ} \mathrm{C}$. Also, a weakly ferromagnetic element, in combination with some paramagnetic element, may yield a highly ferromagnetic alloy. Thus, Pertinax II, as described by Darling (1963, p. 96-103) and Ford (1964, p. 82-92), which contains 76.7 percent platinum and 23.3 percent cobalt, is the most powerful permanent magnet so far developed. And finally, two diamagnetic elements may be combined to produce a ferromagnetic compound. An example is silver difluoride $\left(\mathrm{AgF}_{2}\right)$, with a Curie point at $-110^{\circ} \mathrm{C}$.

The natural alloys of the platinum metals are handled differently by producers than the natural alloys of gold and silver that constitute placer gold 
TABLE 2.-World production of platinum metals, in troy ounces, 1950-66 [Compiled from U.S. Bureau of Mines Yearbooks, 1950-66]

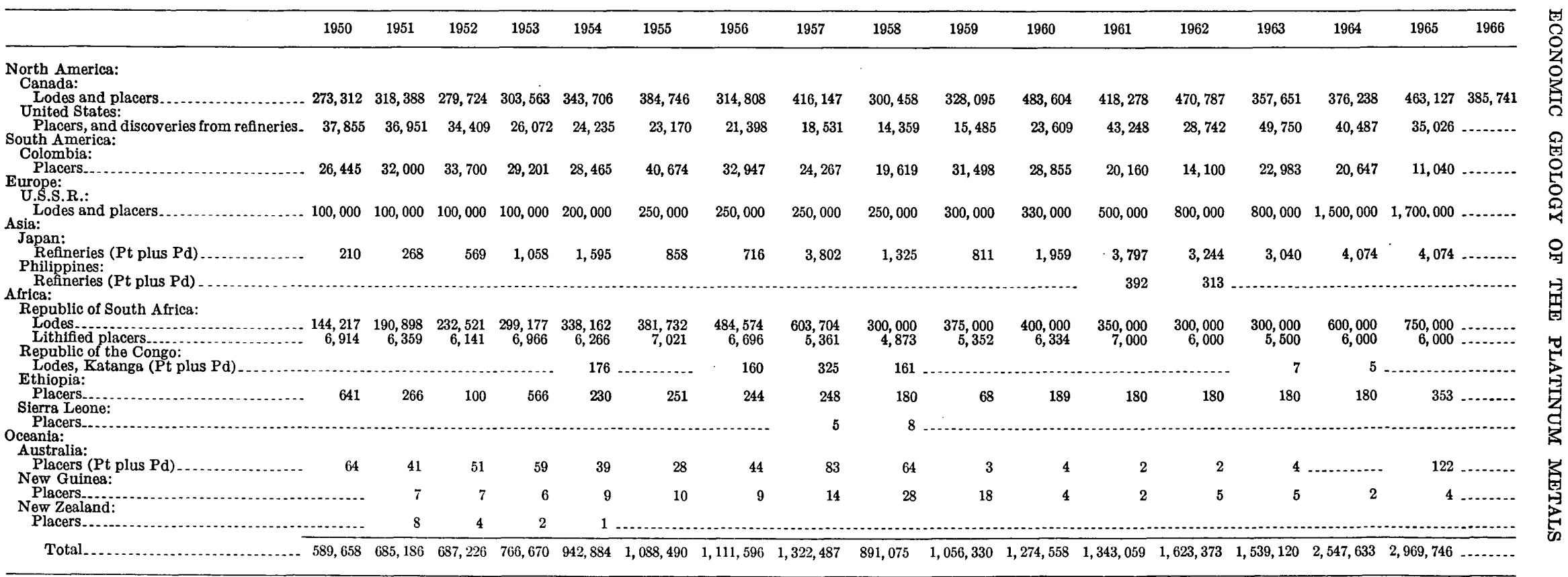


PLATINUM METALS

TABLE 3.-Physical properties of the platinum metals, gold, and silver

\begin{tabular}{|c|c|c|c|c|c|c|c|c|c|c|c|c|}
\hline Precious metals & $\begin{array}{l}\text { A tomic } \\
\text { number }\end{array}$ & $\begin{array}{l}\text { A tomic } \\
\text { weight }\end{array}$ & $\begin{array}{l}\text { Density } \\
\text { at } 20^{\circ} \mathrm{C}\end{array}$ & $\begin{array}{l}\text { Hardness } \\
\text { (Moh's } \\
\text { scale) }\end{array}$ & $\begin{array}{l}\text { Melting } \\
\text { point } \\
\left({ }^{\circ} \mathrm{C}\right)\end{array}$ & $\begin{array}{l}\text { Boiling } \\
\text { point } \\
\left({ }^{\circ} \mathrm{C}\right)\end{array}$ & $\begin{array}{c}\text { Common } \\
\text { valence } \\
\text { numubers }\end{array}$ & \multicolumn{5}{|c|}{ Workability } \\
\hline 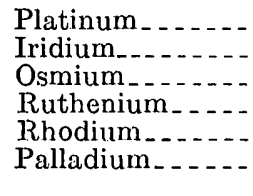 & $\begin{array}{l}78 \\
77 \\
76 \\
44 \\
45 \\
46\end{array}$ & $\begin{array}{l}\text { 195. } 2 \\
\text { 193. } 1 \\
\text { 190. } 2 \\
\text { 101. } \\
\text { 102. } 9 \\
106.7\end{array}$ & $\begin{array}{l}21.45 \\
22.65 \\
22.61 \\
12.45 \\
12.41 \\
12.02\end{array}$ & $\begin{array}{l}\text { 4. } 3 \\
\text { 6. } 5 \\
\text { 7. } 0 \\
\text { 6. } 5 \\
6.0 \\
\text { 4. } 8\end{array}$ & $\begin{array}{l}1,769 \\
2,443 \\
3,045 \\
2,310 \\
1,960 \\
1,552\end{array}$ & $\begin{array}{l}3,800 \\
4,500 \\
5,020 \\
4,080 \\
3,700 \\
2,900\end{array}$ & $\begin{array}{r}2,4 \\
3,4 \\
4,6,8 \\
3,4,6 \\
3 \\
2,4\end{array}$ & \multicolumn{5}{|c|}{$\begin{array}{l}\text { Malleable and ductile. } \\
\text { Brittle. } \\
\text { Do. } \\
\text { Brittle, cold. Malleable, red heat. } \\
\text { Do. } \\
\text { Malleable and ductile, but less so than } \\
\text { platinum. }\end{array}$} \\
\hline \multirow[t]{2}{*}{$\begin{array}{l}\text { Gold } \\
\text { Silver. }\end{array}$} & $\begin{array}{l}79 \\
47\end{array}$ & $\begin{array}{l}\text { 197. } 2 \\
107.9\end{array}$ & $\begin{array}{l}\text { 19. } 27 \\
10.50\end{array}$ & $\begin{array}{l}2.5 \\
2.7\end{array}$ & $\begin{array}{r}1,063 \\
961\end{array}$ & $\begin{array}{l}2,808 \\
2,210\end{array}$ & $\begin{array}{r}1,3 \\
1,2,3\end{array}$ & \multicolumn{5}{|c|}{$\begin{array}{l}\text { Very malleable and ductile. } \\
\text { Malleable and ductile, but less so than gold. }\end{array}$} \\
\hline & $\begin{array}{l}\text { Electrical } \\
\text { resistivity } \\
\text { (microhms } \\
\left.\mathrm{cm}^{3} \text { at } 0^{\circ} \mathrm{C}\right)\end{array}$ & $\begin{array}{r}\text { Spe } \\
\text { (cal/g/ }\end{array}$ & $\begin{array}{l}\text { cific heat } \\
1{ }^{\circ} \mathrm{C} \text { at } 0^{\circ} \mathrm{C} \text { ) }\end{array}$ & $\begin{array}{c}\text { Thermal } \\
\text { conductivity, } \\
\jmath^{\circ}-100^{\circ} \mathrm{C} \text { (call } \\
\mathrm{cm} / \mathrm{cm}^{2} / \mathrm{sec} /{ }^{\circ} \mathrm{C} \text { ) }\end{array}$ & $\begin{array}{l}\text { Ther } \\
\text { sivit } \\
\text { (mic) }\end{array}$ & $\begin{array}{l}\text { nal expan- } \\
, 20^{\circ}-100^{\circ} \mathrm{C} \\
0-\mathrm{cms} / \mathrm{cm})\end{array}$ & $\begin{array}{c}\text { Young's } \\
\text { modulus, } \\
E \\
\left(\mathrm{~kg} / \mathrm{mm}^{2} / \times\right. \\
\left.10^{-3}\right)\end{array}$ & $\begin{array}{c}\text { Shear } \\
\text { modulus, } \\
G \\
\left(\mathrm{~kg} / \mathrm{mm}^{2} / X\right. \\
\left.10^{-3}\right)\end{array}$ & $\underset{\substack{\text { Bulk } \\
\text { moduls, } \\
K \\
\left(\mathrm{~kg} / \mathrm{mm}^{2} / \times \\
10^{-3}\right)}}{ }$ & $\begin{array}{c}\begin{array}{c}\text { Index of } \\
\text { ductility, } \\
\frac{K}{G}\end{array}\end{array}$ & $\begin{array}{l}\text { Atomic } \\
\text { suscept } \\
\quad\left(\mathrm{cm}^{3}\right.\end{array}$ & $\begin{array}{l}\text { ic magnetic } \\
\text { tibility, } x_{A} \\
\left.{ }^{8} / \mathrm{g} / \times 10^{6}\right)\end{array}$ \\
\hline $\begin{array}{l}\text { Platinum } \\
\text { Iridium } \\
\text { Osmium } \\
\text { Ruthenium } \\
\text { Rhodium } \\
\text { Palladium } \\
\text { Gold } \\
\text { Silver }\end{array}$ & \multicolumn{2}{|c|}{$\begin{array}{l}\text { 9. } 85 \\
\text { 4. } 71 \\
\text { 8. } 12 \\
\text { 6. } 71 \\
\text { 4. } 33 \\
\text { 9. } 93 \\
\text { 2. } 06 \\
\text { 1. } 59\end{array}$} & $\begin{array}{r}0.0314 \\
.0307 \\
.0309 \\
.0551 \\
.0589 \\
.0584 \\
.0308 \\
.0559\end{array}$ & \multicolumn{2}{|c|}{$\begin{array}{r}0.17 \\
.35 \\
.21 \\
.25 \\
.36 \\
.18 \\
.74 \\
1.01\end{array}$} & $\begin{array}{r}9.1 \\
6.8 \\
6.1 \\
9.1 \\
8.3 \\
11.6 \\
14.2 \\
19.7\end{array}$ & $\begin{array}{r}17.40 \\
53.83 \\
56.00 \\
43.00 \\
38.64 \\
12.83 \\
8.02 \\
8.05\end{array}$ & $\begin{array}{r}6.22 \\
21.40 \\
22.00 \\
17.20 \\
15.30 \\
46.10 \\
2.82 \\
2.94\end{array}$ & $\begin{array}{l}28.09 \\
37.80 \\
38.00 \\
29.20 \\
28.01 \\
19.09 \\
17.46 \\
10.18\end{array}$ & $\begin{array}{l}\text { 4. } 52 \\
\text { 1. } 77 \\
\text { 1. } 73 \\
\text { 1. } 70 \\
\text { 1. } 83 \\
\text { 4. } 14 \\
\text { 6. } 19 \\
\text { 3. } 46\end{array}$ & & $\begin{array}{r}+189.6 \\
+25.7 \\
+9.9 \\
+43.4 \\
+101.9 \\
+558.1 \\
-29.6 \\
-22.7\end{array}$ \\
\hline
\end{tabular}

TABLE 4.-Crystalline structure and electronic configuration of the platinum metals, gold and silver

\begin{tabular}{|c|c|c|c|c|c|c|c|c|c|c|c|c|c|c|c|c|c|c|}
\hline \multirow{3}{*}{ Metal } & \multirow{3}{*}{ Crystalline structure } & \multirow{3}{*}{ Space group } & \multicolumn{15}{|c|}{ Electronic configuration } & \multirow{3}{*}{$\begin{array}{c}\text { Atomic radius } \\
\text { in angstroms } \\
\left(\mathrm{cm} \times 10^{-8}\right)\end{array}$} \\
\hline & & & \multirow{2}{*}{$\frac{K}{s}$} & \multicolumn{3}{|c|}{ L } & \multicolumn{3}{|c|}{$\mathbf{M}$} & \multicolumn{4}{|c|}{$\mathrm{N}$} & \multicolumn{3}{|c|}{0} & \multirow{2}{*}{$-\frac{P}{s}$} & \\
\hline & & & & s & t & $s$ & s & $\mathbf{p}$ & d & $\mathrm{s}$ & $\mathrm{p}$ & $\mathrm{d}$ & 1 & $\mathrm{~s}$ & $\mathrm{p}$ & $d$ & & \\
\hline 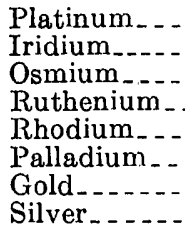 & $\begin{array}{l}\text { Cubic, Fcc. } \\
\text { Cubic, Fcc } \\
\text { Hexagonal, Cph. } \\
\text { Hexagonal, Cph } \\
\text { Cubic, Fcc. } \\
\text { Cubic, Fcc. } \\
\text { Cubic, Fcc. } \\
\text { Cubic, Fcc } \\
\end{array}$ & $\begin{array}{l}\text { Fm } 3 \mathrm{~m} \\
\text { Fm } 3 \mathrm{~m} \\
\text { C6/mmc... } \\
\text { C6/mmc... } \\
\text { Fm } 3 \mathrm{~m} \\
\text { Fm } 3 \mathrm{~m} \\
\text { Fm } 3 \mathrm{~m} \\
\text { Fm } 3 \mathrm{~m}\end{array}$ & $\begin{array}{l}2 \\
2 \\
2 \\
2 \\
2 \\
2 \\
2 \\
2\end{array}$ & $\begin{array}{l}2 \\
2 \\
2 \\
2 \\
2 \\
2 \\
2 \\
2\end{array}$ & 6 & 2 & $\begin{array}{l}2 \\
2 \\
2 \\
2 \\
2 \\
2 \\
2 \\
2 \\
2\end{array}$ & $\begin{array}{l}6 \\
6 \\
6 \\
6 \\
6 \\
6 \\
6 \\
6\end{array}$ & $\begin{array}{l}10 \\
10 \\
10 \\
10 \\
10 \\
10 \\
10 \\
10\end{array}$ & $\begin{array}{l}2 \\
2 \\
2 \\
2 \\
2 \\
2 \\
2 \\
2\end{array}$ & $\begin{array}{l}6 \\
6 \\
6 \\
6 \\
6 \\
6 \\
6 \\
6\end{array}$ & $\begin{array}{r}10 \\
10 \\
10 \\
7 \\
8 \\
10 \\
10 \\
9\end{array}$ & $\begin{array}{l}14 \\
14 \\
14\end{array}$ & $\begin{array}{l}2 \\
2 \\
2 \\
1 \\
1\end{array}$ & $\begin{array}{l}6 \\
6 \\
6\end{array}$ & $\begin{array}{l}9 \\
7 \\
6\end{array}$ & $\begin{array}{l}1 \\
2 \\
2\end{array}$ & $\begin{array}{l}\text { 1. } 38 \\
\text { 1. } 35 \\
\text { 1. } 32 \\
\text { 1. } 31 \\
\text { 1. } 34 \\
\text { 1. } 37 \\
\text { 1. } 42 \\
1.44\end{array}$ \\
\hline
\end{tabular}

Native gold is diamagnetic, so that most of the black sand that is not removed by washing may be separated magnetically. After sieving to remove the coarser lead shot that originated in the use of firearms, the gold is melted in the producer's gold room, and any remaining black sand or other heavy minerals are skimmed off the top of the molten gold, as cream is skimmed from milk. Any lead or solder that was not removed by sieving or hand picking is melted with the gold and this decreases its fineness. Finally, the gold is poured into molds to form gold bricks, and the skimmings are later cyanided to recover adhering gold.

Native platinum, for several reasons, cannot be handled by these methods. The platinum metals are paramagnetic in varying degrees, as shown in table 3, and a part of the natural cubic alloys may be ferromagnetic; therefore, all the minerals of the black sand cannot be removed magnetically. Crude placer platinum is first separated from the black sand concentrates by the use of a Wilfley or some other type of concentrating table. Screening of the dried metals and magnetic separation so far as permitted are then employed. Finally, an ingenious system of blowing the product fed from a vibrating hopper is employed by the Goodnews Bay Mining Co., by means of which successive fractions of the platinum alloys are collected in sectionalized boxes. This process, in a repetitive flowsheet, eliminates most of the remaining black sand and yields a product that contains about $\mathbf{1 1}$ percent of impurities. This final product is not melted by the producer, owing partly to the high melting temperatures of the platinum metals and partly to the fact that osmium and, to a lesser degree, ruthenium sublime. Melting would thus produce losses in osmium and ruthenium, and would in addition generate the poison- 
TABLE 5.-Natural isotopes of the platinum metals, gold, and silver

$[M=$ mass number; $P=$ number of protons; $N=$ number of neutrons

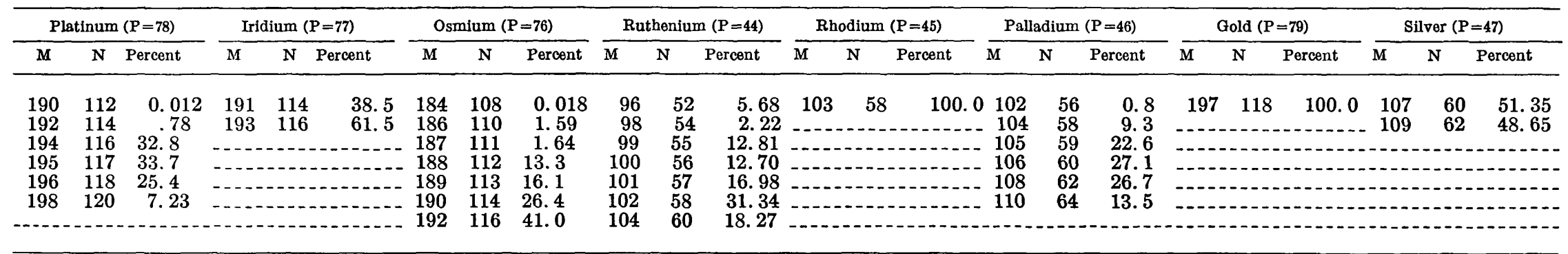

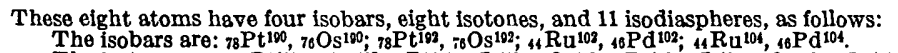

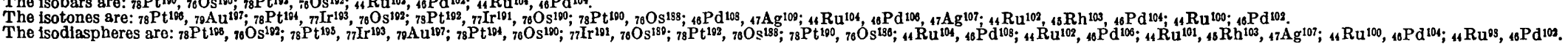


ous gas $\mathrm{OsO}_{4}$. Therefore, the final product is shipped in bulk to the refiner, where it is analyzed and processed by chemical treatment. Every cleanup from the dredge of the Goodnews Bay Mining Co. is thus processed and separately analyzed.

\section{CHEMICAL PROPERTIES AND ANALYSES}

Pure platinum is not attacked by the common inorganic acids, but is dissolved, though less readily than gold, by aqua regia. On the other hand, pure iridium and rhodium are not appreciably attacked by aqua regia or other inorganic acids, and osmium and ruthenium are quite insoluble in such acids. Palladium is dissolved not only by aqua regia but also by hot nitric or hot sulfuric acid. This vulnerability of palladium to acids is reflected in its inferior ability to withstand the effects of weathering and consequently by its superior tendency to form natural mineral compounds.

The platinum metals occur commonly in bedrock as two distinct alloys, which usually are intergrown in a pseudoeutectic fabric, but may also occur separately. As obtained from placer deposits, however, these two alloys are invariably mixed, and any chemical analysis of placer platinum therefore represents the sum of two different products, intermingled in an unknown ratio. Only rarely is it possible to obtain a pure sample of either alloy. Chemically, these alloys behave differently, in their reactions with acids and other reagents, than the purified platinum metals, and moreover, these reactions are not quantitatively predictable, because they depend upon the compositions of the alloys, which are inconstant. Hence, even the best analyses will fail to show either the composition of the individual alloys or their existing ratios, though certain guiding principles, hereafter enumerated in discussing different placers, may render possible a general understanding of the natural and proportions of the component alloys.

Bulk samples of the platinum metals from placers are prepared for analysis, and also subsequently for refining, by dissolving them in hot aqua regia. In this procedure, most of the platinum, parts of the iridium and rhodium, and all the palladium are dissolved, but the osmium and ruthenium are unaffected and have to be gotten into solution by another method. The proportions of the soluble and insoluble fractions vary with different samples, according to the composition of the component alloys and their ratios, so that no general statement is warranted. In a typical sample of the platinum alloys recovered by the Goodnews Bay Mining Co., Alaska, it was found that 98.1 percent of the platinum, 18.5 percent of the iridium, 66.7 percent of the rhodium, and all the palladium were dissolved in hot aqua regia. The remainder of the platinum, iridium, and rhodium and all the osmium and ruthenium constitute an insoluble fraction that is otherwise processed.

The solubilities of the platinum metals in one another and in certain base metals has an important bearing upon the composition of their natural alloys. Gold and silver, in laboratory preparations, are miscible in all proportions, with well-defined solidus and liquidus curves, yet, the proportion of gold in native gold-silver alloys is rarely less than 60 percent, as shown by Mertie (1940, p. 93-124). The explanation of this phenomenon may be related to the formation of such alloys as hydrothermal rather than magmatic products. The platinum metals have different crystallographic properties that limit the amounts of these metals and the dross that constitute the two principal alloys. Thus the cubic platinum metals show continuous solidus and liquidus curves, but they appear not to be miscible in all proportions in nature, though the limits of natural miscibility have not been determined. Apparently, however, these limits are not dependent upon their mode of formation, as the natural alloys are dominantly of magmatic origin. Platinum and palladium have continuous solidus-liquidus curves for binary alloys of each of these metals with gold, silver, copper, iron, nickel and cobalt, so that the base elements may readily constitute the dross, if they were originally present in the magma. Other variations, however, result from local conditions in the bedrock sources, so that the compositions of the natural alloys are markedly inconstant. The platinum minerals are likewise variable in composition, but the variations are much smaller than in the alloys.

Much less is known of the natural limits of miscibility of the hexagonal elements osmium and ruthenium with the other platinum metals and with the base metals. Melted mixtures of platinum or palladium with osmium or ruthenium show only partial solidusliquidus curves, which give place at some point to more than two phases. Natural alloys of osmium and ruthenium contain amounts of iridium that commonly exceed those of the osmium, and such alloys also contain small amounts of rhodium and platinum. The amount of platinum, however, may range upward to 15 percent, though a tenor as great as this suggests that the analysis was made on a mixed sample of the two alloys. Palladium is generally absent or present only as a trace. The solubilities of the base metals in these hexagonal alloys is apparently slight, as alloys of osmiridium invariably contain small amounts of dross. In general, the limits of these ranges in mis- 
cibility are different from those producible in the laboratory and have not yet been determined.

The separation of the platinum metals into soluble and insoluble fractions for analysis has already been mentioned. The insoluble fraction is reduced by repeated treatments with alkaline oxidizing fluxes, and thereafter is gotten into solution. For scientific comparisons, these two fractions may be separately analyzed, as was done for the writer in 1945 by Johnson, Matthey and Co. with a sample of platinum metals contributed by the Goodnews Bay Mining Co., Alaska. Ordinarily, however, the soluble and insoluble fractions are combined for final analysis. The presence of black sand that cannot entirely be removed from placer platinum metals has already been noted. These remaining minerals go into solution at the refineries, either in the aqua regia, or along with the insoluble fractions that are treated with fluxes. Hence invariably there is given, even in superior commercial analyses, a percentage of "impurities." This item includes the base metals that constitute the dross of the platinum alloys, the dross of any free gold that may be present, any lead shot, solder, or similar materials not recognized by the producer, and the base metals of the included black sand. Recent investigations have also shown that minute grains of chromite, chalcopyrite, and other minerals are intergrown in some of the natural platinum alloys. Thus in the platinum metals of the Goodnews Bay Mining Co., grains of chromite and chalcopyrite are clearly visible in polished sections at magnifications as low as 50 diameters. These facts lead to the conclusion that the true dross of natural platinum alloys, even in handpicked samples, is difficult to determine with precision.

Chemical analyses of the natural platinum alloys are of different classes, with different degrees of dependability. Analyses are divided by the writer into two general classes, which are designated as superior and inferior analyses. Superior analyses are considered to be those wherein the percentages of all the component platinum metals are determined, with or without the base metals of the dross. Exceedingly few such analyses are available of the platinum metals produced in foreign countries. Numerous analyses of this kind have been made by the U.S. Bureau of Standards, and one was made by the U.S. Geological Survey. Most assayers are incapable of making high-grade analyses of the platinum metals and alloys, and concerns which are capable of doing such analytical work do not always do so, as the cost may be prohibitive. Another reason why such analyses, if made, are not published is that it may be to the advantage of either the producer or the processor, or both, that such results should not be generally known. The best analyses available to the writer are those made by Johnson, Matthey and Co., Inc., of Malvern, Pa., for the Goodnews Bay Mining Co. of Alaska. Few other superior analyses appear in this report.

Inferior analyses include two general types. One type, which is the most prevalent, is essentially an analysis of only that part of the sample which dissolves in hot aqua regia. The insoluble fraction, whose total weight is known, is presented as osmium plus iridium, or perhaps as osmiridium. It commonly contains more iridium than osmium, as well as ruthenium and small amounts of platinum and rhodium. Therefore in such inferior analyses, the tenors of platinum, iridium, and rhodium are too low, and the tenor of ruthenium is neglected and rarely mentioned. Only the percentage of palladium is correct. The analyses of the platinum metals from Russia, because one part of the iridium is separately stated, whereas another part is reported as osmiridium, appear to be of this type; many other analyses in this report are of similar character.

A second type of inferior analysis is one wherein only the soluble platinum and palladium are reported and the soluble iridium and rhodium are added either to the platinum or to the insoluble fraction reported as iridium plus osmium. This procedure is common practice where the alloy contains only small amounts of iridium, osmium, ruthenium, and rhodium. Such analyses have little value, but they cannot be ignored, because they show at least the tenor in palladium and a minimum tenor in platinum. Examples of these are shown by the two mean analyses of Colombian platinum published by Singewald (1950, p. 174).

The problem thus arises how to present and interpret chemical analyses that are available in the literature. If, in addition to the percentages of some or all the platinum metals, the contents of copper, iron, and other base metals are specifically stated, the latter percentages cannot be ignored, and are stated as a part of the analysis with the implicit understanding that these tenors do not necessarily represent dross. If percentages of the base metals are not given, the gold (which is commonly free gold) is deleted, and the analysis is recomputed in terms of the platinum metals to total 100 percent. Even, however, if the tenors of the base metals are given, such recomputed analyses of the patinum metals alone serve a useful purpose in comparing different alloys with one another. 


\section{MINERALOGY}

The platinum metals occur in nature in two forms: first, as natural alloys and intergrowths of alloys, and second, as chemical compounds in which the platinum metals function as cations. The alloys are solid solutions and have as wide ranges in composition as their crystallography and other factors permit. The chemical compounds also have variable compositions but within smaller limits, as these are controlled by substituions of cations and anions with comparable radii. Wright and Fleischer (1965, p. A5-A6) have tabulated as compounds, or mineral species, the platinum metals known to be chemically combined with oxygen, sulfur, arsenic, antimony, bismuth, tin, or tellurium, if these elements function as anions. Recognizing, however, the uncertainty that exists in a definite classification of the platinum metals, they have tabulated all nonminerals as "alloys and intermediate compounds." The tabulation in this report is twofold, comprising alloys and minerals, with a reservation that a few of the socalled alloys may be partly or wholly minerals and vice versa. Moreover, in listing the alloys, preference is given to terms that indicate mixtures and intergrowths of platinum metals or alloys, as opposed to terms ending in "ite," which connote platinum minerals.

\section{NATURAL ALLOYS OF PLATINUM MLETALS}

The native platinum metals, found mainly in placer deposits, consist generally of two principal alloys, which occur either separately or intergrown with one another. These alloys are designated commercially and generically as "platinum" and "osmiridium." Platinum consists dominantly of that metal, but includes invariably the other five metals in variable amounts. Osmiridium consists dominantly of iridium and osmium, but includes also the metals ruthenium, rhodium, and platinum.

Samples of the platinum metals taken from placers are heterogeneous for a number of reasons. First, the two alloys do not have constant compositions, but instead vary from one site in bedrock to another. Second, the proportions of one alloy to another vary from place to place, and if they are intergrown, as they commonly are, the ratios of the two alloys in grains and nuggets are inconstant. Third, it is commonplace that very minute grains of one alloy, measurable perhaps in microns, may be present in another, and this is one reason why it is almost impossible to obtain pure samples of either alloy for chemical analysis. Fourth, platinum-bearing minerals may also be included; in fact, laurite has been found in one of the alloys of the platinum metals in the Goodnews
Bay district. Fifth, chromite is commonly either attached to or intergrown with the platinum alloys, and there are also minute inclusions of base minerals, wherein iron and copper are the principal cations, as exemplified by chalcopyrite. And finally, metallic iron and copper are invariably alloyed with the platinum metals, to form the dross. Bulk samples of the platinum metals recovered from placers therefore necessarily contain variable proportions of the six platinum elements, and chemical analyses, even superior analyses, have a limited value in deriving scientific conclusions regarding the compositions and interrelations of the alloys. Such analyses, however, may lead to important deductions relating to the origin and formation of the placers, and they are, of course, indispensable for commercial valuation of the platinum metals.

It is virtually impossible, for the reasons stated, to obtain pure samples of either of the two alloys, and the closest approximations appear to be in their electromagnetic separations. Osmium, iridium, and ruthenium have small magnetic susceptibilities, as is evident from table 3; osmiridium, composed mainly of these three elements, likewise has a low paramagnetism. The separation of a placer sample in an intense magnetic field yields one product that is mainly osmiridum, though minute intergrowths and inclusions of the principal alloy may also be present. Naturally, this method is more practicable if the sample is first sieved, and grains of -200 mesh are selected for the electromagnetic separation.

It follows, from the foregoing considerations, that specific mineralogical names of alloys, even of a single purified alloy, are not warranted, as an indefinite number of such terms could be applied. Nevertheless, numerous such designations have been used, according to the ideas of different writers. The better known of these names are shown in table 6 , even though they include duplications and improper designations, and many of them do not conform to the definition of a mineral species. The six platinum metals are not specifically tabulated, as they do not occur in nature free of one another. The names platinum and palladium are used, however, as generic terms. It may be added that gold should also be used as a generic term, as pure gold, free of silver and dross, is not present in nature.

The names osmiridium and iridosmium have been used by Palache, Berman, and Frondel (1944, p. 112) with meanings the reverse of those given in the preceding table. This has led to confusion, as the reader may be uncertain of the meaning intended by the writer. The products from the Witwatersrand and from Tasmania are alloys that contain more osmium 


\section{TABLE 6.-Alloys of platinum metals}

Platinum (generic term):

Cuproplatinum, cupric platinum.

Ferroplatinum. Ferric platinum with 10-30 percent Fe.

Nickel platinum, nickelic platinum.

Noril'skite, containing $\mathrm{Pt}, \mathrm{Pd}, \mathrm{Ni}, \mathrm{Fe}$, and $\mathrm{Cu}$.

Palladiplatinum, palladic platinum. $\mathrm{Pd}=\mathrm{Pt}$, approximately. Platinic iron.

Platiniridium, platinic iridium, avaite.

Polyxene. Platinum with less than 10 percent $\mathrm{Fe}$, and therefore a synonym of platinum.

Rhodic platinum.

Stannic platinum, stannoplatinite.

Unnamed alloys described by Genkin (1959) and Borovskii, Deev, and Marchukova (1959).

A. Contains Pt, Sn, Ir, Pd, and Fe.

B. Contains Pt, Pd, Sn, and Ir.

C. Contains $\mathrm{Pt}, \mathrm{Fe}, \mathrm{Ir}, \mathrm{Ni}, \mathrm{Cu}$, and $\mathrm{Ag}$.

Palladium (generic term):

Allopalladium, eugenesite. Contains $\mathrm{Pd}, \mathrm{Pt}, \mathrm{Ru}$, and $\mathrm{Cu}$, and traces of other elements.

Platinum amalgam, potarite. $\mathrm{PdHg}$ or $\mathrm{Pd}_{3} \mathrm{Hg}_{2}$.

Unnamed alloy described by Genkin (1959) and Borovskii, Deev, and Marchukova (1959).

D. Contains $\mathrm{Pd}, \mathrm{Pb}$, and $\mathrm{Ag}$.

Osmiridium, (Ir $>\mathrm{Os})$ :

Auric osmiridium, aurosmirid, aurosmide. Contains up to 19 percent Au.

Platinic osmiridium, platinosmiridium.

Rhodic osmiridium, rhodosmiridium.

Ruthenic osmiridium, ruthenosmiridium. Contains up to 21 percent ruthenium.

Iridosmium, iridosmine $(\mathrm{Ir}<\mathrm{Os})$ :

Osmite, synonym of iridosmine.

Platinic iridosmium, platiniridosmine.

Rhodic iridosmium, rhodiridosmine.

Ruthenic iridosmium, rutheniridosmine.

Nevyanskite (Ir 50-80 percent):

Varieties of nevyanskite, according to tenors of the other platinum metals.

Siserskite, sisserskite, sysertskite, (Ir 20-50 percent):

Varieties of siserskite, according to tenors of the other platinum metals.

Alloys of gold and platinum metals:

Platinic gold.

Iridic gold.

Rhodic gold, rhodite. Contains up to 43 percent rhodium

Palladic gold, porpezite. Contains up to 10 percent palladium.

than iridium, and are therefore properly called iridosmine, if use is made of that term. A commercial designation is needed, however, for alloys consisting dominantly of iridium and osmium, regardless of the relative proportions of these two metals. For this purpose, the writer uses the term "osmiridium," because the amount of iridium is generally greater than that of osmium, but for scientific descriptions, both osmiridium and iridosmine are employed.

The terms "osmiridium" and "iridosmine" are not necessarily correlative with "nevyanskite" and "siser- skite," because the numerical definitions of the two latter terms do not state whether they refer to analyses with dross or to analyses recomputed free of dross. Without this refinement, an alloy called nevyanskite may in fact be siserskite and vice versa. These names ending in "ite" are also objectionable because they suggest the definite compositions of minerals, whereas they are in fact alloys with widely divergent compositions. Osmiridium and iridosmine are preferable terms.

\section{CHEMICAL COMPOUNDS OF PLATINUM METALS}

The platinum metals also occur as chemical compounds, to which specific names have properly been applied. The platinum minerals may also include more or less copper, lead, tin, nickel and cobalt, and it is inferred that these elements substitute as cations for the platinum metals. If iron and chromium are reported, it is generally assumed that they are impurities resulting from an admixture with traces of other minerals, and even nickel and cobalt may sometimes belong in this category. The common base-forming elements are arsenic, antimony, bismuth, sulfur, tellurium, oxygen, and possibly other anions, such as selenium, but tin and lead may also function as anions instead of cations. The absence of a base-forming element indicates an alloy rather than a mineral, but as some elements may be either acid forming or base forming, it is sometimes difficult to decide whether certain combinations of elements represent alloys or minerals. A low percentage of tin or lead, however, suggests that these elements are present as cations.

The platinum minerals differ from the platinum alloys in one important respect. The principal platinum alloy, designated generically as platinum, contains generally all six of the platinum metals, though osmium and ruthenium may be present only in small amounts. Osmiridium contains five of the platinum metals, and by careful analysis, palladium may also be identified. The platinum minerals, on the other hand, contain fewer of the platinum metals, and it has not been proven that all of them are ever present.

Numerous platinum minerals have been discovered in recent years, notably since 1958. The principal investigators and discoverers, as shown in the accompanying bibliography, were J. E. Hawley, A. D. Genkin, E. F. Stumpfl, N. N. Zhuravlev, O. E. Zvyagintsev, and their several collaborators. Genkin (1959) recognized eight platinum minerals in the ores of the Noril'sk district, northwestern Siberia, which were identified by Borovskii, Deev, and Marchukova. Three of these proved to be platinum, alloyed with iridium, iridium and iron, or palladium, and a fourth was pal- 
ladium, alloyed mainly with lead. The other four are listed as unnamed minerals. Stumpfl, in 1961, identified nine additional platinum minerals in the ores of the Driekop Mine, Transvaal, Republic of South
Africa, of which one was named geversite. The other eight are listed as unnamed minerals.

The platinum minerals, as now known, are tabulated in table 7.

TABLE 7.-Platinum minerals, named and unnamed.

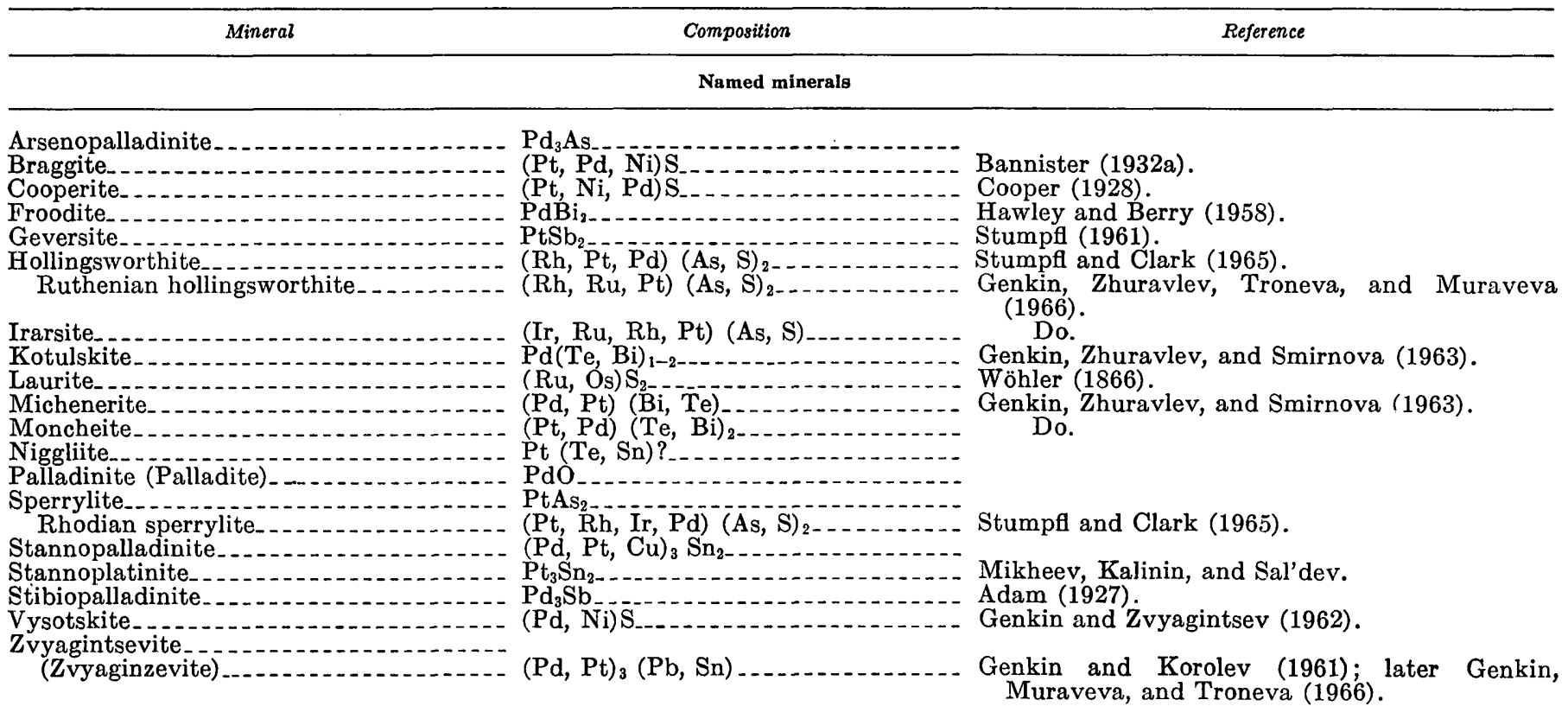

\begin{tabular}{|c|c|c|}
\hline \multicolumn{3}{|c|}{ Unnamed minerals } \\
\hline Composition & Reference & Composition \\
\hline $\begin{array}{l}\mathrm{PtBi}_{8} \text { (Not michenerite nor } \\
\text { moncheite) } \\
\mathrm{Pt}_{2} \mathrm{Sn}_{8} \\
(\mathrm{Pt}, \mathrm{Sn}) \mathrm{As}_{2} \\
(\mathrm{Pt}, \mathrm{Os}, \mathrm{Ru}) \mathrm{As}_{2} \\
\mathrm{PdS} \\
(\mathrm{Pt}, \mathrm{Ir}) \mathrm{As}_{2} \\
(\mathrm{Pt}, \mathrm{Ir}, \mathrm{Os}) \mathrm{As}_{4} \\
\mathrm{PtSb}\end{array}$ & $\begin{array}{l}\text { Hawley and Berry (1958). } \\
\text { Ramdohr (1960). } \\
\text { Genkin (1959), Borovskii, Deev, } \\
\text { and Marchukova (1959). } \\
\text { Do. } \\
\text { Do. } \\
\text { Stumpf (1961). } \\
\text { Do. } \\
\text { Do. }\end{array}$ & 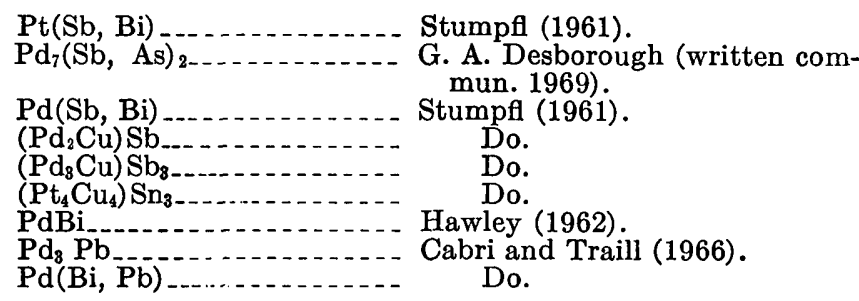 \\
\hline
\end{tabular}

Sperrylite, the most plentiful and widely distributed of the platinum minerals, is a tin-white brittle cubic mineral with a black streak, a hardness of $6-7$, and a specific gravity of 10.58. Is is highly resistant to atmospheric weathering. Sperrylite consists mainly of platinum chemically combined with arsenic, but contains also a small percentage of rhodium. Three analyses of sperrylite are known to the writer. These analyses, recomputed free of gangue and other impurities to total 100 percent, are shown in table 8 . The sperrylite from the Vermilion mine is very close to the theoretically computed values of platinum metals and arsenic.

Two spectrographic analyses of sperrylite (Lewis, 1950) from the Falconbridge mine in the Sudbury
TABLE 8.-Analyses, in percent, of sperrylite [N.D., no data]

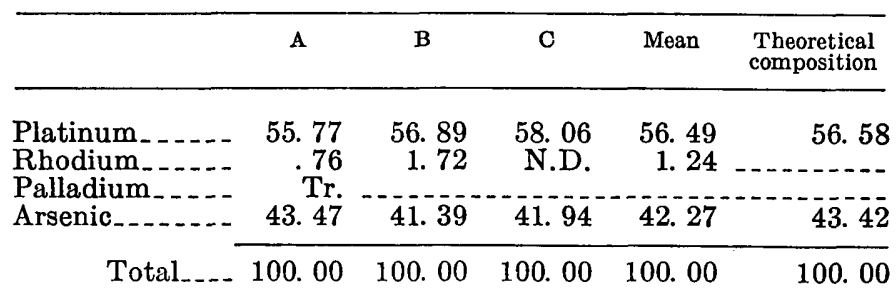

A. Vermilion mine, Sudbury district, Canada, mean of two analyses (Coleman, B. Tweefontein, Potgietersrust district, Republic of South Africa (Wagner, 19г9, C. Timpton Valley, Amur Province, southeastern Siberia (Quiring, 1962, p. 193).

district are given in table 9. The nickel and copper may be contaminants. The principal item of interest 
TABLE 9.-Spectrographic analyses of sperrylite from Falconbridge mine, Sudbury district, Ontario

[The symbols indicate intensity of spectral lines according to the following arbitrary scale: Mc, major constituent; Vs, very strong; S, strong; M, moderate; W, weak; $\mathrm{Tr}$, trace. Cited from Lewis, 1950

$S-57$

Platinum

Palladium

Arsenic _. Mc

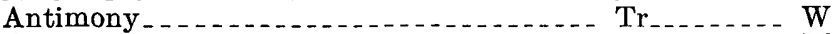

Gold........ W

Tin

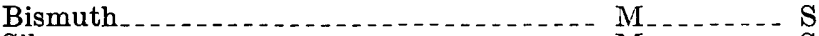

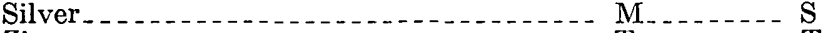

Zinc....... Tr.

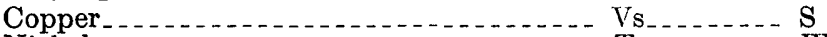

Nickel._...... Tr.

Iron

Silicon

Calcium

Cadmium.......... Tr.

in these analyses is the essential absence of palladium. This indicates that sperrylite is not a major source of palladium, and therefore that other palladium-bearing minerals are present in the ores of the Sudbury district, Ontario. Another noteworthy feature is the absence of rhodium in Lewis's two analyses, whereas rhodium appears in two of the analyses in table 8 .

Sperrylite, in addition to its cited occurrences, has also been reported from the Broken Hill district, New South Wales, Australia; from the Great Eastern mine in Clark County, Nev., from the Rambler and Centennial mines, Albany County, Wyo.; from certain tributaries of the Little Tennessee River, Macon County, N.C., and from other localities.

Cooperite, braggite, laurite, potarite, allopalladium, palladinite, stibiopalladinite, and niggliite are little known platinum minerals. Cooperite, braggite, and stibiopalladinite have been described from the Transvaal, Republic of South Africa. Laurite also occurs in the Transvaal and in Siberia but was first discovered in placer sands along the foothills of the Bobaris Mountains in Southeast Borneo. It later was reported from Colombia and Oregon. Potarite was described first from Guyana (formerly British Guiana), and was reported to be a chemical combination of palladium and mercury, but is classified in this report as a palladium amalgam. Allopalladium (eugenesite) is also included as an alloy. A surficial coating on a porpezite from Brazil was called palladinite and was assumed to be PdO, but no analysis is recorded. Niggliite is a rare mineral that was first found near Insizwa, East Griqualand, Republic of South Africa, about 300 miles south of Johannesburg. The other platinum minerals that are listed have been dis- covered in recent years and have been described in papers cited in the accompanying bibliography.

The list of platinum minerals presented above indicates that palladium is more prevalent than platinum in mineral compounds. This is expectable, as palladium is much less resistant to acid and alkali solvents than the other platinum metals. A large part of the palladium recovered at Sudbury and in the Transvaal is believed to occur as discrete minerals associated with the sulfides of the basic and ultrabasic host rocks. Mention should also be made of the fact that some of the platinum metals occur as atomic replacements of elements in the various ore minerals, and even in rock-forming minerals such as peridotite, perknite, gabbro, and their variants. Analyses of pyrrhotite, pentlandite, chalcopyrite, bornite, chromite, columbite, cassiterite, stannite, molybdenite, galena, freibergite sphalerite, sylvanite, hessite, and other minerals show that small amounts of the platinum metals may be present, if the atomic radii of the cations are not too different. The platinum metals may also occur as interstitial solid solutions in various minerals and ores.

\section{PLATINUM DEPOSITS}

\section{DISTRIBUTION}

The platinum metals have been found as natural alloys in many countries, notably in the Russian Urals, in Colombia, and in Alaska, but few other countries have had significant productions. Platinum lodes are uncommon, yet the bulk of the world's production is now coming from such deposits. The major sources are in the Union of Soviet Socialist Republics, in the Republic of South Africa, and in Canada; and the ores from these countries are described in considerable detail. The gold-platinum placers of Colombia have not been adequately described, but owing to their historical significance, they are treated as fully as the available data permit. The placers of the Goodnews Bay district, Alaska, are described in more detail than their size and production appear to warrant, for the following reasons. First, they are the only commercial platinum deposits in the United States, and are therefore of national importance; second, more statistical and genetic data on these placers are available than for any similar deposits elsewhere in the world; and third, an earlier report by the writer (1940) is now outdated and requires partial revision. The lithified placers of the Witwatersrand, Republic of South Africa, are given more attention than their production would appear to justify, because they are the world's principal source of osmiridium. Deposits that 
are small producers of the platinum metals, and others $\mid$ appears to warrant. Nonproductive deposits in the that were formerly productive but are now exhausted, United States are given more attention than similar are described in such detail as their scientific interest deposits in foreign countries.

TABIE 10.-Distribution of platinum metals

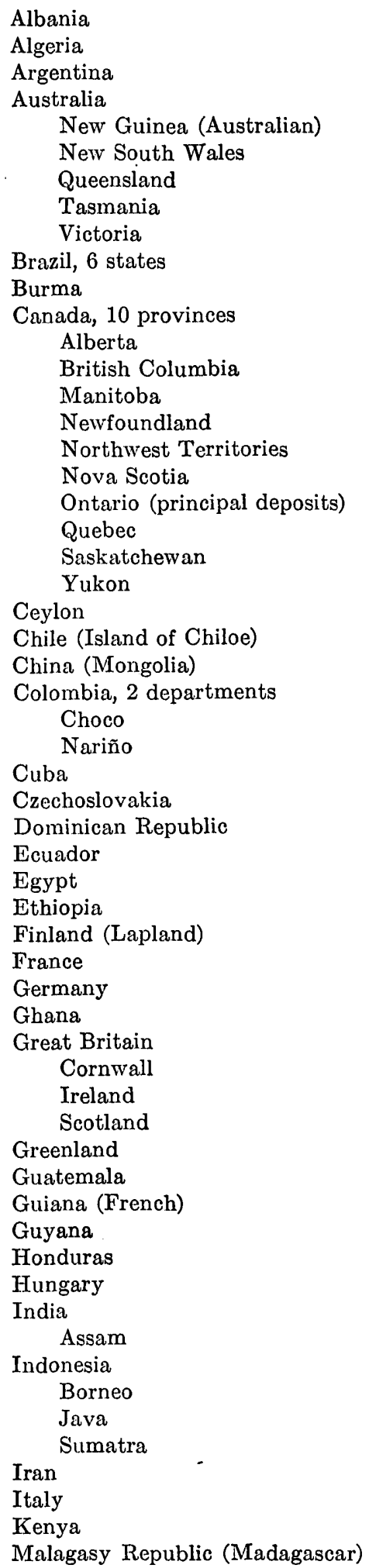

Malawi (formerly Nyasaland)

Mexico

New Caledonia

New Guinea

Papua

Territory of New Guinea

New Zealand

Norway

Panama

Peru

Philippine Islands

Portugal

Puerto Rico

Republic of the Congo

Katanga

Republic of South Africa

Cape of Good Hope Province

Orange Free State

Transvaal

Rhodesia

Romania

Sierra Leone

Somali Republic

Spain

Surinam

Sweden

Union of Soviet Socialist Republics

Noril'sk district

Petsamo district

Ural Mountains

Other districts

United States (12 States)

Alaska

Goodnews Bay district

Twenty-one other localities

Arizona, 3 counties

Arkansas

California, 34 counties

Colorado, 5 counties

Delaware

Georgia

Idaho, 8 counties

Maryland (Baltimore County)

Missouri

Montana, 5 counties

Nevada, 3 counties

New Mexico

New York

North Carolina, 3 counties

Oregon, 13 counties

Pennsylvania

South Dakota

Texas

Utah, 2 counties

Washington, 6 countíes

Wyoming, 3 counties

Venezuela 
Platinum metals have been found in 22 States of the United States, but only Alaska has become a major producer. In California and Oregon, platinum has been recovered in relatively small amounts as a byproduct of gold placer mining, and in several of the Rocky Mountain States, small gold-platinum or copper-platinum lodes have been mined, generally without a profit. Few of the occurrences of platinum metals in the United States merit description, but because such deposits exist in this country, all the principal ones are more fully described than similar deposits would be in foreign countries.

The principal countries in which platinum metals have been found are listed alphabetically in table 10, but most of these occurrences are so rare or freakish that they require no description in this report.

Spectrographic research has greatly multiplied the known habitats of the platinum metals. In fact, traces of these elements in rocks and minerals are becoming so commonplace that it is difficult to learn and tabulate all the new occurrences. Minerals and rocks that contain traces of the platinum metals have been tabulated by Wright and Fleischer (1965, p. A9 and A13). The platinum metals also occur in some meteorites and in the gases surrounding the sun, and they have been identified both in marine organisms and in sea water.

\section{CLASSIFICATION}

The platinum metals occur in workable deposits mainly as platinum minerals in nickel-copper and copper lodes and as platinum alloys in placers, but they occur also in other environments that are of more scientific than economic interest. The principal workable lodes are in Ontario and Manitoba, Canada, in the central Transvaal, Republic of South Africa, and in several areas of northwestern Siberia, U.S.S.R. To these should be added the lithified placers of the Witwatersrand, Republic of South Africa. Most of the workable lodes are characterized by platinum and palladium minerals, but some of them, notably in the Transvaal, also yield small amounts of the native metals or alloys.

\section{LODES}

The platinum metals occur as lodes in several different environments. The more significant deposits are related to the basic or ultrabasic rocks, but these metals are also found in ores that are related to granitic rocks, as shown in the following classification:

\section{CLASSIFICATION OF PLATINUM LODES}

A.-Platinum-bearing nickel-copper, copper, or copper-cobalt sulfides that are related genetically to basic or ultrabasic rocks, commonly the former, but are not magmatically segregated ores. The workable lodes occur principally as secondary concentrations of ore minerals rather than as magmatic minerals in situ, though the secondary ores appear to grade into disseminated ore minerals in the associated igneous rocks. The ore bodies occur either along the contact of the basic intrusives with country rock, or at variable distances up to $\mathbf{5}$ miles from the basic intrusives. These ores may or may not be associated with igneous rocks, of which some are considered to be related genetically to the parent basic rocks. By some geologists, the sulfides of these secondary deposits are thought to have originated as immiscible fluids of magmatic character; by others, these sulfides are considered to be epigenetic hydrothermal deposits. The ores of the Sudbury district, Ontario, exemplify such deposits. Native platinum metals or their alloys are commonly absent from deposits of this type.

B.-Platinum-bearing nickel-copper ores that are magmatically disseminated or concentrated in gabbroic and ultrabasic rocks. Pyroxenite and anorthosite the principal source rocks are commonly associated with norite and all of these may have the outlines of dikes, sills, pipes, lenses, or schlieren. These rocks are petrographically homogeneous along their major structures for long distances but they vary locally and produce layers and lenses of peridotite and chromite. The platinum metals occur mainly in sperrylite, cooperite, and other platinum and palladium minerals, but smaller amounts of the native platinum metals or alloys are commonly present. The platinum minerals occur in the sulfides and in lesser amounts in the silicates and may be sufficiently plentiful to constitute the principal value of the ores, with byproducts of nickel copper, and other metals. The Merensky zone, in the Bushveld igneous complex of the Transvaal, illustrates this type of deposit. The ratios of platinum to palladium are significantly greater in the ores of class B than in those of class A.

C.-Native alloys of the platinum metals that are magmatically disseminated in peridotites, less commonly in perknites, and rarely in gabbros. If concentrated, they are commonly intergrown with chromite. Most of these deposits are in dunites, which range in composition from hortonolite dunite to olivine dunite. The dunites at some localities may be partly or wholly altered to serpentinite. The platiniferous hortonolite or iron-rich dunites are exemplified by the Onverwacht and Mooiheep properties in the Bushveld igneous complex of the Transvaal. Platiniferous-dunites, perknites, and their alteration products are the sources of the Uralian placers; dunite and serpentinite are the sole sources of the placers of the Goodnews Bay dis- 
trict, Alaska; and so far as known, similar peridotites and perknites are the sources of most placers that are known in the world. Platinum and osmiridium lodes have been discovered in dunite or serpentinite, principally in the Urals and in South Africa, but generally they have proven to be either too small or too low grade for profitable mining. Some masses of chromite, however, have been found in dunite that had high tenors in the platinum metals.

D.-Platinum minerals or native platinum alloys in copper and related ores indigenous to contact metamorphic and other types of ore bodies, including vein systems.

E.-Native platinum metals in the gold ores of quartz veins and in other ores of free gold. Twentythree examples of such deposits are listed on page 98 .

F.-Platinum-bearing meteorites.

G.-Secondary platinum metals:

1. Recovered in purification of blister copper and copper mattes that produced on a large scale.

2. Recovered at the U.S. Mint and other mints, in the refining of metallic gold. The U.S. Mints make no payment to the producers of gold bullion for such platinum metals, claiming them as seignorage.

3. Recovered from industrial wastes and from jewelry.

\section{PLACERS}

Platinum placers consist of alluvial deposits that contain in workable amounts the alloys of the six platinum metals, and it is worthy of note that no analagous deposits of platinum minerals have ever been found. The platinum metals occur commonly in two alloys of variable composition, of which one consists dominantly of platinum with varying amounts of the other five elements, whereas the other consists dominantly of iridium and osmium, less ruthenium, still smaller amounts of platinum and rhodium, and with little or no palladium. Much of the placer platinum consists of two intergrown or intermixed alloys, each of variable composition, as exemplified by the product recovered in the Goodnews Bay district and described on pages $84-87$.

Some of the alluvial platinum comes from placers that yield both gold and platinum. The stream placers of Colombia and of California, later to be described, are excellent examples. Commonly the gold and platinum are separate alloys, one of gold and silver and the other of five or six platinum metals. This fact is not generally clarified by analyses of placer platinum, as small amounts of gold are reported merely as a part of the contained precious metals. Hence such analyses, in order to be comparable with others which show no gold, have to be recomputed free of gold as well as free of "impurities." Examples will later be given, however, of placer gold with which small amounts of the platinum metals are alloyed.

The densities of the platinum alloys found in placers and the sizes of their grains are generally similar to those of alluvial gold; hence, the geologic classification of platinum placers is exactly like that of the gold placers, as heretofore used by the writer:

A. Residual and eluvial placers.

B. Stream placers.

1. Present stream valleys.

2. Older stream valleys.

a. Terrace deposits.

b. Buried deposits.

C. Beach placers.

1. Present beaches.

2. Ancient beaches.

a. Elevated beach deposits.

b. Buried beach deposits.

D. Deltaic and outwash deposits.

E. Glaciofluvial (glaciofluviatile) deposits.

F. Aeolian deposits.

G. Lithified placers.

Placers of the platinum metals are commonly derived from dunite or serpentinite, less commonly perknite, in which these metals are sparsely and irregularly distributed. In nonglaciated regions, it may be inferred that the original lodes could be discovered by tracing the alluvial deposits upstream. Commonly the general country rock may thus be recognized, but workable lodes can rarely be located. This may result from one or more of the three following causes:

1. The original rocks from which the placers were derived may have been completely eroded, so that no platiniferous source rocks remain in the area.

2. The present country rock may be platiniferous, but may represent the uneroded low-grade roots of lodes that were much richer in their apical horizons.

3. All the original source rocks may have been of extremely low grade, and the placers may have been concentrated from such sources over a very long period of time. Under such circumstances, representative source rocks, even if preserved, would not constitute workable lodes and are not likely to be discovered.

The formation of placers is possible under any of these conditions. But workable lodes can rarely be located in placer fields, and it is therefore concluded that the platinum metals in placers have been concen- 
trated generally from source rocks wherein these metals were sparsely and widely disseminated.

Heavy metals, such as platinum or gold, rarely migrate far downstream from their bedrock sources, unless they are so fine grained as to be moved by swift water or floated by surface tension. Flour gold, for example, may move downstream for many miles, in fact to the ocean. Generally, however, ordinary detrital grains of platinum or gold work rapidly downward through alluvial deposits, and come to rest either near, on, or within bedrock. If the bedrock has a well-developed cleavage or fracture, the precious metals may penetrate 10 feet or more. Only very high water that cuts to bedrock, or rejuvenation of a stream, will again move these metals, and even under these conditions, their downstream migration is not great. Hence, excepting some special environment, such as glaciation, placers of the precious metals may be assumed to lie within a few miles of their bedrock sources. If placer paystreaks are very long, it may be suspected either that several bedrock or proximate sources are present in a valley, or that the metals have been distributed downstream by repeated lowering of the base level of erosion or as result of glaciation.

\section{CANADA}

\section{SOURCES AND PRODUCTION}

Native platinum and osmiridum appear to have been discovered in Canada by T. Sterry Hunt (1852, p. 120) in concentrates recovered from the placers on Rivière du Loup and Rivière des Plants, tributaries of Chavdiere River, in southern Quebec. Platinum metals were subsequently found in 10 of the 13 provinces of Canada, though only a few of these deposits are or have been significant producers. No workable lodes of native platinum metals are known to exist, but numerous platinum- and palladium-bearing basemetal lodes and platinum-bearing gold placers have been discovered. Platinum-bearing and palladiumbearing sulfides, mainly in nickel-copper lodes, have been located in Alberta, British Columbia, Manitoba, Newfoundland, Northwest Territories, Nova Scotia, Ontario, Quebec, Saskatchewan, and Yukon. The most important of these are the nickel-copper deposits of the Sudbury district, in south-central Ontario, and those of north-central Manitoba, though similar lodes in the other provinces may in the future yield considerable amounts of the platinum metals.

Alluvial deposits containing the platinum metals are known in the provinces of Alberta, British Columbia, Quebec, and Yukon. In earlier years, the Tulameen district of British Columbia was an impor- tant producer of alluvial platinum, but these placers are now considered to be worked out, though certain fluvial deposits of greater thickness may sometime be mined. Small amounts of the platinum metals have also been recovered in other Canadian provinces, mainly as a byproduct of the mining of gold lodes and placers.

The total production of platinum inetals from Canada for 1965 and 1966 came mainly from the Sudbury district, Ontario, but since 1962 has included also an output from the nickel-copper mine at Thompson, Manitoba, and lately a small output from a similar ore body near Lynn Lake, Manitoba, together with a minor byproduct from gold placers. The total production of platinum metals from all Canadian sources, up to and including 1966, has been about $11,440,000$ troy ounces, with a maximum annual output in 1960 of 483,604 ounces.

\section{ONTARIO \\ SUDBURY DISTRICT \\ DISCOVERY AND PRESENT MINING}

The basic rocks of the Sudbury area were first observed by A. P. Salter, a Canadian Government surveyor, in 1857; and Alexander Murray, of the Canadian Geological Survey, verified the presence of these rocks in the same year. Copper sulfides were discovered by Thomas Flanagan in a gossan outcrop west of Sudbury in 1883, along the right-of-way then being opened for the Canadian Pacific Railroad; and in the next few years, most of the larger ore deposits of the district were found. The production of nickel and copper began in 1887. The platinum metals are a byproduct of the production of nickel and copper in the Sudbury district. Other byproducts that are now recovered include selenium, tellurium, gold, silver, cobalt, and iron.

Platinum, in the form of platinum diarsenide (sperrylite) was discovered at the Vermilion mine, in the Sudbury district, in 1885 by F. L. Sperry, a chemist of the Canada Copper Co., and this mineral was described and named by H. L. Wells (1889). As early as 1900, platinum was isolated in the ores of the Mond Nickel Co., and some platinum metals were extracted in subsequent years by Johnson, Matthey and Co., Ltd., in London. According to the Imperial Institute $(1936$, p. 62$)$, the first recognized output from Canadian lodes was in 1919, when 25 ounces of platinum and 62 ounces of palladium were recovered.

The nickel-copper lodes of the Sudbury district are the principal sources of the platinum metals in Canada. These ores lie along or close to the margin of a synclinal basin of the basic igneous and overlying 
sedimentary rocks, situated in south-central Ontario about 50 miles north of Georgian Bay, an arm of Lake Huron. Sudbury, which lies along the southeastern side of this basin, is a city of 35,000 people, which is reached by the Canadian Pacific and Canadian National Railroads as well as by first-class highways. An airport is located at the east side of the basin.

The important operating mines lie along or a short distance outside the margins of this synclinal basin. Most of these are now owned and operated by two companies, the International Nickel Co. of Canada, Ltd., and the Falconbridge Nickel Mines, Ltd. The International Nickel Co. of Canada, Ltd. owns the Creighton, Frood-Stobie, Crean Hill, Garson, Levack, Murray, Clarabelle (opencut), MacLennan, Totten, Copper Cliff, Copper Cliff North, Coleman, Kirkwood, Little Stobie, Blezard, Evans, Vermilion, Worthington, Victoria, Whistle, Shepard, and other mines, of which the first nine were producers in 1965. This company has concentrators at Copper Cliff and Creighton; smelters at Copper Cliff and Port Colborne, Ontario, and at Clydock, Wales; and precious metal refineries at Copper Cliff and at Acton, England (Mond Nickel Co.). The International Nickel Co. of Canada, Ltd. produces about 90 percent of the platinum metals recovered annually in the Sudbury district.

The Falconbridge Nickel Mines, Ltd. owns the Falconbridge, Falconbridge East, Hardy, Onaping, Fecunis Lake, Mount Nickel, McKim, Longvac, Longvac South, Strathcona, Lockberry, and other mines, of which the first five were productive in 1965. This company owns a smelter at Falconbridge, and the nickelcopper mattes are sent to their refinery at Kristiansand, Norway, for separation of the metals. The slimes from this process are refined, and the platinum metals recovered by the Englehard Industries, Inc., of Newark, N.J.

\section{GENERAL GEOLOGY}

The general geology of the synclinal basin, along whose margins lie the platinum-bearing nickel-copper ores, is difficult to interpret, as is indicated by the large volume of conflicting geological reports listed in the bibliography (p. 102-112). The synclinal basin is subelliptical in two-dimensional outline, with a spoonshaped three-dimensional form, a length of about 37 miles, and a maximum width of about 17 miles. The direction of the major axis is about N. $65^{\circ} \mathrm{E}$. The rocks dip generally toward the center of the basin, but the basin is asymmetrical in that the dips are commonly steeper along its. southeast than along its northwest side. Locally, however, the steeper north- westerly dips along the southeast flank are reversed to the southeast. In detail, the structure is by no means simple, as the syncline, particularly along its southeast flank, is modified by minor folds and faulting. Surficially the central part of the basin shows low relief, but the igneous rocks that bound it cropout as low hills, which are designated locally as the north, east, south, and west ranges.

The igneous part of the basin consists of two peripheral sill-shaped masses of intrusive rocks, separated by a narrow transitional zone, with a total thickness estimated by Knight (1923) along the east range of about 8,300 feet. The lower mass of "norite" has a thickness of about 1,800 feet; the upper mass consists of micropegmatite or granophyre with a thickness of about 6,000 feet; and the transitional zone has a thickness of about 500 feet. Associated with the norite along its basal margin are quartz diorite and other intrusive rocks which are considered by Hawley $(1962$, p. 10) to be phases of the norite, though this interpretation is not universally accepted. The total relative thickness of the norite and the granophyre vary on the different ranges, as shown by the dips of the rocks and widths of the outcrops. Thus on the south range (southeast flank of the basin), the thickness of the two principal units appears to be less different than on the north range. The width of the total outcrop of the igneous rocks ranges from a minimum of $11 / 4$ miles on the north range to a maximum of $41 / 2$ miles on the south range. The average total width on the north range is 1.9 miles and on the south range is 3.1 miles. These igneous rocks that delimit the Sudbury basin are said by Canadian geologists to be of late Huronian (Animikie) age.

The younger rocks inside the four ranges forming the central part of the basin, comprise a group of tuffaceous and sedimentary rocks called the Whitewater series, which, according to Cooke (1948), Yates (1948), Thomson (1957a) and other Canadian geologists, consists of the Onaping tuff, the overlying Onwatin slate, and the superjacent Chelmsford sandstone. A basal member of the Onaping tuff is the Trout Creek conglomerate or agglomerate. The thickness of the Whitewater series, owing to lack of outcrops, is known only approximately, but the Onaping tuff has been estimated to have a thickness of 5,000 feet, and the two overlying formations are believed to have a combined thickness of 3,700 feet. The Whitewater series is considered to be of late Huronian (Keweenawan) age.

Older sedimentary and igneous rocks underlie the noritic and associated intrusives. The stratigraphic succession of these rocks has been given by Knight 
(1943), Cooke (1946), Yates (1948), and other Canadian geologists. According to these geologists, a group of sedimentary and igneous rocks, called the Sudbury or Timiskaming series, and believed to be of early Huronian age underlies the noritic irruptive. The formations of the Timiskaming series, named from top to bottom, are the Mississagi quartzite, the McKim graywacke and the Copper Cliff arkose, underlain by the Frood series. An ancient greenstone, originally of intrusive origin, overlies in places the Mississagi quartzite. These two formations, subjacent to the norite, are of importance in relation to the genesis of the nickelcopper lodes. The oldest rocks of this district, underlying the Frood series, compose the Stobie group, which consists of metamorphosed andesitic and basaltic lavas and quartzites.

The sequence above outlined is amplified by numerous intrusive rocks, notably by at least six types of granitic rocks. Two of these are granites, or granitic gneisses, that occur throughout the Sudbury series, and certain younger granitic rocks that intrude both the norite and the micropegmatite. Of special genetic interest is the quartz diorite that occurs at places along and near the contact between the norite and the underlying quartzite and greenstone.

\section{INTRUSIVE ROCKS}

The noritic rocks and associated intrusives, the overlying transition zone, and the micropegmatite at the top of this igneous sequence constitute what is known collectively as the "nickel irruptive" because they have been interpreted as related genetically to the nickelcopper ores. The distribution of the "nickel irruptive" is shown in figure 1. No general agreement exists, however, as to the mode of formation of the "nickel irruptive" nor as to its influence in the formation of the ore bodies. Bell (1891) was the first to recognize a closure of the igneous ring and the existence of the Sudbury basin. Walker $(1897,1935)$ conceived the idea that the "nickel irruptive" was a homogeneous intrusive which after its original placement was differentiated gravitatively into three units; Barlow (1904, 1906) corroborated this interpretation; and Coleman, in several reports $(1905,1907,1913,1916,1923)$, carried this hypothesis to its ultimate development. The hypothesis was also adopted by Adams, Kemp, Roberts, Longyear, and others. Along with the idea of differentiation by magmatic settling came the idea of enrichment of the nickel ores by gravitative action. This mode of ore genesis has now been abandoned, and along with this has come the interpretation that the norite and the micropegmatite were separate and distinct intrusives.

The basin was interpreted first as a subsiding lopolith and later as a synclinally folded lopolith. But it has also been maintained that a basin of subsidence existed before the intrusion, and similarly that synclinal folding occurred before the intrusion. No agreement exists in regard to these hypotheses of placement. A recent highly speculative hypothesis by Wilson (1956) envisages the irruptive as the part of a funnelshaped intrusive of which the bottom (concealed) consists of utrabasic rocks that underlie the norite. This seems to revert to the interpretation of magmatic differentiation by gravitative settling.

The micropegmatite consists generally of intergrowths of potash feldspar and quartz, arranged radially around plagioclase, commonly oligoclase. The mafic minerals are hornblende with less biotite, both much altered to epidote. The most siliceous part of the micropegmatite is not at its inner boundary on the east range, as earlier reported, but according to Knight (1923) near its basal part.

The norite has been studied petrographically by Phemister (1926), who concludes that this designation is a misnomer, because most of this intrusive contains little or no orthorhombic pyroxene. The common mafic mineral is hornblende, and though scme of this is secondary, there is no evidence that it was derived from hypersthene. The plagioclase is a zoned labradorite, and some of the rock contains quartz. The so-called norite appears to lie petrographically between a monzotonalite and a granogabbro, and might be called a hornblende quartz gabbro. A more specialized designation would be bojite. The norite is most basic not at its base, but somewhere above its medial zone, close to the overlying transition zone.

The quartz diorite, to which reference has been made, occurs sporadically at or near the base of the norite, without clean-cut contacts between those two rocks, but with well-defined contacts with the members of the Mississagi quartzite and associated greenstone. It appears from subsurface exploration to disappear downward in the adjacent country rocks, and this is used by Hawley (1962, p. 26) as one line of evidence that the quartz diorite is merely a phase of the norite. The quartz diorite is composed of plagioclase (andesine to labradorite), quartz, pyroxene, amphibole, biotite, and accessory minerals, mainly apatite. The mafic minerals are in various stages of alteration-the pyroxene to hornblende and the amphibole to shreds of tremolite and actinolite. The biotite is bleached. As a whole, however, this rock is less altered than the norite near its basal contact. 


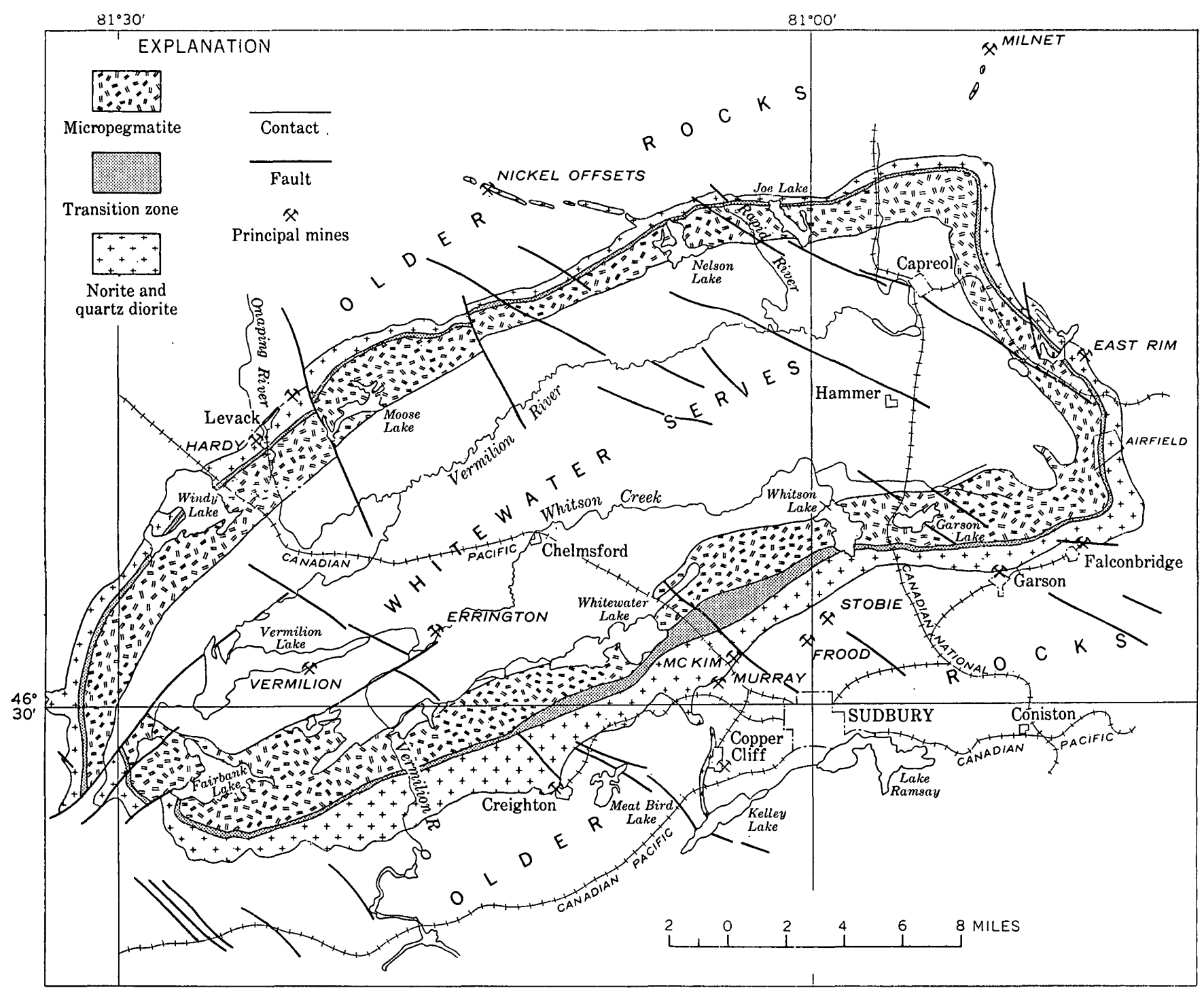

Figure 1.-Geologic map of "nickel irruptive," Sudbury district, Ontario. (Generalized from Geol. Soc. America, Toronto Field Trips Comm., 1953.)

ORE DEPOSITS

The nickel-copper ores occur along the north, south, and east ranges of the irruptive, but mainly along the south-southeast side. Most of the ore bodies are localized at two sites, one at or close to the basal contact of the norite with the underlying rocks and a second at distances up to 5 miles from the norite. These bodies are designated respectively as marginal and offset deposits. Some of the marginal deposits extend upward or laterally into the bounding norite, but very few lie entirely within the norite. The Falconbridge, Garson, Creighton, and Murray mines may be cited as examples of marginal deposits adjacent to norite, and the Levack mine as a marginal deposit that lies within but close to the base of the norite. The Copper Cliff, Worthington, and Frood-Stobie properties illustrate the offset lodes. A third type of deposit is represented by the Errington and Vermilion mines, where according to Thomson and others $(1957$, p. $85-86)$, the ore bodies are replacements of a chert-carbonate horizon that lies at the contact of the Onaping tuff and the overlying Onwatin slate.

A description of all the cited ore deposits and mines of the Sudbury district is obviously beyond the scope of this report; and only general relationships are warranted and offered. The ore bodies are generally irregular in outline, but where unfaulted are commonly lenticular with an orientation parallel to that of the norite, plunging therefore toward the center of the synclinal basin. Where faulting and minor folding occur, this general orientation may be reversed. The ores, according to Thomson and others (1957). lie 
within a variety of host-rocks, which include quartzite, greenstone, quartz diorite, gabbro, norite, granite, andesite, and breccias of these rocks. The principal structures which have been provided channelways for the ore solutions are faults, breccia zones, and less definite loci of shattering and brecciation. Regardless of the nature of the deposits and of the solutions that produced them, it is clear that the sulfide ores are secondary with regard to their present host rocks.

These deposits have been classified by Hawley (1962, p. 32-38) into five types, designated as disseminated, massive, immiscible-silicate-sulfide, breccia, and vein stringer ores, of which the breccia ores are the most important. The primary minerals of both marginal and offset deposits, according to Hawley (1962, p. 41-128), are pyrrhotite, pentlandite, chalcopyrite, and cubanite, and the minor ore minerals are magnetite, ilmenite and pyrite. The rarer ore minerals comprise gersdorffite, niccolite, maucherite, heazlewoodite, bornite, valleriite, sphalerite, stannite, violarite, marcasite, native gold, silver, bismuth, and copper, tetradymite, hessite, chalcocite, bismuthinite, nickelferous pyrite, parkerite, schapbachite, galena, molybdenite, tetrahedrite, smalltite, danaite, and hematite. The secondary supergene ore minerals include millerite, marcasite, limonite, chalcanthite, melanterite, morenosite, annabergite, and erythrite. The principal carriers of the platinum metals are pyrrhotite, pentlandite, and chalcopyrite, though these metals are known in smaller amounts in cubanite and pyrite and may also be present in some of the rarer ore minerals. The platinum-bearing minerals, intergrown with or included in the ore carriers, include sperrylite, michenerite, froodite, and an unnamed palladium bismuthide, but work is in progress that undoubtedly will result in the discovery of other platinum and palladium minerals. The platinum metals also exist as molecular replacements within the cited carrier minerals. No native platinum metals or alloys exist in these ores.

The ores at the Errington and Vermilion mines are quite different from those of the marginal and offset deposits. The ore minerals at the Errington mine, according to Thomson and others $(1957$, p. 85$)$, consist of fine-grained pyrite, sphalerite, chalcopyrite, pyrrhotite, and galena in a carbonate matrix; and the metallic products are zinc, lead, and copper, with small amounts of gold and silver and mere traces of nickel. The ore deposit and minerals of the Vermilion mine are generally similar, though the geologic environment is much more complex; but this deposit, where sperrylite was first discovered, had a high tenor in gold and platinum.
The gensis of the Sudbury deposits has not been settled, but three principal hypotheses have been formulated.

1. The ores are magmatic sulfides that originated in the norite and were segregated petrographically or gravitatively at the base of the irruptive, whence they were distributed along the contact and in zones of fracturing.

2. The ores resulted from the injection of a magmatic sulfide melt along channelways in the norite and adjacent country rock, after the solidification or partial solidification of the norite. The ore deposits resulting from these magmatic injections are designated by Hawley (1962, p. 148-150) as primary ores, because they are considered to be of magmatic origin, but in relation to their host rocks, such deposits are secondary and nonsyngenetic.

3. The ores are epigenetic and probably hydrothermal, resulting from the introduction of sulfides into the norite and adjacent country rock. The ore-bearing solutions may have come from norite, quartz diorite, or from deep-seated sources of unknown origin.

Knight (1923) has studied the norite throughout its thickness of 8,300 feet on the eastern nickel range and has found that the most basic part of the norite is not along its eastern edge but from 1,500 to 2,000 feet higher in the sequence. Also the most silicic part of the micropegmatite is not along its western edge but from 3,400 to 4,300 feet lower in the sequence. And finally, the country rock adjacent to the ore deposits may contain as much or more sulfides than the bounding norite. Hence, the first hypothesis no longer appears to be acceptable. The second hypothesis has been favored by many of the earlier writers and by Hawley in 1962 . But the secondary nature of the sulfide ores and other lines of collateral evidence have led Dickson (1905), Knight (1917, 1920, 1923), Wandke and Hoffman (1924), Phemister (1926, 1937, 1956), Lockhead (1955), and other geologists to believe that the marginal and offset ore deposits are of epigenetic and hydrothermal origin. Thompson (1960) stated his belief that not only all the massive sulfides of the Sudbury district, but also the disseminated ores associated with them are of hydrothermal origin. The opinion is based upon the following criteria:

1. Spatial relationship of sulfide bodies to secondary structures, such as faults, folds, and fractures.

2. Wallrock alteration.

3. Well-defined paragenetic sequences of mineralization.

4. Different generations of sulfides. 
5. Considerable variations in sulfide and metal content throughout the mineralized zones.

6. Irregular shape of mineralized bodies.

\section{PLATINUM METALS}

The tenors of all metals in the Sudbury ores are known to be variable, and maximum and minimum values for different mines are not commonly published. According to several authorities quoted by Hawley $(1962$, p. 116$)$, the $\mathrm{Ni}: \mathrm{Cu}$ ratio ranges from $1: 0.5$ to $1: 3$, but for the total production of the period 1947-57, this ratio was $1: 0.8$. The ratios pyrrhotite :chalcopyrite: pentlandite are estimated to be approximately $70: 15: 15$.

The tenors of the platinum metals, which depend upon the absolute and relative amounts of the sulfides, are correspondingly indefinite. In ores that contained 5 percent nickel and copper, O'Neill and Gunning (1934, p. 66), have shown a mean tenor for the period 191215 of 0.014 ounce platinum metals per ton. Allen (1961, p. 138) states that the average value is 0.02 ounce per ton. Hawley $(1962$, p. 122) presents a mean tenor of 0.019 to 0.026 ounce per ton-a value taken from a statement by the Ontario Department of Mines, based upon the recovery of platinum metals from the Sudbury ores for the period 1947-57.

The nickel-copper ores at the different mines in the Sudbury district have different tenors in the platinum metals, so that the output of the platinum metals is not necessarily related to the output of the base metals. Thus by mining ores of higher or lower content of platinum, the output of the platinum metals may be increased or decreased without altering materially the production of nickel and copper. It is generally known that the tenor of platinum metals is higher in the offset deposits than in the marginal deposits.

The relative amounts of the different platinum metals in the Sudbury ores is also indefinite, but the production of these metals over a long period of years gives an average ratio for platinum and palladium and some data on iridium, ruthenium, and rhodium. Among the available estimates are those by Rogers and Young (1929) for the period 1923-27, O'Neill and Gunning (1934) for the period 1923-32, corrected to apply only to the Sudbury ores, Tremblay (1946) for the period 1937-41, and Hawley (1962) for the period 1947-57. These are presented in table 11.

The indefinite character of these percentages is emphasized by another set of figures, quoted by Hawley $(1962$, p. 122) that apply to the mines of the Falconbridge Nickel Mines, Ltd. These, in percentages, are platinum 36.6 , iridium 4.7 , ruthenium 9.9 , rhodium 8.8 , and palladium 40.0 . Here the ratio of platinum to pal-

\begin{tabular}{|c|c|c|c|}
\hline & Platinum & Palladium & Others \\
\hline $\begin{array}{l}\text { Rogers and Young (1929) } \\
\text { O'Neill and Gunning }(1934) \\
\text { Tremblay (1946) } \\
\text { Hawley (1962) }\end{array}$ & $\begin{array}{l}\text { 49. } 02 \\
47.99 \\
54.26 \\
46.00\end{array}$ & $\begin{array}{l}48.97 \\
45.42 \\
41.65 \\
41.00\end{array}$ & $\begin{array}{r}\text { 2. } 01 \\
\text { 6. } 59 \\
\text { 4. } 09 \\
\text { 13. } 00\end{array}$ \\
\hline
\end{tabular}

ladium is approximately $1: 1.1$, which is the reverse of the four tenors shown above.

For recent years, much confidence should be placed on Hawley's estimate, which is based on productive data over a period of 10 years. Independent figures obtained by the writer from the U.S. Munitions Board and the War Production Board during World War II indicate that in general the amount of platinum exceeds that of palladium by 3 to 5 percent and that rhodium had the highest tenor of the minor elements, ranging from 8 to 12 percent. The tenor of ruthenium ranged from 2 to 3 percent and that of iridium from 1 to 2 percent. Osmium is rarely mentioned as one of the recovered elements, because it probably is lost by sublimation during smelting.

The amounts of the precious metals in the ores of the Falconbridge mine are well shown in a paper by Lewis (1957), wherein are given the results of numerous chemical analyses of crude ores, pyrrhotite concentrates, and flotation concentrates. Neglecting the gold and silver in these determinations and recomputing to 100 percent, the mean tenors of the platinum metals are shown in table 12.

TABLE 12.-Platinum metals, in percent, in ores from Falconbridge mine, Sudbury district

Platinum Rhodium Palladium

Crude ores_................... $54.1 \quad 14.2 \quad 31.7$

Pyrrhotite concentrates......

Flotation concentrates.......

The percentages of platinum and palladium in the flotation concentrates agree fairly well with those heretofore presented and confirm the prevalence of platinum over palladium. The percentage of rhodium in the flotation concentrates agrees with the independent figures cited on page 24 . The high percentage of rhodium in the pyrrhotite concentrates suggests a possible concentration of this metal in pyrrhotite; in any event it emphasizes the differences of tenors in different host minerals.

Spectrographic data have been presented by Hawley, Lewis, and Wark (1951, p. 158) on the tenors of the platinum metals in the ore minerals pyrrhotite, chal- 
copyrite, pentlandite, and pyrite, together with tenors from the mixed arsenides maucherite, niccolite, and gersdorffite. These are shown in table 13.

TABLE 13.-Spectrographic data, in ounces per ton, on platinum and palladium in ore minerals, Sudbury district

\begin{tabular}{|c|c|c|c|}
\hline & Platinum & Palladium & Both \\
\hline $\begin{array}{l}\text { Pyrrhotite } \\
\text { Chalcopyrite } \\
\text { Pentlandite } \\
\text { Pyrite } \\
\text { Maucherite }\end{array}$ & $\begin{array}{l}0.148 \\
.078 \\
.935 \\
.011 \\
\text { Tr. }\end{array}$ & $\begin{array}{r}0.472 \\
.735 \\
.440 \\
.009 \\
7.223\end{array}$ & $\begin{array}{r}0.620 \\
.813 \\
1.375 \\
.020 \\
7.223\end{array}$ \\
\hline
\end{tabular}

More complete spectrographic data, however, have recently been published by Hawley (1962, p. 124-125). These are of particular interest in that they differentiate between the average run of ores and the ores from an offset deposit. Noteworthy are the higher tenors in platinum metals from an offset deposits. Changed slightly, so that platinum, rhodium, and palladium sum to 100 percent, these data are presented in tables 14 and 15.

TABLE 14.-Mean tenors of platinum metals, in percent, in common ore minerals, Sudbury district

Pt $\quad$ Rh $\quad$ Pd \begin{tabular}{c}
$\begin{array}{c}\text { Total metals } \\
\text { (ounces per } \\
\text { ton) }\end{array}$ \\
\hline
\end{tabular}

Pyrrhotite (mean of 37 samples)_ $57.2 \quad 11.1 \quad 31.7$

0.035 Chalcopyrite (mean of 7

samples)

Pentlandite (mean of 3 samples) - 33. 0

Pyrite (mean of 3 samples) _.... 56. 2

.981 .4

7. $5 \quad 59.5$

.224

2.5 41. 3

the ounces of platinum metals respectively in pyrrhotite, chalcopyrite, and pentlandite are shown in table 16.

TABLE 16.-Contents, in percent, of platinum, rhodium, and palladium in the principal ore minerals of marginal deposits,

\begin{tabular}{|c|c|c|c|}
\hline & Platinum & Rhodium & Palladium \\
\hline $\begin{array}{l}\text { Pyrrhotite }_{\text {Chalcopyrite }} \\
\text { Pentlandite } \\
\text { Pente }\end{array}$ & $\begin{array}{l}50.44 \\
21.41 \\
28.15\end{array}$ & $\begin{array}{r}\text { 56. } 67 \\
\text { 6. } 30 \\
37.03\end{array}$ & $\begin{array}{l}65.20 \\
22.96 \\
11.84\end{array}$ \\
\hline
\end{tabular}

Pyrrhotite is clearly the principal carrier of the platinum metals, and chalcopyrite is the smallest, carrying little rhodium and less palladium. Pentlandite, according to these figures, contains comparable amounts of platinum and rhodium but less palladium. Analyzing similarly the figures of table 15 , and neglecting as before the content of platinum metals in pyrite, the data shown in table 17 are derived.

TABLE 17.-Contents, in percent, of platinum, rhodium, and palladium in the principal minerals of an offset deposit, Sudbury district

\begin{tabular}{|c|c|c|c|}
\hline & Platinum & Rhodium & Palladium \\
\hline $\begin{array}{l}\text { Pyrrhotite }_{\text {Chalcopyrite }} \\
\text { Pentlandite } \\
\text { Pente }\end{array}$ & $\begin{array}{l}\text { 44. } 20 \\
25.84 \\
19.96\end{array}$ & $\begin{array}{r}35.89 \\
.94 \\
63.17\end{array}$ & $\begin{array}{l}\text { 25. } 49 \\
34.19 \\
40.35\end{array}$ \\
\hline
\end{tabular}

These two sets of data indicate that the pyrrhotite of the offset deposit contains less platinum, less rhodium, and much less palladium than the pyrrhotite of the marginal deposits. The chalcopyrite of the offset deposit contains a little more platinum, very much less rhodium, and more palladium than the chalcopyrite of the marginal deposits. And the pentlandite of the offset deposit contains less platinum, much more rhodium, and much more palladium than the pentlandite of the marginal deposit. This analysis, however, refers to relative proportions of the platinum metals in the three ore-bearing minerals, and does not at all vitiate the conclusion that the total amount of the platinum metals in the offset deposits exceeds that of the marginal deposits.

Sperrylite, the diarsenide of platinum, is known to be present in most, if not all, of the nickel-copper ores, and it has been assumed to be the main source of platinum in the Sudbury district. But no quantitative data in favor of this interpretation have been presented, and in recent years this hypothesis has been questioned, notably by Lewis (1957, p. 1-5). In a letter (Oct. 18, 1960) to the writer, Mr. Lewis states: "In the examination of some hundreds of polished" 
sections of Sudbury ore minerals, I have rarely seen sperrylite. On the other hand, almost any sample of pyrrhotite, pentlandite, or chalcopyrite, when treated by fire assay, with a spectrographic analysis of the resulting bead, will show evidence of the presence of platinum metals." $\mathrm{He}$ therefore believes that sperrylite is not a major source of the platinum metals, but instead that they occur mainly as very dilute solid solutions in the major ore minerals, probably as substitutions in the crystal lattices.

The recent discoveries, however, of new platinum minerals by Hawley and Berry, Genkin and collaborators, Stumpfl, Borovskii, and others suggest strongly that numerous platinum minerals exist as discrete intergrowths in the sulfide ores. In general, therefore, the present state of knowledge indicates that in deposits of the Sudbury type, the platinum metals occur mainly in pyrrhotite, chalcopyrite, and pentlandite, both as minute included minerals but also as molecular replacements. The proportions of total and individual platinum metals derived from these two sources have not been determined.

\section{OTHER LODES}

Production was begun in 1962 at another platinum. bearing lode at Gordon Lake, 55 miles north of Kenora, in the Kenora mining division, southwestern Ontario. This is the property of the Nickel Mining and Smelting Corp., Ltd. About 3 million tons of ore have been proven to the 1,000 -foot level, but one shaft was sunk in 1962 to a depth of 1,817 feet, and other reserves will be established. The output is about 500 tons of ore daily. The nickel-copper concentrates are shipped first to Lac du Bonnet, Manitoba, and thence to Copper Cliff for smelting.

This ore deposit has been described by Thomson and others (1957). The ore which dips steeply north and lies in an east-west fault zone, is bounded on the north by gneiss and on the south by massive granite. Along the fault zone are irregular bodies of chromitebearing peridotite, which intrude the gneiss. These lenses of peridotite and the adjacent gneiss are mineralized by disseminated and massive pyrrhotite, pentlandite, and chalcopyrite. Joints in the peridotite and banding in the gneiss appear to control the placement of the ores. The tenors in nickel and copper are respectively 1.24 and 0.69 percent, and the gold and platinum metals add to 0.02 ounce per ton. The U.S. Bureau of Mines, however, reports the tenor in platinum metals to be about $\$ 3$ (Canadian) per ton of ore.

The Alexo mine is in east-central Ontario, about $31 / 2$ miles southeast of Kelso, and more than 100 miles northeast of the nearest point on the north range of the Sudbury basin. This property, when owned by the Mond Nickel Co., was operated from 1912 to 1920 , with a total production of about 51,860 tons of ore having a tenor of 4.2 percent nickel and 0.5 percent copper. The tenor in platinum metals was reported to be about 0.03 ounce per ton of ore. The property is now owned by the International Nickel Co. of Canada, Ltd., but has not been operated in recent years.

A cross section of the west drift of this mine, as given by Baker (1917), shows that the ore body where it was worked had a thickness of 10 to 12 feet and plunged steeply northwestward. It is bounded on the northwest side by serpentinite and on the southeast side by pillow lava. The ore body is known to have a length of 700 feet and to extend to a minimum depth of 350 feet below the surface. Sulfides are disseminated in the adjacent serpentinite, but the workable ore consists of massive sulfides, mainly pyrrhotite and pentlandite, with small amounts of chalcopyrite and pyrite.

Platinum metals have been recorded by O'Neill and Gunning (1934, p. 56-57 and 71-72) at five other sites in Ontario. These and six additional sites, taken from Thomson and others (1957), are listed below.

1. Shebandowan nickel-copper property, at Southwest Bay, lower Shebandowan Lake, Thunder Bay district, southwestern Ontario, about 73 miles west of Port Arthur. This property is now owned by the International Nickel Co. of Canada, Ltd.

2. Detroit-Algoma, mine, McTavish township, Thunder Bay district, southwestern Ontario.

3. Lode in Eby township, Timiskaming district, north of Sudbury.

4. Lode in Reaume township, Timiskaming district, north of Sudbury.

5. Cuniptau lode, in Strathy township, 4 miles northwest of Timagami and 60 miles northeast of Sudbury. Formerly owned by Ontario Nickel Corp., Ltd., now listed as property of Trebor Mines, Ltd.

6. Almo Lake, 4 miles west of Gordon Lake and 53 miles north of Kenora, Kenora Mining division, southwestern Ontario. Owner, Norpax Oils and Mines, Ltd.

7. Lode in Pardee township, about 50 miles southwest of Port Arthur, Port Arthur mining division, southwestern Ontario. Owner, Mattawin Gold Mines, Ltd.

8. Lode in Rathbun township, Sudbury mining division. Owner, Dolmac Mines, Ltd.

9. Milnet mine, Parkin township, Sudbury mining division. Property of Jonsmith Mines, Ltd. 
10. Nickel Offsets mine, Foy township, Sudbury district, property of Nickel Offsets, Ltd.

11. Quinn claim, Munro township, Ontario.

\section{MANITOBA}

A number of lodes, mainly of nickel-copper and copper-zinc ores, are known in Manitoba, and some of these have become significant producers of the base metals, though most of them contain no platinum metals. The most important of these lodes, which is platinum bearing, is in the Thompson district of north-central Manitoba, between two forks of the Nelson River and about 390 miles north of Winnipeg. The newly built town of Thompson, where the Thompson mine is located, is about 2 miles south of Burntwood River, a tributary of the North Fork of Nelson River, and is connected southeastward by a 30-mile spur to the Canadian National Railroad. The discovery and development of this mine are well described in a magazine supplement of the "Northern Miner," dated August 17, 1961. The geology and ore deposits were described briefly by Davis (1960) and more fully by Zurbrigg (1962).

Zurbrigg has outlined a rectangular area trending northeast, with a length of 85 miles and a width of 15 miles, which includes the more important nickel-copper ore deposits. These, named from northeast to southwest, are the properties at Moak Lake, Mystery Lake, Thompson, Pipe Lake, Hambone Lake, Grass River, and Soab Lake. The mineralization, however, extends northeastward to Ospwagan Lake and southwestward to Setting Lake, for a total distance of about 200 miles. The International Nickel Co., of Canada, Ltd., beginning in 1948, prospected this area thoroughly and made the first discovery at Moak Lake in 1952; the deposit at Thompson was found in 1956. Two shafts were sunk on the Thompson deposit, of which the principal working shaft reached initially a depth of 2,000 feet, with operating drifts on the 200-foot levels; but this shaft was sunk to a lower level in 1964. A third operating shaft was completed in 1966 to a depth of 2,400 feet. The mill that was built to handle these ores has a daily capacity of 6,000 tons of ore, but is operated at 4,500 tons a day, yields annually 75 million pounds of refined nickel. The nickel refining plant at Thompson is the second largest in the world. Three new mines being developed at Soab Lake, Birchtree, and Pipe Lake are scheduled to come into production in 1967. This mining is being done by the Canadian Nickel Co., Ltd., a subsidiary of the International Nickel Co. of Canada, Ltd. In 1962, the Thompson mine had 1,800 employees who live at Thompson, which has a population of 4,500 people. Electric power is drawn from the Kelsey hydroelectric generating station on Nelson River, about 53 miles from Thompson.

The ore reserves at the Thompson mine are estimated at 25 million tons, with a tenor of 2.8 percent nickel and 0.2 percent copper. The amount of palladium in these ores is comparable with that recovered at Sudbury, but the content of platinum and the minor platinum elements is lower. Besides the platinum metals, there are other byproducts of cobalt and sulfur. The deposit at Moak Lake probably contains ore reserves twice as great as those at the Thompson mine, but the content of nickel is only about 0.7 percent. The total reserves for the entire mineralized area are believed by Allen (1960) to be about 200 million tons and by the Northern Miner (1961) to be perhaps as much as 500 million tons.

The nickel ores of the Thompson-Mystery LakeMoak Lake area are stated by Wilson and Brisbin (1961) to be localized within an intensely deformed gneissic zone that lies between two great blocks of Precambrian rocks, of which the older lies to the southeast and the younger to the northwest, though both strike generally eastward. The older block consists dominantly of greenstone with less graywacke; the younger comprises limestone, quartzite, and conglomerate with a minor volume of lavas. The intermediate zone consists dominantly of gray and pink biotite gneiss which trends northeastward and is characterized by major thrust faulting along its length. This gneiss is believed to have been intruded as a granite into the sedimentary rocks and thereafter to have been greatly metamorphosed. Numerous other igneous rocks, mainly of intrusive character, occur within the gneissic zone; these include diorite, diabase, gabbro, and various peridotites, of which some are strongly serpentinized

The metasediments include quartzite, subgraywacke, limestone, skarn, an iron-formation, biotite schist, amphibolite, and minor amounts of greenstone. The peridotites are linearly arranged in zones parallel to the sheared metasediments and volcanics. The nickel deposits occur as massive ore bodies and stringers in schist, metasediments, and gneiss, and as disseminations and stringers in serpentinized peridotite.

The nickel-copper ores of this district exist in two distinct environments. At the outset of exploration, these deposits were thought by geologists to consist of disseminated ores in the included and bounding peridotites, as at Moak Lake. Later, however, deposits of higher grade were found in the metasediments of the mineralized zone of faulting, and these are represented by the ore deposit of the Thompson mine. This deposit may be described as a sheet of sulfide breccia, 
10 to 75 feet wide, which lies mainly in biotite schist and extends for a distance of $31 / 2$ miles. Only a very small part of the ore breccia lies in peridotite. The structure controlling the ore is an anticlinal fold, and the locus of the ore is a zone of schist which is continuous over the length of the anticline. The greatest concentration of ore is along the east limb of the south-plunging anticline, along its nose, and in minor crenulations.

The ore consists mainly of pyrrhotite, pentlandite, and pyrite, with less chalcopyrite and marcasite and traces of nickel arsenides. The sulfides occur as finegrained masses, lenses, and veinlets in brecciated schist and as stringers, veinlets, and disseminations in adjacent peridotite. Both the coarse and the fine-grained ores are termed "sulfide breccia," as many inclusions and remnants of country rock are included in the ore.

The other type of deposit is exemplified by the lowgrade ores at Moak Lake, Mystery Lake, Pipe Lake, Soab Lake, and at other localities within the mineralized zone. Such ores consist of disseminated pyrrhotite and pentlandite in intrusive bodies of serpentinite, and are reported to have tenors in nickel ranging from 0.45 to 0.75 percent. These deposits are characterized by low tenors in chalcopyrite and therefore in copper. All these deposits are in varying degrees platinum bearing.

A copper-nickel deposit, owned by the Sherritt-Gordon Mines, Ltd., is on Lynn Lake, about 145 miles northwest of Thompson. This property is reported to have reserves of $13,820,000$ tons of ore, and it was brought into production in 1953. The ore consists of pyrrhotite, pentlandite, chalcopyrite, and pyrite, which occur both in stockworks and in disseminated form. Small amounts of cobalt, zinc, gold, and platinum metals are also present. At the outset, the platinum metals were not recovered, because the chemical-leach method used in treating the concentrates was incapable of saving them. Improvements in milling practice, however, have resulted in a small output of platinum metals.

An area of some interest where platinum metals are present has been recorded by Wright (1932). This is in the Oiseau (Bird)-Maskwa Rivers area, in southeastern Manitoba, where several copper-nickel replacement deposits occur in Precambrian rocks. The principal country rock comprises steeply folded andesitic lavas and quartzose tuffs which are intruded by dikes and stocks of peridotite and gabbro, as well as granitic rocks. The ores are copper-nickel replacement deposits which are localized in sheared zones in volcanic rocks close to and in part within marginal parts of the basic and ultrabasic rocks. The principal ore minerals are pentlandite, nickeliferous pyrrhotite, chalcopyrite, and cubanite. At the Hititrite mine, in the Maskwa River area, the tenor of platinum metals was found to be 0.02 percent.

Another area recorded by Uglow (1919) is near The Pas, in western Manitoba, about 75 miles south-southeast of Flin Flon. Here, in the shaft of the Northern Manitoba and Development Co., platinum was found in a gold-quartz vein, with a tenor alleged to have been $\$ 17$ a ton. Another locality mentioned by O'Neill and Gunning (1934) is in the Star Lake district, in southeastern Manitoba. The deposit near The Pas is another occurrence of platinum in a quartz vein, in which gold occurs in pyrite and arsenopyrite; the tenor of platinum was determined to be 0.10 ounce per ton of ore.

\section{QUEBEC}

A nickel-copper ore deposit has recently been discovered in a Motte township, adjacent to Malartic, in southwestern Quebec. Operated by the Marbridge Mines, Ltd., this property is owned jointly by Falconbridge Nickel Mines, Ltd., and the Marchant Mining Co. Drilling has been done to a depth of 1,200 feet, and ore has been developed from a shaft at the 750-, $900-$, and 1,050-foot levels. Production was begun in 1962, with a daily output of 400 tons of ore, from which 2,500 tons of concentrates is produced monthly. These are smelted at Falconbridge. The tenor in nickel is 2.11 percent. The ore is platinum bearing, but the tenor in platinum metals has not been announced.

Another ore deposit containing nickel and copper has been found in the Belleterre district, Guillet township, of southwestern Quebec. This property is being developed by the Lorraine Mining Co., but 80 percent of the stock is owned by the McIntyre-Porcupine Mines, Ltd. Drilling indicates ore reserves of 550,000 tons, and mining was planned to begin in 1965. The tenor in nickel is about 2.1 percent, and the tenor in platinum metals is reported to be about 0.05 ounce per ton of ore.

Traces of platinum metals have also been reported by O'Neill and Gunning (1934, p. 55) in chromite ore from St. Cyr, Quebec.

\section{NORTHWEST TERRITORIES}

A platinum-bearing nickel-copper lode, originally called the Rankin Inlet deposit was discovered in 1928 at the top of a small peninsula, about 7 miles west of Falstaff Island. The literature has numerous references to this deposit, but the ones which form the basis of this description are principally those by Weeks (1932), 
Drybrough (1932), O'Neill and Gunning (1934), the Imperial Institute (1936), Pelzer (1950), the U.S. Bureau of Mines Mineral Trade Notes (1961), and miscellaneous notes in Canadian and United States mining journals.

The Rankin Inlet lode was prospected intermittently for nearly 30 years before production began in 1957 . The property produced 460,000 tons of ore up to the time when operations ceased in 1962. The mean tenors of nickel and copper, according to the U.S. Bureau of Mines Mineral Trade Notes (1961, v. 53, p. 41), were 3.47 and 0.99 percents; and from other sources the tenors of platinum and palladium are known to have been respectively 0.03 ounce platinum and 0.06 ounce palladium per ton of ore. The platinum metals were not recovered.

The local geologic features comprise a lenticular sill of serpentinized pyroxenite, from 200 to 300 feet thick, which lies between a sequence of overlying "upper volcanics" and an underlying sequence of Precambrian sedimentary rocks. The ore is localized in the basal part of the pyroxenite and is interpreted as magmatic ore that resulted from a splitting of the magma into rock-forming and ore-mineral fractions before its cooling and crystallization. The ore minerals that have been identified, named in the order of their abundance, are pyrrhotite, pentlandite, chalcopyrite, magnetite, pyritê, violarite, marcasite, and gersdorffite. The platinum metals are included mainly in pentlandite and pyrrhotite and in smaller amounts in chalcopyrite.

Another lode of a similar type has been found at Ferguson Lake, about 150 miles west of Rankin Inlet. Much drilling has been done at this property, but the results of this work are not known to the writer.

A lode in which the platinum metals occur in a vein of quartz and pyrite was found by Wait (1910) in a sample collected from the northern part of Baffin Island on Strathcona Sound, an arm of Admiralty Island.

A large layered basic pluton has recently been discovered in the Copper-mine area, in the northern part of Northwest Territories, and has been described by Smith and Kapp (1962). This mass, known as the Muskox intrusion, is dikelike in plan and funnelshaped in cross section. It has four principal units which include a feeder, marginal zones, a central-layered series, and an upper border group. The overall length is 74 miles, of which 37 miles represents the feeder, which contains bronzite gabbro and picrite in zones parallel to a nearly vertical axis. The thickness of the feeder ranges from 500 to 1,800 feet. The marginal zones are parellel to the walls of the intrusion, which dip inward at an angle of $23^{\circ}$ to $57^{\circ}$; these zones grade from bronzite gabbro at the contact through picrite and feldspathic peridotite to peridotite and in places dunite. The marginal zones range in thickness from 200 to 1,200 feet. The central zone is 8,500 feet thick and is known to consist of 38 principal layers of dunite, peridotite, pyroxenite, and gabbro. These layers are nearly horizontal and are discordant to the marginal zones. The upper zone, which is 200 feet thick, shows an upward gradation from gabbro to granophyre.

Nickel-copper ores occur along the walls of the intrusion, and within one horizon of pyroxenite are ores containing disseminated chromite, copper-nickel sulfides, and platinum metals. A marked resemblance exists between this ore body and the Merensky zone of the Transvaal, and its great size suggest that another important copper-nickel-platinum deposit of the Sudbury type may have been discovered.

\section{BRITISH COLUIMBIA} LODES

A platinum-bearing nickel-copper lode, owned by the Pacific Nickel Mines, is about 75 miles east of Vancouver and 7 miles northeast of Hope. The principal habitat of the ore is stated by Aho (1956), to be a stocklike body of pyroxenite that has a visible diameter of about $1 \frac{1}{2}$ miles and that has cores of peridotite and hornblendite. This mass appears to cut an adjacent diorite, but is itself cut by dioritic dikes-a fact suggesting approximate contemporaneity. The ore bodies are elongate, steeply pitching, parsnip-shaped structures consisting in part of sulfides with olivine-rich ores and in part of massive sulfide-silicate bodies. The principal ore minerals are disseminated and massive pyrrhotite with subordinate amounts of pentlandite and chalcopyrite. The ore has an average tenor of 1.4 percent nickel, 0.5 percent copper, and 0.01 ounce platinum metals per ton. The sulfides are considered to be of hydrothermal origin.

A score of platinum-bearing lodes in British Columbia are mentioned by O'Neill and Gunning (1934), but none of these have been mined, or appear to have much chance of being developed. The more important ones, which include several occurrences of the platinum metals in siliceous gangue minerals, are summarized briefly below. Both Uglow (1919) and Vogt (1927) have listed the principal lodes in which platinum occurs in this environment. The list by O'Neill and Gunning follows:

1. Swede group of claims outside Lockeport Harbour, east side of Moresby Island, about 120 miles southsouthwest of Prince Rupert. The lode is an immense deposit of low-grade copper ore, consisting 
of small veinlets and disseminations of chalcopyrite and bornite in diabase. A sample of the bornite assayed 0.01 ounce platinum and a trace of palladium to the ton.

2. Scottie Creek, about 140 miles north-northeast of Vancouver. The lode is a deposit consisting of disseminations, nodules, and lenses of chromite in serpentinite derived from an ultrabasic intrusive. Two assays of the chromite showed 0.02 and 0.10 ounce of platinum to the ton.

3. Mount Ida, about 50 miles east of Kamloops. The platinum occurs in quartz veins and in quartz stringers that lie in a wide shear zone and that contain copper, lead, and zinc sulfides. Assay show values ranging from 0.02 to 0.03 ounce platinum metals to the ton.

4. The Tulameen placer district, described on pages 29-31. The platinum-bearing streams head in areas of peridotite and pyroxenite. According to O'Neill and Gunning, platinum has been reported to occur in serpentinite dikes, masses of chromite, in replacement and vein deposits, in sulfides in greenstone, and in sheared and altered granodiorite. Assays ranged from 0.1 to 4.0 ounces per ton of ore.

5. Mother Lode claim, Burnt Basin, about 3 miles west of Coryell. The country rock consists of basic eruptive rocks, largely altered to serpentinite as in the Tulameen placer area. Platinum occurs with chalcopyrite, pyrite, galena, sphalerite, and molybdenite in gold-bearing quartz veins between two porphyry dikes. Assays show tenors in platinum metals ranging from 0.06 to 0.10 ounce per ton.

6. Nickel Plate mine, at Hedley. Platinum is reported to occur with auriferous arsenopyrite in metamorphosed limestone. One assay indicates a tenor of 0.5 percent platinum, which was thought to be present as sperrylite.

7. The old Sappho property, close to the international boundary between British Columbia and Washington and about $2 \frac{1}{2}$ miles east of Midway. The country rock is argillite intruded by diorite, pyroxenite, and alkali-syenite dikes. Chalcopyrite close to the pyroxenite assayed 0.03 ounce platinum to the ton of ore.

8. Maple Leaf and several other properties in the Franklin Mining camp, about 135 miles east-northeast of Hope. A contact metamorphic deposit, called "The black lead," occurs in impure quartzite and greenstone, near the contact with a shonkinite, which is a marginal phase of an augitesyenite intrusive. The principal ore minerals are chalcopyrite, pyrite, a little bornite, and the acces- sory minerals apatite and sphene. Numerous assays show tenors in the platinum minerals ranging from 0.007 to 0.26 ounce per ton of ore.

9. Properties in the vicinity of Cascade, near the international boundary line, a few miles south of the Mother Lode claim. One of these is a chromite, deposit in serpentinized dunite, which contains platinum metals from traces up to 0.15 ounce per ton of ore.

10. Sullivan mine, about 60 miles east-northeast of Nelson. Palladium and a little platinum are recovered commercially from the lead-zinc ores of this property.

11. Cable claim and vicinity of Nome claim, in Ainsworth mining division. The ore at the Cable claim is auriferous pyrite in a quartz vein, with a tenor in platinum of 0.07 ounce per ton. The ore near the Nome claim came from a slide on Kaslo River, and the platiniferous rock, which resembles feldspathic quartzite, is reported to have assayed 0.05 to 0.08 ounce platinum to the ton of ore.

\section{PLACERS}

The placers of British Columbia lie in the many tributary valleys of the Columbia, Frazer, Peace, and Liard Rivers, but the belt continues northwestward into Yukon, and veers thence westward into interior Alaska.

Some of these Canadian gold placers also contained small amounts of the platinum metals which generally yielded no significant production. One area, however, known as the Tulameen district, had in earlier years an important output of the platinum metals; and because the geology of this area has genetic significance, it is briefly described in succeeding pages.

\section{TULAMEEN DISTRICT}

The Tulameen district, as mapped geologically by Camsell (1913) on a scale of $1: 62,500$, is an area of 13 miles square, with the southern boundary 31 miles north of the international boundary between Canada and the United States and the western boundary approximately at long $120^{\circ} 58^{\prime} \mathrm{W}$. A geologic map of a larger area, called the Princeton map area, was later prepared on a smaller scale by Rice (1947). The geography and geology of a part of the Tulameen district and some adjacent territory, taken from the maps by Camsell and Rice, are shown in figure 2. The platinum deposits of the Tulameen district are also described by O'Neill and Gunning (1934, p. 89-98).

The sedimentary country rock of this area consists. principally of the Tulameen group of rocks, which are mainly andesitic flows and breccias, limestone, and 


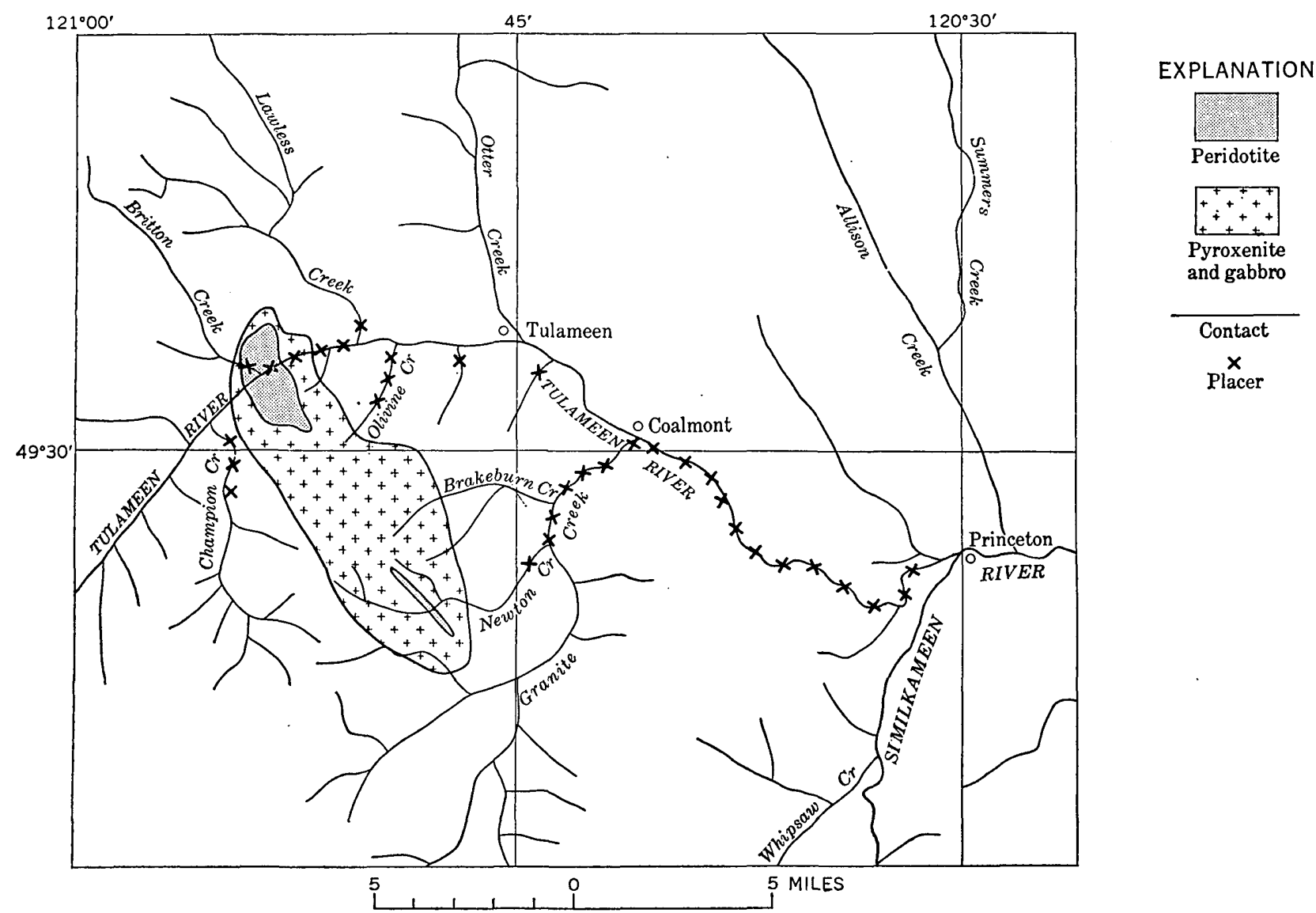

Frgure 2.-Gold-platinum placer deposits, Tulameen Valley, British Columbia. (Generalized from Camsell, 1913, and Rice, 1947.)

argillite, of Triassic or Carboniferous age. There are five igneous formations, all of which are believed to be of Jurassic age; those which bear particularly on the origin of the platinum metals are two formations of ultrabasic rocks, which are shown in figure 2. Also present are Oligocene sedimentary and volcanic rocks, capped by olivine basalt. Intense glaciation of this area during the Pleistocene epoch produced U-shaped principal valleys and hanging tributary valleys. Most of the placers are therefore of postglacial age, though some that lie in protected valleys athwart the main movement of the ice may antedate Wisconsin time.

A large intrusive mass of pyroxenite and gabbro, with a length of 11 miles and a maximum width of $31 / 2$ miles is transected near its northwestern end by the Tulameen River and extends southeastward into the drainage of Granite Creek. A small body of peridotite occurs near the northwestern end of the pyroxenite and gabbro, and a dikelike body of peridotite is included near its southeastern limit. Some ultrabasic rocks are also reported in the upper valley of Lawless Creek.
All the streams that carry platinum metals in workable quantities head in ultrabasic rocks, or in areas closely adjacent thereto; and the peridotite is considered to be more important as a source rock than the pyroxenite and gabbro. The streams that have yielded platinum metals are Tulameen River and Granite Creek with its three northern tributaries called Brakeburn, Newton, and Badger Creeks; Olivine (Slate) Creek, Cedar and Hines Creeks, respectively east and west of Olivine Creek, and Champion Creek; and Lawless (Bear) and Britton (Eagle) Creeks, which are northern tributaries of Tulameen River. Gold and platinum have also been found along Similkameen River, from 30 miles above to 20 miles below Princeton, where they were doubtless transported in glacial deposits. The deposits downstream from Princeton were worked intermittently, but not very successfully.

The Tulameen River was generally productive from Princeton upstream to Coalmont, at the mouth of Granite Creek, a distance by stream of about 12 miles, though the deposits were not of very high grade. From Coalmont upstream to Olivine Creek, the deep glacial 
gravels of Tulameen River have not been worked; but the stream and terrace gravels from Olivine Creek upstream to Champion Creek were found to constitute high-grade placers. The coarsest platinum on Tulameen River was also found within this stretch. The deep deposits downstream from Olivine Creek mav sometime be dredged successfully.

The placers of Granite Creek, from the Tulameen River upstream to the mouth of Newton Creek, had the highest tenor in platinum metals of the district. Upstream from Newton Creek, the productive gravels are deeply buried under glacial deposits, and have not been successfully mined. Olivine Creek, for a distance of 4 miles from its mouth, also had high-grade gravel deposits.

Gold is almost everywhere more plentiful in these placers than the platinum metals. The gold-platinum ratio was found to be variable, depending on the locations of the placers, ranging from $4: 1$ in the lower Tulameen valley to $1: 1$ in the valley of Olivine Creek. A mean value of this ratio can be obtained from the gold production (in dollars) and the platinum production in ounces for the years 1887-1899, 1901-1902, and 1904-1905, as given by O'Neill and Gunning (1934, p. $95)$. Regarding the dollars of the table for these years as representative of the value of pure gold (not gold bullion), and taking the fineness of the placer gold as 935, the mean gold:platinum ratio for the district appears to be about $2: 1$.

The platinum metals occur as small, rounded, equidimensional grains, many of which are pitted as a result of the weathering out of other minerals; and some have adhering grains of chromite or magnetite. These grains, in the upper valley of Tulameen River and its tributaries, ranged in size from less than one millimeter to 4 millimeters, and the largest recorded nugget weighed half an ounce. A sample, recently obtained by the writer, came from a right limit terrace, about $1 \frac{1}{2}$ miles west of Princeton. This was found to have the following magnetic properties:

Ferromagnetic 32.9 percent Paramagnetic . . . Very weakly magnetic 2.9 percent

The heavy minerals recovered from the gold-platinum placers included magnetite, chromite, a little pyrite, and rarely native copper. The gold, judging from one assay given by O'Neill and Gunning $(1934$, p. 98) was of high grade, with a fineness of about 935 .

The principal source of most of the platinum metals found in this area is the peridotite, though the chemi- cal analyses recorded by Kemp (1902, p. 47-51) also indicate their presence in serpentinite, pyroxenite, and chromite. The platinum metals have also been reported in this district in other environments, at one place with pyrrhotite, chalcopyrite, pyrite, and sphalerite as a replacement deposit in limestone, at a second locality with copper sulfides in a greenstone dike, and at a third site in a shear zone in granodiorite.

No superior analyses of the platinum metals from the Tulameen district are available, but one inferior analysis was made by Hoffman (1888), and another is inferred from a record of production in 1930. The analysis by Hoffman is shown both with and without base metals, as $\mathbf{A}_{1}$ and $\mathbf{A}_{2}$. The production record is given as analysis B. These analyses are shown as table 18.

$\mathrm{T}_{\mathrm{ABLE}}$ 18.-Composition, in percent, of platinum metals, Tulameen district

\begin{tabular}{|c|c|c|c|c|}
\hline & $A_{1}$ & $A_{2}$ & B & Mean \\
\hline Platinum_ & 73. 20 & 83. 33 & 86. 09 & 84. 71 \\
\hline Iridium_...... & 1. 16 & 1. 32 & 2. 78 & 2. 05 \\
\hline Osmium plus iridium. & 10.68 & 12. 16 & 10. 14 & 11. 15 \\
\hline Rhodium & 2. 61 & 2. 97 & .60 & 1. 79 \\
\hline Palladium_....... & .19 & .22 & .39 & .30 \\
\hline Copper & 3. 44 & $\ldots \ldots$ & ..... & $\ldots \ldots$ \\
\hline Iron & 8. 72 & & & \\
\hline Total & ח00 100 & 100.00 & 100.00 & 100.0 \\
\hline
\end{tabular}

These two analyses are in general agreement in their tenors of platinum, and in the combined tenors of osmium plus iridium. Referring to table 37 of this report, it will be seen that the mean value of platinum in table 18 is quite similar to that recovered in the Goodnews Bay district, Alaska, and if the mean value of iridium is added to that of osmium and iridium, it appears that the sum of these two metals is also comparable with that of the Alaskan product.

The total output of platinum metals from the Tulameen district is not accurately known. According to Camsell $(1913$, p. 143), the production for 17 years in the period 1885-1909 was 9,860 fine ounces, but the output has not been recorded for the period 1910-32, after which mining practically ended. According to Quiring (1962, p. 93), the production of placer platinum from Canada for the period 1876-1930 amounted to about 18,775 troy ounces, most of which came from the Tulameen placers. There was a maximum production of 2,120 ounces in 1891. Poitevin in (1924) and O'Neill and Gunning (1934) agree that if proper records had been kept, the total production from the beginning to the end of mining should be approximately 20,000 ounces. 


\section{OtHer PLACERS}

Numerous other gold placers in British Columbia are known to contain small amounts of platinum metals, but none of these has yielded any significant production. O'Neill and Gunning (1934, p. 76-89 and 98102) have described these deposits and have published sketch maps showing their locations in British Columbia. They also have given what is known of the gold and platinum tenors of the gravels. It suffices here merely to tabulate the known localities, as follows.

Localities of platinum-bearing placers in British Columbia

1. Thibert Creek, a tributary of Dease River, Liard mining division.

2. Ruby Creek, Atlin mining division.

3. Graham Island, Queen Charlotte mining division.

4. Finlay River and tributaries, Omineca mining division.

5. Parsnip River and tributaries, Omineca mining division.

6. Dog Creek, a tributary of Stuart River, Omineca mining division.

7. Peace River, Peace River mining division.

8. Fraser River and tributaries, Quesnel mining division.

9. Government Creek, an eastern tributary of Fraser River, Cariboo mining division.

10. Quesnel River and tributaries, Quesnel mining division.

11. Bonaparte River and tributaries, Clinton mining division.

12. Tranquille River and tributaries, Kamloops mining division.

13. North Thompson River and tributaries, Kamloops mining division.

14. Deadman River and tributaries, Ashcroft mining division.

15. Coquihalla River and tributaries, Yale mining division.

16. Similkameen River and tributaries, Similkameen mining division. The Tulameen district lies in the drainage basin of Similkameen River.

17. Kettle River and tributaries, Greenwood mining division.

18. Okanagan River and tributaries, Osoyoos mining division.

19. Lardeau River and tributaries, Lardeau mining division.

20. Tributaries of Columbia River, Revelstoke mining division.
21. Tributary of Jervis Inlet, Vancouver mining division.

22. West Coast of Vancouver Island, Vancouver mining division.

The following localities in Yukon are also mentioned by O'Neill and Gunning (1934, p. 108-111) :

1. Teslin (Hootalinqua) River and tributaries.

2. Kaskawulsh River and tributaries.

3. Kluane River and tributaries, Kluane mining division.

Alluvial platinum is also recorded from the bars of the North Saskatchewan River, Alberta.

\section{YURON}

The principal nickel-copper deposit of Yukon (Yukon Territory) is the Wellgreen lode, which was discovered in 1952 and which is owned by the HudsonYukon Mining and Smelting Co. This property is in the Kluane Lake district, about 150 miles west of Whitehorse, Yukon Territory. Reserves of ore are reported to range from 500,000 to 737,000 tons, with tenors in nickel of 2.04 to 2.14 percent and of copper from 0.74 to 1.42 percent. Platinum and palladium are reported to range respectively from 0.038 to 0.049 ounce and 0.27 to 0.32 ounce per ton of ore. A pilot shipment of 300 tons, on which these tenors are presumably based, was tested at Flin Flon in 1955.

Another property in Yukon is that of the Canalask Nickel Mines, Ltd., in the Kluane Lake district. The ore reserves amount to 550,000 tons, with an average tenor of 1.68 percent nickel and 0.04 percent copper. The content of platinum metals has not been published.

\section{OTHER PROVINCES}

Other occurrences of the platinum metals are recorded by O'Neill and Gunning (1934, p. 54, 55, 75, 135) in the provinces of Nova Scotia, Saskatchewan, and Newfoundland. Two properites are mentioned in the eastern part of Halifax County, Nova Scotia, where small amounts of platinum occur in a scheelite-quartz vein.

Platinum metals were found in two drill holes near the Rottenstone Lake, about 80 miles north of Lac la Ronge, northern Saskatchewan. The country rock at these sites is gneiss and schist, and the nickel-copper ores that contain platinum and palladium appear to occur in oxidized zones within these rocks.

Small amounts of platinum are reported by Howley $(1907$, p. 783) to have been found in chromite in a serpentinized area in the vicinity of Mount Cormack, central Newfoundland. 


\section{REPUBLIC OF SOUTH AFRICA}

The platinum metals are widely distributed in the Republic of South Africa, where they occur in the provinces of the Transvaal and Cape of Good Hope, in association with nickel-copper ores. In the same environment they extend northward into Rhodesia, and they are also recovered as a byproduct of the copper deposits in Katanga, Republic of the Congo, and in Zambia (formerly Northern Rhodesia). The platinumbearing lodes occur in various environments, and the platinum metals, though mainly in the form of platinum mineral compounds, occur at some places as native platinum alloys. The most important of the platinum lodes are related genetically to the noritic and pyroxenitic formations of the Bushveld igneous complex (or series), of central Transvaal; and the principal productive areas are in the Rustenburg and Pilandsberg districts, at the southwestern and western sides of this complex.

The gold fields of the Witwatersrand are in southcentral Transvaal, contiguous to Johannesburg, and they extend southward into the Orange Free State. These are ancient lithified placers mined as lodes, from some of which are produced significant amounts of native platinum metals as a byproduct of gold mining. This output, though relatively small, represents the world's largest production of osmiridium.

The first definitely recorded discovery of platinum in the central Transvaal was made in 1923 by Adolph Erasmus, a prospector, who panned it from a termite mound at a site about 8 miles west-northwest of Naboonspruit. The first discovery of platinum within the norite belt was made less than a year later by A. F. Lombaard, who panned it from the gravels of a dry watercourse in the western part of the Lydenburg district. The lodes of the Waterberg, Potgietersrust, and Rustenburg districts were discovered, respectively, in 1924, 1925, and 1926.

The mining of platinum was begun first in the alluvial and eluvial deposits, of which the most promising were in the Lydenburg district, though such deposits were also found at other localities. This mining proved to be unprofitable, because most of the platinum occurred in bedrock as very fine particles locked in sulfides, so that even if freed by weathering they were subject to downstream movement and dispersal. Mining of the lodes soon began in the Lydenburg, Pretoria, Rustenburg, Pilandsberg, Waterberg, and Potgietersrust districts. Wagner (1929) lists at various places in his book a dozen or more companies who undertook such mining, but practically all this work, except in the Rustenburg and Pilandsberg districts, was finally discontinued, either because it was unprofitable or because it was so much less profitable than the present mining at the west side of the Bushveld complex. The more promising of these deposits were eventually ac-. quired by the Rustenburg Platinum Mines, Ltd., which now controls all lode mining in the Rustenburg and Pilandsberg districts. This company, in turn, is a subsidiary of a holding company known as the Johannesburg Consolidated Investment Corp., Ltd.

Practically all the platinum metals now being recovered from the lodes of the Transvaal come from a specific zone within the norite belt, called the Merensky zone, described on pages 39-42. This is a very regular igneous sheet that has been traced for 250 miles in the Rustenburg, Pilandsberg, Lydenburg, and Potgietersrust districts. The platinum ores of the Merensky zone and other lodes of the Transvaal represent the greatest known reserves of platinum metals in the world.

The production of platinum metals in the Republic of South Africa (other than osmiridium) has come largely from the nickel-copper lodes of the 'Transvaal, though a small but indeterminate part has come from placers and other sources. According to the data published by Quiring (1962, p. 96) and from other sources, the total production of the Republic of South Africa from 1925 to 1962 , inclusive, has been 4,966,000 ounces, with a maximum output in 1957 of 603,700 ounces.

The production of platinum metals from the Transvaal has been limited in recent years by the demands of the world's metal markets. Since 1964, however, a program of expanded production has been in progress by the Rustenburg Platinum Mines, Ltd., and this has been corroborated by statements made by this company in the Platinum Metals Review, (v. 10, no. 2, p. 52-53, 1966, v. 11, no. 1, p. 9, p. 131, 1967; and v. 12 ; no. 4, p. 139). Permanent mining facilities are now being installed that will lead to a production of 1 million ounces by 1969 . The ore reserves at Rustenburg alone are considered sufficient to maintain this output well beyond the year 2,000 .

\section{TRANSVAAL AND ORANGE FREE STATE PROVINCES GENERAL GEOIOGY}

The general geology of the Bushveld igneous complex and of the surrounding rocks is similar in some respects to that of the Sudbury district, but markedly different in others. Both these areas are characterized by a synclinal basin floored by basic igneous rocks, and both areas are surrounded by Precambrian rocks; but most of the other characteristic features are dissimilar, though a tendency has existed to correlate 
the geologic and petrographic features of the Bushveld and Sudbury areas.

The general stratigraphy adopted in this paper is that proposed by Hall (1932), who worked for more than 30 years in the Transvaal, though it is evident from a late geologic map of the Transvaal, compiled in 1955 by E. C. Truter and P. J. Rossouw, that new interpretations have been made. A recent memoir of the Geological Survey of South Africa, by Coetzee (1960, 198 p.), gives the systems, series, and smaller stratigraphic divisions now accepted by the Geological Survey of South Africa, with special reference to the Orange Free State.

The oldest rocks of this region are the metamorphic rocks of the Swaziland system or Basal Complex. Unconformably above these are the sedimentary rocks of the Witwatersrand system; unconformably above these lie andesitic lavas, porphyries, and pyroclastics, together with the sedimentary rocks of the Ventersdorp system, and unconformably above these are the sedimentary and andesitic rocks of the Transvaal system, of which the Pretoria series is the uppermost division. The Basal Complex and the Witwatersrand, Ventersdorp, and Transvaal systems are of Precambrian age. The Transvaal system comprises rocks with a maximum thickness of 25,000 feet. The Pretoria series, which constitutes the upper part of the Transvaal system, consists of sedimentary rocks, lava flows, and sills with a total thickness of about 13,000 feet; and within the Pretoria series lie the basic and ultrabasic intrusives and extrusives that compose the Bushveld igneous complex.

The principal rocks of the Pretoria series are quartzite, shale, and conglomerate, of which the uppermost formation below the norite lopolith is the Magaliesberg quartzite, which at many places constitutes the floor of the norite. One feature of the Pretoria series, according to Hall's classification, is the presence of three formations of basic amygdaloidal lavas, separated from one another by sedimentary rocks. Between the two younger of these lava sheets occur sills of the same petrographic character as those which intrude the Magaliesberg quartzite and underlying shales. These lavas and sills, together with the sedimentary rocks that separate them, are commonly included as a part of the Bushveld igneous complex, as they are regarded by some geologists as the earliest manifestations of the igneous activity that later produced the main noritic and associated rocks of the Bushveld complex.

\section{BUSHVELD COMPLEX}

The basal horizons of the Bushveld igneous complex have already been defined. Above the Magalies- berg quartzite, and commonly in contact with it, occurs a great intrusive mass of norite and associated ultrabasic rocks, which constitutes the part of the Bushveld igneous complex that is the principal source of the platinum-bearing nickel-copper ores. Where the noritic and associated rocks are not in contact with the Magaliesberg quartzite, they are floored by the Dullstrom volcanic formation, which overlies the quartzite at some localities, and is the youngest of the three volcanic formations cited above.

The Bushveld complex also includes three younger formations. Above the noritic rocks, but at some places intruding them, is a formation generally called the Red Granite. This does not usually rest directly upon the noritic rock, as it is more commonly separated by a band of felsite, granophyre, or quartzite. It has the general configuration of a sill, however, with a thickness measurable in hundreds, rather than thousands of yards, and is generally regarded as younger than the noritic rocks. Above the Red Granite is a sheet of granophyre, with a thickness of about 1,200 feet, which is probably younger than the Red Granite. The uppermost igneous formation of the Bushveld complex is a mass of felsite and derived pyroclastics, which are older than the norite lopolith. These felsites and related rocks, with a thickness of about 8,500 feet, are interpreted as the surficial equivalents of the underlying granophyre. They also are regarded as the basal part of the Rooiberg group, which commonly forms the roof of the Bushveld igneous complex, and is considered to represent the uppermost part of the Pretoria series. The ages of the intrusive and extrusive rocks of the Bushveld complex, including the sedimentary rocks of the Rooiberg group, are considered by South African geologists to be of late Precambrian age.

The Rooiberg group is overlain successively by the Waterberg and Karroo systems, though the geologic map by F. C. Truter and P. J. Rossouw (South Africa Geological Survey 1955), shows that these two systems have been replaced by five other systems which, named in order of decreasing age, are the Loskop, Waterberg, Nama, Kaap, and Karroo systems. The Loskop and Waterberg systems are now considered to be of Precambrian age; the Nama and Kaap are called Devonian to middle Carboniferous; and the Karroo system is regarded as Triassic to early Jurassic. None of these systems figures prominently in the geology of the Bushveld igneous complex, except that they overlap and therefore conceal parts of the norite lopolith and its included Merensky zone. Still later geologic maps by the Geological Survey of South Africa (1960 and 
1967) show further modifications of the stratigraphic sequence.

The formation of noritic and associated rocks lies in an ovaloid synclinal basin which trends east-northeast, with major and minor axes respectively of about 280 and 110 miles. The surficial extent of these rocks, as shown in figure 3 including the eastern and northeastern area with the western and northwestern area, is about 20,000 square miles. This intrusive is regularly layered and dips inward toward its center at angles ranging from $5^{\circ}$ to $50^{\circ}$. The maximum thickness of these basic and ultrabasic rocks varies from one locality to another, ranging from 5,000 to 18,200 feet, with a mean thickness taken from the data presented by Hall (1932, p. 268) of about 11,800 feet. This intrusive therefore has the general form of a gigantic sill.

A thick central part of the noritic intrusive is generally believed to plunge to a great but undetermined depth and under this interpretation warrants the designation of a lopolith. There is, however, a zone northnorthwest of Potgietersrust where only the upper part of the intrusive is present, as the lower zones were not developed in the form of a sill penetrating the country rock. Instead, this protuberance, which extends about 65 miles north-northwesterward from the projected rim of the lopolith, may best be regarded as a great dike that penetrated deeply into the country rock. West of Pilandsberg, only the lower part of the lopolith is present, and this is believed to have resulted from the erosion of the upper horizons. This lower zone includes inliers of quartzite and metamorphosed shale that indicate the irregular nature of the basal contact. The northern contact of the noritic formation with the rocks that underlie it is not exposed for about 130 miles, as it is overlapped in this stretch by younger sedimentary rocks. Owing to the same cause, a similar hiatus of about 90 miles exists along the southern contact. For these reasons, the minor axis of the lopolith, as given above, is materially different from that stated by Wagner and Hall, which applies to the noritic lopolith as a whole, and includes the intrusive branch that extends north-northwest from Potgietersrust.

The norite and related rocks are divided by Wagner $(1929$, p. 44) into three principal zones, which named from bottom to top are the differentiated or critical zone, the main belt, and the upper zone. Wagner thus includes in his differentiated zone the chill zone, transition zone, and critical belt proposed by Hall (1926).

A generalized section of the norite lopolith south and southwest of Pilandsberg has been presented by Wagner (1929, p. 45) as follows:

\footnotetext{
$329-505-69-4$
}

Composite section across norite lopolith near Pilandsberg

Upper zone_._.
Norite, grading upward into
gabbro and syenite.
$\begin{aligned} & \text { Diallage norite with stratiform } \\ & \text { segregations of titaniferous } \\ & \text { magnetite and labradorite- } \\ & \text { anorthosite. } \\ & \text { Diallage norite. }\end{aligned}$
Approximate thickness
(feet)

Differentiated or critical zone.

Bronzitite with bands of anorthosite and pseudo-porphyritic diallage norite (contains Merensky zone).

Bronzitite with seams and lenses of chromitite.

Bronzitite with isolated lenses of harzburgite, differentiated diallage norite, and chromitite.

Bronzitite with lenses of harzburgite and anorthositic norite containing bands of bytonite-anorthite and labradorite anorthosite (contains Vlakfontein nickel zone)

Bronzitite with lenses of harzburgite.

Pyroxenitic olivine-norite probably grading downward into the basal or chill zone of diabasic quartz-norite.

Minimum thickness in this area.........

15,100

\section{ORE DEPOSITS}

Ore deposits that contain the platinum metals include numerous types with local variations, and the scattered over a great area along the periphery of the intrusive complex. The best understanding of these ores can be obtained by describing the petrography and mineralogy of type deposits, with emphasis upon the mode of occurrence of the platinum metals. This approach is much facilitated by a generalized genetic classification of the different ore deposits of the norite zone of the Bushveld complex. Emphasis is placed upon the productive ores of the Merensky zone, whereas the other types of deposits are only briefly described.

A general classification of the platinum deposits related to the basic and ultrabasic rocks is as follows:

$$
\begin{gathered}
\text { Classification of platinum deposits of the noritic and } \\
\text { related rocks }
\end{gathered}
$$

\section{A. Magmatic segregates:}

1. Ores in which the platinum metals, mainly platinum and palladium, are associated with nickel-copper sulfides in norite and pyroxenite.

2. Ores of chromitite, containing native platinum metals.

3. Ores of dunite, containing native platinum metals.

B. Pneumatolytic, hydrothermal, and contact metamorphic deposits in sedimentary rocks subjacent to the basic and ultrabasic intrusives. 


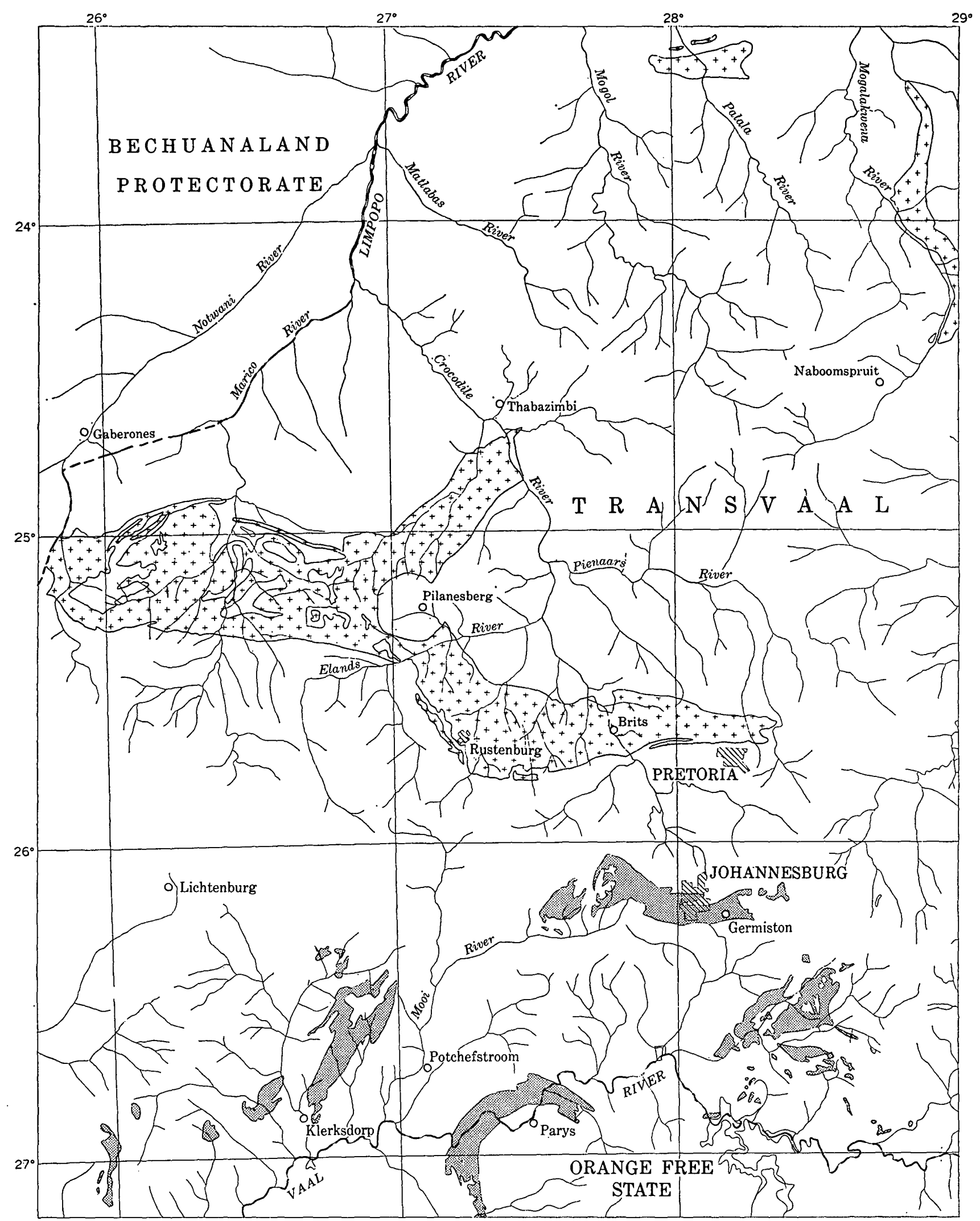

FIGURE 3.-Norite and differentiated ultrabasic rocks of the Bushveld igneous complex and the Witwatersrand System, Transvaal and Orange Free State, Republic of South Africa. 
$29^{\circ}$

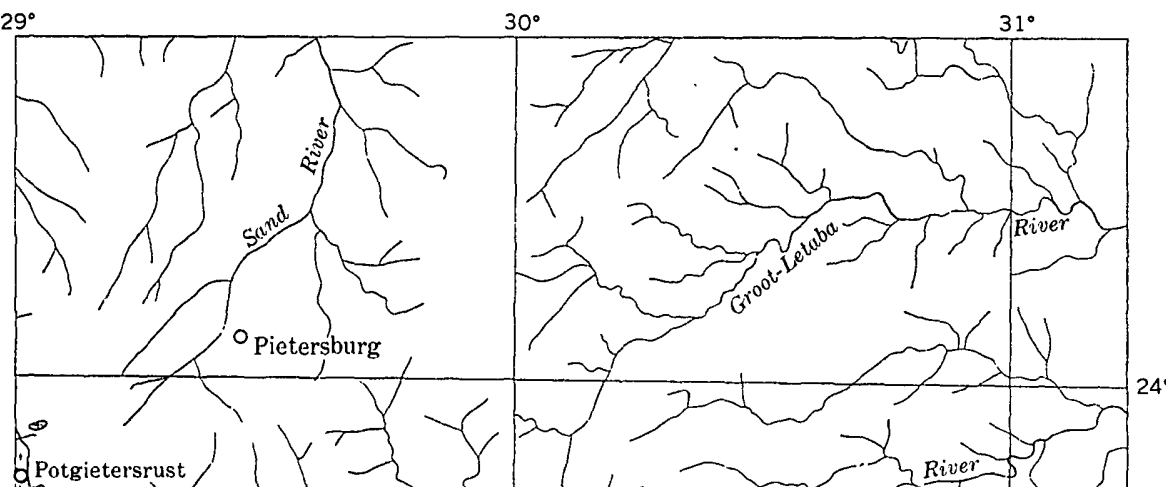

Potgietersrust
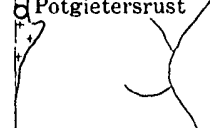
(1)
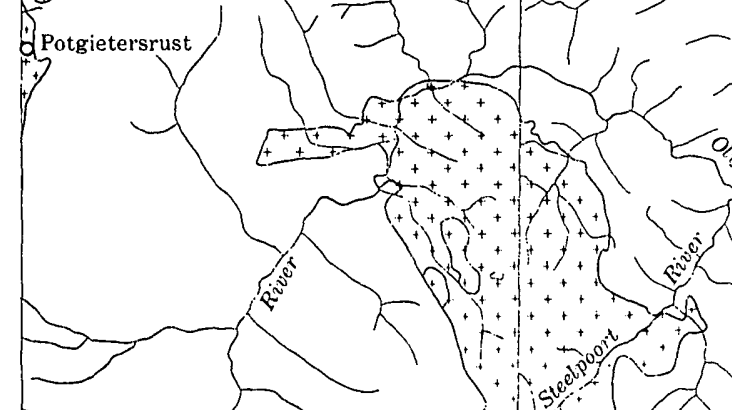

$\rightarrow \rightarrow$
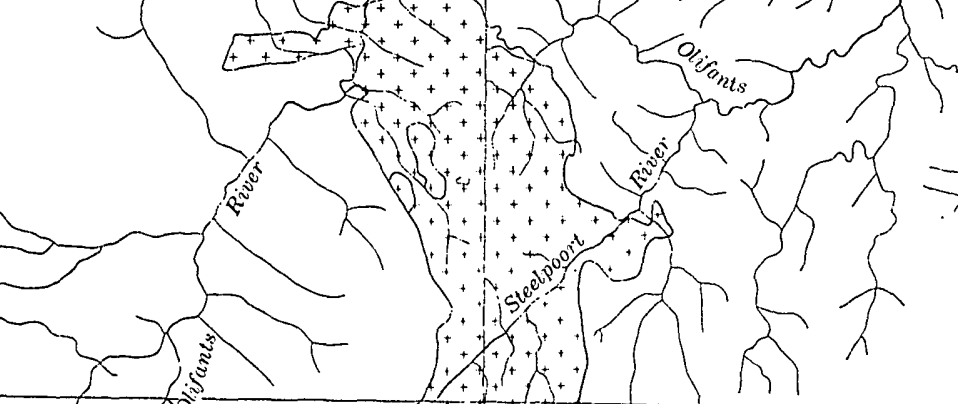

$++$
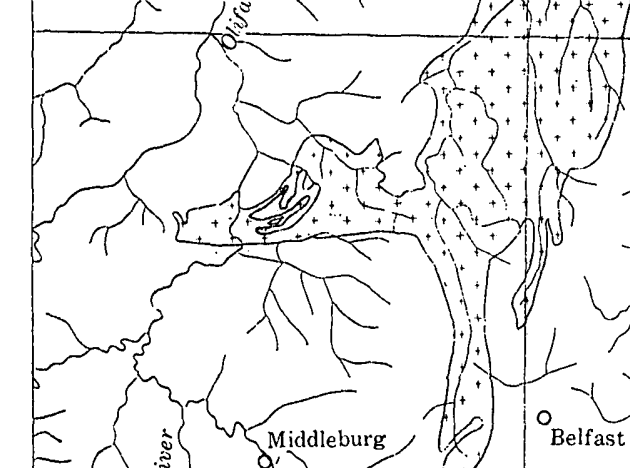

$+10$

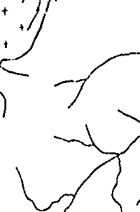

oydenburg
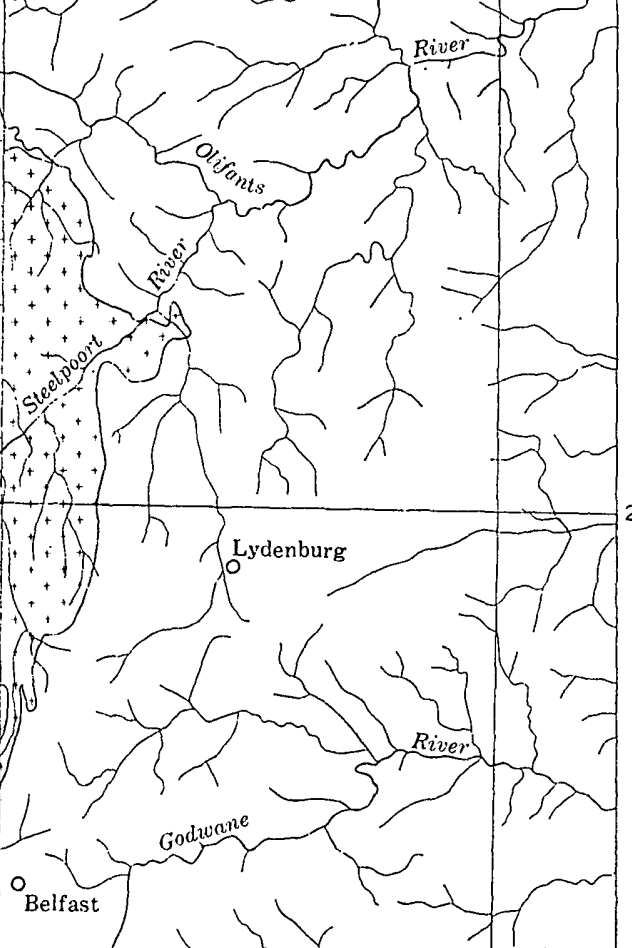

O Belfast
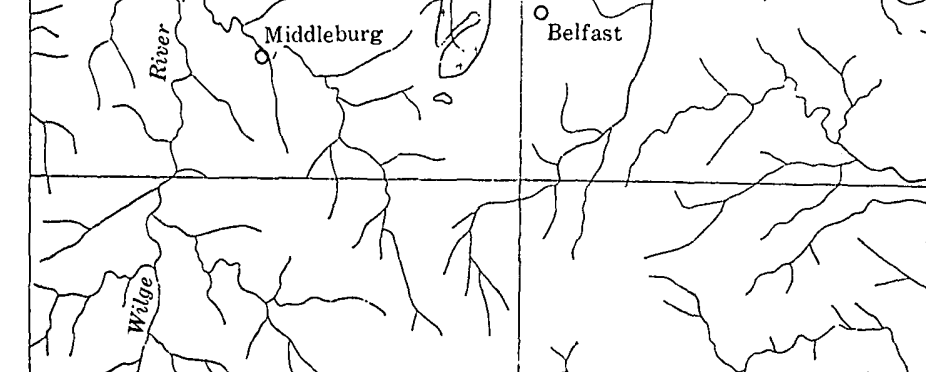

EXPLANATION

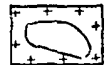

Norite and differentiated ultrabasic rocks of the Bushveld igneous complex

inpatterned areas within unit indicate rocks of the Transvaal System.

\section{$\sqrt{1 / 2}$}

Witwatersrand System

Unpatterned areas within unit indicate rocks of Transvaal System

Contact, approximately located

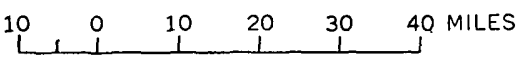


MAGMATIC SEGREGATES

The mineral deposits formed by magmatic segregation have been divided by Wagner (1929, p. 49) into the seven following types.

Classification of magmatically segregated platinum deposits

A. Upper noritic rocks:

1. Deposits in quartz-bearing anorthositic norite.

2. Deposits in a medium-grained feldspar-rich spotted norite.

3. Deposits in a rather coarse-grained feldsparrich diallage-norite.

B. Lower noritic rocks:

4. Deposits of the Merensky type that occur above and below the main Merensky zone.

5. The main Merensky zone, as developed in the Rustenburg, Pretoria, Lydenburg, Pietersburg, and Potgietersrust districts. The mineralized rocks fare pseudoporphyritic pyroxenitic diallage-norite, feldspathic harzburgite and chromitite.

6. Deposits in a fine-grained pyroxenitic diallagenorite, merging into coarse-grained feldspathic bronzitite and bronzitite.

7. Deposits in bronzitite.

The first type of the magmatic differentiates is illustrated by a number of deposits about 35 miles northnorthwest of Middleburg. The mineralized rock consists of irregular segregations of light-colored anorthositic quartz-bearing norite in a dark-colored diallage norite. The largest of these deposits has been proved by underground exploratory work to be of considerable size, but it has not been mined. Labradorite, the principal rock-forming mineral of the light-colored norite, is intergrown with diallage, a little quartz, and less chlorite. The ore minerals are chalcopyrite, pentlandite, and pyrrhotite, which appear as small specks scattered rather uniformly throughout the rock. Sperrylite, the only recognized platinum mineral, occurs in minute, brilliant, cubo-octahedra. The tenor in platinum is given as a maximum of 0.65 troy ounce per ton of ore.

The second type of magmatic differentiate is illustrated by the ores near the eastern limit of the noritic intrusive, southeast of the Steelport River. These deposits comprise at least five zones in the upper part of the norite which consists of irregular masses of medium-grained spotted feldspar-rich sulfidic norites that either underlie or are enclosed in lenses of spotted anorthosite. The mineralized rock is dominantly a granular aggregate of labradorite, intergrown with some bronzite, and less hornblende and diallage. The sulfides occur interstitially as irregular intergrowths of pyrrhotite, nickeliferous pyrite, pentlandite, and chalcopyrite. These mineralized zones are rarely longer than 8 feet nor thicker than 18 inches, and conform structurally with the general attitude of the country rock, which dips $15^{\circ}$ west-northwest. The tenor in platinum ranges from 0.02 to 0.12 ounce per ton, and the deposits lack economic value.

The third type of ore deposit occurs in the same general vicinity as the one just described. The ores consist of small irregular bodies of coarse-grained feldspar-rich sulfidic diallage norite, enclosed in medium-grained spotted norite. The sulfide-bearing norite commonly encloses a thin seam of magnetite, and a great stratiform segregation of titaniferous magnetite lies a short distance higher in the sequence. The orecarrier is a lustrous blue-green rock that consists of large tabular crystals of labradorite, anhedral grains of green diopside with rodlike inclusions, anhedral crystals of bronzite, and small grains of magnetite. Sulfides ranging in size up to 0.8 centimeter in maximum diameter are irregularly distributed in the rock. The character of the platinum minerals is not known, but they are believed to occur in the sulfides. A sample of the ore, taken over a thickness of 42 inches, had a tenor of 0.27 ounce of platinum per ton. This deposit is no longer worked.

The fourth type represents ores similar to those of the Merensky zone, which occur in the igneous sequence above and below the latter zone. They differ from the true Merensky zone in being lenticular and in having lower tenors in the platinum metals. Some of these ores were formerly mined.

A magmatic deposit of the sixth type occurs about 11 miles northwest of Potgietersrust, in association with the west-dipping dikelike extension of the noritic lopolith. This deposit is a thick sheet of finegrained pyroxenitic diallage norite, merging locally into coarse-grained bronzitite and feldspathic bronzitite, and was traced for 1,700 feet. The norite intrudes beds of ironstone and quartzite and includes xenoliths of these rocks. The sulfide mineralization is sporadic, and platinum is erratically distributed in the ores. For these reasons, the deposit has no economic significance.

The seventh type of deposit, which occurs only in the Rustenburg district, consists of isolated pipe- and irregular-shaped masses composed partly of disseminated sulfides, partly of sulfides poikilitically intergrown with rock-forming minerals, and partly of massive sulfides. The enclosing country rock is bronzitite, with enclosed lenses of harzburgite and anorthositic norite. Small amounts of palladium and less 
platinum are present in the sulfides, and also in sperrylite. These deposits are not rated as important sources of the platinum metals.

Merensky zone

The Merensky zone is an exceedingly persistent igneous sheet that lies near the top of Wagner's differentiated or critical zone. It therefore lies approximately 9,000 feet below the top of the lopolith in the Rustenburg district, and about 6,000 feet above its base. The Merensky zone has been traced intermittently for 140 miles in the Rustenburg and Pilandsberg districts, for 70 miles in the Lydenburg district, and for 40 miles in the Potgietersrust district. This zone has been prospected and proved to contain workable ore for 70 miles along its outcrop at the western end of the lopolith, where the Rustenburg and Union mines are located. Notwithstanding the general continuity of this sheet along its strike, marked differences exist in its thickness and petrographic cross section. A description of this zone throughout its entire length is far beyond the scope of this report, but such details, if needed, will be found in the volume by Wagner (1929).

Another well-known zone, at stratigraphic distances of 400 to 1,000 feet above the Merensky zone, consists of an anorthosite which is particularly resistant to weathering, forming large residual boulders at the surface. This is regarded as a valuable horizon marker in prospecting.

The Merensky reef, also called the Merensky platinum reef, where it exists as a distinct horizon, is a relatively thin sheet of coarsely crystalline pyroxenite with a pegmatitic habit that lies near the base of the Merensky zone. This reef, with a thickness of 1 to 2 feet, is the principal source of the platinum metals that are being recovered in present mining operations. The tenor in platinum metals, however, is somewhat higher in the upper than in the lower part of the reef. At the base of the reef is a seam of chromite, with a mean thickness of three-fourths of an inch, and at its top is a similar but thinner seam of chromite. These are called the lower and upper chrome bands and have high tenors in platinum, but are too thin to influence the average tenor greatly. Platinum metals extend upward from the Merensky reef for some inches into the overlying pyroxenite, and similarly downward into an underlying anorthosite.

The Merensky zone ranges in thickness from 2 to 35 feet. In general, this igneous sheet is a dark-colored norite, but the petrographic character varies both along the strike and across it. The relative amounts of pyroxene and feldspar are inconstant, and with an increase in feldspar the rock grades into anortho- sitic norite and anorthosite; with an increase in pyroxene it grades into pyroxenite. Locally the norite becomes peridotitic. The rock adjacent to the hanging wall is generally a light-colored spotted norite, composed of bronzite and diallage in a matrix of feldspar. Directly above the Merensky zone is a fine-grained pyroxenite, which by some writers is called the Merensky pyroxenite. This is overlain by anorthositic gabbro, which is overlain by a mottled or spotted anorthosite. These three sheets, with a combined thickness of 25 feet, are succeeded upward by another pyroxenite, with a thickness of 8 to 22 feet, which is called the Bastard reef. This well-known horizon resembles in several respects the Merensky zone, and even has a thin seam of chromite at its base. But it is either barren of platinum metals, or contains at most only very small amounts of them. Anorthosite commonly forms the base of the Merensky zone.

Two platinum lode mines, controlled by the Rustenburg Platinum Mines, Ltd., are now being operated in the Merensky zone of the Transvaal. The older of these mines, called the Rustenburg (formerly the Waterval) mine, is about 7 miles east of Rustenburg; the other, called the Union mine, is about 48 miles $\mathrm{N}$. $5^{\circ} \mathrm{W}$. of Rustenburg. The geological and other data on these deposits, as presented below, have been obtained from papers by the technical advisers to the Rustenburg Platinum Mines, Ltd. (1957), by Coertze (1958), by Cousins (1959 a, b, c), by Beath, Cousins, and Westwood (1961), and by Beath, Westwood, and Cousins (1961). Certain minor discrepancies in these papers have been resolved by the writer, according to his best judgement.

The ore body mined at the Rustenburg mine comprises the Merensky platinum reef with a thickness of about 12 inches, 8 to 9 inches of the overlying pyroxenite, and 8 to 9 inches of the underlying anorthosite making a total thickness of 28 to 30 inches. This platinum-bearing horizon is so regular that, over the last 10 years, the average stoping thickness of ore has been $281 / 2$ inches. The strike of the ore body is eastwest, with a dip of $9^{\circ} 30^{\prime} \mathrm{N}$., and mining has now reached a vertical depth of about 1,000 feet-a depth corresponding to about 6,000 feet down the dip. The extent of the mine along the strike is about 8 miles. Dikes and faults are rare, but at both mines there are roughly elliptical "potholes" of unknown origin that extend downward from the base of the Merensky reef, with diameters ranging from 20 to 100 feet and depths of 5 to 6 feet. Generally the ore at the bottoms of these potholes can be recovered. There are also subcircular dome-shaped masses, known as "koppies," which project upward from the anorthosite on 
the footwall, and may be high enough to replace entirely the Merensky reef, and rarely to extend upward into the overlying pyroxenite. The rocks bounding the potholes and koppies are unfolded. Potholes and koppies are more prevalent at the Rustenburg than at the Union mine.

The ore body at the Union mine is markedly different from that at the Rustenburg mine. The pegmatitic pyroxenite which constitutes the Merensky zone has a thickness ranging from 10 feet in the southwestern part of the property to 20 feet in the northeastern part. The ore body here strikes northeast and dips about $21^{\circ} \mathrm{SE}$. Up to 1965 , the mine had been worked to a depth of about 700 feet - a depth corresponding to a distance of 2,000 feet down the slope of the intrusive and for a distance of $2 \frac{1}{2}$ miles along its strike. The platinum metals occur both at the top and at the bottom of this thick sheet but are concentrated near its upper contact, so that it is generally unprofitable to work the leaner ore at its base. Potholes in the Union mine are larger than in the Rustenburg mine, with diameters ranging from 200 to 700 feet and with correspondingly greater depths. Any ore that occurs at their bases cannot readily be recovered.

The platinum minerals at both mines are sperrylite, braggite, stibiopalladinite, and laurite, which occur as discrete grains and intergrowths in disseminated sulfides. The platinum metals probably occur also as molecular intergrowths replacing certain cations in the sulfides. Some native platinum metals are recovered, together with a little native gold. The platinum metals are mainly ferroplatinum, containing from 10 to 30 percent iron. Native ferroplatinum is more plentiful at the Union than at the Rustenburg mine, but the exact amounts or proportions have not been ascertained. The sulfides comprise chalcopyrite, pyrrhotite, pentlandite, nickeliferous pyrite, cubanite, graphite, millerite, and violarite. The tenor of the ore in platinum metals, in the stretch from Rustenburg to Brits, is reported to range from 0.25 to 0.35 ounce per ton. The tenors of similar lodes in the Lyndenburg and Potgietersrust districts are lower. These metals are strongly concentrated in the bounding chromite seams, particularly in the lower chrome band, where a tenor of 0.6 ounce per ton has been reported. The nickel and copper produced have a constant ratio to the amount of platinum metals recovered, but this ratio is higher at the Rustenburg than at the Union mine. In both mines, the ratio of nickel to copper is 1.8:1.

The oxidation of the platinum-bearing sulfides is a matter of interest. The footwall of the Merensky zone is composed at many places of bronzite and less diallage, sparingly but rather uniformly included in a matrix of labradorite-bytonite. Within the zone of oxidation, beneath the present level of ground water, this rock is mottled by streaks of limonite for a depth ranging downward as much as $21 / 2$ feet below the Merensky zone. This weathered zone contains specks of sulfides and small amounts of platinum metals. At the Rustenburg mine the zone of oxidation extends about 700 feet down the dip, a distance corresponding to a vertical depth of about 120 feet in general, in the Rustenburg district, this depth ranges from 70 to 140 feet. The fact that the top of the present water table, however, is from 40 to 60 feet below the surface shows that the visible oxidation of the ore was accomplished when the water table was lower than at present, presumably during an earlier and more arid climate. The composition of the platinum metals in the sulfide ore and in the weathered ore are notably different. Two analyses from the Rustenburg district, which are the means of four analyses published by Wagner (1929, p. 110), have been recomputed to 100 percent to show these differences (table 19). The platinum: palladium ratios in these two analyses are respectively $3: 1$ and $5.7: 1$. It is clear that a part of the palladium, and possibly some of the rhodium, was dissolved by mineralized ground water. This process relatively enriched the more resistant platinum.

TABLE 19.-Composition, in percent, of platinum metals in sulfide and oxidized ores, Rustenburg district

[N.D., no data]

Sulfide ore Oxidized ore

\begin{tabular}{|c|c|c|}
\hline $\begin{array}{l}\text { Platinum } \\
\text { Iridium } \\
\text { Iridium and osmium } \\
\text { Rhodium } \\
\text { Palladium }\end{array}$ & $\begin{aligned} & 69 . 74 \\
& \text { N.D. } \\
& \text { 3. } 08 \\
& \text { 4. } 10 \\
& 23.08\end{aligned}$ & $\begin{array}{r}\text { 79. } 92 \\
1.29 \\
2.84 \\
1.92 \\
14.03\end{array}$ \\
\hline Total & 100.00 & 100.00 \\
\hline
\end{tabular}

The preceding statements, which accept the origin of the platiniferous horizons in the Bushveld complex as differentiated igneous sheets, are now being reexamined more closely by workers at the Union and Rustenburg mines, and in nearby areas where data based upon drilling on a large scale is being done. Coertze $(1958$, p. $387-400)$ has proposed that each of the basic types of the Bushveld igneous complex, including pyroxenite with chromite seams, anorthosite, norite, porphyritic, pyroxenite, pegmatitic pyroxenite, gabbro, ferrogabbro, dunite, and magnetite, represents a separate intrusion. More recently it has been stated by Beath, Cousins, and Westwood $(1961$, p. 2$)$ that recent geophysical and collateral evidence tend to contradict 
the lopolithic concept of the noritic rocks of the Bushveld igneous complex. Instead it is inferred that the eastern and western limbs of this intrusive represent separate T-shaped curved dikes that extend to great depths, and that basic and ultrabasic rocks do not underlie the central part of the basin. The cited authors appear to agree with the interpretation of Coertze, but also suggest as an alternative hypothesis that these rocks may be of extrusive origin, which would account for the phenomenal regularity of the successive sheets and for the absence of crosscutting by dikes. It is admitted, however, that the true genesis of the Bushveld igneous complex remains still within the realm of speculation.

Chemical analyses

The mean ratios of the platinum metals from the lodes of the Transvaal are much better known than the ratios from the Sudbury district. The sales of platinum metals, both from the lodes and from the Witwatersrand lithifield placers, have been published regularly by the Department of Mines and Industries, of the Republic of South Africa, and have been quoted annually by the U.S. Bureau of Mines in the sequence of Minerals Yearbooks. The following data on the lodes comprise those of 20 years in the interval 1929-56, and therefore may include for a few years some of the platinum metals from mining operations now discontinued, but in general these data represent the production from the Rustenburg and Pilandsberg districts. These records, recomputed to simulate analyses, are shown in table 20.

The ratio of platinum to palladium in the Merensky zone is reported by Wagner $(1929$, p. 129) to range from $6.5: 1$ to $1.6: 1$ and is shown in the Potgietersrust

TABLE 20.-Composition, in percent, of platinum metals, mainly from Rustenburg district

[N.D., no data]

\begin{tabular}{|c|c|c|c|c|c|c|c|c|c|c|c|}
\hline & 1929 & 1930 & 1931 & & 1934 & 1935 & 1936 & 1937 & 1938 & 1939 & 1940 \\
\hline $\begin{array}{l}\text { Platinum } \\
\text { Iridium } \\
\text { Osmium and iridium } \\
\text { Ruthenium } \\
\text { Rhodium } \\
\text { Palladium }\end{array}$ & $\begin{array}{r}82.92 \\
.56 \\
.46 \\
.59 \\
1.10 \\
12.77\end{array}$ & $\begin{array}{r}80.96 \\
.24 \\
.45 \\
.47 \\
.64 \\
12.51\end{array}$ & $\begin{array}{r}\text { 74. } 99 \\
.21 \\
.08 \\
\text { 1. } 39 \\
.15 \\
15.96\end{array}$ & & $\begin{array}{r}86.82 \\
.01 \\
.01 \\
41 \\
\text { N.D. } \\
\text { 12. } 00\end{array}$ & $\begin{array}{r}\text { 79. } 83 \\
.08 \\
.02 \\
.08 \\
\text { N.D. } \\
\text { 13. } 59\end{array}$ & $\begin{array}{r}\text { 77. } 75 \\
.05 \\
-9 . \\
\text { N.D. } \\
\text { 1.5. } 82\end{array}$ & $\begin{array}{r}\text { 77. } 08 \\
.06 \\
.14 \\
\text { N. } 51 \\
\text { 16. } 70\end{array}$ & $\begin{array}{r}\text { 72. } 53 \\
.20 \\
.12 \\
\text { 1. } 72 \\
\text { N.D. } \\
\text { 19. } 78\end{array}$ & $\begin{array}{r}\text { 78. } 20 \\
.13 \\
.08 \\
\text { 1. } 20 \\
\text { N.D. } \\
\text { 16. } 33\end{array}$ & $\begin{array}{r}\text { 66. } 27 \\
.42 \\
.22 \\
2.20 \\
.64 \\
25.71\end{array}$ \\
\hline \multirow[t]{2}{*}{ Total $\ldots$} & 98.40 & 95. 27 & 92.78 & & 99.25 & 93.60 & 94.53 & 94. 49 & 94. 35 & 95.94 & 95.46 \\
\hline & 1944 & 1845 & 1947 & 1948 & 1949 & 1951 & 1952 & 1954 & 1955 & 1956 & $\begin{array}{c}\text { Adjusted } \\
\text { mean }\end{array}$ \\
\hline $\begin{array}{l}\text { Platinum } \\
\text { Iridium } \\
\text { Osmium and iridium } \\
\text { Ruthenium } \\
\text { Rhodium } \\
\text { Palladium }\end{array}$ & $\begin{array}{r}\text { 63. } 58 \\
.38 \\
.03 \\
4.39 \\
1.12 \\
27.01\end{array}$ & $\begin{array}{r}59.72 \\
.74 \\
.12 \\
4.10 \\
1.79 \\
28.59\end{array}$ & $\begin{array}{r}\text { 77. } 08 \\
.06 \\
.14 \\
.51 \\
\text { N.D. } \\
\text { 16. } 70\end{array}$ & $\begin{array}{r}\text { 69. } 17 \\
.47 \\
.09 \\
1.29 \\
2.57 \\
22.03\end{array}$ & $\begin{array}{r}\text { 61. } 27 \\
.30 \\
.10 \\
\text { 1. } 80 \\
\text { 3. } 32 \\
29.21\end{array}$ & $\begin{array}{r}68.89 \\
.31 \\
.11 \\
1.51 \\
1.79 \\
23.14\end{array}$ & $\begin{array}{r}\text { 66. } 27 \\
.13 \\
.11 \\
1.34 \\
2.39 \\
26.40\end{array}$ & $\begin{array}{r}\text { 78. } 18 \\
\text { N.D. } \\
.03 \\
\text { 1. } 62 \\
2.66 \\
13.81\end{array}$ & $\begin{array}{r}60.98 \\
\text { N.D. } \\
.08 \\
.59 \\
2.38 \\
33.35\end{array}$ & $\begin{array}{r}69.50 \\
\text { N.D. } \\
\text { N.D. } \\
.50 \\
2.30 \\
24.30\end{array}$ & $\begin{array}{r}75.06 \\
.27 \\
.13 \\
1.41 \\
2.15 \\
20.98\end{array}$ \\
\hline Total $\ldots \ldots$ & 96.51 & 95.06 & 94.49 & 95.62 & 96.00 & 95.75 & 96.64 & 96.30 & 97.38 & 96.60 & 100. 00 \\
\hline
\end{tabular}

district to be as low as $1.3: 1$. Table 20 shows a ratio for the Rustenburg district of $3.6: 1$, which is substantially different from that at Sudbury, where it is about 1.1:1. The data on the relative prevalence of rhodium and ruthenium are not as dependable as could be desired, but according to table 20, the amount of rhodium exceeds that of ruthenium, though rhodium is much less plentiful than at Sudbury. The proportions of the metals recovered from the placers of Goodnews Bay, Alaska, and from the Uralian placers, as shown respectively on pages 59 and 88 , are markedly different from those recovered from the lodes of the Transvaal and Sudbury. This fact constitutes a significant difference that distinguishes the native platinum metals of the peridotites and perknites from the platinum metals recovered from the platinum minerals of lodes.

\section{CHROMITITE ORES}

The more important platinum-bearing chromitite ores of the Bushveld complex are in the Lydenburg district, though similar bands have also been recognized in the Rustenburg district. Two principal zones of platiniferous chromitite, called the upper and lower chromitite horizons which lie in the lower fourth of the norite lopolith, are present in both districts. A third band, lying between the upper and lower horizons, has also been found in the Rustenburg district. These and other deposits of chromite are widely and persistently distributed along the strike of the intrusives in both districts, ranging in length from 3 feet 
to several miles and in thickness from 1 inch to 14 feet. The fact that a typical deposit in the upper horizon, about 50 miles N. $28^{\circ} \mathrm{W}$. of Lydenburg, occurs about a mile east of the outcrop of the Merensky zone and about 1,200 feet stratigraphically below the latter indicates an areal dip of $13^{\circ}$ westward. In this deposit are two lenses of chromitite, with thicknesses of 2 and 3 feet, separated by 17 feet of bronzitite and norite.

The platinum-bearing chromitite consists generally of oval-shaped grains of bronzite crowded with minute poikilitic inclusions of chromite in a scanty matrix of larger included grains. Locally the rock is interspersed with irregular patches and streaks of coarse-grained chromite and picotite. The rock also contains minor amounts of diallage and calcic plagioclase. The content of $\mathrm{Cr}_{2} \mathrm{O}_{3}$ ranges in these deposits from 38 to 47 percent.

Native platinum metals characterize the chromitite deposits. These commonly occur in very thin plates and in slender wires of which some have only the thickness of a hair. Analyses have shown that platinum predominates over palladium, but at one deposit in the Lydenburg district, palladium constituted 55 percent of the platinum metals. No analyses are available that give the tenors of iridium, osmium, ruthenium, and rhodium. Tenors of platinum metals in chromitite are stated by Wagner (1929, p. 93-95) to range from 0.06 to 5.75 ounces per ton, but no average tenor may be cited. These deposits were intensively prospected in 1925 and 1926, but since the discovery of the Merensky reef in the Rustenburg district, no further attention has been given to them.

\section{DUNITE ORES}

Platiniferous dunites and related rocks have been found at many sites in the Lydenburg and Rustenburg districts. These deposits have a stratiform range of 2,000 feet in the lower part of the noritic lopolith, mainly below the Merensky zone, but a few occur above that horizon in the Lydenburg district. The most important deposits, however, lie between the upper and lower chromitite horizons.

These deposits are divided by Wagner (1929, p.5152) into three types which depend primarily upon the nature of the olivine in the dunite. These varieties of olivine are, first, the normal type, wherein the ratio of $\mathrm{Mg} 0$ to $\mathrm{Fe} 0$ ranges from $12: 1$ to $2.5: 1$; second, hyalosiderite, with a $\mathrm{Mg} 0-\mathrm{Fe} 0$ ratio ranging from $2.5: 1$ to 1.1 ; and third, hortonolite, in which the $\mathrm{Mg} 0$ $\mathrm{Fe} 0$ ratio ranges from $1: 1$ to $1: 2$. The first type is characteristic of the dunites of the Ural Mountains and occurs only sporadically in the Transvaal; the second type is exemplified by only one important deposit, known as the Driekop deposit, which is about 32 miles N. $28^{\circ} \mathrm{W}$. of Lydenburg; but more than 60 occurrences of ores of hortonolite dunite are known, both in the Lydenburg and Rustenburg districts. The two most important deposits of platiniferous hortonolite dunite, called the Mooihoek and Onverwacht lodes, occur about 3 and 6 miles respectively south of the Driekop deposit.

The Driekop deposit is essentially an intrusive core of platinum-bearing hyalosideritic dunite, enclosed in a much larger pipe of nearly barren dunite. The workable surficial area measures approximately 80 by 60 feet, but narrows somewhat with depth. The dip of the dunite core and probably also of the dunite pipe is about $77^{\circ} \mathrm{NE}$. The platinum-bearing core has been followed downward to a depth of 460 feet without any great constriction. The ore body consists dominantly of interlocking grains of hyalosiderite with a $\mathrm{Mg} 0: \mathrm{Fe} 0$ ratio of $2.4: 1$, together with small amounts of large greenish-gray crystals of diallage and also small anhedral grains of magnetite. Locally the diallage is sufficiently plentiful that the rock becomes a wehrlite.

A recent study of the Driekop deposit has been made by Heckroodt (1959, p. 59-71), and it is also from the dunite at this site that Stumpfl (1961, p. 833-847) identified the nine new platinum minerals that he described. In an area of 20 square miles surrounding this deposit, Heckroodt was able to recognize five successive phases in the basic and ultrabasic rocks, which were identified in the order of their intrusion as pyroxenite, norite and related rocks, pegmatitic feldspathic pyroxenite (Merensky zone), peridotite including dunite and serpentinite, and gabbroic rocks.

The platinum metals occur mainly as native alloys, within small segregations, lenses, and irregular clumps of iron-rich dunite and wehrlite of markedly coarser grain, such that the olivine is particularly conspicuous by reflected light. Below water level, small amounts of sperrylite and cooperite are also present. Nine assays of average ore show a range in platinum metals from 0.02 to 0.53 ounces per ton, with a mean tenor of 0.17 ounce per ton. Picked samples, however, range upward to 2.7 ounces per ton. The ratios of platinum to palladium and other platinum metals have not been published.

The Mooihoek ore deposit is a pipe of platiniferous hortonolite dunite, which is nearly circular in horizontal section, with a diameter of about 42 by 51 feet. This is enclosed in a layered cylindrical pipe of dunite and serpentinite, whose surficial horizontal measurements are 700 feet from north to south and 600 to 
850 feet from east to west. The larger pipe is bounded by coarse pegmatitic diallage and feldspathic pyroxenite, which merge outward into olivine gabbro and spotted norite. The dimensions cited for the smaller pipe are those which delimit the workable ore, rather than dimensions based upon petrographic homogeneity, as the bounding dunite also contains small amounts of the platinum metals. The small platiniferous pipe of workable ore plunges $\mathrm{N} .76^{\circ} \mathrm{E}$. at an angle of $80^{\circ}$, and therefore lies nearly normal to the pseudostratification of the gabbroic country rock. This pipe is composed mainly of coarse-grained brown hortonolite dunite, which is interspersed with large clusters of black anhedral hornblende, books and aggregates of phlogopite ranging up to 6 inches in diameter, and clots and larger masses of lustrous titaniferous magnetite. Segregates of ilmenitite up to 3 feet in diameter are present. The hortonolite dunite merges rather gradually outward into the bounding olivine dunite. Pegmatitic veins composed of large crystals of diallage, phlogopite, hornblende, magnetite, and ilmenite in two systems of veins, with thicknesses from 1 inch to 4 feet, run parallel to the ore body. These veins appear to contain little platinum.

Most of the platinum metals occur in the native state, but Wagner $(1929$, p. 219) records the fact that platiniferous sulfides occur in veins and chromitic schlieren along the hanging. wall of the large pipe. Sperrylite and cooperite have also been identified in the main ore body below water level. The sulfides include pyrrhotite, pentlandite, and a little chalcopyrite. The tenor of platinum in the workable pipe of the Mooihoek mine ranged from 0.01 to 1.0 ounce per ton of ore, with an average tenor of about 0.13 ounce. The platinum metals occur throughout the workable pipe, but they increase from the margin of the pipe inwards to the center, where they are highest. Thus, a winze sunk down the middle of the pipe showed an average value of 2.1 ounces per ton, whereas the mean tenor for the 350-foot level of the mine was 0.34 ounce. The character and percentages of the six platinum metals have not been recorded. A section of the mine, published by Wagner $(1929$, p. 72$)$, shows the underground workings down to the 450foot level and crosscut. Mining has been discontinued.

The Onverwacht mine was located on another pipe, similar to that at the Mooihoek mine. This pipe is an irregular but roughly parsnip-shaped segregate, or possibly intrusive, of hortonolite dunite and hortonolite wehrlite, within a much larger, steeply inclined pipe of olivine dunite that bears a transgressive or discordant relationship to the surrounding country rock. The olivine dunite at and near the surface is altered to serpentinite, which is cut by a network of veins and seams of magnesite. These secondary features disappear in the mine below a depth of 300 feet. The hortonolitic ore body crops out as a roughly circular area of coarse-grained rock with a radius of about 25 feet, surrounded by a finer grained shell of the same rock with a thickness of about 5 feet. This pipe plunges S. $28^{\circ} \mathrm{E}$. at an angle of about $78^{\circ}$ which is roughly normal to the stratiform sheets of bronzitite that constitute the country rock. Wagner $(1929$, p. 64) believes that these stratiform sheets were intruded in a horizontal position, and therefore that the pipes of olivine dunite, hortonolite dunite, and wehrlite had originally a vertical attitude. The radius of the hortonolitic pipe increased downward for a short distance, and then decreased to the 350-foot level of the mine, where it split into three smaller bodies. The largest of these roots continued downward to and below the 750-foot level, where it had a radius of about 11.5 feet. The other two roots disappeared below the 450 -foot level.

The principal or central part of the ore body consists of rather coarse-grained hortonolite dunite and wehrlite, wherein the hortonolite occurs as crystals that range in size up to a maximum diameter of 2 inches. Black anhedral crystals of hornblende are also present, and the rock is interspersed with patches and schlieren of phlogopite in leaves up to 8 inches in diameter. On the 200 -foot level the ore contained clots of titaniferous magnetite, and on the 250-foot level and elsewhere in the mine, the ore included large xenoliths and slabs of chromitite.

The platinum metals are so distributed that the tenors are highest in the central or axial zone of the pipe and decrease toward its periphery. In the upper levels the central part of the pipe had an average tenor of 1 ounce of platinum metals per ton of ore. Another zone of enrichment was in and along the borders of the bodies of chromitite; and along one such contact, ore was found that had a tenor of 55 ounces per ton. The best average ore was on the 250-foot level, where the mean tenor was 0.92 ounce per ton. With depth, however, the ore grew leaner; and between the 550-foot and 700-foot levels, the lode was barren, though workable ore was again found between the 700 -foot and 800-foot levels. Mining has been discontinued.

Native platinum alloys constitute most of the platinum metals recovered from the upper levels of the Onverwacht mine, but in the lower levels about 25 percent of these metals come from sperrylite and cooperite. The number and character of the platinum alloys have not been determined, but two inferior analyses of some of the native metals have been pub- 
lished by Wagner (1929, p. 19). These samples were handpicked, and therefore the base metals may be regarded mainly as dross. The mean of these two analyses, with and without the dross, are shown respectively as $A$ and $B$ in table 21.

TABLE 21.-Analyses, in percent, of platinum metals at Onverwacht mine

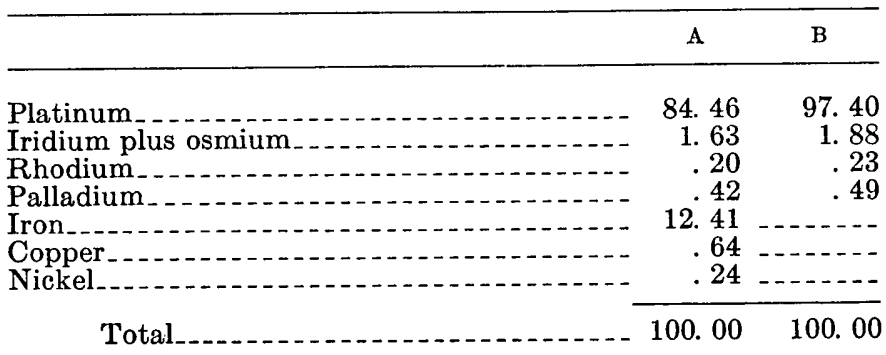

PNEUMATOLYTIC, H YDROTHERMAL, AND

CONTACT METAMORPHIC ORES

Pneumatolytic and hydrothermal ores are best exemplified by a group of deposits in the Waterberg district, about 8 miles west-northwest of Naboonspruit. These consist of brecciated quartz lodes that lie in felsite and felsitic tuff, close to the Red granite, in the upper part of the Bushveld igneous complex. The principal one of these lodes and another lode branching from it were worked in 1924-26, but mining was finally discontinued because the platinum ores, though of high tenor, were erratically distributed with much ore of very low grade between the rich ore shoots.

The principal lode has a thickness of 6 to 60 feet, and can be traced at the surface in a direction about $\mathrm{N}$. $55^{\circ}$ E. for $21 / 2$ miles. The dip of the ore body is from $60^{\circ}$ to $75^{\circ} \mathrm{SE}$. A branch from the main lode has a thickness of 4 to 30 feet, and is traceable east-northeast for a distance of about 1,240 feet. Some of the richest ore came from this branch lode. Both the main lode and its branch consist of closely spaced stringers of quartz, separated by irregular bodies of felsite. The ore consists of opaque white quartz in a comb structure with the crystals oriented normal to the walls. Other phases of the ore led to the conclusion that there were at least four stages of brecciation and deposition of quartz and chalcedony. The ore minerals are specularite and other iron oxides, sericite, chromiferous chlorite, kaolin, and pyrolusite.

Native platinum alloys occur in these ores in grains ranging in size from 0.04 to 0.6 millimeter. A part of the platinum metals are intergrown with specularite; another part of later origin is embedded in iron oxide derived from the oxidation of pyrite. Chemical analyses indicate that the ratios of platinum to palladium in the main and branch lodes are respectively $13: 1$ and $1.6: 1$. The other platinum metals were appar- ently not identified, but may be present in small amounts. The tenors in gold range from 0.4 percent in the main lode to 3.0 percent in the branch lode, so that these are platinum ores with gold as merely a small byproduct. The tenor of the platinum metals in high-grade ore shoots was remarkably high. Ore taken over a stretch of 50 feet in the main lode, over a width of 20 inches, had a tenor in platinum metals of 5.4 ounces per ton, and for the same distance along the branch lode, over a width of 35 inches, the ore had a tenor in platinum metals of 51 ounces per ton. Picked samples had still higher values.

The genesis of these siliceous platinum ores is problematical. The brecciation and the ore minerals led to a belief that they were formed at no great distance below the surface initially as pneumatolytic deposits and were followed in the waning stages of mineralization by hydrothermal deposition. Hot springs are still present in the vicinity of these lodes. The general character of the ores suggests their derivation from an underlying persilicic intrusive, but the presence of chromitiferous chlorite suggests that the ores may have come from basic or ultrabasic intrusives. A composite origin is strongly suggested. Siliceous lodes that contain platinum are known elsewhere in the world, and in fact, 23 such occurrences are tabulated on page 98 of this report. Most of these deposits, however, are gold-quartz veins, with a byproduct of platinum metals.

A contact metasomatic deposit occurs near the magmatic deposit 11 miles northwest of Potgietersrust, that was described above. This ore body is in the socalled Dolomite series, which is that part of the Transvaal system which directly underlies the Pretoria series. The ore deposit consists of several zones of crushed dolomite in a thick bed of banded ironstone, which dips steeply west, and the ore comprises lenses, eyes, and irregular bodies of graphic granite and pegmatite that contain copper and nickel sulfides, with which are associated sperrylite and stibiopalladinite. This locality is the site of the original discovery of stibiopalladinite. The deposit is considered to be too low grade for mining.

The Merensky reef has been traced intermittently for 25 miles north-northwest of Potgietersrust, and also for a short stretch south of that town. A platinum deposit that is genetically related to the Merensky reef, but not an integral part of the reef, is particularly well developed in the zone between Vaalkop and

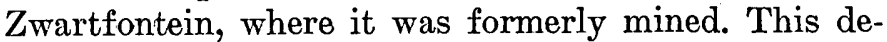
posit is a sinuous lens about 11,000 feet long and about 145 feet thick, which conforms with the pseudostratification of the intrusive sheets, and strikes generally 
north-northwest with a westward dip of about $55^{\circ}$. The ore body may be either of magmatic or contact metamorphic origin. In its southern part, where dominantly pseudomagmatic, the ore carrier is coarsegrained feldspathic pyroxenite and pegmatitic norite, with a hanging wall of coarse-grained anorthositic norite and a footwall of fine-grained rock of the same kind, but in its northern zone, the ore is composite, consisting in part of platinum-bearing bronzitite and in part of overlying and underlying silicated dolomite that is also platinum bearing. The true Merensky reef in this area lies generally above the Vaalkop-Zwartfontein body, and commonly contains few or no platinum metals.

Platinum metals occur in the southern sector in concentrations of pyrrhotite, pentlandite, chalcopyrite, and cubanite, which commonly are intergrown with hornblende both in the principal ore carrier and in the contiguous hanging wall and footwall. The platinum minerals are reported to be sperrylite and cooperite, but they include both platinum and palladium which are probably included in a number of different minerals. In the northern sector, where the ore of highest grade occurs, the sulfides that are contained in the intrusive rocks and dolomite are not uniformly distributed, but occur instead in irregular ore shoots, the locations of which require careful prospecting and sampling. Northern, central, and southern parts of the northern, or Zwartfontein, sector are described in detail by Wagner (1929, p. 168-182), and cannot very well be summarized. The central and most important ore body of this northern sector has a known length of 3,500 feet, a thickness of 90 feet, and an average dip of $70^{\circ}$ westward. For the whole ore deposit the platinum-bearing sulfides are as given above, and range in size from 1.0 millimeter to 1.5 centimeters, but in the contact metamorphic ores, the average size is about 4 millimeters. The mean tenor is platinum metals for the entire ore body is about 0.35 ounce per ton of ore, but in picked samples is as large as 2 ounces. From the concentrates produced in the last quarter of 1928, the ratios of the platinum metals, according to Wagner $(1929$, p. 111), are platinum 55.4 percent, iridium, osmium, ruthenium, and rhodium 2.4 percent, and palladium 42.2 per cent. This deposit was actively worked before the discovery of the Merensky zone in the Rustenberg district, but mining in later years has been discontinued.

\section{PLACERS OF THE WITWATERSRAND DISTRICT}

Detrital platinum has been found at numerous localities in South Africa, but none of these deposits is of present commercial value. Reference has already been made to the placers of the Lydenburg district, where platinum mining was first begun, though soon discontinued. A well-known lithified osmiridium placer is the so-called Black Reef conglomerate which is a part of the Black Reef series, that constitutes the upper 15 percent of the Transvaal system. This deposit is the site of a mine operated by the Government Gold Mining Areas (Modderfontein) Consolidated, Ltd., north of Johannesburg. The tenor of osmiridium at this property is high. The principal commercial lithified placers, however, are those of the Witwatersrand, which occur in the southern part of the Transvaal and the northern part of the Orange Free State.

\section{HISTORY AND PRODUCTION}

The gold deposits of the Witwatersrand consist of lithified placers that are mined as lode deposits. Osmiridium in this area, according to Wagner (1929, p. 33), was first identified by William Bettel in concentrates from the conglomerate (banket) of the New Rietfontein mine, in Orange Free State, in 1892. The first published description of the osmiridium was given by Young (1907, p. 17-30), but additional data were soon published by other workers. No attempt was made to save this osmiridium from 1892 to 1920 , because the gold was saved by amalgamation, which was unsuited to the recovery of platinum metals. Beginning in 1921, however, a preliminary concentration began to be made on corduroy and blankets. This process permitted a production of osmiridium. The East Rand Proprietary Mines, one of the largest goldmining companies in the world, controls 8,785 claims and has underground workings that extend $71 / 2$ miles along the strike of the auriferous reef and $31 / 2$ miles along its dip. These workings, as recently described by Anderson (1958, p. 321-325), underlie about 20 square miles of the municipalities of Germiston and Boksburg, southeast of Johannesburg. In May 1958, this mining had reached a depth of 11,000 feet, equivalent to about 1 miles below sea level. Much of the osmiridium produced in the Witwatersrand district comes from the different properties of the East Rand Proprietary Mines. The conglomerate of one of these, which is the site of the Modderfontein " $\mathrm{B}$ " mine, has been proved to have the highest tenor in osmiridium, as well as gold. Osmiridium is also recovered from properties in the West Rand.

The search for deeper deposits continues, and in 1962 the Anglo-American Corp. of South Africa, Ltd., sank a drill hole to a depth of 14,100 feet. The site of this hole was about 120 miles southwest of Johannesburg, and about 5 miles east of Bothaville, Orange Free State. This probe passed through the Karroo. Trans- 
vaal, and Ventersdorp systems to reach the gold-bearing conglomerates of the Witwatersrand system.

The output of osmiridium from the Witwatersrand, in the Transvaal and Orange Free State, has remained sensibly constant since 1925 , and is likely to continue so, because it is a byproduct of the regional production of gold, which changes little. In 1958 and 1959, however, the output of osmiridium decreased because the production of gold was curtailed, but both the osmiridium and the gold outputs are again increasing.

The production of osmiridium from the Witwatersrand from 1921 to 1960 has been shown by Quiring $(1962$, p. 101$)$ to be approximately 231,125 ounces. Adding to this the outputs for 1961-65, the total production from 1921 to 1965 inclusive is seen to be 248,625 ounces. A maximum production of 7,780 ounces was made in 1942 .

\section{GENERAL GEOLOGY}

The Witwatersrand system, consisting of bedded rocks of terrestrial origin, rests unconformably upon the rocks of the Swaziland system, which is the basal complex of this region. The Ventersdorp system, overlying the Witwatersrand system, consists dominantly of andesitic lavas and pyroclastics, and both systems are considered to be of late Precambrian age. According to Furon (1963, p. 341), the thickness of the Witwatersrand system is about 28,000 feet; and according to Coetzee (1960, p. 31-92), the thickness of these two systems is about 40,000 feet. Many local disconformities and unconformities exist in the Witwatersrand system, and the beds therefore show divergent thicknesses at different localities. The auriferous conglomerates of the Witwatersrand are ancient lithified placers, which comprise numerous strata with an aggregate thickness of about 2,000 feet and a maximum individual thickness of about 65 feet.

The rocks of the Witwatersrand system, in the Transvaal and Orange Free State, are folded into a large syncline with a major axis trending east-west, a length of about 110 miles and a width of about 45 miles. In the Johannesburg area, these rocks form the north flank of the syncline, and dip steeply south, though they flatten with depth to $30^{\circ}$. Near Parys, the synclinal structure is modified locally by a quaquaversal anticline. Owing to erosion and to the cited dome, the rocks of the Witwatersrand system crop out mainly at four separated areas, that is, near Johannesburg, Heidelburg, Parys, and in an area between Ventersdorp and Klerksdorp.

DEPOSITS

The gold and platinum of the Witwatersrand occur in thin beds of conglomerate and grit, known as reefs, which form the upper part of the Witwatersrand system. Several groups of these reefs have been recognized, including the Main Reef and Livingston group, near the base of the Upper Witwatersrand series, the Bird Reef group 1,600 feet higher in the sequence, and the Kimberly or Battery Reef group 5,000 feet stratigraphically above the Main Reef group. The principal production comes from the Main Reef group of reefs, which are mined in the Johannesburg area over an east-west extent of about 50 miles. The Main Reef group includes three productive reefs, which named from bottom to top are the Main Reef proper, the Main Reef Leader, and the South Reef. In the central part of the Johannesburg area, these three reefs are of equal size, but the Main and South Reefs extend eastward only as far as Boksburg, and the Main Reef extends westward about 11 miles. The Main Reef Leader has the greatest overall extent, and has been the principal producer of gold.

These reefs are locally persistent, but are nonpersistent over great distances, and vary considerably in thickness. Individual ore shoots have east-west and north-south dimensions that range respectively up to 5,000 and 1,000 feet. The beds of conglomerate in the Upper Witwatersrand system range in thickness from an inch to 15 feet, and in the Main Reef group from 1 to 10 feet, with thin intercalations of quartzite. The average thickness of the Main Reef, the Main Reef Leader, and the South Reef are respectively 4, 2, and 3 feet. The platinum metals are exceedingly scarce, but are most prevalent in the Main Reef Leader on the Far East Rand, less so on the West Rand, and are least plentiful in the Central Rand, where all the reefs of the Main Reef group are thickest.

Both the gold and the platinum metals are found to be most plentiful in conglomerates that have large pebbles. In the Main Reef Leader, these pebbles have a mean diameter of 2 inches, and consist mainly of quartz, with less quartzite, chert, and slate. The sandy matrix, in which the noble metals mainly occur, contains a large volume of secondary pyrite, estimated in the Main Reef Leader to constitute 3 percent of the ore. The gold occurs in minute angular crystalline aggregates, generally in direct association with the pyrite. Other ore minerals that are present in small amounts are pyrrhotite, galena, sphalerite, chalcopyrite, cobalt arsenide, uraninite, and the platinum metals. The sandy matrix has been recrystallized, with the development of secondary quartz, sericite, chlorite, chloritoid, carbon, and calcite. Tourmaline, zircon, and rutile are also present, but these are probably original accessory minerals of the conglomerates. Less resistant accessory minerals, such as the iron ores, have been de- 
stroyed in the process of recrystallization, and probably constitute the sources of the pyrite. The gold is exceedingly fine grained, and has not in general retained its original detrital form. The platinum metals, however, have resisted recrystallization and show rounded outlines, or at least rounded edges of the crystalline grains, that indicate their detrital origin.

The platinum metals are exceedingly fine grained and range in size at one mine, according to Wagner $(1929$, p. 36$)$, from 0.04 to 0.19 millimeter in diameter. At a mean diameter of 0.12 millimeter, such particles would have a value of about 0.012 cent, meaning that it would take 800,000 particles to weigh a troy ounce. The tenor of platinum metals is almost unbelievably low. Thus in the Modderfontein " $\mathrm{B}$ " banket, which contains more osmiridium than at any other mine in the Witwatersrand, the recovery, according to Wagner (1929, p. 35-36), is from 1 ounce per 1,212 tons of milled ore to 1 ounce per 9,285 tons of milled ore, or from 0.000003 to 0.0000004 percent. These figures, however, represent the amounts recovered, which probably are only about half of those actually present in the conglomerates.

The detrital origin of the gold and platinum metals of the Witwatersrand is favored by practically all South African geologists who have had a professional familiarity with these ores. The acknowledged fact of recrystallization, with solution and redeposition of the gold, however, has led some to believe that the noble metals are epigenetic and hydrothermal in origin, with sources extraneous to the conglomerate. Probably the most ambitious formulation of an epigenetic hypothesis was made by Graton (1930, 185 p.), who, notwithstanding his many contributions to the theory of ore deposits, was unfamiliar with placers. Consequently, he failed to evaluate the evidence for a detrital origin of these deposits; in particular, he overlooked the rounded and subrounded form of the grains of platinum metals. A few other geologists, in particular Davidson (1953 and 1955), have also accepted Graton's interpretation. Evidently, owing to their great resistance to the chemical processes attendant upon weathering, the grains of osmiridium, unlike the detrital gold, have not been dissolved and redeposited, but instead have maintained their original form and character. It is generally admitted that the gold and osmiridium were deposited simultaneously. It therefore follows, without the cogent collateral evidence, that all the precious metals of the Witwatersrand originated as detrital deposits.

The exact sources of the gold and platinum metals are not definitely known, though granitic intrusives within the Swaziland system, are known to be mineralized with gold, tin, and columbite, Most geologists familiar with these deposits believe that these metals were transported for a long distance from bedrock sources to the northwest or north-northwest that are now either eroded or overlapped by younger geological formations. It is certain that these bedrock sources are not directly related to the platinum-bearing intrusives of the Transvaal, as the former are millions of years older than the latter. Probably the noble metals of the Witwatersrand were contained in sediments that were transported by and deposited from a large river that built a delta close to the sea.

\section{CHEMICAL COMPOSITION}

Data are shown in table 22 on the composition of these platinum metals, which appear to be mainly osmiridium (iridosmine). It must be stated, however, that these chemical data are inferred from the records of production, and are not based directly upon chemical analyses. It is believed by Wagner $(1929$, p. 3637 ), that two or more alloys are present, and as this is probably true, it follows that the cited compositions of the osmiridium are analogous to chemical analyses of bulk samples of unseparated alloys, like most analyses of placer samples.

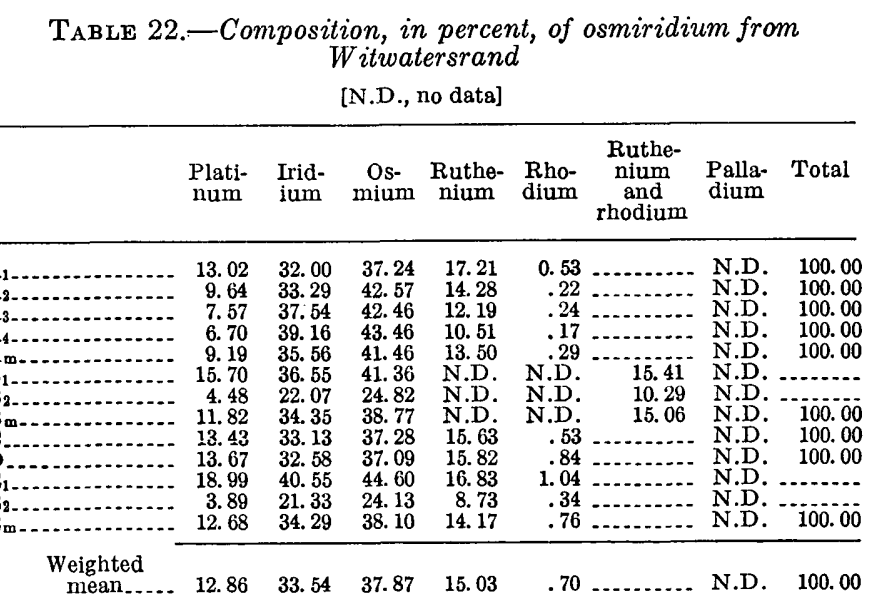

$\mathbf{A}_{1}, \mathbf{A}_{2}, \mathbf{A}_{3}, \mathbf{A}_{4}$, and $\mathbf{A}_{\mathrm{m}}$. Four analyses and their mean value that show variations in composition at four different mines (Wagner, 1929, $p$. 37). $\mathrm{B}_{2}$, and $\mathrm{B}_{\mathrm{m}}$. Two analyses and their mean value that show the maximum $\left(\mathrm{B}_{1}\right)$,
minimum $\left(\mathrm{B}_{2}\right)$, and mean $\left(\mathrm{B}_{\mathrm{w}}\right)$ compositions at most of the large mines (Wagner, 1929, p. 38).

C. The mean composition of the platinum metals sold in a period of 10 years during the period 1925-34 (Imperial Institute of Great Britain 1936, p. 60).

D. The mean composition of the platinum metals sold in a period of 17 years within the interval 1927-49 (U.S. Bureau of Mines, Minerals Yearbooks 1928-50).
E. Two analyses and their mean value that show the maximum $\left(\mathrm{E}_{1}\right)$, minimum Two analyses and their mean value that show the maximum $\left(\mathrm{E}_{1}\right)$, minimum
$\left(\mathbf{E}_{2}\right)$, and mean $\left(\mathbf{E}_{\mathbf{m}}\right)$ compositions of the platinum metals for 15 years prior to 1950 (U.S. Bureau of Mines, Mineral Yearbooks, 1950).

The bulk composition of the platinum metal of the Witwatersrand is shown in table 22. Omitting $A_{1}, A_{2}$, $A_{3}, A_{4}, B_{1}, B_{2}, E$ and $E_{2}$, and weighting $A_{m}, B_{m}, C, D$, and $\mathrm{E}_{\mathrm{m}}$ respectively at $4,2,10,17$, and 15 , the weighted mean of the five metals are found to be as shown in table 22. The individual analyses conform fairly well 
for iridium, osmium, and ruthenium, the three major constituents, but for platinum some significant differences appear. The tenors of osmium are consistently greater than those of iridium by values ranging from 2.75 to 9.28 percent, with an average value of 4.46 percent. Hence, this product may be called iridosmine, if use is made of that term. Ruthenium, which commonly occurs with osmium, shows relatively consistent values. The values of platinum, however, range between limits of considerable magnitude, from 4.48 to 18.99 percent. This range suggests that a part of the platinum is alloyed with osmiridium, but that another part may be constained in a minor alloy of platinum that contains considerable iridium but little osmium. Palladium is not shown in these analyses, possibly because its tenor is of the order of mere traces. The ratios of the two postulated alloys could be learned only by determining the composition of one of them.

\section{CAPE OF GOOD HOPE PROVINCE}

Platinum has been found in widely separated areas in the Cape of Good Hope province, but only one of these deposits appears to have any possible significance. The recorded localities are as follows:

1. Dike in altered dolerite, near Cradock.

2. Dike in weathered dolerite and in derived eluvial and alluvial beds near Cala, about 80 miles north of Queenstown.

3. Ocherous shale of the Witteberg series of the Karroo system, near Grahamstown.

4. Small bodies of basic and ultrabasic rocks near Tabankulu, in the district of Griqualand East.

5. A large sill of basic and ultrabasic rocks in Beaufort volcanics of the Karroo system, near Insizwa, district of Griqualand East.

The Insizwa deposit appears to be the most promising of these. According to du Toit (1911) and Wagner (1929, p. 255), this sill has a length of about 12 miles, dipping everywhere toward its center, and thus it simulates a lens-shaped body with a major axis that trends approximately north. This intrusive is mainly gabbro and norite, differentiated to yield at its base a thin sheet of fine-grained perknitic dunite, or picrite. The platinum-bearing minerals occur in the picrite, either in disseminated form, or in veins and tabular masses of massive sulfide ore. The sulfides include pyrrhotite, pentlandite, cubanite, and chalcopyrite, with smaller amounts of bornite, niccolite, and sphalerite. The average tenor of platinum metals, on the basis of exploration so far done, is between 0.025 and 0.05 ounces per ton of ore. The best available information indicates that palladium greatly pre- dominates over platinum. Considerable exploratory work was done on this deposit in 1962, by a large South African mining company.

\section{REPUBLIC OF THE CONGO (KATANGA)}

The province of Katanga, in the east-central part of the Republic of the Congo (formerly the Belgian Congo), and the adjacent part of Zambia (formerly Northern Rhodesia) have large deposits of copper and copper-cobalt ores from which significant amounts of the platinum metals, as well as gold, iron, nickel, lead and zinc are being recovered as byproducts. The total output of platinum metals from electrolytic refineries, in the period 1930-58, according to Quiring (1962, p. 97) was about 52,760 troy ounces, with a maximum output in 1936 of about 15,740 ounces.

- The copper and copper-cobalt mines lie within a parabolic belt with a northern axis and a total length of about 750 miles. The average width of the belt is about 35 miles. Most of the deposits are in Kacanga and adjacent parts of Zambia. Seventeen lodes of copper and 10 lodes of copper-cobalt lie between lat. $10^{\circ}$ and $14^{\circ} \mathrm{S}$., and between long. $24^{\circ} 30^{\prime}$ and $29^{\circ} 30^{\prime}$ E. Four other copper lodes occur farther to the southeast. The production data on platinum metals from these mines, as given by Quiring (1962, p. 97), establish a platinum: palladium ratio of $1: 4$.

\section{RHODESIA}

Platinum was found in 1914 in a cobalt-nickelbearing chromite in the Selukwe district, between Gwelo and Fort Victoria, and in 1918 in a hematitic gossan of dunite near Indiva, about 15 miles east of Gwelo. These and other occurrences of the platinum metals, however, attracted little attention until after the discovery of platinum deposits in the Lydenburg district. Thereafter intensive prospecting was done in Rhodesia on the Great Dike (Great Dyke), an elongate mass of ultrabasic and basic igneous rocks which intrudes the granite that is the principal bedrock of the eastern half of Rhodesia. The Great Dike stretches continuously in a nearly straight line, trending S. $15^{\circ} \mathrm{W}$. for about 320 miles from the headwaters of the Masingua River to the headwaters of the Bubi River. At its northern end, it terminates in a hook-shaped configuration, and beyond its southern end, it continues in intermittent outcrops for an additional 50 miles. The width ranges from 2 to 7 miles, with a mean width of about 4 miles. The layered sheets of this intrusive dip at gentle angles from both sides toward its center. This dike has been called a lopolith, but its structure and genesis have not been definitely proven.

The petrographic succession of rocks, according to Swift (1961, p. 39), consists of a principal basal mass 
composed of layers of pyroxenite and serpentinite. A drill hole at Wedza, bored to a depth of 5,000 feet, showed that the deeper part of this basal mass is entirely dunite, for which reason the surficial serpentinite is attributed to the effects of meteoric rather than magmatic waters. Small xenoliths of granite afford proof of the intrusive origin of the dike. Above the pyroxenite and serpentinite is a layered minor succession of gabbro and norite, with smaller amounts of pyroxenite, which therefore constitute the central part of the synclinal igneous structure.

Two types of platinum-bearing ores have been found in the Great Dike. One consists of stratiform seams of chromite in the serpentinite, ranging in thickness from 4 to 6 inches, with a maximum recorded thickness of 14 inches. From five to 10 such seams crop out in different areas. They appear to be of no economic significance. The principal ores occur in a sheet of pyroxenite which lies 20 to 60 feet below the base of a feldspar-rich norite. These ores have been found at three principal localities. The most important of these lies in the Belingwe district, near the southern end of the intrusive, and includes the well known Wedza mine, about 15 miles west of Shabani. This deposit, which consists of a large volume of oxidized ore in pyroxenite, occurs in a reef 8 to 10 feet thick, of which the uppermost 3 to 4 feet showed tenors in platinum of 0.15 to 0.20 ounce per toll of crude ore. This property was mined in the period 1926-28, and 1,338 tons of concentrates, with platinum tenors ranging from 15 to 258 ounces per ton, were shipped to London. An examination of these concentrates proved the presence of minute octahedra of sperrylite and very small flattened crystals of cooperite, which are believed to be enclosed in iron-copper-nickel sulfides.

A second area is the Makwiro platinum field, about 165 miles north-northeast of the Wedza mine and about 18 miles west-southwest of Norton. The platinum at this locality occurs in a pyroxenitic sheet of the Merensky type, which lies about 30 feet below the feldspar-rich norite. The ore contains iron and copper minerals and is irregularly distributed, with a maximum tenor in platinum metals of 0.15 ounce per ton. A third area is in the Selundi Hills, about 45 miles north-northeast of the Wedza mine and a few miles east of Selukwe.

The Great Dike has been shown by Cousins (1959, p. 186-188) to be merely one of a chain of basic and ultrabasic intrusives that lie approximately along a straight line that trends S. $20^{\circ} \mathrm{W}$. from a short distance south of the Zambesi River, in Rhodesia, nearly to the Orange River, a distance of about 1,000 miles.
This line passes through the Bushveld igneous complex west of Potgietersrust, and it may extend south of the Orange River to some of the occurrences of basic and ultrabasic rocks in the Cape of Good Hope Province. Cousins believes that this line marks the position of a fracture in the crust of the earth that may extend to a great depth.

\section{ETHIOPIA}

Platinum was first produced in Ethiopia by Europeans in 1925, but platinum is known to have been purchased long before that date by itinerant traders, who probably smuggled it through the Sudan into Egypt. From 1927 to 1940 , Ethiopia was a rather important producer of the platinum metals, but in recent years the output has greatly diminished. Quiring (1962, p. 93-94) has estimated that the total output, from 1926 to 1959 was about 90,200 troy ounces, with a maximum production of 8,230 ounces in 1940 .

Platinum was produced in the early years from two general districts, in the valleys of the Didessa and Bir Bir Rivers, and a declining production indicates that no new discoveries have been made and that these remain in the two principal districts. Information is lacking on the Didessa district, but the Bir Bir district was studied by Duparc and Molly (1927), whence come the only geographic and geologic data. The province of Wollega lies west of the province of Shoa, south of the province of Gojjam, and has an area of about 30,000 square miles. Wollega includes some smaller districts, whose names are no longer recognized. The Bir Bir River flows generally south-southwestward to the Baro River, which empties into the Sobat River, which is an eastern tributary of the Bahr el Abiad (White Nile) River; the Didessa River, against which the Bir Bir heads, flows northwestward into the Bahr el Azraq (Blue Nile) River. This platinum field is in a remote area, about 220 miles westsouthwest of Addis Ababa, and is difficult to reach from Addis Ababa, or from the head of navigation on the Baro River.

The productive area in the Bir Bir district is near Yubdo, which is on the west side of the Bir Bir River, on a plateau in which this stream is entrenched. This plateau consists of two well-defined ridges, the Yubdo ridge trending north and the Sodo Ridge trending northwest. The Yubdo ridge lies between the Bir Bir and Kobe Rivers, and its northern extremity is separated from the Sodo Ridge by a western tributary of the Bir Bir River, called the Alfe River. The plateau consists of a basement of ancient crystalline rocks, with may silicic and a smaller number of basic intrusives, mantled by basaltic, trachytic, and other volcanic rocks of Tertiary age. To the east, a sequence of Meso- 
zoic rocks lies between the crystalline rocks and the Tertiary volcanics. The Yubdo and Sodo ridges consist mainly of dunite bordered by pyroxenite, which in turn is bounded discontinuously by gabbroic rocks. At some places where dunite forms the crests of these two ridges, there occurs a well-indurated brownish quartzite, which has been produced by the silicification of dunite. This rock, which contains 9 percent $\mathrm{Fe}_{2} \mathrm{O}_{3}$ and 1 percent $\mathrm{Cr}_{2} \mathrm{O}_{3}$, has been called a birbirite by Duparc and Borloz (1927, p. 137-139). This weathered rock extends below the surface to a depth of 10 to 15 feet, and contains platinum, of which an analysis is later presented. Much of the platinum in this field, however, is recovered from deposits of red clay that mantle the tops and slopes of the hills over an area of about 100 square miles. This represents residual and eluvial material derived from the ultrabasic and basic rocks. Another part of the platinum is recovered from gold-platinum placers in the valleys of the Bir Bir and Didessa Rivers and their tributaries.

Data relating to the character of the platinum are lacking, nor are the accessory minerals of the concentrates recorded. It is reasonably certain, however, that chromite is one of these, as the platinum metals resemble closely those from the Urals. The largest nugget found is said by O'Neill and Gunning (19š4, p. 134) to have come from the Didessa River, or one of its tributaries, and to have weighed 0.48 troy ounce. Two analyses of the platinum metals are available. One, designated below as $\mathbf{A}$, was made by Duparc of a cleaned sample from the birbirite, and this was republished by The Imperial Institute of Great Britain (1936, p. 96). A second analysis, designated as B, was made by Johnson, Matthey and Co., Ltd. These two analyses, and their mean value $(\mathrm{C})$, recomputed to total 100 percent, are as follows:

Analyses, in percent, of platinum metals, Bir Bir district, Ethiopia [N.D., no data]

\begin{tabular}{|c|c|c|c|}
\hline & A & B & $\mathrm{C}$ \\
\hline $\begin{array}{l}\text { Platinum } \\
\text { Iridium } \\
\text { Osmium plus iridium } \\
\text { Ruthenium }{ }_{\text {R }} \\
\text { Rhodium } \\
\text { Palladium }\end{array}$ & $\begin{array}{r}95.82 \\
.99 \\
1.70 \\
\text { N.D. } \\
.90 \\
.59\end{array}$ & $\begin{array}{r}94.60 \\
.84 \\
3.48 \\
\text { N.D } \\
.80 \\
.28\end{array}$ & $\begin{array}{r}95.21 \\
.92 \\
2.59 \\
.85 \\
\text { N.D. } \\
.43\end{array}$ \\
\hline Total & 100.00 & 100.00 & 100.00 \\
\hline
\end{tabular}

\section{SIERRA LEONE}

Platinum was first discovered in Sierra Leone in 1926, and placer mining began in 1929 and continued until 1957, after which no production has been recorded. The total output from 1929 to 1957 is estimated by Quiring (1962, p. 93-94) to have been about 5,560 troy ounces, with a maximum production of about 740 ounces in 1935.

The productive area has been confined to a small peninsular area that extends from Freetown, on the Atlantic coast southeastward for about 25 miles, with a maximum width of 8 or 9 miles. This peninsula is bounded on the northeast by an inlet from the ocean, on the south by Yawri Bay, and on the west by the Atlantic Ocean. The entire peninsula is a rugged and densely forested mountain mass that rises to an altitude of 3,000 feet, and is deeply dissected by numerous mountain streams with high gradients and boulder floors. Mining is impracticable during the wet season, and therefore is carried on from October to June.

The peninsula consists of a large basin-shaped body of basic and ultrabasic rocks, of which the western part, adjacent to the ocean, has been removed by erosion. This is indicated by the fact that the same rocks crop out on Banana Island, which lies offshore to the southwest. These rocks have a well-defined primary banding of stratiform character. The lower part of the intrusive mass is mainly olivine norite or troctolite, whereas the upper part is somewhat less basic. Two large lenticular sheets of coarse-grained anorthosite and anorthositic gabbro have been recognized, and these are believed to be the sources of the platinum metals, as all streams which dissect them have platinum-bearing gravels.

The platinum metals recovered from the placers are coarse grained, and numerous nuggets weighing between 0.25 and 0.52 ounce have been found. One nugget weighed $11 / 4$ ounces. The larger nuggets are invariably waterworn, but small angular grains of crystalline character are also present. A part of the platinum is ferromagnetic. The principal minerals of the concentrates are titaniferous magnetite and ilmenite, and platinum is found adhering to grains of ilmenite. One chemical analysis of the platinum has been published by The Imperial Institute of Great Britain (1936, p. 42). This analysis, recomputed to total 100 percent, is platinum 93.14, iridium 1.01, osmium plus iridium 2.82 , rhodium 1.29 , palladium 1.74 , ruthenium not determined. The absence of osmiridium is indicated.

A geologic exploration has recently been made of this district by a large South African mining company, to determine if possible the bedrock sources of these platinum metals. This work failed in its principal objective, and led to an initerpretation that the platinum metals occur in widely disseminated grains, which over a very long period have been concentrated by weathering and erosion to form the present placers. 


\section{UNION OF SOVIET SOCIALIST REPUBLICS HISTORY AND PRODUCTION}

Platinum was discovered in the stream gravels of the Ural Mountains, according to Sobolewsky (1835), in 1822, and production of the platinum metals began in 1824 and has continued to the present time. At the outset, ruthenium and palladium were not recognized, and even the analyses shown in table 23 do not mention the presence of ruthenium. These placers were slowly depleted, and a search was begun for platinum lodes. Primary ores were found in the Urals in 1890, but proved not to be of the kind that yielded large workable mines. Sometime in the thirties, however, lode deposits of nickel-copper ores containing the platinum metals were found in northwestern Siberia, in the vicinity of Noril'sk. As a result of the development of these and other lodes, and notwithstanding the lessened output from the Uralian placers, the platinum production of Russia has been increasing for some years. Other lodes and some smaller placers have also been found in the U.S.S.R. Among these are the lodes of the Petsamo district, a part of which formerly belonged to Finland.

The production of platinum metals by the U.S.S.R. is approximately known, but it is impossible to separate the placer from the lode outputs. According to the figures presented by Quiring (1962, p. 93-94), the production from 1823 to 1960 has been $12,886,000$ ounces, to which should be added 5,300,000 ounces credited to the U.S.S.R. in the years 1961-65. The total production is therefore about $18,186,000$ ounces up to and including 1965 , which is about $421 / 2$ percent of the world's production. A maximum output of placer platinum, amounting to 241,125 ounces, was made in 1912 . The largest production, coming from both lodes and placers, was 1,700,000 ounces and was obtained in 1965 .

\section{URAL MOUNTAINS \\ LODES}

Primary ores of the platinum metals were found first in the Nishniy-Tagil district, of the Ural Mountains. These consisted of relatively small segregates of chromite, which locally contained accumulations of the platinum metals. These ores have been investigated mainly by Inostranzev (1893), Karpinsky (1926), Duparc and Tikonowitch (1920), Zavaritsky (1928), Vysotsky (1933), and by Betechtin (1930, 1935, 1961). In addition to the publications cited, Betechtin published a series of papers in the Russian language, with no abstract in any other language.

The Ural Mountains lie along the western margin of a belt of basic and ultrabasic rocks, mainly of gabbroic character, which have invaded a country rock consisting of Paleozoic sedimentary rocks and older cry- stalline schists. Figure 4 shows the localities of dunite in the Ural Mountains. The ultrabasic rocks occur in 11 ovaloid dome-shaped masses, with elongations roughly parallel to the axis of the Ural Mountains. These extend over a distance of about 300 miles, between lat $56^{\circ}$ and $60^{\circ} 30^{\prime} \mathrm{N}$., but the more important ones lie within a range of 190 miles. These rocks extend from a point 60 miles N. $30^{\circ}$ W. of Sverdlovsk northward to about 20 miles $\mathrm{N} .15^{\circ} \mathrm{W}$. of Severovral'sk, as shown in figure 4. The ultrabasic masses range in length from 4,000 feet to $61 / 2$ miles and have areas from 300 acres to about 12 square miles.

The principal platinum-bearing rocks are dunite, peridotite other than dunite, and pyroxenite, of which dunite is the most important source rock. The dunite is rarely completely unaltered but shows instead various stages of serpentinization. The unaltered dunite consists almost entirely of olivine in a panidiomorphic fabric, but includes disseminated grains, pockets, stringers, and lenses of chromite. Native platinum is rarely visible in the average dunite, even under the microscope; but where present in ore deposits, it is commonly intergrown with chromite, rarely with olivine. The platinum metals, which include osmiridium, occur generally as minute isolated globules or crystalline grains; but as later described, large segregates of primary platinum have been found. Duparc and Tikonowitch (1920) estimated from the amounts of alluvial platinum metals recovered from the placers that the average tenor of these metals in the dunite of the Nishniy-Tagil area was about 0.13 grain per cubic yard. Obviously, only significant concentrations could be of economic value.

The pyroxenites, which are rather constantly associated with dunite, are classified by Duparc and Tikonowitch as pyroxenite proper and koswite. The pyroxenite consists dominantly of monoclinic pyroxene, but includes also some olivine and accessory magnetite. The koswite (magnetite peridotite) is a more basic rock that contains olivine and magnetite, together with some hornblende. Hornblendite is also present. The gabbros, of which there are numerous varieties, are either barren of platinum metals or have exceedingly low tenors, amounting to mere traces.

The dunites of the Urals were studied in great detail by Duparc and Tikonowitch (1920), and later by Zavaritsky (1928). These writers agree that the ultrabasic rocks of the Urals are segregates from, and not intrusives into, the gabbros. There are, however, a large variety of dike rocks which intrude both the basic and the ultrabasic rocks. The ultrabasic rocks were also affected by still later processes, such as the formation of minerals in miarolitic cavities, later by 


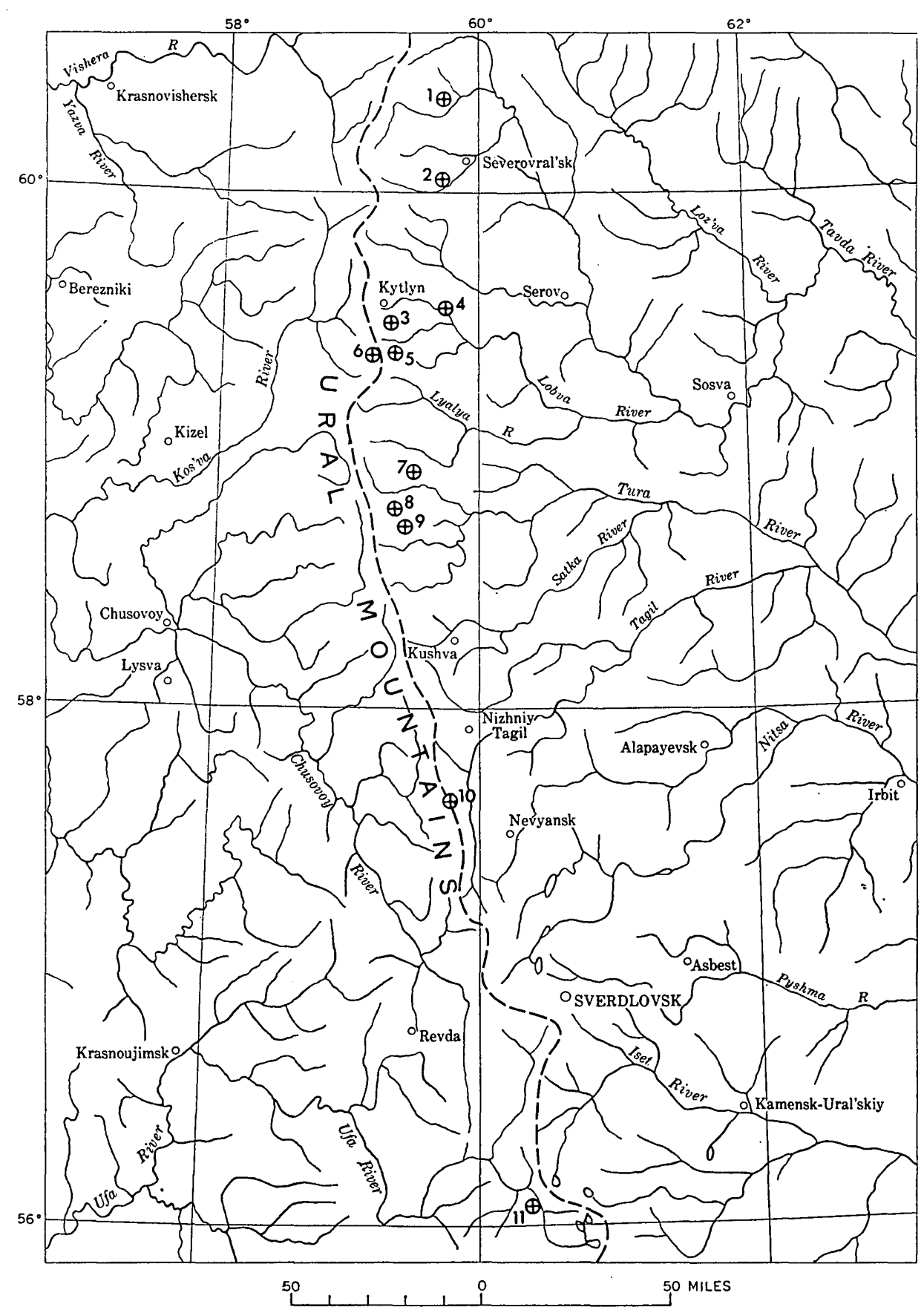

Figure 4.-Dunite localities in the Ural Mountains. 1, Daneskin-Kamen area, drained by the Sosva and Soupreïa Rivers and their headwater affluents. 2, Gladkaïa-Sopka area, drained by the Wagram River and its tributary the Travianka River. 3, Kanjakowsky area, drained by the Severney-Jow and the Pouloudniewaïa Rivers. 4, Garewaĩa area, drained by the Garewaïa and the Jow Rivers. 5, Koswinsky-Kamen area, drained by the Kytlyn River and its headwater tributaries. 6, Sosnowsky-Ouwal area, drained by the Tilaï River and its headwater tributaries, and the Earkovka River. 7, Kamenouchky area, drained by the Niasma River and its headwater tributaries and the Sokolka River. 8, Weressowy-Ouwal area, drained by several headwater tributaries of the Iss River. 9, Swetli-Bor area, drained by the Iss River, and one of its tributaries called the Kossia River, 10, Tagil area, drained on the European side by the Wyssim, Syssim, and Martian Rivers and their affluents and on the Asiatic side by the Bobrowka and Tschauch Rivers and their affluents. 11, Omoutnaĩa area, drained by the Omoutnai River, and a headwater tributary of the Tschoussowaïa River. 
serpentinization, and still later by the formation of carbonates and other minerals of supergene origin.

The dunite of the Nishniy-Tagil district is the largest intrusive of this type in the Urals and may be regarded as typical of the others. This mass, as described by Betechtin (1961) and as illustrated in figure 5 , includes a discontinuous band of antigoriteserpentinite along its western side and is surrounded by pyroxenite (diallageite). The transition from dunite to pyroxenite is characterized by a rock of intermediate character called tilaite, which is composed of diopside, augite, orthopyroxene, olivine, and basic plagioclase feldspar. Eastward from the pyroxenite are successive gabbro, diorite (locally syenite), quartz diorite, and granite. All these rocks pass gradually into one another without sharp boundaries, and suggest complementary species resulting from magmatic or gravitative differentiation.

The dunite of the Nishniy-Tagil district was thought originally to represent a batholith, but it was later proved by Zavaritsky to be a relatively thin laccolith dipping gently eastward. This conclusion was established by gravimetric measurements, which showed that the dunite nowhere extended below a depth of 1.5 kilometers. Later, a drill hole, which was bored to a depth of 600 meters, showed no serpentinization below a depth of 450 meters. This was interpreted to mean that olivine, because it is denser than serpentine, had a superior stability at greater depth. Of possible interest with regard to genesis is the fact that a gas composed of hydrogen, nitrogen, oxygen, and the inert gases was discharged from this borehole for 2 weeks.

The platinum metals of the Nishniy-Tagil district occur within the dunite in irregular masses of chromite, of which about 600 masses have been found. Many of these, however, contain little or no platinum. Generally, chromite occurs as an accessory mineral in the dunite, in amounts ranging from 1 to 2 percent. It is believed by Bethechtin that there existed in the silicate magma an unstable chemical compound of chromium, iron, and platinum, together with fluid components or mineralizers, which were gradually dissipated with falling temperature. The progressive disintegration of this chemical compound produced several other types of chromite deposits, which have different characteristics.

The first and earliest type of ore deposit was formed by direct crystallization from the dunitic silicate magma. During this stage, the chrome ore crystallized in zones and irregular nonlinear aggregates that are characterized by indistinct boundaries and an absence of other accessory minerals. These deposits apparently were entirely of magmatic origin. In a second stage, the chromite accumulated in bodies which, though not entirely regular in outline, were distinct and sharply delineated from the adjacent dunite. These deposits were vein-like and miarolitic, and many of them showed bordering halos that contained chrome-garnet, chromechlorite, and dioside, rarely sulfides. These ores were. found also to be related to crosscutting coarsely crystalline dikes that contained enstatite, diallage, and other minerals of a pegmatitic character. Such ores were therefore considered probably to be both hydrothermal and pegmatitic and were believed to be contemporaneous with an early stage in the decomposition of the postulated chrome-iron-platinum compound.

The third stage in the crystallization of the chromite and platinum metals yielded the more significant ore deposits. This stage apparently marked the final disintegration of the chrome-iron-platinum compound and took place when the dunite was partly congealed and was being subjected to structural dislocations. These conditions resulted in the formation of a brecciated but unaltered dunite with irregular cavities, which were filled with the chrome-iron-platinum compound that still retained a part of its fluid components. These deposits are sharply defined and are considered to be hydrothermal in origin. They are characterized by an abundance of accessory minerals such as chrome-garnet, chrome-diopside, and chrome-chlorite. Most of the chromite-platinum lodes of the Urals are believed to have been formed during this stage of crystallization. They range in length from 1 to 400 feet. Three such lodes, in the Nishniy-Tagil district, are called the Gosshakhta, Aleksandrovskii Log, and the Krutoy Log lodes. In the Krutoy Log property, a mass of high-grade chromite-platinum ore at the top of the ore body extended in one adit for a distance of 2 meters. From this deposit was recovered about 965 ounces of native platinum metals, of which the largest mass weighed $133 / 4$ troy ounces. Unfortunately such deposits were few and widely separated, and none of the numerous chromite ore bodies has been developed into a large producing mine.

A fourth stage in the history of mineralization, contemporaneous with the final solidification of the dunite, resulted in serpentinization, together with the formation of native copper, nickel-iron, magnetite, calcium and magnesium carbonates, brucite, ferrobrucite, and related minerals. This late hypogene process produced only small amounts of platinum and insignificant amounts of iridium. A final stage was marked by exogenic processes whereby supergene solutions, acting upon the olivine, produced iron and magnesium hydroxides and carbonates. 


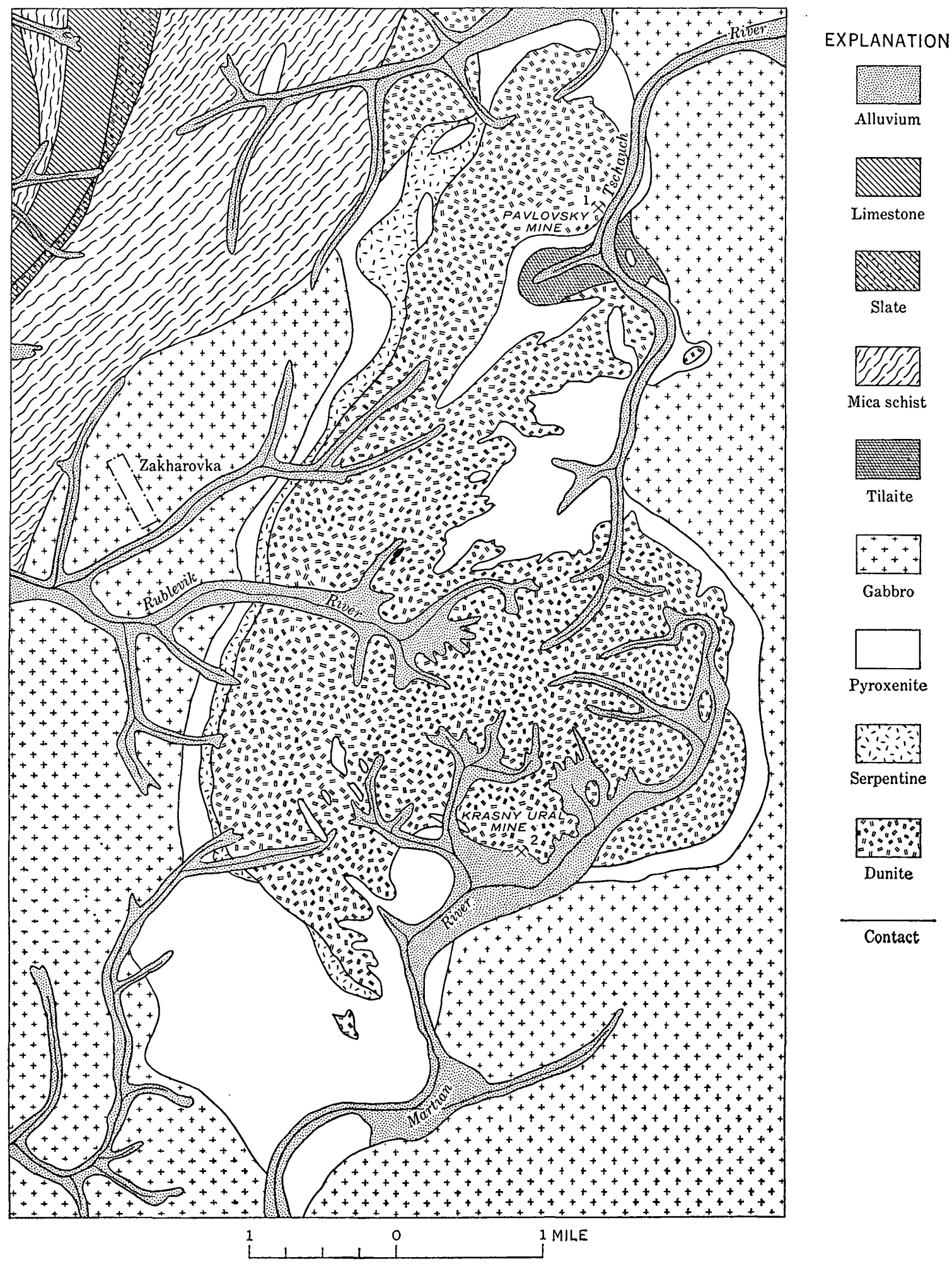

FIgURe 5.-Nishniy-Tagil dunite massif. (From Betechtin, 1961.) 
Zavaritsky $(1928$, p. 37$)$ has presented 15 chemical analyses of primary platinum metals collected from different parts of the Nishniy-Tagil district. These, recomputed to total 100 percent, are shown in table 23. Like all Russian analyses seen by the writer, a part of the iridium is included with osmium, and ruthenium has not been determined. Two mean values have been computed, one including copper, nickel, and iron, and the other without these elements. The ranges in the percentages of copper, nickel, and iron, are respectively 0.50 to $11.41,0.30$ to 3.70 , and 10.76 to 15.55 . It is uncertain whether these three base metals represent dross, or impurities resulting from unseparated heavy minerals, or both.

\begin{tabular}{|c|c|c|c|c|c|c|c|c|c|}
\hline No. & Platinum & Iridium & $\begin{array}{l}\text { Osmium } \\
\text { plus iridium }\end{array}$ & Rhodium & Palladium & Copper & Nickel & Iron & Total \\
\hline $\begin{array}{l}1 \\
2\end{array}$ & $\begin{array}{l}72.43 \\
74.37 \\
78.50 \\
72.49 \\
73.56 \\
74.88 \\
72.01 \\
76.27 \\
74.45 \\
73.66 \\
74.69 \\
55.64 \\
69.84 \\
68.67 \\
72.61\end{array}$ & $\begin{array}{l}7.14 \\
1.54 \\
7.01 \\
1.58 \\
1.83 \\
\text { 1. } 42 \\
\text { 3. } 83 \\
\text { 1. } 57 \\
\text { 4. } 10 \\
\text { 1. } 80 \\
\text { 1. } 08 \\
\text { 4. } 10 \\
\text { 6. } 20 \\
\text { 4. } 74\end{array}$ & $\begin{array}{r}\text { 4. } 22 \\
5.85 \\
8.87 \\
5.75 \\
.52 \\
\text { 4. } 67 \\
\text { 3. } 54 \\
\text { 3. } 62 \\
5.03 \\
2.78 \\
2.42 \\
\text { 14. } 97 \\
9.49 \\
8.21 \\
\text { 4. } 54\end{array}$ & $\begin{array}{r}\text { 16. } 93 \\
.70 \\
\text { N.D. } \\
1.00 \\
.63 \\
.54 \\
.23 \\
.60 \\
1.00 \\
.43 \\
.74 \\
.36 \\
.74 \\
.98 \\
.54\end{array}$ & $\begin{array}{l}\text { N.D. } \\
\text { N.D. } \\
.20 \\
.06 \\
\text { Tr. } \\
.20 \\
.12 \\
\text { Tr. } \\
.18 \\
.05 \\
.15 \\
.11 \\
.10 \\
\text { Tr. }\end{array}$ & $\begin{array}{r}0.87 \\
\text { N.50 } \\
\text { N.D. } \\
2.00 \\
8.62 \\
4.81 \\
8.17 \\
2.94 \\
5.31 \\
5.13 \\
4.06 \\
11.41 \\
3.47 \\
3.49 \\
4.67\end{array}$ & $\begin{array}{r}0.50 \\
\text { N.D. } \\
.30 \\
.95 \\
1.54 \\
.81 \\
1.01 \\
1.05 \\
3.70 \\
1.45 \\
.40 \\
.27 \\
.93\end{array}$ & $\begin{array}{l}\text { 15. } 55 \\
\text { 10. } 76 \\
11.09 \\
11.25 \\
15.03 \\
12.32 \\
12.89 \\
11.81 \\
11.61 \\
12.67 \\
12.54 \\
14.94 \\
11.85 \\
12.08 \\
11.97\end{array}$ & $\begin{array}{l}100.00 \\
100.00 \\
100.00 \\
100.00 \\
100.00 \\
100.00 \\
100.00 \\
100.00 \\
100.00 \\
100.00 \\
100.00 \\
100.00 \\
100.00 \\
100.00 \\
100.00\end{array}$ \\
\hline $\begin{array}{l}\text { Mean } \\
\text { Mean }\end{array}$ & $\begin{array}{l}71.93 \\
87.94\end{array}$ & $\begin{array}{l}\text { 3. } 46 \\
\text { 4. } 22\end{array}$ & $\begin{array}{l}\text { 5. } 62 \\
6.88\end{array}$ & $\begin{array}{l}.65 \\
.80\end{array}$ & $\begin{array}{l}.14 \\
.16\end{array}$ & $\begin{array}{r}4.63 \\
-\end{array}$ & 1. 07 & 12.50 & $\begin{array}{l}100.00 \\
100.00\end{array}$ \\
\hline
\end{tabular}

1 Iridium plus rhodium.

A comparison of the amounts of platinum metals in the Uralian lodes and placers can be made. The means of those that represent the placers of the NishniyTagil district, computed free of impurities, are given in analysis $\mathrm{C}_{2}$ that is shown in table 24 , on page 59 of this report. Comparing the mean values of Zavaritsky's analyses with analysis $\mathrm{C}_{2}$, it will be seen that the tenor of platinum in the former is about 4 percent less than in the latter, that the total iridium plus osmium is about $41 / 3$ percent larger, that rhodium is about 1 percent less, and that palladium is about 0.5 percent smaller, that is, only about a fourth as large. Differences of the same order of magnitude result by comparing the mean of Zavaritsky's analyses with analysis $\mathrm{G}_{2}$, of table 24 , which represents the mean product from all the dunitic areas of the Urals. These differences may be explained in several ways, of which two will be stated. If the principal platinum alloy is intergrown with osmiridium, a possible inference might be that the placer samples represent metals that were eroded from apical horizons in the lodes, whereas Zavaritsky's samples represent metals in different proportions that are characteristic of lower horizons in the lodes. If, on the other hand, the placer samples represent a detrital mixture of two distinct alloys, coming perhaps from different areas in the drainage systems, the discrepancy may be more readily explained by the assumption that the principal platinum alloy was mixed with osmiridium, in approximately a ratio of $20: 1$. The true explanation may be much more complex than the two above cited, and from studies in progress on the platinum metals of the Goodnews Bay district, Alaska, it seems that other interpretations are probable.

\section{PLACERS \\ SOURCES}

The Uralian platinum placers are coextensive with the bodies of ultrabasic rocks of the Urals, as heretofore described. These rocks, and their resulting placers, are divided by Duparc and Tikonowitch (1920, p. 4143 ), into 11 dunitic and five pyroxenitic centers. The dunitic centers and the principal rivers that drain this stretch of the Ural Mountains are shown in figure 4. The headwater tributaries, where most of the placers were mined, cannot be shown on a map of such a small scale, but most of these headwater streams are given in the figure caption. Figure 4 shows that eight of these dunitic centers are on the Asiatic side of the Urals, two are on the European side, and one, the Tagil area, is on both sides. The richest platinum placers of the Urals were in the Tagil area, and here the most important placers were on the European side of the divide. 
Smaller amounts of the platinum metals were also eroded from pyroxenitic bedrock. Each of the dunitic areas is surrounded, or partly bordered by pyroxenite, but in addition to such sources, Duparc and Tikonowitch (1920, p. 49-50) also mention five localities where platinum-bearing pyroxenite occurs without dunite. These are not shown in figure 4 but are located as follows:

1. Tokaïsky area, which comprises a body of pyroxenite whose center lies about 14 miles S. $60^{\circ} \mathrm{E}$. of the Koswinsky-Kamen dunite area.

2. Goussewi-Kamen area, about 10 miles east of the Swetli-Bor dunite area.

3 and 4. Sinaïa-Gora and Kiedrowka areas, about 24 and 15 miles respectively north of the Tagil dunite area.

5. Obleiskaya-Kamenka area, which lies directly west of the Nishniy-Tagil dunite area.

All these areas except the fifth are on the Asiatic side of the Ural Mountains.

\section{PHYSIOGRAPHY}

The physiography and hydrology of the Ural Mountains is briefly described by Duparc and Tikonowitch $(1920$, p. 1-6). The area is one of mature topography, and the rounded mountain tops in that part of the range where the placers occur have altitudes ranging from 1,300 to 3,500 feet. Timberline in the central Urals has a mean altitude of about 2,700 feet, so that much of the area is timbered. The western flanks of the Urals are more abrupt than the eastern flanks, which by Duparc and Tikonowitch is attributed to late tectonic disturbances. This condition is probably reflected in the character of the placer deposits. The streams on both sides of the Urals, and in large measure within the mountains, flow in silt-filled valleys through rolling country, and the water is normally clear, though the more sluggish streams are commonly stained a brownish color by dissolved vegetal matter. Most of the Urals and all the placer-bearing areas lie southwest of the regional belt of permafrost. Wisconsin glaciation, according to Suslov $(1961$, p. 6$)$, extended southward in the Urals to some line between lat $59^{\circ}$ and $60^{\circ}$, and as the placer fields lie between lat $56^{\circ}$ and $60^{\circ} 30^{\prime}$, only the northern fourth of these fields was glaciated in Wisconsin time. Therefore, the placer loci 7 to 11 inclusive, as given above, are in unglaciated territory, and these include the rich placers of the Nishniy-Tagil area. The ice in the glaciated area, however, was rather sluggish, and apparently did not obliterate the placers.
DEPOSITS

The placer deposits have not been adequately described in detail, except perhaps in the Russian language. One early report that contained cross sections of numerous workings was published by Saytzeff (1897, 95 p.). This paper was written in Russian with a short résumé in German. Duparc and Tikonowitch (1920, p. 264-282) have given a classification and general description of the placers. Compiled statements have also been published by O'Neil and Gunning (1934, p. 117121) and by the Imperial Institute of Great Britain (1936, p. 90-93). Duparc and Tikonowitch have classified the Uralian placers into three principal types, to which they have added a fourth and subordinate type. Their classification is as follows:

1. "Lojok" alluvials, which comprise residual and eluvial deposits.

2. Stream placers in the present valley floors.

3. Low terrace deposits of fluvial origin.

4. Certain higher alluvium, to which a Tertiary age. was assigned.

Some generalized sections of these deposits are given. The residual deposits consist of weathered dunitic and pyroxenitic debris, mainly the latter if pyroxenite is present, because dunite disintegrates under weathering more rapidly than pyroxenite. Most of the weathered debris is unsorted, consisting of pyroxenitic fragments in a dunitic sand, but the platinum metals tend to be concentrated toward the base of the section. The rocks are deeply weathered, and the thickness of residual and eluvial deposits may be considerable. The eluvial deposits show some sorting of materials, and grade imperceptibly downstream into the headwater fluvial deposits. Typical stratigraphic sections through the "lojoks," which range in thickness from 18 inches to 70 feet, include an ill-defined basal stratum of platiniferous sand, with a thickness of 6 inches to 10 feet, overlain by sand and rock debris with a thickness of 6 inches to 50 feet. The uppermost part of the deposits consist of turf and vegetal material with a thickness comparable to the basal layer. The thick medial stratum contains a little platinum, but the bedrock, particularly if shattered, may contain considerable alluvial platinum, so that this broken debris has to be removed and cleaned in order to obtain a high recovery. This condition, however, is more prevalent farther downstream, where fluvial action has been marked.

The stream placers range from narrow, shallow paystreaks in the headwater stretches of streams draining areas of ultrabasic rocks to much wider and thicker bodies of alluvium in the lower valleys. Duparc and. 
Tikonowitch give a generalized section, that illustrates apparently the placers in the upper but not the headwater stretches of some of the streams. The section consists of a lower stratum of productive alluvium, ranging in thickness from 10 inches to 5 feet of argillaceous gravel, overlain by 1 to 13 feet of gray-green to yellow porous sands and gravels, in turn overlain by 20 inches to 5 feet of brown to gray clay. The uppermost layer consists of 14 inches to $31 / 3$ feet of turf and vegetal material. The lower stratum is generally workable for its content of platinum metals, but the higher strata are virtually barren.

The placers in the main valleys range in thickness from 10 to 60 feet. In the valley of the Iss River, according to Purington (1899, p. 10), the thickness below the surficial layer of turf and vegetal material ranged from 8 to 24 feet. The turf, which is stripped off before mining, has a thickness of 5 to 20 feet. No sections in the lower valleys are available, but it is known that most of the platinum metals are confined to a relatively thin basal stratum, which is overlain by a thick body of barren or very low grade sand and gravel, commonly interlayered with beds of silt and clay. The surficial stratum consists of turf and vegetal material. The principal bedrock in the main valleys away from the Urals is gabbro, which is deeply weathered to clay, so that the alluvial platinum penetrates into it to a variable depth. This fact makes it necessary for the dredges to dig considerable bedrock. This platiniferous clayey bedrock is difficult to decompose by water, and thus arises a problem in high recovery of the platinum metals. Kemp (1902, p. 75) records the fact that locally there are also beds of productive gravels in the medial overburden. It is probable that the basal platiniferous gravels are buried placers of Pleistocene age, overlain by Recent alluvium, in which the later paystreaks occur.

The widths of these paystreaks, which are narrow in the headwater stretches of the streams, become very wide in the lower valleys. According to a statement by Kemp (1902, p. 70), the workable ground in the lower valleys had widths ranging from 400 to 1,600 feet and in places may have been as great as 2,500 feet. Most of these placers have been repeatedly worked, beginning in the early days with shoveling-in operations in the headwater stretches and culminating in the installation of large electric dredges. Some of the small headwater streams are still worked by hand methods, as are parts of the terrace deposits.

Some of these placers extend a long distance downstream, as for example, in the valley of the Iss River, where the paystreak was worked from the center of the Wéressowy-Ouwal dunite area downstream to the confluence of the Iss and Tura Rivers, a distance by stream of about 50 miles. Thence the paystreak continued down the Tura River for at least 50 more miles. The same conditions apply on the European side of the Nishniy-Tagil area, where the Wyssim, Syssim, and Martian Rivers had paystreaks throughout their lengths and the platinum-bearing gravels continued from their mouths down the Chusovay River, though not in a measure comparable with the deposits on the Tura River. Similarly on the Asiatic side of the Nishniy-Tagil area, the Bobrowka and Tschauch Rivers had long paystreaks.

The terrace deposits on the sides of the main streams evidently lie at no great distances above the valley floors, as it is recorded that they are flooded during periods of extreme high water. Most of the platiniferous sands at the base of the terrace deposits range in thickness from $2 \frac{1}{2}$ to $71 / 2$ feet, and are overlain by clay ranging in thickness from 12 to 33 feet, rarely attaining a thickness of 130 feet. At some localities, two productive strata occur in the terrace deposits, as for example on the Iss River. Type sections of these terrace deposits are as follows:

1. Brown clay (top of section), thickness 12 inches to 33 feet.

2. Productive stratum, in part pebbly, in part argillaceous, thickness 8 inches to 5 feet.

3. Barren brown clay, thickness 22 inches to 28 feet.

4. Productive stratum, generally more clayey than the upper productive stratum, thickness $71 / 2$ inches to $93 / 4$ feet.

5. Sediments of variable character, but unstated thickness. Hence, the depth to bedrock is not known.

It is evident from these sections that the base of the terrace deposits lies far below the level of the valley floor. The widths of the terrace paystreaks range generally from 33 to 165 feet, but some of them attain widths of 500 to 650 feet. The productive sands and clays of these deposits are apparently of Pleistocene age, as they contain numerous remains of Elephas primigenius.

The original tenor of the platiniferous gravels and sands in the rivers draining the Urals is only of historical interest, as all the high-grade ground has been mined and deposits of far lower grade are now being worked. It is recorded that the Wyssim, Syssim, Martian, and Tschauch Rivers, which drain the NishniyTagil area, had at the outset of mining some placers with tenors as high as 10 troy ounces per cubic yard, though this had diminished before the First World War 
to tenors ranging from 0.01 to 0.85 ounce per cubic yard. The same conditions also applied to the placers of the Iss River and its tributaries, that drain the WéressowyOuwal area, though these placers were not as high grade as those of the streams draining the NishniyTagil area. It is not invariably clear whether the quoted tenors refer to the productive strata alone, though it is thought that generally this is true. Purington $(1899$, p. 12$)$ stated clearly, however, that his average value per cubic yard on the Iss River, as of 1899 , referred to the whole alluvial section of $101 / 2$ feet. This overall tenor was about 64 cents per cubic yard, but the platinum metals at this time had only about a third of their present value. The tenors of the ground in the lower valleys, as for example on the Tura River, are not known, but they must be approaching the value of marginal deposits that cease to be workable.

Few data are available on the character and sizes of the noble metals of the stream placers. In the headwater stretches of streams draining the ultrabasic rocks, only the platinum metals occur; but in the downstream stretches, as in the Tura Valley, the ratio of platinum to gold, according to Purington (1899, p. 11), was about $5: 1$. The granularity of the platinum metals, throughout the length, width, and depth of the paystreaks, has not been recorded. Some very large nuggets, however, were found in the headwater stretches of some streams, and these were especially plentiful in the Nishniy-Tagil area. The largest recorded nugget, which was recovered from a tributary of the Martian River, weighed 253/4 troy pounds. Nuggets were less common on the Iss River and its tributaries, but two large ones from the Wéressowy-Ouwal area weighed $221 / 2$ and $101 / 2$ troy pounds. Coarse gold and platinum do not commonly migrate any great distance downstream from their bedrock sources, and it is therefore inferred that the platinum recovered from the lower valley of the Iss River and from the Tura Valley must be exceedingly fine grained-a feature engendering a problem of high recovery. These long paystreaks, however, also suggest either enrichment from local bedrock, or the existence of some geologic process, such as stream rejuvenation, that would distribute the precious metals so far downstream.

\section{CHEMICAL ANALYSES}

Numerous analyses of the platinum metals recovered from the Uralian placers are available, but they are all inferior analyses in which one or more of the components are not determined or are stated in combination with some other platinum metal. The tenors in gold are given, and these must be deleted, as the native gold is free, not alloyed with the platinum metals. Some of these analyses show components designated as sand, manganese, insoluble, and loss, all of which must likewise be deleted. Where tenors in copper, iron, or nickel are stated, however, it seems probable that a major part of these are alloyed elements of the dross, and the analyses are shown both with and without them, recomputed in both analyses to total 100 percent.

Kemp (1902, p. 18-21) published 26 analyses of platinum, seven analyses of osmiridium, and one analysis of platiniridium from the Uralian placers, most of which came from the Nishniy-Tagil area. The analyses of osmiridium, which are known to have come from the vicinity of Syssertsk, were later republished by Duparc and Tikonowitch (1920, p. 189). The analyses of platiniridium, made in 1835 , is omitted in computing a mean analysis, as no similar platinum alloy has been recorded from this area. The 26 samples of platinum are said by Kemp to have been nuggets, but it is not clear whether each sample was a single nugget, or an assemblage of small nuggets.

Duparc and Tikonowitch (1920, p. 237-249) published 86 analyses of platinum metals from the Uralian placers, of which 79 came from the valleys of streams that drain areas of dunite and seven from valleys that head in pyroxenite. The two principal dunitic areas are one near Nishniy-Tagil, and a second area that includes the Wéressowy-Ouwal and Swetli-Bor centers. In so far as placer platinum is concerned, it would be difficult to separate the two last-named centers, as the boundaries of their dunite masses are separated by only a mile and both are drained by tributaries of the Iss River. Platinum analyses from four of the five pyroxenitic areas are separately tabulated by Duparc and Tikonowitch (1920, p. 247). It would be desirable to present mean analyses of the platinum metals from all 16 areas, as it appears that many of these yielded platinum metals with distinct characteristics. But most of the areas have too few analyses to yield dependable mean values. Thirty-seven analyses, however, are available from the Nishniy-Tagil area, and 26 from the Wéressowy-Ouwal and Swetli-Bor areas, which are the two most productive centers. These analyses, as shown in table 24, are assembled in the seven sets.

The analyses $\mathrm{A}_{2}, \mathrm{C}_{2}, \mathrm{D}_{2}$, and $\mathrm{E}_{2}$ are surprisingly uniform in their tenors of the platinum metals and dross, departing little from the proportions shown in $\mathrm{G}_{2}$, which is a weighted mean analysis of 168 samples from dunitic areas. The only other comparably large group of analyses, as shown on page 88 of this report, represent the metals derived from dunite at the placer mine near Platinum, Alaska. It is noticeable that the Uralian analyses show more platinum, but 
$\mathrm{T}_{\mathrm{ABLE}}$ 24.-Mean analyses, in percent, of placer platinum metals, Ural Mountains

[N.D., no data; Tr., trace]

\begin{tabular}{|c|c|c|c|c|c|c|c|c|c|}
\hline Samples & Platinum & Iridium & $\begin{array}{c}\text { Osmium plus } \\
\text { iridium }\end{array}$ & Ruthenium & Rhodium & Palladium & Copper & Iron & Total \\
\hline $\begin{array}{l}\mathrm{A}_{1} \\
\mathrm{~A}_{2} \\
\mathrm{~B}_{1} \\
\mathrm{~B}_{2} \\
\mathrm{C}_{12} \\
\mathrm{C}_{2} \\
\mathrm{D}_{12} \\
\mathrm{D}_{1} \\
\mathrm{E}_{1} \\
\mathrm{E}_{2} \\
\mathrm{~F}_{1} \\
\mathrm{~F}_{2} \\
\mathrm{G}_{1}\end{array}$ & $\begin{aligned} 77.99 \\
91.32 \\
2.47 \\
2.50 \\
77.96 \\
92.02 \\
83.58 \\
92.94 \\
79.79 \\
91.46 \\
85.66 \\
95.57 \\
79.69 \\
91.79\end{aligned}$ & $\begin{aligned} 2.04 \\
2.39 \\
56.07 \\
56.72 \\
2.49 \\
2.94 \\
1.31 \\
1.46 \\
2.26 \\
2.59 \\
1.00 \\
1.12 \\
2.13 \\
2.46\end{aligned}$ & $\begin{array}{r}2.45 \\
2.87 \\
33.47 \\
33.86 \\
2.16 \\
2.55 \\
3.88 \\
4.32 \\
3.60 \\
4.13 \\
.74 \\
.83 \\
3.15 \\
3.62\end{array}$ & $\begin{array}{l}\text { N.D. } \\
\text { N.D. } \\
4.36 \\
4.41 \\
\text { N.D. } \\
\text { N.D. } \\
\text { N.D. } \\
\text { N.D. } \\
\text { N.D. } \\
\text { N.D. } \\
\text { N.D. } \\
\text { N.D. } \\
\text { N.D. } \\
\text { N.D. }\end{array}$ & $\begin{array}{l}\text { 2. } 40 \\
\text { 2. } 81 \\
2.48 \\
2.51 \\
\text { 1. } 54 \\
\text { 1. } 82 \\
.70 \\
.78 \\
\text { 1. } 11 \\
\text { 1. } 27 \\
\text { 1. } 18 \\
\text { 1. } 31 \\
\text { 1. } 34 \\
\text { 1. } 55\end{array}$ & $\begin{array}{r}0.52 \\
.61 \\
\text { Tr. } \\
\text { Tr. } \\
.57 \\
.67 \\
.45 \\
.50 \\
.48 \\
.55 \\
1.05 \\
1.17 \\
.50 \\
.58\end{array}$ & $\begin{array}{r}1.38 \\
.33 \\
2.04 \\
.68 \\
1.44 \\
72 \\
1.45\end{array}$ & $\begin{array}{r}13.22 \\
.82 \\
13.24 \\
9.40 \\
11.32 \\
9.65 \\
11.74\end{array}$ & $\begin{array}{l}100.00 \\
100.00 \\
100.00 \\
100.00 \\
100.00 \\
100.00 \\
100.00 \\
100.00 \\
100.00 \\
100.00 \\
100.00 \\
100.00 \\
100.00 \\
100.00\end{array}$ \\
\hline
\end{tabular}

Localities of cited analyses

$A_{1}$ and $A_{2}$ Moan of 26 analyses of platinum metals (Kemp, 1902), with and without $B_{1}$ and $B_{2}$ Mean of seven analyses of osmiridium (Kemp, 1902), with and without

$C_{1}$ and $C_{2}$ Mean of 37 analyses of platinum metals from the Nishniy-Tagil area $\mathrm{D}_{1}$ and $\mathrm{D}_{2}$ (Dean of 26 and Tiksonowitch, 1920), with and without the base metals. Swean of 26 analyses of platinum metals from the Weressowy-Ouwal and
Sworeas (Duparc and Tikonowitch, 1920), with and without the base metals.

only half as much iridium plus osmium, as do the Alaskan analyses. On the other hand, the Uralian analyses show more rhodium and palladium than do the Alaskan analyses.

Samples $F_{1}$ and $F_{2}$, from one of the Uralian pyroxenic areas, probably represent a principal alloy of platinum containing little or no osmiridium. This is indicated by a tenor in platinum higher than those of $G_{1}$ and $\mathrm{G}_{2}$, by the lower tenor in iridium plus rhodium, and by a distinctly higher tenor in palladium. On the other hand, analyses $\mathrm{B}_{1}$ and $\mathrm{B}_{2}$, as presented by Kemp, represent seven samples from the vicinity of Syssertsk, which are quite different. These show very low tenors in platinum, with nearly 90 percent iridium plus osmium and practically no palladium. Obviously such analyses represent osmiridium, with no intergrown platinum alloy of the ordinary type, though one of these seven samples contains nearly 10 percent platinum, which is sufficient to suggest a minor intergrowth of the ordinary platinum alloy.

Areal mean analyses, however, from areas of dunitic and pyroxenic bedrock do not give a complete picture of the variable character of the platinum alloys. One example of a marked variation from the cited analyses is the mean analysis of a number of placer samples from the Kanjakowsky dunite area, which shows 62.50 percent platinum and about 24.30 percent "osmiure," or combined iridium and osmium. Obviously such platinum metals represent two alloys, of which osmiridium constitutes an important, though not the major $329-505-69-5$
$E_{1}$ and $E_{2} \quad$ Mean of 79 analyses of platinum metals from dunitic areas of the Urals $F_{1}$ and $F_{2}$ (Duparc and Tikonowitch, 1920), with and without the base metals. of the Urals (Duparc and Tikonowitch, 1920), with and without the $G_{1}$ and $G_{2}$ base metals.

eighted mean of 168 analyses of platinum metals represented by $\mathbf{A}_{\mathbf{1}}$, $A_{2}, C_{1}, C_{2}, D_{1}, D_{2}, E_{1}$, and $E_{2}$, with and without the base metals.

component. Still greater variations in the proportions and compositions of the component alloys are apparent in individual analyses.

The ratios between the different platinum metals have considerable interest and significance, not merely for interpreting the analyses of any one product, but also for comparing products from different regions. For the Uralian product, and in fact for most of the platinum metals elsewhere recovered, the establishment of certain useful ratios is not feasible, first because the contained iridium and osmium are usually not completely separated, and second because the content of ruthenium is rarely determined. Osmium and ruthenium occur mainly in osmiridium, and their ratio is generally nearly constant, so that the sum of these two elements may function as a fixed numerator or denominator in formulating distinctive ratios. Because platinum, iridium, and rhodium occur both in the principal alloy and in osmiridium, the ratios $\mathrm{Pt}: \mathrm{Os}+\mathrm{Ru}, \mathrm{Ir}: \mathrm{Os}+\mathrm{Ru}$, and $R h: O s+R u$ are particularly significant and useful when they can be obtained. For the Uralian placers, however, all that may be safely stated is that the ratio $\mathrm{Pt}: \mathrm{Ir}+\mathrm{Os}+\mathrm{Ru}$ is approximately $15: 1$, whereas for the Alaskan product the corresponding value is $6: 1$. The higher ratio indicates a large predominance of the principal alloy over osmiridium, and it is estimated that the ratio of these two alloys for the Uralian product is between 20:1 and 25:1, whereas the same ratio for the Alaskan product is believed to be about $12: 1$. This ratio, though doubtless variable in bedrock, tends to approach a constant mean value in the 
placers and serves to characterize the placer platinum products in different parts of the world. The most distinctive feature of the placer platinum metals found in the Urals, Alaska, and elsewhere in the world is their low content of palladium, as compared with the platinum metals recovered from the lodes of Canada, Siberia, South Africa, and all other platinum-bearing lodes.

Other differences exist in the Uralian platinum samples with regard to their included base metals, if these are interpreted as dross. The mean of the analyses of samples from the Nishniy-Tagil area $\left(\mathrm{C}_{2}\right)$ and the mean of Kemp's analyses $\left(A_{2}\right)$, thought likewise to have come from the same area, are nearly 5 percent higher in base metals than the corresponding mean analysis of samples from the Wéressowy-Ouwal area, yet both these mean analyses represent samples from areas of dunite. On the other hand, the mean analysis of samples from areas of pyroxenite shows about the same amount of base metals as the mean analysis of samples from the Wéresowy-Ouwal area. These facts suggest that none of these four means represent dross alone, but instead that all of them include undetermined amounts of extraneous impurities. It also is noteworthy that osmiridium, where it exists as a distinct alloy, constituting all the placer product, has a very low content of dross.

Few data are available regarding the heavy minerals that constitute the concentrates recovered with the platinum metals, but it is recorded that numerous such minerals have been identified. The only heavy minerals noted by the writer in the published descriptions are magnetite and chromite, though doubtless ilmenite is also present. At some places cinnabar is specifically mentioned, but this is obviously. derived, not from dunite or pyroxenite, but from veins in gold-bearing granitic rocks within the basins of the Uralian streams.

\section{NORIL'SK DISTRICT}

The geographic position of Noril'sk, the general geology of the Noril'sk district, and the drainage of the surrounding country are shown in figure 6. Mount Rudnaya, also known as Rudnaya Gora (ore mountain), is the site of the original discovery of the platinum-bearing copper-nickel ores that are now being exploited. Its reported geographic position is approximately lat $69^{\circ} 20^{\prime} \mathrm{N}$., long $88^{\circ} 8^{\prime} \mathrm{E}$. A number of other similar deposits are also known in this area, of which some are being mined. Among them are the Sotnikovskol deposit, which is adjacent to Rudnaya Gora; the deposit at Mount Barjernaja, east of Rudnaya Gora; the Ugal'nyi Ruckey deposit, about 1.6 miles south of Rudnaya Gora; the Noril'sk II deposit, located approximately at lat $69^{\circ} 00^{\prime} \mathrm{N}$., long $89^{\circ} 00^{\prime}$ E., and the occurrence on the Rybnaja River, about 6.2 miles southeast of Rudnaya Gora. Geologic environments similar to those near Noril'sk exist also about 250 miles to the east, and continue southward from Noril'sk for 400 miles or more, so that the prospect of new discoveries are excellent. Production of platinum metals from the Noril'sk district began in 1940, and by 1947 constituted 30 percent of the annual production. This percentage has continued to increase in recent years.

The geologic environment of the ore bodies in the Noril'sk district resembles in some respects that at Sudbury, but differs markedly in others. Northwest and south of Noril'sk are numerous sedimentary formations, mainly of Paleozoic age, and southwest of Noril'sk is a large elliptic area of Triassic lavas of about 2,000 square miles. The Paleozoic rocks, from Cambrian to Carboniferous, include many limestones, but one Permian formation consists of sandstone and slate, with some beds of coal. Owing to the large area shown in figure 6, the Paleozoic sedimentary formations are not separately delineated. Numerous basic intrusives invade both the Paleozoic and the Triassic rocks, and these, though assigned an age of Carboniferous to Lower Mesozoic on Spizharskiy's (1959) geologic map, must be in part Triassic or post-Triassic in age. They are probably related genetically to the Triassic trap-rocks. The ore bodies are localized at the contacts of the intrusives with certain of the Paleozoic rocks. Shimkin $(1953$, p. 79) mentions as the principal loci of the ore deposits the contacts between the intrusives and Silurian limestones or Permian and Carboniferous "sands and clays." Genkin (1959) however, emphasizes the fact that the ores at Rudnaya Gora and at certain other localities are localized at the contacts of the intrusives with the coal-bearing Tungusk (Permian) coal-bearing formation.

The intrusives are mainly diabase (dolerite by transliteration from the Russian) and gabbro-diabase but include differentiated rocks such as picrite, tschenite, labradorite prophyrite, titaniferous augite diabase, and other specialized types. These intrusives differ morphologically from those at Sudbury in that they occur as large dikes, sills, and less regular intrusive bodies. The essential minerals of the undifferentiated rocks are plagioclase feldspar (commonly labradorite), augite, hornblende, biotite, and olivine, with the secondary minerals chlorite, serpentine, sericite, prehnite, and the zeolites.

The ore deposits at Rudnaya Gora are of two principal types. The high-grade ores occur as veins and lenses; the low-grade ores occur as disseminated deposits 


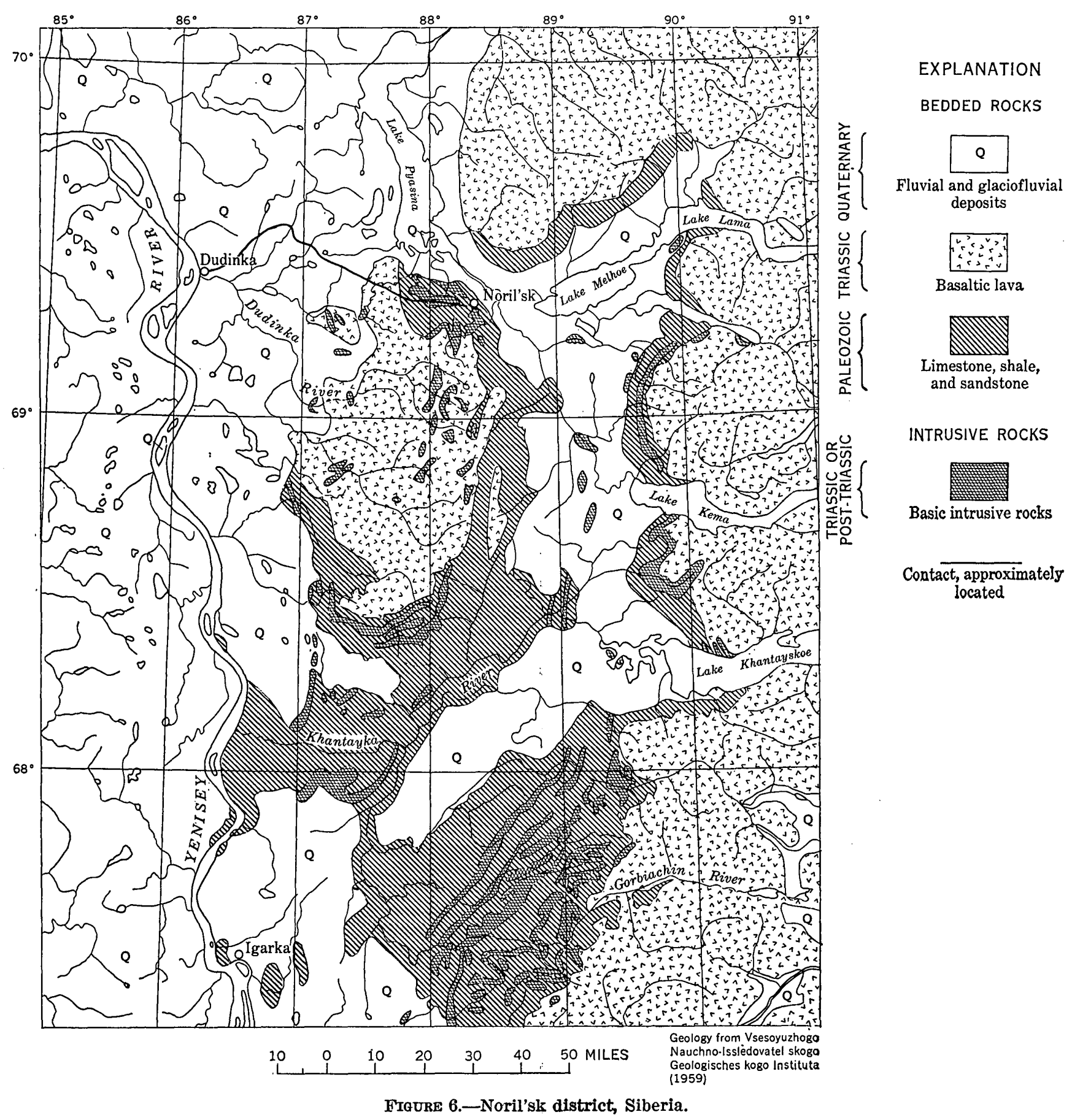

in the basic intrusives. The country rock at Rudnaya Gora is sandstone and shale, which are intruded by gabbro along a fault plane striking north-northeast. One ore body, which lies in a lenticular zone in the gabbro adjacent to its footwall, has a length of about 345 feet, a width of about 200 feet, and a thickness of about 70 feet. Another ore body of lower grade consists of disseminated sulfides in the gabbro along its hanging wall and footwall.
The ore minerals of both types, according to Genkin (1959), are pyrrhotite, chalcopyrite, pentlandite, cubanite, and pyrite, with which are associated small amounts of violarite, valleriite, sphalerite, galena, polydymite, sperrylite, and other minerals and alloys of the platinum metals. In the occurrence of native alloys of palladium and platinum, these deposits differ from those at Sudbury, and are more closely related to the ores of the Transvaal. They differ, however, from the 
Merensky zone in that the ores and host rocks of the latter are magmatic differentiates.

Various values have been published regarding the tenors in copper, nickel, cobalt, and platinum metals in the Noril'sk district. Quiring (1962, p.195) gives mean values for an ore lens at Rudnaya Gora of 2.16 percent copper, 1.23 percent nickel, 0.1 percent cobalt, and 0.34 ounce platinum metals per ton of ore. The tenors of the adjacent disseminated ores are given as 0.11 to 0.31 percent copper, 0.11 to 0.31 percent nickel, and 0.002 to 0.13 ounce platinum metals to the ton. For the Noril'sk area, however, Shimkin $(1953$, p. 147) quotes mean tenors of 0.47 percent copper, 0.31 percent nickel, 0.1 percent cobalt, and 0.07 ounce platinum metals per ton, which are about a fourth as large as those first cited. It is possible that Shimkin's figures relate to the vein deposits plus some unspecified part of the disseminated deposits that is mined. Quiring also quotes mean tenors at the Ugal'nyi Ruckey deposit as 0.65 percent copper, 0.45 percent nickel, 0.06 percent cobalt, and 0.17 ounce platinum per ton. As the ore at Ugal'nyi Ruckey is known to be of lower grade than that at Rudnaya Gora, the stated interpretation of Shimkin's values seems reasonable.

A large but undetermined part of the platinum metals at Rudnaya Gora occurs in four minerals, of which three are palladium minerals. A smaller part of the platinum metals occurs in four alloys, whose compositions have been determined by Genkin and his co-workers. These are solid solutions with variable proportions of palladium, platinum, iridium, iron, nickel, copper, tin, and silver. They are not true minerals, and many additional compositions could doubtless be discovered. The overall platinum:palladium ratio for the Noril'sk deposits is given by Genkin (1959) as 1:10. On the other hand, the platinum :palladium :iridium ratio for an ore lens at Rudnaya Gora is given by Quiring $(1962, \mathrm{p}$. 195) as $3: 6: 1$. These disparate values indicate at least that palladium is from 2 to 10 times as plentiful as platinum and therein these deposits differ from both those at Sudbury and those of the Merensky reef in the Transvaal.

The platinum minerals and alloys are rarely identified in the disseminated copper-nickel sulfides, and in this environment are believed to exist either as minute crystals, or finely divided precipitates in the sulfides, or as solid solutions replacing certain cations in those minerals. In the vein deposits, the platinum minerals exist as discrete crystalline grains in masses of sulfides or as recognizable veinlets and aro believed to have been formed after the crystallization of the sulfides that surround them. This genesis is corrobo- rated by the presence of minute inclusions of chalcopyrite, cubanite, pyrrhotite, and pentlandite within the platinum minerals. Bornite, which is not an ore mineral, has been identified as an inclusion in the platinum minerals. The ore veins generally contain seven or eight platinum minerals and alloys of very diverse composition, which exist as close intergrowths with one another, or as minute inclusions. In paragenetic association with the platinum minerals are small amounts of native gold and gold-bearing minerals.

Little has been published regarding the outlying ore deposits of the Noril'sk district. The deposit at Sotnikovskol consists of concentrations of secondary ore minerals along the bedding planes of coaly shale interbedded with marl. The ore tenors are given by Quiring (1962, p. 195) as 0.09 percent copper, 0.07 percent nickel, and 0.012 ounce platinum metals per ton of ore. The ore at Ugal'nyi Ruckey is a zone of disseminated sulfides about 95 feet thick, adjacent to the hanging wall of a sheet of diabase flanked above by a diabasic intrusive. Veinlets of ore also cut the intrusive body along its footwall. The mean tenor of the ores has earlier been stated. The ore body at Noril'sk II consists of an intrusive mass of gabbro and diabase that contains disseminated sulfides.

\section{PETSAMO DISTRICT}

The region of Pechenga-Monchegorsk, commonly called the Petsamo district, is a part of the Kola Peninsula that formerly belonged to Finland. Two well-known nickel-copper deposits, known as the Petsamo and Monchegorsk lodes, are in the district. A mass of basic intrusives of Precambrian age within this area is being intensively developed by Russia as sources of nickel, copper, and probably of platinum metals. A comprehensive report on these deposits, including their geology, structure, mineralogy, and ores, and the geochemistry of nickel, was published recently by Eliseev, Gorbunov, Eliseev, Maslenikov, and Utkin $(1961,350$ p.), but this report is written in Russian with no summary in any other language. The Petsamo lode is larger and richer in copper and nickel than the Monchegorsk lode, yet no mention is made of platinum metals at either property, though they are reported to be present. The principal sulfide is pentlandite, with less chalcopyrite, and a minor amount of cobaltite. According to Shimkin (1953, p. 78), the nickel :copper ratio is about $2.3: 1$ and the nickel :cobalt ratio about 58:1. The tenor in nickel at the Petsamo lode is between 3.5 and 4.0 percent, and the Monchegorsk lode about 1.8 percent. The tenor in platinum metals has not been published. 


\section{MINOR DEPOSITS}

Platinum has been found in bedrock and in platinum-bearing gold placers at many other Russian localities, mainly in Siberia. Such occurrences indicate a widespread distribution of platinum in bedrock, but excepting the deposits of the Noril'sk and Petsamo districts, these deposits have not been developed into workable lodes. Numerous localities are enumerated and briefly described by Quiring (1962, p. 188-199).

One of the areas mentioned by Quiring (p. 199) is the basin of Vilni River, in east-central Siberia, where platinum has been found both in bedrock and in gold placers. Seven analyses are given of the placer platinum which if recomputed to total 100 percent, with and without the base metals, yield the mean values shown in table 25. It is clear that these seven analyses represent mixtures of ordinary platinum and osmiridium.

$\mathrm{T}_{\mathrm{ABLE}}$ 25.-Analyses, in percent, of placer platinum from Vilni Basin, Siberia

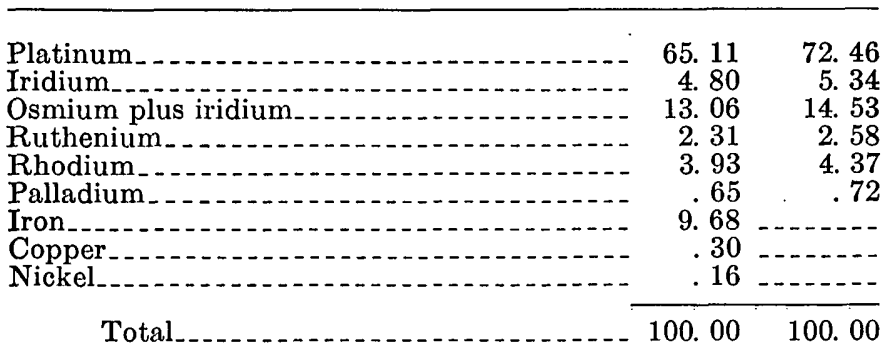

Another area of some interest mentioned by Quiring (p. 192-193) is in the valleys of Timpton and Zeya Rivers, Amur Province, southeastern Siberia, where platinum-bearing gold placers occur. Quiring presents four analyses, of which two represent crude platinum, one represents ferroplatinum, and one represents a nonmagnetic iridium-rich alloy. The means of these four analyses, with and without the base metals, recomputed to total 100 percent are shown in table 26. This mean analysis indicates the presence of considerable osmiridium in these placers. It is also of interest that the concentrates recovered with these platinum metals

TABLE 26.-Analyses, in percent, of placer platinum of Timpton Valley

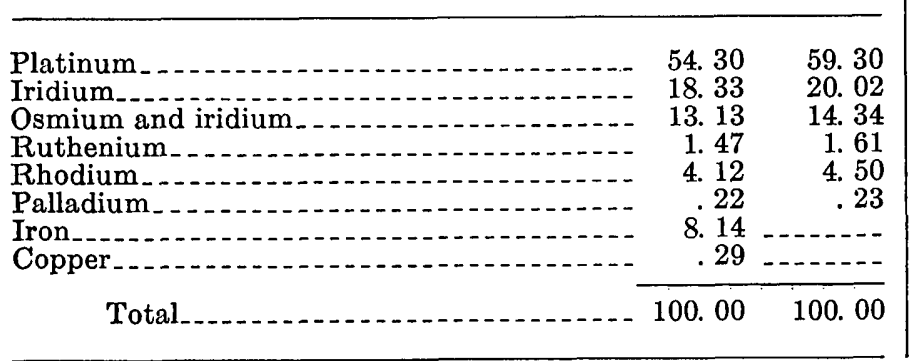

consisted of sperrylite, magnetite, ilmenite, garnet, and zircon. An analysis of this sperrylite is given in table 8 , analysis $\mathrm{C}$.

Other localities where the platinum metals have been found in bedrock, mainly in Asiatic Russia, are given in a list presented under the description of the placers. Most of these are predominantly gold placers, but obviously platinum-bearing bedrock must be present at these localities, though no descriptions of the lodes are available.

\section{COLOMBIA HISTORY AND PRODUCTION}

The discovery of platinum in Colombia has already been described, and the early years of mining, starting in 1778, have also been mentioned. The history of placer mining subsequent to 1778 is not known, but for a hundred years much work was done by primitive methods. In the latter part of the 19th century, however, companies entered the field to work these deposits on a larger scale. One of the earlier attempts at large scale mining was made in 1882 , in the province of Antioquia, on the Nechí River, a tributary of the Cauca River, which flows via the Brazo de Loba River to the Magdalena River. Platinum-bearing gold placers were also found in 1917 on the Caseri River, a tributary of the Nechí River.

Dredging began on the Nechí River sometime before 1900 , and there remains today the wreck of an old French dredge that was operating as early as 1903. One of the dredges now operating on the Nechí River has been in continuous service since 1910. Several companies originally operated dredges on the Nechí River, but these were gradually taken over by a Canadian company, called Pato Consolidated Gold Dredging, Ltd., which is one of the largest placer mining concerns in the world. As of 1964, 67 percent of the stock of this company is owned by the International Mining Corp. Seven Pato dredges are now operating on the Nechí River downstream from Zaragoza. All this work, however, is mainly gold placer mining, as the annual output of platinum from these dredges does not exceed 15 ounces. This is significant merely because it shows a continuity in the occurrenco of platinum over many miles of territory.

Platinum metals occur at many localities along and close to the Pacific Coast, from Panama to Ecuador. The most important of these deposits is on the Telembi River, a tributary of the Patía River, about 40 miles northeast of the Colombia-Ecuador boundary lines, in the province of Nariño. Gold and platinum have been found in the valley of the Baudó River in the western 
part of the province of Choco, but no deposits of economic value appear to have been located. Gold and platinum also occur along the Pacific beaches from Buenaventura southwestward at least as far as Ecuador; and in the provinces of Valle del Cauca and Cauca, placers have been found and worked on a small scale on a number of streams that flow directly to the Pacific Ocean. The principal of these, named from north to south, are the Raposa, Yurmanangul, Micay, Timbiqui and Guapi Rivers, but these placers have yielded only small amounts of the platinum metals. Still farther south, platinum-bearing gold deposits have been reported in the valleys of the Boyota, Cachabi, Uimbi, and Cayapas Rivers, all tributaries of the Santiago River, in northwestern Ecuador. From the foregoing enumerations, together with the subsequent description of the placers of the Choco district, it is evident that a platinum province extends from Panama almost to Chile, a distance of about 800 miles.

The placers of the Chocó province are the principal sources of platinum in South America. Modern exploration and mining of these deposits were begun in 1887, in the vicinity of Quibdo and have continued to the present time. The first dredge was built by a British company on the Condoto River in 1915, and the second a short time later on the Opogodó River. In 1918, however, a dredge was built by the American Gold and Platinum Co., and this was followed by five other dredges of which the last was built in 1938. Dredging in the interval 1918-66 was done mainly by this company and by its subsidiary, the Compañia Minera del Chocó Pacífico, but in 1963 these companies were merged with the International Mining Corp. The writer is greatly indebted to Mr. Patrick H. O'Neill, executive vice-president of the International Mining Corp. and chairman of the board of Pato Consolidated Gold Dredging, Ltd., for most of the up-to-date information on dredging operations in Colombia published in this paper.

Four dredges were operated by the International Mining Corp. in the Chocó district in 1963-64. One dredge operated near Chiqui Choqui on the San Juan River, at the western side of the Big Flat; another was located in the valley of the Opogodó River, in the central part of the Big Flat; and a third worked the stream placers near Tambito, at the upper end of the paystreak on the Tamaná River; and a fourth operated on another large flat within the basin of the Novita River and the Quebrada Carmen. All four of these dredges produce both gold and platinum metals, with platinum-gold ratios ranging from $3: 1$ to $1: 22$.
Mining by primitive methods also continues in the Chocó district, mainly in the valleys of San Juan and Atrato Rivers and their tributaries. According to Mr. O'Neill, between 20,000 and 25,000 natives are engaged in this work, and their total production is estimated to exceed by 30 percent that of the dredges. Most of this platinum is purchashed by speculative buyers, by whom it is smuggled into Panama. Hence the official output of platinum metals cited for Colombia is really less than half the true production.

Most of the natives recover the precious metals by hand panning, using a scooplike instrument to scrape the gravel into a wooden batea. Much of this mining is done along the margins of the valley floors and terraces, but the upstream ends of the river bars and the bottoms of the rivers (at low stages of water) are also worked. At some sites, the sand and gravel from the valley walls and terraces are washed by ditchwater in rocklined sluices, which are cleaned up daily or weekly. Bar and bottom mining are done entirely with bateas. The natives are not allowed to work closer than 100 meters to an operating dredge.

The production of platinum metals from Colombia, from 1778 to 1960 according to Quiring (1962, p. 9394 ), was $3,357,500$ troy ounces, to which should be added the production of 1961-65. Thus, the total recorded production from 1778-1965, inclusive, is approximately $3,446,500$ ounces. The maximum production was in 1928 , when the output was 61,985 ounces.

\section{INTENDENCIA DEL CHOCÓ GEOGRAPHY}

The gold-platinum placers of the Choco lie along the west flanks of the Cordillera Occidental, mainly in the valleys of the San Juan and Atrato Rivers. The San Juan River, which is the principal site of the platinum metals, flows southward, and then veers westward in southern Chocó to flow to the Pacific Ocean. The Atrato River flows northward through Colombia, and then veers westward into Panama, where it empties into the Caribbean Sea. The drainage patterns of the San Juan and Atrato Rivers within the piedmont province, together with the principal streams which lie between these two rivers and the Pacific Ocean, are shown in figure 7.

The Cordillera Occidental is a range of rugged mountains which rises to altitudes of 7,000 to 13,000 feet. Along its western flanks this range is drained by many streams with high gradients that have cut deep precipitous gorges. Among such streams are the eastern headwaters of the San Juan and Atrato Rivers. Between the Cordillera Occidental and the Pacific 


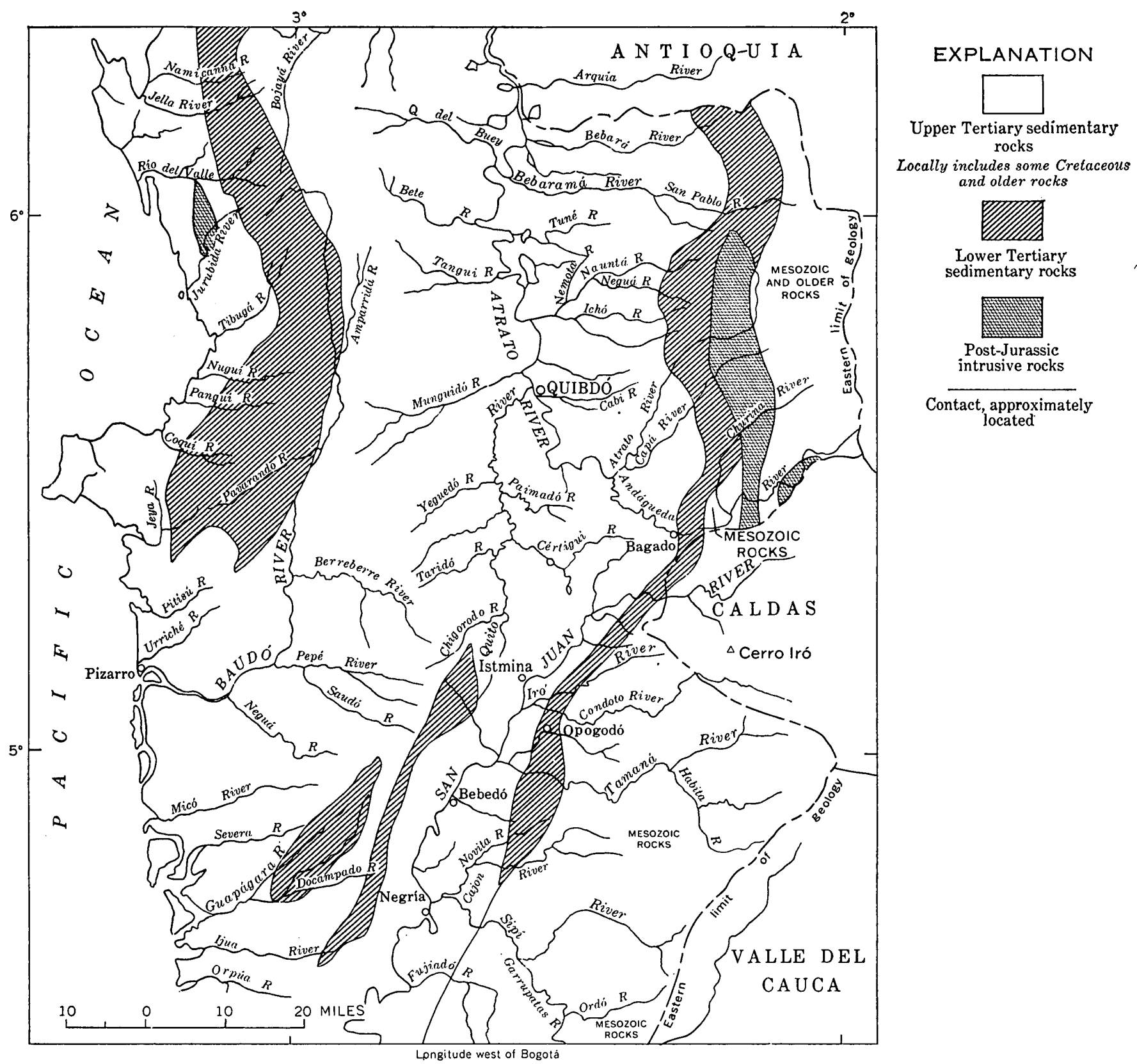

FrauRe 7.-Chocó platinum district, Colombia. (Modified from Colombia Servicio Geológico Nacional, 1946.)

Ocean is a low range of north-trending mountains, called the Serranía de Baudó, which is drained on the east by the Baudó River and on the west by smaller streams which flow directly to the Pacific. The Serranía de Baudó has altitudes ranging from 1,600 to 3,300 feet. A still lower range of hills, called the Serranía de Istmina, trends east-northeast and forms a divide between the drainages of the San Juan and Arato Rivers. This range rises eastward to a peak called Alto de Fernando in the Cordillera Occidental, with an altitude of 9,400 feet.

\section{GENERAL GEOLOGY}

The rocks exposed in the Intendencia del Choco range in age from Precambrian to Tertiary, and strike generally northward, though in the upper valley of the San Juan River the regional strike veers to a direction ranging from N. $20^{\circ}$ E. to N. $40^{\circ}$ E. The stratigraphic sequence within the area whose drainage is shown in figure 7 comprises undifferentiated Mesozoic rocks, Cretaceous rocks, and lower and upper Tertiary rocks. Precambrian and post-Jurassic intrusives are also present. 
The formations of genetic significance are two sedimentary Tertiary formations, described as upper and lower Tertiary in age, and a band of post-Jurassic intrusive rocks that lie east of the Tertiary rocks. The distribution of the lower Tertiary rocks and of the post-Jurassic intrusives, as they occur in the eastern part of the province of Chocó, are also shown in figure 7. Another and wider band of the lower Tertiary rocks occurs in the Serranía de Baudó, and between these two bands lies a broad stretch of upper Tertiary rocks, which attain a maximum width of 50 miles. West of the Serraní de Baudó, the upper Tertiary rocks reappear, and continue to the Pacific Ocean. Cretaceous and undifferentiated Mesozoic rocks form the country rock east of the Tertiary formations and the post-Jurassic intrusives. The distribution of the bedrock units suggests the presence of a broad shallow synclinal basin of Tertiary rocks, more tilted on its eastern than on its western flank. A sharp anticline is also indicated in the Serranía de Baudó. Quaternary alluvium occupies the valley floors of the San Juan and Atrato Rivers and their tributaries, mainly in the area occupied by the upper Tertiary rocks.

The lithologic character of the Tertiary rocks has not been described. The bedrock in streams where placer mining has been done includes both the upper and lower Tertiary formations, but consists dominantly of the upper Tertiary rocks, which from brief statements are inferred to consist mainly of gritty sandstone, conglomerate, and shale. Where such rocks are exposed in the beds of streams and along stream terraces, they are weathered to a red caliche, which is widely distributed. This red caliche is a gravelly clay, of which about half consists of well-rounded pebbles, cobbles, and boulders up to a foot in diameter. The lithology suggests that the upper Tertiary rocks are of terrestrial origin; the origin of the lower Tertiary rocks is not known. Nearly all the gravels of the upper Tertiary rocks are so greatly weathered that they may be broken by hand, though obviously they were not in this condition at the time of their deposition. The lithologic character of these upper Tertiary gravels is inferred to be virtually similar to the gravels of the present streams. Below the red caliche at many places, according to Singewald (1950, p. 173), is a gray caliche, which crops out, however, mainly in the area southwest of the Condoto and Cajón Rivers.

The post-Jurassic intrusive rocks have been mapped in a belt 2 to 7 miles wide, which extends from the headwaters of the Andágueda River, and they probably extend for some distance southward into the province of Caldas. These intrusives consist mainly of dioritic and gabbroic rocks, but include also some ultrabasic types. According to Duparc and Tikonowitch (1920, p. 478-483), the ultrabasic rocks occur mainly in isolated mountains that lie west of the main Cordillera Occidental; these include Cerro Torá, Cerro Iró, and Cerro Muñoa (Imperial Institute of Great Britain, 1936, p. 109). The approximate position of Cerro Iró is shown in figure 7. Duparc and Tikonowitch (1920, p. 479) describe these ultrabasic rocks as dunite, pyroxenite, and picrite and regard them as the primitive sources of the platinum metals. They further state that along the east side of Cerro Iró these rocks are in contact with a thin slice of more or less siliceous schists, to the west of which lie upper Tertiary shale, sandstone, and conglomerate.

The ultrabasic rocks were evidently bared to erosion in pre-late Tertiary time, so that a part of the precious metals originating in lodes to the east were deposited in the late Tertiary sediments, which thus constitute a secondary or proximate source of gold and platinum. The red caliche, which is the product of weathering of the upper Tertiary rocks, is therefore auriferous and platiniferous and owing to residual concentration probably contains more of these metals than the underlying unweathered horizons. At many localities, the Tertiary rocks and the caliche derived from them contain enough gold and platinum that they may be dredged, and thousands of natives are engaged in mining these deposits on a small scale. The gray caliche, where it occurs at the base of the fluviatile placers, is reported by Singewald $(1950, \mathrm{p} .171)$ to be mainly barren of gold and platinum; and this is confirmed by Mr. O'Neill.

\section{GOLD-PLATINUM PLACERS}

All the deposits of the platinum metals so far found in Colombia are gold-platinum placers, wherein the ratio of gold to platinum varies from valley to valley. Moreover, except in a few tributaries of the San Juan River, the content of gold is greater than that of the platinum metals. Some of the characteristics of the platinum metals are stated in the descriptions of mining, but it should be added that a large part of the platinum is ferromagnetic. Iron pyrite is invariably one of the minerals in the concentrates recovered in the gold-platinum mining.

Gold lodes have been discovered in the headwaters of some of the streams of the Choco district that head in the Cordillera Occidental, but no platinum lodes have been found. Certain isolated mountains along the west flanks of the Cordillera Occidental, however, are known to be the sites of intrusive rocks that include ultrabasic rocks which are considered to be the 
primary sources of the platinum metals of the Chocó district.

The placer deposits include both stream and bench deposits. The stream placers were worked first to shallow depths by manual methods, and later to greater depths by machinery. The alluvium of the stream channels is underlain by red caliche which at many sites contains sufficient precious metals to be minable downward to the white caliche. Hence in working laterally outward from the stream gravels of the valley floor, no sharp demarcation exists between stream and bench deposits, except on high terraces or flats that are physiographically distinct. The high caliche flat, called the Big Flat, between the Condoto and Tamaná Rivers, exemplifies a terrace that may properly be called a bench deposit.

The gold-platinum placers of the Choco district are mainly in the valleys of the San Juan River and the Atrato River and their tributaries, but those of the San Juan basin are the principal sources of the platinum metals, as most of the deposits of the Atrato basin are dominantly gold placers. The valley of the San Juan River has been mined from its headwaters to its mouth, and its eastern tributaries that have been or are being mined are the Iró, Condoto, Opogodó, Tamaná, Nóvita, Cajón, and Sipí Rivers. The town of Opogodó, in figure 7, lies on the north bank of the Opogodó River. The Mungará and the La Platina Rivers are headwater tributaries of the San Juan River. Four headwater tributaries of the Condoto River are the Tajuato, Apogo, Mestizo, and Tajuato Rivers. The Quebrada Carmen, hereafter mentioned, drains into the Nóvita River.

The principal streams in the Atrato basin that are mentioned as sources of the platinum metals are the headwaters of the Quito River (also called the San Pablo River) and two eastern tributaries of the Atrato River, called the Cértigui and the Andágueda Rivers. Placer mining has also been done on the Baudó River, but the deposits have not proved to be very important; and as gold is the principal precious metal, little platinum comes from this source.

The paystreak in the valley of the San Juan River extends from its headwaters downstream for 40 miles, by the course of the stream to the mouth of the Sipi River and has been mined throughout that distance. Parts of the valley, however, are still being mined and will probably continue to be worked for some years to come. The width of the paystreak has generally exceeded 200 feet, and in the Big Flat area, from the mouth of the Opogodó River to the Condoto River, the paystreak has a width of more than 3 miles. Farther downstream on the San Juan River is a paystreak from
300 to 1,000 feet wide, which will be worked in later years. Dredge 6, of the International Mining Corp., was working in 1963-64 in the San Juan Valley at the west side of the Big Flat, in the vicinity of Chiqui Choqui, about $11 / 2$ miles airline upstream from the mouth of the Opogodó River. This is a swampy area in which the depth to bedrock ranges from 40 to 60 feet, of which the upper 9 feet consist of soil. The gravel is of medium size and consists of about 5 percent quartz, with country rock from the east constituting the remainder. The bedrock is a gray to black caliche, which is soft and sticky, and contains no precious metals. Gold and platinum occur in the gravels from 10 to 60 feet above bedrock, but mainly at a depth of 20 to 30 feet below the surface. Considerable black sand is recovered with the precious metals. Screen analyses show that the sizes of the platinum grains range from 20 to 200 mesh, but 29 percent of them are of size 65 mesh, or about 0.0082 inch in maximum diameter. The platinum-gold ratio of the recovered metals is $1: 1.7$.

The Big Flat is an irregular area bounded by the Condoto, San Juan, and Tamaná Rivers, and the Opogodó River is the principal stream that dissects it. Dredge 3 was working in this flat in the Opogodo Valley in 1963-64, and mining has been extended to both sides of the river. The average depth to bedrock is 31 feet, of which soil forms the uppermost 8 feet. The bedrock is gray caliche, but at this site there is a gradual change from the red to the gray caliche. Most of the precious metals are found about 2 feet above bedrock, though at some sites they are found throughout the alluvium under the soil. The gravels are well rounded and medium to small in size and include about 10 percent quartz. The remainder consist of country rocks from the Cordillera Occidental, which are greatly decomposed and soft. The rocks differ in this respect from those at the site of dredge 6 . Screen analyses of the platinum metals show that the grains range in size from 20 to 200 mesh, but a third of them are of size 65 mesh, or about 0.0082 inch in maximum diameter. The average platinum: gold ratio is about $1.6: 1$.

Dredge 2 was operating in 1963-64 in the Nóvita and Carmen valleys, in a large flat that is between the Tamaná and the Cajón Rivers. This is similar to the Big Flat that stretches from the Tamaná River to the Condoto River. The area is swampy and the depth to bedrock is 2.9 feet. The gravels are small and wellrounded and the consist of about 5 percent quartz, and all but the quartz are greatly decomposed. The bedrock is a soft sticky gray caliche. Most of the precious metals are concentrated on bedrock, but some of them extend upward into the gravel for 6 or 7 feet. Red garnet constitutes an important part of the concen- 
trates recovered with the precious metals. Screen analyses show that the sizes of the platinum grains range from 20 to less than 200 mesh, with 1 percent smaller than 200 mesh. About half the grains range in size from 100 to 150 mesh, or with maximum diameters from 0.0058 to $0.0041 \mathrm{inch}$. The production of precious metals at this site is dominantly gold, with a platinum: gold ratio of 1:7.6. The fact that much of this platinum is silvery in color suggests the presence of osmiridium.

The Tamaná River has a paystreak that extends from its confluence with the San Juan River upstream for about 16 miles by the course of the stream, and has been mined throughout that distance. Dredge 4 was operating in 1963-64 in the riverbed of the Tamaná River and adjacent flats, near Tambito, which is at the upper end of the paystreak. The average depth to bedrock in the valley floor is 9 feet, but in the adjacent flats it is about 35 feet. This operation is within an area shown in figure 7 as lower Tertiary rocks, and the bedrock here is a hard black to gray shale, locally decomposed. The overlying gravels are large, with a third of them having diameters between 6 inches and 3 feet. Quartz constitutes about 10 percent of these gravels. The gold and platinum are concentrated in a zone from 2 to 3 feet above bedrock. Pebbles of magnetite (or ilmenite) up to three-fourths of an inch in diameter are a prominent part of the semiheavy minerals of the concentrates. The gold is coarse grained, and the platinum is only a little smaller. Nearly half the grains of platinum range in size from 48 to 64 mesh, or with a maximum diameter ranging from 0.012 to 0.0082 inch. This operation produces little platinum, as the platinum:gold ratio is $1: 22.3$.

Little information is available concerning the length, width, depth, and general character of the other paystreaks in the Chocó district. The paystreak on the Condoto River, however, is known to have extended from its confluence with the San Juan River upstream for about 15 miles. The depth to bedrock is from 9 to 35 feet; the deeper ground being doubtless along the lateral limits of the paystreak. The platinum from the Condoto placers consists of small flattened white grains, most of which have maximum diameters ranging from 0.0085 to 0.0065 inch, but the smallest grains are as small as 0.0025 inch. In the headwaters, where the coarsest grains occur, they are found attached to is $3: 1$, which is said to be the highest in the Chocó dis(1956), the platinum: gold ratio on the Condo River is $3: 1$, which is said to be the highest in the Chocó district but this ratio is known also to be high in the valley of the Iró River. The concentrates recovered from the Condoto placers include ilmenite, a little magnetite, chrome spinel, chromite, garnet, pyrite, olivine, epidote, and a little zircon.

The stream gravels that form the workable placers in the Chocó district are a hetreogeneous assortment of well-rounded pebbles and cobbles, with some boulders similar, except for extreme weathering, to thoso present in the red caliche. They include numerous kinds of rocks eroded from the Cordillera Occidental and the rocks that bound this mountain range on the west. Shale, derived probably from the Cretaceous and early Tertiary rocks, is reported by Singewald (1950, p. 170) to constitute the principal gravels of the San Juan Valley, though fine-grained basic rocks, diorite, and graywacke were also noted. Other observers have reported the presence of some gravels consisting of schist, gneiss, diabasic greenstone, various intrusive rocks, lavas and basic and intermediate composition, conglomerate, and serpentine. Pebbles in quartz are not plentiful, but commonly constitute 5 to 10 percent of the gravels.

Tenors of some of the stream deposits mined in earlier years have been published, but in an area where many of the placers have been worked and reworked for scores of years, such tenors have more historical value than present significance. One estimate of this kind, made by a dredging company operating on the Condoto River in 1930, was an average tenor of $\$ 1.58$ per cubic yard, based upon mean values of the platinum metals and local gold bullion respectively of $\$ 65$ and $\$ 16.90$ per troy ounce. But the average tenor of the placers that are now being dredged is between 10 and 15 cents per cubic yard, based upon values of the platinum metals and gold respectively of $\$ 70$ and $\$ 35$ per ounce.

\section{NARIÑO PROVINCE}

Dredging began on the Telembi River, in the province of Nariño, in 1938. The dredge, now owned by the International Mining Corp., is larger and stronger than any of those operating in the Choco district, as it was designed to dig to a greater depth in more tightly consolidated gravel. This dredge, digging to a depth of 65 feet or less below water level, has worked from its initial site 9 miles downstream from Barbacoas up the valley of the Telembi River for 22 miles to the upper limit of dredging. It was moved in 1965 to a site below where it was constructed and has been modified to dig to a depth of 90 feet, to mine considerable reserves of such deeper ground. The width of this paystreak is not known to the writer, but it must be rather wide to have provided mining ground for 27 years. The gravels are mainly good sized cobbles of shale and slate, which are quite undecomposed and hard. The pre- 
cious metals occur generally close to bedrock. The output of platinum metals is small, because platinum constitutes only $1 \frac{1}{2}$ percent by weight of the gold that is recovered.

\section{ChEMTCAL ANALYSES}

The ratios of the six platinum metals to one another may be expected to vary considerably over an area so large as that heretofore described. These alloys include both ordinary platinum and osmiridium. Ten analyses of platinum metals are given in table 27. Three analyses of osmiridium are also available and are given in table 28.

Analyses, C, D, E and F appear to represent a single alloy consisting dominantly of platinum, with relatively small amounts of iridium and rhodium and still smaller amounts of palladium. Analyses $A_{2}$ and $B_{2}$

TABLE 27.-Analyses, in percent, of platinum metals from Colombia

[N.D., no data]

\begin{tabular}{|c|c|c|c|c|c|c|c|c|c|c|}
\hline & $A_{1}$ & $A_{2}$ & $\mathrm{~B}_{1}$ & $B_{2}$ & $\mathrm{C}$ & $\mathrm{D}$ & $\mathbf{E}$ & $\mathrm{F}$ & Mean $_{1}$ & $\mathrm{Mean}_{2}$ \\
\hline r..... & $\begin{array}{r}84.00 \\
1.56 \\
.59\end{array}$ & $\begin{array}{r}91.54 \\
1.59 \\
.64\end{array}$ & $\begin{array}{r}86.59 \\
1.50 \\
1.06\end{array}$ & $\begin{array}{r}92.33 \\
1.60 \\
1.12\end{array}$ & $\begin{array}{r}96.51 \\
1.32\end{array}$ & $\begin{array}{r}95.90 \\
2.26 \\
.20\end{array}$ & $\begin{array}{c}96.67 \\
-\end{array}$ & $\begin{array}{r}98.30 \\
-\end{array}$ & $\begin{array}{r}85.91 \\
1.54 \\
.57\end{array}$ & $\begin{array}{r}92.58 \\
1.66 \\
.62\end{array}$ \\
\hline & 2. 66 & 2. 90 & & & & & 2.74 & 1. 09 & 2. 11 & 2. 28 \\
\hline 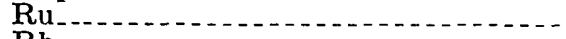 & N.D. & N.D. & N.I & N.D. & N.D. & .02 & -..... & $-\ldots .$. & .02 & 20 \\
\hline (n) & 2. 12 & 2. 30 & $\begin{array}{l}3.55 \\
1.09\end{array}$ & $\begin{array}{l}3.79 \\
1 .\end{array}$ & $\begin{array}{r}.90 \\
79\end{array}$ & $\begin{array}{r}.88 \\
74\end{array}$ & $\cdots--\frac{-}{5} \overline{9}$ & $-\overline{61}$ & 1. 90 & $\begin{array}{l}2.0 \\
.7\end{array}$ \\
\hline & $\begin{array}{l}.94 \\
.51\end{array}$ & & .76 & & .89 & & & & .53 & \\
\hline & 7. 72 & & 5.45 & & & & & & 7. 03 & \\
\hline Total_ & 0.00 & 100.00 & 100.00 & 100.00 & 100.00 & 100.00 & 100. 00 & 100.00 & 100.00 & 0 \\
\hline
\end{tabular}
A $_{1}$ Mean of five analyses (Kemp, 1902, p. 18, 19; Duparc and Tikonowitch,
$1920, \mathrm{p} .250$ and 189), Including copper and iron.

A2. Same as $A_{1}$, without copper and iron.

B1. Codaz21 (1929, p. 199-213), including copper and iron.

$B_{2}$. Same as $B_{1}$, without copper and iron.
C. Analysis by Johnson, Matthey and Co.

TABLE 28.-Analyses, in percent, of osmiridium from Colombia [N. D., no data]

\begin{tabular}{|c|c|c|c|c|c|c|}
\hline & $G$ & $\mathbf{H}_{1}$ & $\mathrm{H}_{2}$ & I & Mean $_{1}$ & Meang $_{2}$ \\
\hline $\begin{array}{l}\text { Pt. } \\
\text { Ir } \\
\text { Os } \\
\text { Ru } \\
\text { Rh } \\
\text { Pd } \\
\text { Cu } \\
\text { Fo } \\
\text { Fo }\end{array}$ & $\begin{array}{l}0.10 \\
7.40 \\
17.20 \\
\text { N.D. } \\
12.30 \\
\text { N.D. } \\
. . .\end{array}$ & $\begin{array}{r}\text { N.D. } \\
57.76 \\
35.08 \\
6.37 \\
.63 \\
\text { N.D. } \\
.06 \\
.10\end{array}$ & $\begin{array}{r}\text { N.D. } \\
57.86 \\
35.13 \\
6.38 \\
\text { N.D. } \\
. D 3 \\
\end{array}$ & $\begin{array}{r}\text { Tr. } \\
33.89 \\
54.55 \\
.96 \\
10.60 \\
\text { N.D. } \\
\text { Tr. }\end{array}$ & $\begin{array}{r}\text { N.D. } \\
57.76 \\
35.08 \\
6.37 \\
.63 \\
\text { N.D. } \\
.06 \\
.10\end{array}$ & \begin{tabular}{r}
0.10 \\
53.36 \\
35.17 \\
3.62 \\
7.75 \\
N.D. \\
\hdashline \\
\end{tabular} \\
\hline Total ................ & 100.00 & 100.00 & 100.00 & 100.00 & 100.00 & 100.00 \\
\hline
\end{tabular}

G. Kemp (1902, p. 21), without copper and iron.

$\mathrm{H}_{1}$. Kemp (1902, p. 21), including copper and iron.

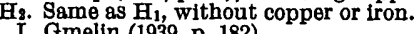

Mean. Mean analysis, including copper and iron. Mean2. Mean analysis, without copper and iron.

may include small amounts of intergrown or intermixed osmiridium. The analyses of table 28 indicate that the osmiridium represents a single alloy consisting dominantly of iridium and osmium, with less ruthenium and still less rhodium. These analyses indicate that the osmiridium alloy of Colombia appears to vary considerably in composition, ranging in tenors of iridium from 70 to 34 percent and in osmium from 17 to 55 percent. The mean analysis of the Colombian osmiridium correlates approximately with that from the Syssertsk area in the Urals, except that its mean tenor in rhodium is nearly five times as great as that of the Uralian product. A feature of this and of every
D. Big Flat. Analyst, E. R. Johnson. Published with permission of Johnso n Matthey and Co.

E. San Juan River (Singewald, 1950, p. 174)

Mean. Weighted mean analysis, including copper and iron.

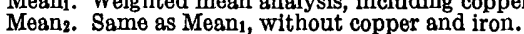

other osmiridium known to the writer is the low content of iron and copper. This is due doubtless to the limited miscibility in solid solution of these base metals with osmium and ruthenium, which together constitute generally about 10 to 15 percent of the placer platinum.

Platinum metals have been found in four Australian states; and in earlier years a considerable production resulted, but since 1958 the output has amounted to only a few ounces per year. The formerly productive states, named in their order of relative importance, are Tasmania, New South Wales, Victoria, and Queensland. Osmiridium was discovered in Tasmania in 1876, and from 1899 until recent years, a production resulted which has amounted to about 31,400 ounces, with a maximum output in 1925 of 3,665 ounces. Platinum was found in New South Wales in 1851, and the total production from 1893 to the present time is estimated to have been about 20,000 troy ounces, with an output of 336 ounces in 1932. Victoria produced 311 ounces of platinum metals in 1911 and 1913, as the byproduct from a copper mine, but no further output is recorded. Platinum has also been found at other localities in Victoria. Small amounts of platinum metals have been found in several goldfields of Queensland, and the platinum metals occur aiso on the 
oceanic beaches that extend southward into New South Wales. No production has been recorded.

\section{TASMANIA}

An excellent statement on the osmiridium deposits of Tasmania has been published by the Imperial Institute of Great Britain (1936, p. 78-84), and most of the material presented below was taken from that source. Osmiridium has been found in two principal areas in Tasmania, and from 1910 to 1922, when osmiridium began to be mined in the Witwatersrand, the Tasmanian osmiridium was the world's principal source of this alloy.

The two productive districts are known as the Heazelwood district, of northwestern Tasmania, and the Adamsfield district, of southwestern Tasmania. Osmiridium was first discovered in the Heazelwood disstrict in 1876, in the valley of Wilson River and shortly thereafter in the valleys of Savage and Whyte Rivers. These three streams are tributaries of Pieman River, which discharges into the ocean about 70 miles south-southeast of the northwestern point of Tasmania. About 1899, osmiridium was traced up the valley of Savage River to its confluence with Nineteen Mile Creek, and up that stream to its bedrock source on Bald Hill. Other headwater tributaries of Savage and Whyte Rivers were likewise found to contain highgrade placers, and the Bald Hill area, within the Heazelwood district, soon became the principal source of osmiridium in Tasmania. A workable placer was also found in 1903 on Trindle Creek, in the Wilson River area. Ordinary platinum was also found in the Heazelwood district.

Bald Hill is part of an irregular body of serpentinite within an area of about 20 square miles, which lies north of a much larger mass of granitic rocks. South of these granitic rocks is a large dike of serpentinite with a length of about 11 miles and a maximum width of $11 / 2$ miles, which trends southeast. This is transected diagonally by Wilson River, which flows generally parallel to the Savage and Whyte Rivers. Ten or more smaller bodies of serpentinite lie east of the two main ones, and one lies south of the northern one. According to a geologic map of Tasmania (Tasmania Geological Survey, 1961), these bodies of serpentinite are of Cambrian age and intrude sedimentary rocks of Precambrian age. The total length of this Heazelwood belt, including the granitic rocks from Savage River to the vicinity of Dudas, is about 35 miles. The bedrock on Bald Hill consists of dunite, bronzitite, and peridotite, including serpentinite, and eventually a bedrock source of osmiridium was found along structural planes in the ultrabasic rocks, mainly within an area of about 500 acres. These bedrock sources, however, were too low grade for successful mining, except where they were so greatly weathered that they could be mined as detrital deposits.

Most of the osmiridium was recovered from placers, of which three sources were recognized. These were first, the weathered serpentinite atop Bald Mountain; second, the eluvial and stream placers; and third, certain buried placers that were covered by lava flows of Tertiary age. The eluvial and residual deposits were quickly exhausted, and one buried stream placer on Nineteen Mile Creek was worked by under. ground methods. The stream placers ranged in width from 30 to 150 feet, and in depth to a maximum of 15 feet. The osmiridium ranged in size from very fine grains up to nuggets that weighed several ounces, but little or no platinum was commonly found. The heavy minerals recovered with the osmiridium included gold, gold alloyed with platinum, chromite, picotite, magnetite, pyrrhotite, and pyrite.

The second platinum field of Tasmania is the Adamsfield district, which was discovered in 1925 and soon superseded in importance the deposits of the Heazelwood district. This district is in the northeastern part of Arthur County, southwestern Tasmania, about 55 miles west-northwest of Hobart. The general area is in the valleys of Adams and Eve Creeks, extending northward to Gordon River. The principal stream valleys from which osmiridium was recovered were those of Main and Lavelle Creeks and smaller tributaries of these two streams. The Adamsfield district yielded 12,500 ounces of osmiridium between 1925 and 1934, and progressively smaller amounts in later years.

The geology of the Adamsfield district is shown on a geologic map of Tasmania (Tasmania Geological Survey, 1961). The country rocks are of Precambrian, Cambrian, Silurian, and Devonian age, and a large dike of ultrabasic rock of Cambrian age is shown to invade the Precambrian sedimentary rocks. This dike trends north-south and has a length of 10 miles, and a width ranging from 1 to $12 / 3$ miles. It consists mainly of serpentinite, and has been proven to be the bedrock source of the osmiridium. In 1930, a lode deposit of osmiridium was located in the serpentinite and was worked successfully for several years. The ore body is a steeply dipping body of foliated serpentinite which lies between well-defined walls of dark-green massive serpentinite. The length of this ore body was about 700 feet, with a width ranging from 8 to 10 feet. The osmiridium was found to be distributed in veins that had a maximum thickness of 18 inches. The ore body was so softened by weathering that it could be disintegrated by a 
giant and was therefore mined mainly as a detrital deposit, though it is recorded that equipment for crushing bedrock was installed in 1933.

Most of the production, however, came from stream placers that yielded mainly osmiridium, with a very small amount of native gold. The detrital minerals recovered with the osmiridium included a large volume of chromite, together with ilmenite, zircon, topaz, millerite, and pyrite, of which the two last mentioned were thought to be of secondary origin. Intergrowths of osmiridium and gold suggested a hydrothermal origin for both metals.

Platinum and palladium were also found in Tasmania, though not in economic quantity, in a coppernickel lode mine near Zeehan, which is situated on Badger River, a short distance west of Dundas. According to The Imperial Institute of Great Britain (1936, p. 83), this deposit contained ore minerals with a tenor of 6 percent nickel, 3 percent copper, and a little gold, platinum, and palladium. The lode consisted of veins 1 to 4 feet thick, within bodies of gabbro, norite, and other basic intrusives.

Four analyses published by Quiring (1962, p. 120) of the platinum metals of Tasmania have been recomputed to total 100 percent, without the base metals, and are given in table 29 . The Tasmanian osmiridium, represented by analyses $\mathrm{A}, \mathrm{C}$, and $\mathrm{D}$, may properly be called iridosmine, as the tenors of osmium are invariably greater than those of iridium. Its nearest counterpart is the iridosmine of the Witwatersrand, but the total iridium plus osmium is considerably higher than that of the Witwatersrand, and the tenor in rhodium is only half as great. The small content of platinum shown in analyses $\mathrm{A}, \mathrm{C}$, and $\mathrm{D}$ indicate the presence only of a single alloy, rather than osmiridium intergrown with the common platinum alloy. Analysis B appears to represent a mixture of ordinary platinum

TABLE 29.-Analyses, in percent, of osmiridium and platinum from the Heazelwood and Adamsfield districts, Tasmania

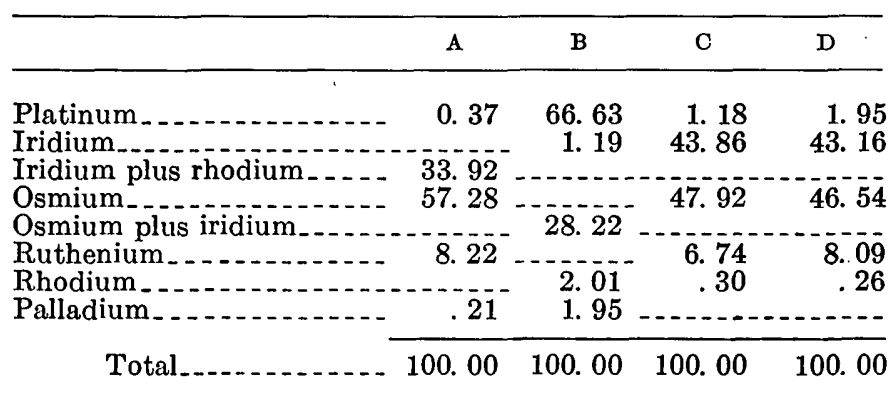

A. Osmiridium from the Heazelwood district.
B. Platinum from the Heazelwood district.

C. Mean of 31 analyses of osmiridium from the Adamsfeld district, originally pub-

D. Mean of an unspecifled number of analyses from the Adamsfield district, made originally by Johnson, Matthey and Co., Ltd., of London. and osmiridium, of which the former is a major component.

The Tasmanian osmiridium has not merely a very high tenor in osmium and iridium, but also a very low tenor in platinum. It is well known that the solubility of one chemical element may be appreciably influenced by the presence of another element with a different solubility. Beamish stated $(1966$, p. 21) that the Tasmanian osmiridium (iridosmine) is more resistant to chlorinization that any other known osmiridium. Platinum is readily soluble in aqua regia, and it is possible that its paucity in the alloys represented by analyses $A, B$ and $D$ may explain the resistance of this osmiridium to chlorinization.

\section{NEW SOUTH WALES}

Platinum was first discovered in eastern New South Wales in 1851, in alluvial deposits near Orange, in Wellington County. The most important area, however, is the Fifield district of Cunningham and Kennedy Counties, in east-central New South Wales, about 215 miles N. $65^{\circ} \mathrm{W}$. of Sydney and between the Lachlan River and the headwaters of Bogan River. This field was discovered in 1887, and beginning in 1893 soon became the largest producer of platinum metals in this state. For the first 30 years after 1893, the total output was about 20,000 ounces; thereafter, the deposits continued to be worked with steadily diminishing returns.

The bedrock formations of this area are mainly slate, sandstone, and limestone of Silurian age, overlain by sandstone and conglomerate of Devonian age. The platiniferous deposits consist of deeply buried gravels, probably of Pliocene age, which are covered by Pleistocene sediments of sand and clay, and locally by basaltic lava. These buried placers, called "leads," are less deeply buried and therefore more accessible toward the headwaters of the streams that formed them. The original discovery in this field was in a conglomerate on a low hill about 2 miles east of Fifield, but it is possible that this represents a remnant of an early Tertiary conglomerate that functioned as a proximate source of the precious metals for streams of late Tertiary age.

The Platina lead, discovered in 1893 , has a linear workable extent of a mile from north to south, and widths from 60 to 150 feet. The ancient stream that produced this placer evidently flowed south, as the tenors decrease in that direction. The previous metals consist of platinum and gold in ratios ranging from $6: 1$ to $3: 1$, and they occur either on or in crevices in bedrock or in gravel a few inches above bedrock. Nuggets of platinum weighing as much as 1.35 ounces 
have been recovered. A small amount of osmiridium is also present.

A similar deposit, called the North or Gillenbine lead, was discovered in 1917. This likewise extended north-south for about a mile, with widths ranging from 40 to 80 feet. The platiniferous gravel of this deposit lies 80 to 90 feet below the surface, and ranges in thickness from a few inches to 3 feet. The ancient streams at this site appears ito have flowed northward, as the tenors are highest at the south end of the lead. The ratio of platinum to gold is about $8: 1$.

Three analyses of the platinum metals of the Fifield district are available; these analyses, recomputed to total 100 percent without the base elements, are presented in table 30 . These analyses appear to represent the common alloy of platinum, with which was intergrown or intermixed some osmiridium, similar generally to the product from Platinum, Alaska. An exact comparison is not possible because ruthenium was not determined, and because in analysis B, palladium was not separated from rhodium.

$\mathrm{T}_{\mathrm{ABLE}}$ 30.-Analyses, in percent, of platinum metals, Fifield district, New South Wales

[N.D., no data]

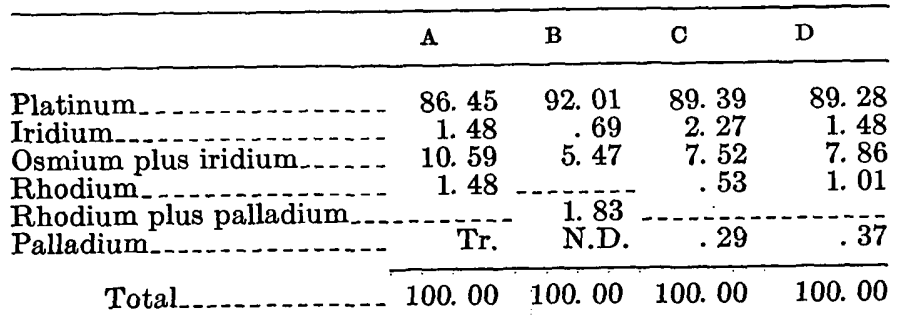

A. Platina lead, published by the Imperial Institute of Great Britain (1936, p. 76). B. North lead, (Morrison, $1928, \mathrm{p}$. 121).

D. Mean of analyses A, B, and C.

A less important area in New South Wales was the Richmond River district, which beginning about 100 miles south of Brisbane extended southward and westward for another 100 miles to include the valleys of Richmond and Clarence Rivers and continguous streams. The beach deposits at Ballina and Evans Head were also within this District. So far as can be learned, the Richmond River district never became very productive, but evidently osmiridium was one of the platinum alloys, as one analysis of osmiridium was published by O'Neill and Gunning (1934, p. 20). This analysis, recomputed to total 100 percent, is iridium 58.22 , osmium 33.50 , ruthenium 5.23, rhodium 3.05 , platinum and palladium not determined. This osmiridiim differs from that of the Witwatersrand and Tasmania in that the content of iridium is greater than that of osmium. It differs from the osmiridium of $\mathrm{Ja}$ - pan in having a much lower content of ruthenium and rhodium, and it differs from the Colombian osmiridium in that the content of ruthenium is greater than that of rhodium. The closest counterpart is the osmiridium from Syssertsk, in the Urals. These differences show the high variations that may be expected in osmiridium.

Considerable has been written about the occurrence of platinum at Darling Hill, in the Broken Hill district, about 265 miles northeast of Adelaide. These are lode deposits, exposed at several localities, of which none has proved to have any commercial value. The country rock in their vicinity consists of high folded sandstone and shale, intruded prior to folding by pegmatite, amphibolite, and serpentinite. The platinum metals occur either in lenticular veins of serpentinite, or in narrow veins of hematite and limonite, at or near the contacts between serpentinite and country rock. Copper, nickel, and cobalt, as well as the platinum metals, gold, and silver are present in the ores. The genesis of these deposits has not been definitely established.

\section{VICTORIA AND QUEENSLAND}

Platinum metals were produced in southeastern Victoria in the period 1911-13, as a byproduct from the Walhalla copper mine, Gippsland district, about 80 miles east of Melbourne. The average tenor of platinum metals at this mine was 0.13 ounce per ton of copper and gold ore, and the total production was 311 ounces. The character of the platinum metals has not been published.

The bedrock formations in this area, according to a geologic map published by the Victoria Department of Mines (London, 1963), are Ordovician slates and sandstones, intruded by granitic rocks of unstated age and character, with nearby basaltic volcanics of Tertiary age. The copper ore is chalcopyrite, which occurs in dioritic rocks. Platinum metals were also found in pipes and dikes in the Walhalla-Wood's Point district. Osmiridium was found near Foster, about 40 miles southeast of Melbourne, and in the Waratah Range, of south Gippsland.

Alluvial platinum and gold were first found in southeastern Queensland in 1869 at Brickfield Gully, in the Gympie goldfield, on Mary River, about 90 miles N. $15^{\circ} \mathrm{W}$. of Brisbane. Alluvial platinum has also been found in the Russell goldfield, near Innisfail, northeastern Queensland. Other localities are on Don River, about 40 miles south of Rockhampton, and along the oceanic beaches south of Brisbane, including Currumbin Beach, near the mouth of Tweed River. No production is recorded for Queensland. 


\section{NEW ZEALAND}

Osmiridium was discovered in New Zealand in 1860. Platinum and platiniridium are also known to occur, and Morgan (1927, p. 76, 77, and 81-82) has listed 45 known localities. Five sites are mentioned by The Imperial Institute of Great Britain (1936, p. 86) and by O'Neill and Gunning (1934, p. 128) where the platinum metals occur in lode deposits; two in quartz veins, two in pyritic quartz veins, and one in massive pyrite. Three of these localities are on the North Island, and two on the South Island. None of the lode deposits has proved to be workable; and of the alluvial deposits, only those at the south end of the South Island have been mined.

The principal output of alluvial platinum came from the southern beaches of Southland, where an annual production of less than 20 ounces was made for several years and where the total production is estimated to have been between 100 and 200 troy ounces. The productive sites were along the north side of Foveaux Strait, from some point west of the mouth of the Waiau River east-southeast to the mouth of the Waikawa River, a distance of about 90 miles. These deposits occur both on the present and on the elevated beaches. The coarsest platinum came from the beach west of the mouth of the Waiau River. The principal precious metal is gold, and the highest recorded ratio of platinum to gold is $1: 4$, near Waiau River. Ratios as low as 1:100 are also known elsewhere on these beaches. In Nelson province, in the northwestern part of the South Island, platinum was also found in the gravels of Lee, Roding, and Maitai Rivers, but no production is recorded.

Analyses of the osmiridium and platiniridium of New Zealand have not been published. One analysis, however, of the platinum metals from Orepuki, South Island, was published by Farquharson (1913, p. 471). This analysis recomputed to total 100 percent, with and without iron and copper, is as follows:

\begin{tabular}{|c|c|c|}
\hline & $\mathbf{A}_{1}$ & $\mathbf{A}_{2}$ \\
\hline $\begin{array}{l}\text { Platinum } \\
\text { Iridium } \\
\text { Osmium plus iridium } \\
\text { Rhodium } \\
\text { Palladium } \\
\text { Iron } \\
\text { Copper }\end{array}$ & $\begin{array}{r}\text { 74. } 36 \\
1.30 \\
\text { 14. } 27 \\
\text { 3. } 51 \\
\text { 1. } 35 \\
\text { 5. } 06 \\
.15\end{array}$ & $\begin{array}{r}78.44 \\
1.37 \\
15.06 \\
3.70 \\
1.43 \\
\hdashline\end{array}$ \\
\hline Total & 100.00 & 100.00 \\
\hline
\end{tabular}

This analysis suggests strongly that the analyzed product consisted of a major alloy of platinum, intergrown or mixed with a minor alloy of osmiridium. It resembles the high-iridium platinum metals found in the headwaters of Platinum Creek, of the Goodnews Bay district, Alaska.

\section{PAPUA, TERRITORY OF NEW GUINEA, AND NETHER- LANDS NEW GUINEA}

Alluvial osmiridium occurs at numerous localities in Papua and has been mined in a small way at several sites, with a maximum annual production of about 355 ounces in 1921, and a total production said by Quiring (1962, p. 101) to have been about 1,350 ounces. Osmiridium, mixed with gold in unknown proportions, occurs on the beach at Milne Bay, at the extreme southeastern end of the island of New Guinea. Two other localities mentioned by O'Neill and Gunning $(1934$, p. 128) are the Yodda and the Gira Rivers, of which the latter is north of Owen Stanley Range, and about 240 miles northwest of Milne Bay. Another known locality is the Brown River, on the South side of the Owen Stanley Range and about 250 miles west-northwest of Milne Bay. Platinum also was discovered in 1933 in the Papuan jungle, about 120 miles west of Samarai.

The distribution of these localities shows that osmiridium and platinum occur over a distance of at least 250 miles in eastern Papua; and inasmuch as the platinum metals are known to be present in nearly every goldfield in Papua and in the other two divisions of New Guinea, it is concluded that these metals have a very wide distribution. According to E. R. Stanley $(1932$, p. 56), there are many areas and belts of peridotite and serpentinite in the mountain range that crosses New Guinea; and he surmised that the platinum metals might be found in the valleys of many streams that drain this range. This is further indicated by the discovery of platinum in the headwaters of Ramu River, north of Bismarck Range, in the Territory of New Guinea.

\section{BORNEO AND SUMATRA}

Platinum was discovered in Borneo in 1831, and from that date to 1922 , it is estimated by Quiring $(1962$, p. 93$)$ that the total production has been about 53,700 troy ounces, with a maximum of about 2,890 troy ounces for the period 1866-90, or an average annual production for these 5 years of about 580 ounces per year. Borneo has not been productive for many years.

Platinum and osmiridium were found both in the gold and in the diamond placers of southeastern $\mathrm{Ka}$ limantan, Borneo, and also in West Borneo between South Borneo and Sarawak. The richest deposits were apparently in the gold-platinum placers of GoenoengLawack, near the boundary between the Tanah-Laut 
and Martapura, east of Bandjarmasin. Stauffer (1945) corroborates the recovery of small amounts of platinum, together with diamonds, from the placers of Martapura. The streams of this area, according to the Imperial Institute, drain the Bobaris Mountains. Kemp $(1902$, p. $82-83)$ also mentions in the same region the Banjermassing River, which drains the Ratoos Mountains. The bedrock in these mountains evidently includes dikes and larger bodies of serpentinite, gabbro, and diorite; and the platinum and osmiridium are doubtless derived from the basic and ultrabasic rocks. The ratio of gold to platinum is stated to range from $9: 1$ to $10: 1$, and in the diamond placers, the ratio of diamond to platinum is about $1: 1$. Concentrates recovered from the gravels are stated by different writers to include chromite, cinnabar, topaz, zircon, and diamond.

Four analyses of platinum (table 31) and four analyses of osmiridium (table 32 ) are available for the Goenoeng-Lawack region, Borneo.

TABLE 31.-Analyses, in percent, of platinum metals, GoenoengLawack region, Borneo

[Analyses recomputed to 100 percent. N.D., no data]

\begin{tabular}{|c|c|c|c|c|c|c|}
\hline & $\mathbf{A}$ & B & C & $\mathrm{D}$ & Mean $_{1}$ & Mean, \\
\hline $\begin{array}{l}\text { Platinum } \\
\text { Iridium } \\
\text { Osmium } \\
\text { Osmium plus iridium } \\
\text { Osmium plus ruthenium }\end{array}$ & $\begin{array}{r}73.98 \\
6.46 \\
1.21 \\
9.30\end{array}$ & $\begin{array}{r}74.64 \\
8.22 \\
.50 \\
8.75\end{array}$ & $\begin{array}{r}84.15 \\
.67 \\
.31 \\
3.87\end{array}$ & \multirow[t]{2}{*}{$\begin{array}{r}74.89 \\
3.18 \\
\text { N.D. } \\
9.23 \\
1.30 \\
.64\end{array}$} & $\begin{array}{r}76.57 \\
4.61 \\
.67 \\
7.76\end{array}$ & $\begin{array}{r}84.13 \\
5.06 \\
.73 \\
8.52\end{array}$ \\
\hline $\begin{array}{l}\text { Rhodium } \\
\text { Rhodium plus palladium }\end{array}$ & .53 & N.D. & N.D. & & .54 & .60 \\
\hline $\begin{array}{l}\text { Palladium } \\
\text { Iron } \\
\text { Copper }\end{array}$ & $\begin{array}{r}1.52 \\
6.11 \\
.89\end{array}$ & $\begin{array}{r}6.10 \\
.45\end{array}$ & $\begin{array}{r}10.87 \\
.13\end{array}$ & $\begin{array}{r}.24 \\
10.68 \\
.44\end{array}$ & $\begin{array}{r}.86 \\
8.51 \\
.47\end{array}$ & 96 \\
\hline Total.- & 0.00 & 100.00 & 100.00 & 100.00 & 100.00 & 100.00 \\
\hline
\end{tabular}

A, B. Nuggets (Bleckrode, 1858, p. 656; republished by Kemp, 1902, p. 82). C. Nugget (Böcking, 1855, p. 243; republished by Kemp, 1902, p. 82). D. Quiring (1962, p. 158)

Mean 1 . Mean of analyses A-D, including iron and copper. hout iron and copper.

TABLE 32.-Analyses, in percent, of osmiridium, Goenoeng-. Lawack region, Borneo

[Analyses recomputed to 100 percent]

\begin{tabular}{|c|c|c|c|c|c|c|}
\hline$\therefore$ & $\mathbf{E}$ & $F$ & $G$ & $\mathrm{H}$ & Mean $_{1}$ & $\mathrm{Mean}_{2}$ \\
\hline $\begin{array}{l}\text { Platinum } \\
\text { Iridium } \\
\text { Osmium } \\
\text { Ruthenium } \\
\text { Rhodium } \\
\text { Iron } \\
\text { Copper }\end{array}$ & $\begin{array}{r}3.13 \\
62.02 \\
30.56 \\
\mathrm{Tr} . \\
3.33 \\
.45 \\
.51\end{array}$ & $\begin{array}{r}1.93 \\
58.15 \\
38.30 \\
.25 \\
1.01 \\
.28 \\
.08\end{array}$ & $\begin{array}{r}0.10 \\
53.58 \\
35.31 \\
6.29 \\
4.67 \\
.02 \\
.03\end{array}$ & $\begin{array}{r}0.20 \\
17.25 \\
68.89 \\
9.03 \\
4.57 \\
.03 \\
.03\end{array}$ & $\begin{array}{r}1.34 \\
47.78 \\
43.24 \\
3.89 \\
3.39 \\
.20 \\
.16\end{array}$ & $\begin{array}{r}1.35 \\
47.95 \\
43.40 \\
3.90 \\
3.40 \\
\end{array}$ \\
\hline Total & 100.00 & 100.00 & 100.00 & 100.00 & 100.00 & 100.00 \\
\hline
\end{tabular}

E-H. Quiring (1962, p. 158)

Mean 1 Mean of analyses E-H, includiug iron and copper.

Means. Same as mean, without iron and copper.

Analyses A, B, C, and D (table 31), because they were made of nuggets, should yield a good value for the dross, of which the mean value is seen to be 8.98 percent. The fact that analyses A, B and D have high tenors for iridium plus osmium suggests that they are intergrowths of a major alloy of platinum with a minor alloy of osmiridium, but analysis $\mathrm{C}$ appears to represent a single alloy with a still smaller content of osmiridium. Analyses E, F, G, and H (table 32) represent alloys of osmiridium alone, but show variations of such a magnitude that they do not correlate closely with any others shown in this report.

Laurite, the sulfide of ruthenium and osmium, was first identified in Borneo by Wöhler (1866). The composition which he gave for this mineral, stated in percentages, was ruthenium 65.18, osmium 3.03 , and sulphur 31.79. Owing, however, to the small size of the sample available for analysis, Wöhler was uncertain of the correct formula that should be assigned.

Platinum occurs in Sumatra, but no production has been recorded. Sumatra is best known for a peculiar lode, which occurs in the province of Sumatera Utara, about 35 miles inland from Sibolga, near the main highway. This lode was described originally by Hundeshagen (1904, p. 550-552) and has been republished by other writers, notably O'Neill and Gunning (1934, p. 123-124). The deposit contains ore of grossularite and wollastonite, with some bornite and secondary malachite, which have resulted from the contact metamorphism of a layer or lens of limestone by an intrusion of granodiorite. Assays revealed a tenor in platinum of about 0.18 ounce per ton of ore, all of which appears to have been contained in the wollastonite. Stauffer (1945, p. 332) also states that platinum was recovered from metamorphosed limestone as a byproduct of the Bengkalis gold mines.

\section{JAPAN}

Platinum metals were first recognized in Japan about 1890 in the gravels of the Yubari and the Sorachi Rivers, tributaries of the Ishikara River, within the provinces of Iburi and Ishikari, in the western part of Hokkaido Island. Probably the most productive area was in the valley of the Uryu River, the principal headwater tributary of the Ishikara River. Other placers were found on the Obirashibe River, west of the Uryu River, farther north of the Teshio, Tombetsu, and other streams, and along the western beaches of Hokkaido Island, between Kawashri and Embetsu. Placers were also found south of the Ishikara River, on the $\mathrm{Mu}$, Hidaka, and other streams, and on certain beaches in the province of Iburi. Thus, the platinum deposits were confined largely to the western slope of Hokkaido. Other alluvial deposits, most of which were nonproductive, were found northward from Hitachi, on Honshu Island, on Sado Island off the west coast of Honshu Island, on Shikoku Island, and at other numerous sites, including the northeast coast of Hokkaido Island. Practically all the past production, 
however, has come from Hokkaido Island, and most tables in the literature concur in this generalization.

The data on past production are contradictory, and the evidence indicates that placer production has at times been compiled with production from refineries and even with imports of platinum metals. It is estimated by Quiring (1962, p. 101) that the total output from 1909 to 1933 was about 8,000 troy ounces, with a maximum production of about 1,770 ounces in 1918 . Pollard (1951, p. 8-9) has published a table based upon certain assumptions, which may or may not be valid. Taking, however, the minimum values given in his table, it appears that the total output from 1892 to 1950 , when production ended, was about 10,000 troy ounces and that the maximum production was in 1944 and 1945, when 687 and 647 troy ounces respectively were recovered. Most of the deposits were placers of osmiridium and gold, and the more important ones showed ratios of osmiridium to gold ranging from $3: 1$ to $9: 1$, but at one locality near Tomarinai, the osmiridium was almost free of native gold. At the less important sites, the ratios of platinum to gold were much lower.

The principal areas of serpentinite in Hokkaido are shown by Pollard $(1951$, p. 26$)$ to be coextensive with the osmiridium placers. Thus large bodies of serpentinite crop out in the upper valley of the Uryu River, and between the valleys of the Teshio and the Tombetsu Rivers in northern Hokkaido. Scattered, but important, bodies of serpentinite are also present in the valleys of the $\mathrm{Mu}$ and the Hidaka Rivers, northeast of Mukawa. The platinum metals have not been found in bedrock, but without doubt these metals originated in the serpentinite. Four types of alluvial deposits are known, of which the principal and most important ones are gravels in the present valley floors of streams that drain areas of serpentinite. A second type comprises terrace gravels in the same streams, which have altitudes up to 60 feet above the valley floor, and in some valleys extend laterally from the master stream as much as half a mile. These might amplify considerably the reserves of osmiridium, but have been little prospected. A third type of deposit, which may constitute a proximate source of osmiridium, are certain Tertiary conglomerates mentioned by Pollard (1951, p. 13). The fourth type constitute the beach placers.

The platinum metals are mainly osmiridium, which according to Pollard $(1951$, p. 3) constitute more than 80 percent of these metals, the remainder being ordinary platinum. The grains of osmiridium in the stream placers range in size from 30 to 100 mesh, or approximately from diameters of 0.02 to 0.006 inch; those on the beaches range from 100 to 200 mesh, with diameters approximately of 0.006 to $0.003 \mathrm{inch}$. The largest nugget known to have been found on Hokkaido Island weighed 0.315 troy ounce. The accessory minerals of the concentrates are mainly chromite and magnetite, though cinnabar has been recorded from some of the placers.

Four chemical analyses of the osmiridium are available and their values, recomputed to total 100 percent, are given in table 33. The tenor in iridium is higher TABLE 33.-Analyses, in percent, of osmiridium, Hokkaido Island, Japan [N.D., no data]

\begin{tabular}{|c|c|c|c|c|c|}
\hline & A & B & C & $\mathrm{D}$ & $\mathbf{E}$ \\
\hline $\begin{array}{l}\text { Platinum } \\
\text { Iridium } \\
\text { Osmium } \\
\text { Ruthenium } \\
\text { Rhodium }\end{array}$ & $\begin{array}{r}0.15 \\
50.37 \\
37.73 \\
7.78 \\
3.97\end{array}$ & $\begin{array}{l}\text { N.D. } \\
\text { 47. } 04 \\
35.78 \\
12.02 \\
5.16\end{array}$ & $\begin{array}{r}\text { Tr. } \\
43.10 \\
38.48 \\
12.52 \\
5.90\end{array}$ & $\begin{array}{r}\text { Tr. } \\
50.98 \\
33.08 \\
11.52 \\
4.42\end{array}$ & $\begin{array}{r}0.15 \\
47.82 \\
36.22 \\
10.95 \\
4.86\end{array}$ \\
\hline Total__-_..- & 100.00 & 100.00 & 100.00 & 100.00 & 100.00 \\
\hline
\end{tabular}

A. O'Neill and Gunning (1934), p. 124.

B. Gmelin (1939, p. 145). Mean composition of fine and coarse grains. $\mathrm{C}$ and D. Pollard (1951, p. 23). E. Mean of these four analyses.

than in the osmiridium of the Witwatersrand, and platinum and palladium are virtually absent. The osmiridium from Syssertsk, though somewhat similar in that iridium is more plentiful than osmium, differs, in containing some platinum and in having much lower contents of ruthenium and rhodium, and much the same comparison may be made with the osmiridium from Borneo. The osmiridium from Colombia contains twice as much rhodium as ruthenium. Owing to inferior analyses of the Tasmanian product, an accurate comparison cannot be made, but in general the Tasmanian osmiridium contains platinum and has a very low content of rhodium. A worldwide appraisal of all the known osmiridium, as described in this report, indicates that this alloy does not approach a constant composition, but shows instead marked differences in the contents of iridium, osmium, ruthenium, and rhodium. The common characteristic is that the content of platinum is low or lacking and that palladium is almost entirely absent.

\section{OTHER COUNTRIES}

Platinum metals are known to occur in certain of the nickel-copper deposits of Norway, but most of these were exhausted years ago. These metals appear to be contained in sulfides, especially in chalcopyrite, which occurs in or close to bodies of magmatic segregations of norite and gabbro. The ratio of platinum to palladium was about $1: 2$, and their combined tenor was reported to have been about 50 cents per ton of ore. According to Quiring (1962, p. 97), the total 
Norwegian output for the period 1927-38 was about 1,320 troy ounces, with maxima in 1930 and 1934 of about 190 ounces.

Refineries in Germany, Japan, and Italy, engaged in the refining of gold and copper, also contribute considerable amounts of platinum metals. In Germany, platinum and palladium are produced in processing the Kupferschiefer of the Mansfeld district, and these metals are also recovered in the refining of gold and copper. The extent of this industry in Germany has been reported by Rhodes, Jahn, and Dowson (1945, 53 p.).

The amounts of platinum and palladium recovered from the Mansfeld Kupferschiefer in 1929, according to Quiring (1962, p. 148), were respectively 0.0000167 and 0.0000138 ounce per ton. Quiring also cites $16 \mathrm{~min}$ erals that have been found in different parts of Germany, which had tenors in the platinum metals ranging from 0.0032 to 0.157 ounce per ton, but these were not minable ore deposits. The highest tenor was in a psilomelane from the Harz Mountains.

A locality in Guyana is of interest because it was the site of the discovery in 1923 of potarite, a rare compound of palladium and mercury. This was found near the Kaieteur Falls of Potaro River but was later found over an extensive area in the Potaro district. According to Spencer (1928), potarite is a definite compound of palladium and mercury in equal atomic proportions, but in this paper it is classified as a palladium amalgam. Platinum has also been reported in the Lawa River, in Surinam.

Platinum was first discovered in 1904 in the gold placers of Madagascar, where it was recovered at several localities; but the annual production never exceeded 10 ounces. One particular locality, given by The Imperial Institute of Great Britain (1936, p. 98), is of interest because an analysis was made of the platinum metals. This site is about 40 miles northwest of Vangaindrano in the valley of the Isonjo River, a tributary of the Manambia River, a left limit tributary of the Mananara River. A chemical analysis of this alluvial platinum, recomputed to total 100 percent, with and without iron and copper, is as follows:

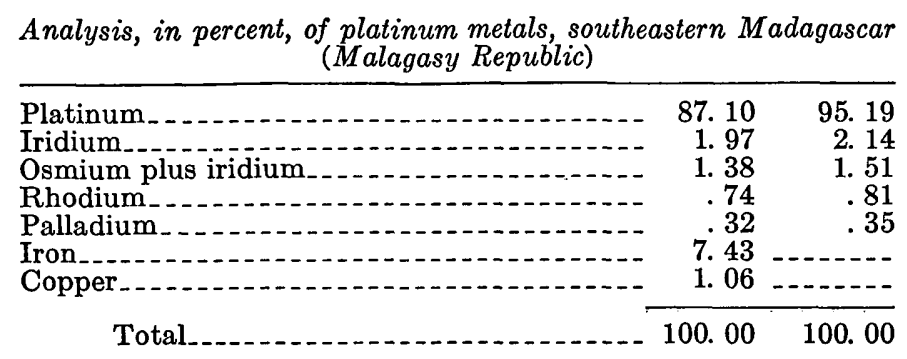

This analysis indicated the absence of osmiridium.
Platinum and osmiridium have also been found in the auriferous gravels of the rivers draining both slopes of the Patkoi Range between northern Burma and Assam. A small amount of platinum was definitely recovered, according to The Imperial Institute of Great Britain (1936, p. 73), from the headwaters of the Irrawaddy River, north of Myitkyina. Platinum has also been described from numerous other localities in Burma, but no production has resulted.

\section{UNITED STATES}

Platinum metals have been found at many localities in the United States, but significant amounts of these metals have been produced at only three places. The principal source of platinum metals has been the placers of the Goodnews Bay district, western Alaska; another Alaskan source was a copper lode on Kasaan Peninsula, southeastern Alaska, which was worked for a number of years; and the third source has been the dredges of California, which for many years produced small amounts of platinum metals as a byproduct of gold placer mining. Smaller amounts of platinum have similarly been recovered from the gold placers of Oregon and Washington, and minor amounts from the placers of Montana, Idaho, and other Western States. A very small output has also come from some of the gold placers of Alaska.

Lodes that contained the platinum metals have been prospected and worked on a small scale in Wyoming, Nevada, Montana, and Colorado. In addition to these cited occurrences, traces or small amounts of the platinum metals have been found in 13 other States, as shown in table 10. Some of the minor deposits that have scientific interest will be briefly discussed, though none of them has economic significance.

\section{ALASRA \\ LODES \\ SALT CHUCK MINE}

The Salt Creek mine, formerly called the Goodro mine, is at the northwestern extremity of Kasaan Peninsula, about 36 miles N. $60^{\circ} \mathrm{W}$. of Ketchikan. This property was described in considerable detail by Wright $(1915$, p. 99) at the time of his visit in 1908, when it was recognized as a small producing copper mine. The ore deposit differs from most others in that vicinity in that bornite is the principal copper-bearing mineral, though the ore also includes chalcopyrite, with small amounts of chalcocite, native copper, and gold. These ore minerals occur as small masses and disseminations in pyroxenite, gabbro, and gabbro pegmatite, all of which are differentiated products of the regional granitic rocks. The principal rock- 
forming mineral is augite, in addition to which are biotite, iron ores, plagioclase, apatite, and sphene. The pyroxene and plagioclase are locally much altered to epidote, and to chloritic and sericitic minerals.

The Salt Chuck ore, until 1917, had been rated as a small low-grade copper deposit, with a mean tenor of 1.4 percent copper and a small byproduct of gold and silver. In 1917, however, the owners of this property discovered that their ore also contained platinum metals, which thenceforth became the principal product of mining. The property was visited in 1917 by the writer, (Mertie, 1920, p. 17-20) shortly after this discovery was made, and he was able to describe the deposit in the light of this new information. The country rock is much fractured, but most of the copper ores occur as disseminated deposits in irregular ore shoots. Some of the Chalcopyrite, however, occurs along planes of fracture. The ore body is considered to be an epigenetic deposit.

The platinum metals occur both in the copper minerals and disseminated in the pyroxene and gabbro. The form in which these metals exist is not known, but probably they are not native alloys. This is generally true in deposits of this type, as seen in Sudbury, Canada. At the time of the writer's visit, the smelter had informed the owners of the property that platinum and palladium had a ratio of $1: 50$, and this was reported by the writer in his description of the property. Subsequent developments, however, contradict this statement. Thus, Brooks (1922, p. 23) gives the production of platinum from Alaska in the years 1917-20, practically all of which came from the Salt Chuck mine, and the average value per troy ounce of this output was $\$ 115.63$. Smith $(1929$, p. 39) quotes the Department of Commerce to the effect that 3,566 troy ounces was produced at this property in 1926, with an average value of $\$ 76.82$. Obviously these outputs could not represent a product that was 98 percent palladium, as this metal has for years been the cheapest of the platinum metals. The designation of the Salt Chuck mine as a palladium-copper mine is therefore incorrect, as it should be called a platinum-copper mine. Owing mainly to litigation, this property was closed at the end of 1926 and has not subsequently been reopened.

PLACERS GOODNEWS BAY DISTRICT

Mining and production

Platinum was discovered in 1926 at the mouth of Fox Gulch, a headwater tributary of Platinum Creek, by an Eskimo named Walter Smith. The sample, after passing through the hands of two other men, was sent to the U.S. Bureau of Mines, at Fairbanks, Alaska, where it was analyzed and determined to be platinum. In 1928, platinum was discovered in the gravels of Clara Creek, and in the same year it was discovered on Squirrel Creek. Details regarding these discoveries have been published by Irving Reed in Alaska, Supervisory Mining Engineer, (1933, p. 103-126). Eventually the Goodnews Bay Mining Co. acquired title to most of the productive ground on Salmon River and its tributaries and since 1940 has been the sole operating company.

A sketch map of the placer mining claims was published by the writer (Mertie, 1940b) ; but resurveys, the consolidation of some claims, and new locations have rendered this map obsolete. A new claim map is therefore included in this report (fig. 8). Unlike the original map, the names of the bench claims are not given, except for those to which reference is made in the text.

The Clara Creek Mining Co., using a dragline excavator, began mining on Clara Creek in 1936, and in the next 4 years worked out Clara and Dowry Creeks. This company also did some mining on Dry Gulch, a northern tributary of Platinum Creek. The Goodnews Bay Mining Co., likewise operating with a dragline excavator, began mining on Platinum Creek in 1934, and continued through 1941 until the placers of Platinum Creek, Fox Gulch, and Squirrel Creek were worked out. Thereafter this company, beginning on the association claim opposite 9 above Discovery, worked the bench placers of Salmon River for 11 years, ending this operation on the Bobby bench, opposite claim 3 above Discovery. From this point downstream, all mining was done by dredging.

A dredge was built by the Goodnews Bay Mining Co. in 1937 at the upper end of claim 1 below Discovery, Salmon River. This dredge worked upstream from its original site to claim 1 above Discovery, and turned working downstream to claim 7 below Discovery, where in 1942 it turned again and worked upstream to claim 5 above Discovery. Turning again in 1947, it worked downstream to claim 2 above Discovery, where in 1949 it moved eastward onto what is hereafter designated as the bench paystreak. Starting on the Ethel bench claim, the dredge worked sinuously but generally southward across the Palladium, Osmium, Ruthenium, Rhodium, Platinum and Iridium bench claims to Discovery claim, of Snow Gulch; and thence, from 1955 to 1963 , it worked southward to the Olson Bench claim. At this point the alluvial cover became too thick for economical dredging, even though 40 feet of the overburden was being removed by a dragline excavator; and therefore the dredge moved westward onto the paystreak of the valley floor of Salmon River. Starting on claim 10 below Discovery, the 


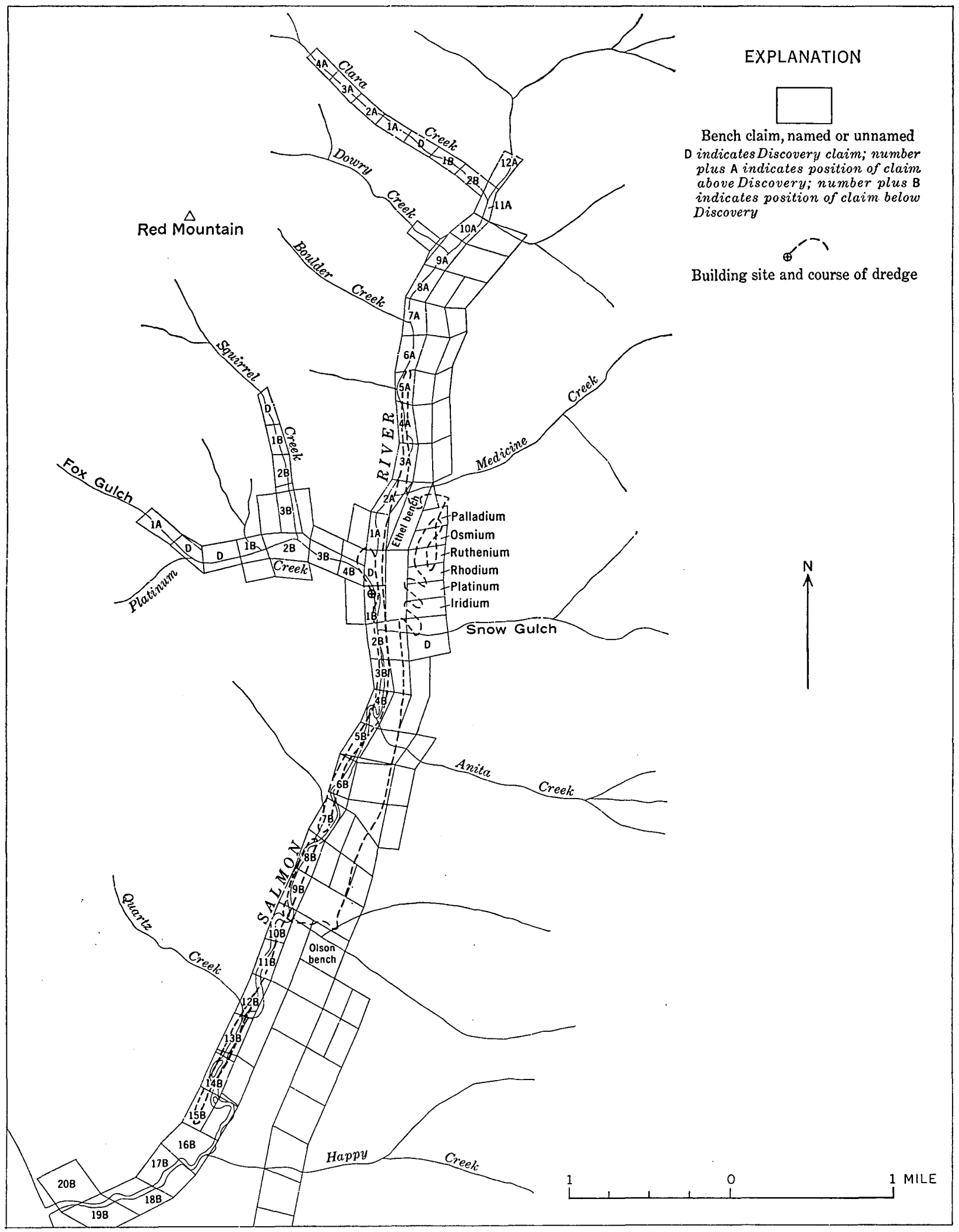

Frgure 8.-Location of principal mining claims on the Salmon River and its tributaries. 
dredge worked upstream to claim 8 below Discovery, where in 1964 it turned and began working downstream. In 1966, at the lower end of claim 15 below Discovery, the dredge again turned, and will continue to work upstream to claim 5 below Discovery. Thence it will move eastward onto the bench paystreak, and begin to rework tailings. Unworked ground also remains to be mined from claim 6 above Discovery to claim 11 above Discovery. The site where the dredge was built, and the course it has followed from 1937 to 1967 are shown in figure 8.

The bench paystreak continues south-southwestward for about 2 miles from the Olson bench claim, then veers southeastward toward Chagvan Bay. Much of this ground has been prospected by drilling, but the limits and tenor of the paystreak have not yet been precisely determined. It is known, however, that the depth of bedrock continues to increase, approaching 250 feet near Chagvan Bay. New methods ond equipment will be needed to mine this lower stretch of the bench paystreak. If the tenor will stand the cost, a belt conveyor may be used to dispose of a large part of the overburden.

The total production of platinum metals from Salmon River and its tributaries in the period 1934-66, including the output from Clara Creek, is estimated to have been well more than half a million troy ounces, with a maximum output in 1938 of 31,960 ounces.

Earlier and recent surveys

The general and economic geology of the Goodnews platinum district, a description of the placers, and a discussion of the character and composition of the platinum metals was published by the writer Mertie, (1940) in U.S. Geological Survey Bulletin 918, based upon a survey made in 1937. At the same time, a topographic map on a scale of 1:62,500 with 50-foot contours, was prepared by Gerald Fitz Gerald. In 1950, a new topographic map of a part of this district was made by the U.S. Coast and Geodetic Survey, on a scale of $1: 63,360$. This map, however, did not extend far enough north to show the settlement of Platinum, nor did it extend as far to the east as was needed. Accordingly, the original map by Fitz Gerald was enlarged to the scale of $1: 63,360$, and joined to the Coast Survey map, to produce the new map which is utilized in this report for charting the geology.

Much has been learned since 1937 regarding the distribution and character of these platinum metals by mining and exploratory drilling. To acquire the latest relevant information, the writer revisited this area in 1966 and again in 1968; and the owners of the Goodnews Bay Mining Co. cooperated by making available all their mining records since 1934 . A great deal of other information was obtained from the owners regarding the placers that bears directly upon the Pleistocene history of this district. Collateral data have also been obtained from the work of David Hopkins and other geologists of the U.S. Geological Survey, who have been studying submarine gold placers, offshore from Nome. Arthur F. Daily, a consulting mining engineer, has also supplied much pertinent geologic information.

\section{General geology}

The bedrock formations of the area, exclusive of intrusive rocks, comprise highly folded sedimentary rocks with some tuffaceous beds, overlain by lavas and tuffs, all of which are believed to be of late Paleozoic age. In late Mesozoic or Tertiary time these rocks were invaded by ultrabasic intrusives, and at a somewhat later date by granitic rocks. The ultrabasic rocks are of two general types, of which one is composed largely of olivine and the other of pyroxene with variable, but distinctly smaller, amounts of olivine. The olivine rock, or dunite, is the principal bedrock of Red Mountain, and about a quarter of it is altered to serpentinite. Olivine-bearing pyroxenite forms the ridge southwest of Susie Mountain. The granitic rocks occupy the long ridge southeast of the headwaters of Smalls River. The dunite and serpentinite are the bedrock sources of the platinum metals that are recovered from the placers of Salmon River and its tributaries. The granitic rocks are believed to be the sources of a small amount of gold that is also contained in the placers. The platinum metals have not been found in place, but much has been learned regarding their occurrence and character in bedrock, from the disposition and patterns of the areal drainage system, and from analyses of the platinum metals at many recorded sites in the valleys.

The Tertiary history of this region, from the time of the invasion by granitic rocks to the end of the Pliocene epoch, is obscure, but it seems probably that during most of this period the area was above sea level. Much more information, however, is available regarding the Quaternary period, though the regional geologic history during the Pleistocene epoch has proven to be a complex problem. In 1937, when the first geological survey of this area was made, all glaciation in western Alaska was referred to the Wisconsin Glaciation of the Pleistocene Epoch, and in the Goodnews Bay district, no consideration was given to 
the other glacial and interglacial stages that might have existed. This situation was changed in 1940, when a pre-Wisconsin Glaciation was recognized by the writer in the tin country of northwestern Seward Peninsula, and later that year was corroborated at Nome. This information was published in a paper by MacNeill, Mertie, and Pilsbry (1943, p. 69-96). Seward Peninsula and the Goodnews Bay district differ from the region south of the Alaskan Range in that the Wisconsin ice of southern Alaska extended to and beyond the Pacific strand line and regardless of whether an older glaciation had occurred, all traces of it have been obliterated, though its presence was recognized by Capps (1931, p. 1-8) north of the Alaskan Range. In western Alaska, however, the older glaciation was much more extensive than the Wisconsin ice, so that the evidence for its existence has been preserved.

Glaciations of Nebraskan, Illinoian, and Wisconsin age ${ }^{2}$ have now been recognized on Seward Peninsula, though evidence for a glaciation of Kansan time is still lacking. High mountains exist in the region east and northeast of Goodnews Bay, as in the central part of Seward Peninsula, and it seems probable that a similar Pleistocene history prevails in this district. In fact, at least three glacial stages seem necessary in order to explain the geochronology of the placer deposits. The Wisconsin ice, as at Nome, is believed not to have extended to the present strand line, but in any event, it appears to have had little or no effect upon the formation of the placers in the valley of the Salmon River. One of the earlier ice streams, however, possibly of Nebraskan age, was so extensive and thick that it overrode completely, or nearly so, the ridges on both sides of the Salmon River. But the course of that stream was athwart the flow of the ice, and this explains why the placers of that valley were not eroded and obliterated. The same, or more probably a later glacier of Illinoian(?) age, severed and destroyed a placer deposit in the lower valley of Salmon River, where it was not protected by bounding hills. Evidence for this overriding ice sheet consists of the presence of a small amount of free gold, not merely in the platinum placers of the Salmon River, but more particularly in the placers of Platinum Creek and of Fox Gulch, its headqater tributary. This gold, not derived from the ultrabasic rocks of Red Mountain, is believed to have been concentrated from glacial deposits derived from the overriding ice, which possibly was of Nebraskan(?) age. Another significant occurrence is the presence of granitic erratics at the northern

2 The names commonly applied to the glacial and interglacial stages of the Pleistocene Epoch are used in this report only to indicate chronologic sequence, and are not intended to imply close correlation end of Red Mountain, at a maximum altitude of 825 feet above sea level. These were probably deposited by Illinoian(?) ice, and show that, although this ice did not flow down the valley of the Salmon River, it must have deposited morainal and glaciofluvial materials at the head of that stream, which were moved downstream in that valley and were subsequently transported seaward.

Two paystreaks exist in the valley of the Salmon River. One of the significant features of both these alluvial deposits is that the underlying bedrock, at their lower ends, is far below present sea level. If this condition is related solely to eustatic changes in sea level, it follows that both these paystreaks were formed during glacial stages, when sea level was much lower than it is at the present time and glaciation was nonexistent in the main valley of the Salmon River.

This brief history of glaciation during the Pleistocene Epoch yields a geochronologic record that is patently incomplete; but the preceding statements of fact, with tentative interpretations, when coupled with the following descriptions of the two paystreaks in the valley of the Salmon River, will constitute an initial hypothesis which should lead eventually to a more complete understanding of the Quaternary history.

Deposits

Practically all the platinum metals so far found in this district occur in placers within the valley of the Salmon River and its western tributaries that head in the dunite of Red Mountain. Susie Creek, a small south-flowing tributary of Medicine Creek, that heads in the pyroxenitic rocks west of Susie Mountain, drains an area of ultrabasic rocks but contains no workable paystreak. The tributaries of the Salmon River that head in the Paleozoic sedimentary rocks and the overlying volcanic rocks are quite devoid of platinum. These include Quartz Creek, on the west side of the Salmon Valley, and Medicine Creek, Snow Gulch, Anita Creek, and Happy Creek on the east side.

This localization of the platinum metals in Red Mountain led naturally to a search for deposits of these metals along the west side of this mountain. No large streams are present, but a large volume of eluvial and alluvial deposits blanket its western slopes, and extends to Kuskokwim Bay. A large amount of drilling and manual prospecting has been done along this foreland, notably during the summer of 1937, when several drills were working; but virtually no platinum was found. Beach placers along the shore of Kuskokwim Bay are likewise absent, because the strand lines at the times when the paystreaks were being formed were far west of the present strand line. In 
later years, however, a little platinum was found and recovered from a small amphitheatrical opening in the southwest wall of Red Mountain, a short distance north of the low pass at the head of Platinum Creek.

Alluvial deposits of the platinum metals might also be expected to exist along the north side of Red Mountain, particularly because the dunite crops out along the north side of the Smalls River. But this stream has been deeply eroded by an Illinoian(?) glacier, which also scoured the northwest side of Red Mountain. However, a drill hole was sunk 192 feet to bedrock by the Goodnews Bay Mining Co. along the north side of the automobile road, about $11 / 2$ miles from Kuskokwim Bay, and reached platiniferous gravel. This platinum was apparently localized in a pothole that was not eroded by the glacier, as no continuation of the deposit was found.

Platinum Creek, with a length of about 2 miles, has two tributaries from the north, called Fox Gulch and Squirrel Creek. These streams had paystreaks which extended from their headwaters to their mouths; and Platinum Creek was minable from the mouth of Fox Gulch to its confluence with Salmon River. The paystreak on Platinum Creek included stream placers and others that would more properly be classed as bench placers, though the two types were not distinctly defined. At the mouth of Fox Gulch, the width of this paystreak was 200 feet, and at the confluence with Salmon River it had a width of at least 400 feet. The depth to bedrock, less the surficial cover of moss, ranged going downstream from 12 to 25 feet. The total length of the paystreaks of Platinum Creek, Fox Gulch, and Squirrel Creek, was about $31 / 2$ miles. The platinum metals occurred in the lower few feet of the gravels, and on the surface of bedrock, and for a few feet within the cracks and crevices of fractured bedrock. These metals consist of fine grains, which, however, are larger than those recovered from the paystreaks of Salmon River. Nuggets are uncommon, though more prevalent in Fox Gulch than elsewhere. The largest nugget so far recovered had a weight of 4 troy ounces.

The platinum deposits in the valley of the Salmon River occur in two distinct paystreaks, one in the present valley floor and the other in what has been designated as the bench channel, along the eastern side of the valley. The valley paystreak extends from claim 7 above Discovery, near the mouth of Boulder Creek, downstream to the lower end of claim 15 below Discovery, a distance of about 6 miles. This deposit ranges in width from 300 to 450 feet, except at the mouth of Platinum Creek, where it was as wide as 600 feet. The bench paystreak, as defined by drilling, extends from the association claim east of claim 9 above Discovery downstream to within three-quarters of a mile from Chagvan Bay, a distance of about 10 miles. On the Olson bench claim, this deposit had a width of 600 feet, but at some sites farther upstream it was as wide as 1,000 feet.

The bench paystreak presents numerous problems of genesis and age. The average bedrock gradient is about 15 feet per mile greater than the bedrock gradient of the valley floor, so that the thickness of the bench deposit increases more rapidly than that of the valley floor. Thus, at the northern limit of the bench paystreak, the depth to bedrock was found to be only 15 feet; east of Discovery claim, the depth had increased to 45 feet; and at the lower end of the Olson bench claim, the depth had increased to 125 feet. At and opposite the upper part of claim 7 below Discovery, the altitudes of bedrock on the paystreaks of the bench and the valley floor are identical. The increasing thickness of overburden on the bench is a function of the higher gradient of bedrock, which in turn is related to the lower base level of erosion at the time when the bench paystreak was formed. Thus, bedrock attains the altitude of sea level about 4.8 miles from Chagvan Bay, whereas the bedrock of the valley floor attains the same altitude about half a mile farther downstream. At Happy Creek, the bedrock of the bench channel is 50 feet below sea level; and at a point seven-eighths of a mile from Chagvan Bay, a drill hole to bedrock has shown a depth of 200 feet below sea level. By projection, the depth at the north side of Chagvan Bay is about 250 feet below sea level. The counterpart of this profile is suggested by the cited drill hole on the north side of the road from Platinum to the Goodnews mining camp, about 11/2 miles from Bering Sea, where bedrock was reached at a depth of 192 feet. On the other hand, the depth to bedrock at the mouth of Salmon River is only about 100 feet below sea level. Throughout the lower half of the bench paystreak, a large dragline excavator was used ahead of the dredge, to remove a part of the overburden, as the dredge could dig only to a depth of 60 feet. At the Olson bench claim, however, mining was temporarily discontinued, pending the development of new methods for the excavation and disposal of the increasing thickness of overburden.

The bench paystreak consists largely of clay from top to bottom, with an average content of about 20 percent gravel, which, however, is irregularly distributed vertically. Little sand and silt are present. The gravels occur mainly as inlaid seams and lenses in the clay, though in places drilling has penetrated beds of gravel ranging in thickness from 25 to 70 feet. 
The pebbles and small cobbles that constitute the gravels are subangular to rounded, many are faceted, and the nonsiliceous ones are greatly decomposed. Many of the siliceous gravels occur as fragments that obviously represent broken parts of larger stones. Most of the gravels are coated with tightly adhering clay, similar to the cohesive semi-indurated interstitial clay; and in panning or mining, extensive scrubbing is required in order to loosen and disintegrate this clay, so that the included platinum metals may be made available for recovery. These alluvial materials, without doubt, were originally of glacial origin. It must also be recorded that although most of the alluvial materials in the Goodnews Bay district are free of permafrost, yet drilling on the lower (southern) end of the bench channel have revealed a number of frozen strata, some as thick as 20 feet.

The bedrock, if nonsiliceous, is deeply weathered, at places to a depth of 5 feet or more, so that in drilling it is often difficult to determine the upper surface of bedrock, particularly if it is directly overlain by clay. So soft is the bedrock that it can be shoveled and panned, and samples of mineral concentrates have been obtained by this procedures. The platinum metals occur mainly on the surface of bedrock and in the overlying 10 feet of clay and gravel; but if the bedrock has been shattered, platinum metals may also extend several feet into bedrock.

The fact that the surface of bedrock in the bench channel is nearly flat from side to side, with no incised channels, indicates continuous erosion at a nearly constant base level of erosion over a long period of time. This condition has made it possible for the ancient stream that occupied this channel to carve away the lower ends of the lateral spurs along its eastern side and thus expand the valley floor to its stated width. It is also of interest that the bench paystreak has been locally enriched in platinum metals at the sites of tributary gulches from the east that drained a still older paystreak higher on the valley wall. The sites of these ancient gulches, however, do not correspond exactly with the position of the gulches shown on the topographic map. These high-level deposits have been prospected, but have been found to be narrow, intermittent (due to erosion), and too low grade to be mined at a profit.

The platiniferous clay above bedrock is so cohesive that it does not disintegrate readily in the trommel screen of the dredge nor in the succeeding gigs and riffles, so that a serious loss in platinum metals has occurred in dredging. To test the magnitude of this loss, and to determine whether the bench gravels should be reworked, the Goodnews Bay Mining Co. built in 1966 an experimental rig, which they called a "mud-hog," to macerate this clay and its included and adhering gravels; and this operation yielded a profit in 1966 and 1967. In reworking the bench gravels, the dredge will have to be equipped with improved equipment for handling this kind of alluvial materials, either by crushing or washing them, or both.

The paystreak and channel in the present valley floor differ markedly from those of the bench. The paystreak is narrower, ranging from 300 to 450 feet, except at the mouth of Platinum Creek, where locally it is as wide as 600 feet. The overburden is shallower, ranging in thickness from 30 to 80 feet, and gravels constitute a larger part of the alluvium. The mean size of the gravels is also larger than those in the bench paystreak, ranging in size up to 2 feet or more in diameter. Clay, however, is entirely absent, with corresponding increments in the amounts of sand and silt. The cobbles and pebbles are fairly well rounded, but many of the larger gravels are subangular. Finally, the bedrock, which is quite unaltered by weathering, is not level, but instead shows deep gutters with a depth as great as 20 feet. The platinum metals occur mainly on bedrock, in the overlying 2 feet of gravels, and in the uppermost 2 feet of shattered bedrock. The sizes of the grains, diminishing downstream, range from 0.2 inch to less than 0.002 inch in diameter.

A significant feature of the creek paystreak is that it terminates, or at least becomes of noncommercial grade, at the lower end of claim 15 below Discovery. Equally significant is the fact that along the east bank of the Salmon River, just above the mouth of Happy Creek, there is an ancient deposit of fairly well sorted outwash gravels of glacial origin. Similar deposits are present in the sea cliffs, about a mile north of the mouth of the Salmon River. Clearly the paystreak from claim 15 below Discovery downstream was severed and eroded by an ancient glacier, probably of Illinoian age, that emerged from the valley of the Kinegnak River, riding high on the north wall of that valley, and crossing the valley of the Salmon River as it moved seaward. But the lower end of the bench paystreak, as earlier stated, appears not to have been similarly destroyed by glacial erosion. All the lithologic data indicate that the deposits of the bench channel are older than the basal gravels in the channel of the present valley, and it therefore seems probable that the bench paystreak was preserved because it rested on a bedrock floor much lower than that in the present valley. Intensive drilling is now in progress on the bench paystreak downstream from the Olson bench claim; and the preceding interpretation may be verified if the uppermost alluvium of the bench paystreak proves to be similar 
to the gravels above the mouth of Happy Creek, and in the cited sea cliffs. Otherwise, the bench paystreak, old as it is, will have to be regarded as younger than the basal gravels of the valley paystreak. Under such an alternative interpretation, these basal gravels would probably be of Pliocene age, with other corrections in the genesis and age of the upper gravels of the valley floor.

Geochronology

The Pleistocene chronology, on the basis of available facts and inferences, can at best be only tentative, though a wealth of data that are now being analyzed and digested may later supply some of the missing links. Deposits of glacial origin have been found on the sea floor of Bering Sea, a long distance offshore from Nome; and the thickest and most extensive ice sheet that has overridden this region in Pleistocene time is believed to have existed in the first or Nebraskan Glaciation of this epoch. In the early Pleistocene, a great ice sheet appears to have nearly or quite overridden the hills that bound both sides of the valley of the Salmon River. Conceivably such an ice sheet may have developed either in Nebraskan or Kansan time, or even in both. In the absence, however, of conflicting data, the following chronology is based upon the existence of a single overriding ice sheet of Nebraskan age. As a result of this glaciation, the valley of the Salmon River must have received a large volume of morainal and glaciofluvial debris, most of which has subsequently been removed by erosion, though a part of it has been preserved in the bench channel along the east side of the valley. This is proven by the fact that no such materials now exist among the gravels that constitute the valley floor. Moreover, as earlier explained, an overriding ice sheet is a necessary part of the geochronology, in order to explain the presence of alluvial gold with the platinum metals in the upper valley of Platinum Creek.

The base level of erosion, at the apex of glaciation during Nebraskan time, was a strand line far south and southwest of Chagvan Bay. The mean gradient of the bedrock floor of the bench channel, from the center of the Olson bench claim to the north shore of Chagvan Bay, is known to be about 52 feet to the mile, such that the surface of bedrock at Chagvan Bay is now about 250 feet below sea level. The Nebraskan ice, which in its waning stages deposited glacial debris in the valley of the Salmon River, had an unrestricted outlet to the sea south and southwest of the Salmon Valley, and therefore must have greatly lowered the ancient base level of erosion. Hence even in the waning stages of Nebraskan glaciation, the local base level of erosion was much lower than at the present time. Thus, in late Nebraskan and early Aftonian time, a considerable part of the glacial debris in the Salmon Valley was eroded, but in part was preserved locally in the eastern bench channel. And eventually, with a rising base level of erosion, the bench channel was filled by aggradation. As a result, the course of the stream that occupied this channel was gradually shifted westward, and finally was superposed on bedrock at approximately the position of the present stream channel. The Aftonian Interglaciation, with a duration of approximately 200,000 years, was amply long to produce this aggradation and superposition.

The advent of the Kansan Glaciation, with or without local alpine glaciation, resulted in a new lowering of the base level of erosion. With a superposed drainage pattern already established, a new stream channel was carved under the control of a base level at least 100 feet lower than at the present time. This estimate is based upon the depth to bedrock at the mouth of the Salmon River. Another result was that all the remaining glacial debris of Nebraskan age was completely removed from the valley of Salmon River, except that preserved in the bench channel. In late Kansas time, and during the Yarmouth Interglaciation, the new channel was progressively filled with newly eroded gravels, and a paystreak was developed which extended much farther south than the paystreak of the present valley floor. This Kansan-Yarmouth erosion and subsequent sedimentation had virtually no effect upon the pre-existing bench channel, partly because erosion was in a new channel, but also because the lowering of the base level of erosion was distinctly less than that which prevailed in Nebraskan time.

The Illinoian Glaciation produced two significant results. The base level of erosion was again lowered, possibly in an amount intermediate between that which existed during Nebraskan and Kansan times. But in addition, active glaciation resulted in the development of ice tongues which emerged from the valley of the Kinegnak River, and from the valleys of the Goodnews River and its tributaries. Neither of these glaciers, however, moved down or up that part of the Salmon Valley enclosed by hills. The Kinegnak glacier eroded and dispersed such gravels as it could reach in the lower valley of the Salmon River, and in so doing, as earlier explained, severed and destroyed the lower end of the Kansan-Yarmouth paystreak. The effect of this transverse glaciation upon the bench gravels of the Salmon River has not yet been established, but the pre-existing bench paystreak was not obliterated, probably owing to the greater depth of its 
underlying bedrock. The Illinoian ice from the valley of Goodnews River and its tributaries similarly extended into the upper valley of the Salmon River, and deposited morainal and outwash materials there, but did not move down that valley. Instead the ice was shunted seaward past the north side of the Red Mountain, leaving glacial erratics, however, on that mountain up to an altitude of 825 feet.

The glaciation during Illinoian time probably also caused another geomorphic result. At the height of this glaciation the Kinegnak and Goodnews glaciers may have completely blocked the valley of the Salmon River, thus producing an elongate lake, which not only prevented any appreciable run-off downstream (or upstream), but also impeded the transportation of fluvial sediments seaward. Erosion on the hills, however, did not cease, and the weathered debris was merely dumped into the lake, resulting in aggradation. Thus the lowering of the regional base level of erosion during Illinoian time was partly or wholly ineffective for the Salmon River. Even if a channel, continuous or intermittent, was maintained around the north end of the Kinegnak glacier, the result for the Salmon Valley would have been dominantly aggradation, rather than stream rejuvenation and the seaward movement of sediments.

The ensuing Sangamon Interglaciation, characterized by a rising base level of erosion, must have produced further aggradation in the valley of the Salmon River. Platinum metals continued to be added to the paystreaks of Platinum Creek and Salmon River, but a sluggish river did not serve to re-create the lower end of the Kansan-Yarmouth paystreak that had been severed by the Illinoian ice. Similar aggradation doubtless occurred in the valley of the Smalls River, producing a superposition of this stream onto the southern wall of its valley. The subsequent erosion by the Smalls River in Wisconsin time is believed to have produced the gorge that is now visible about $41 / 2$ miles from the mouth of this river.

Glaciation was prevalent in the Kigluaik and Bendeleben Mountains of Seward Peninsula, and in the Tikchik and Oklune Mountains northeast of Goodnews Bay during Wisconsin time. Moffit (1913) and Smith (1910), however, who mapped quadrangles at and east of Nome, believed that the Wisconsin ice did not extend to the present strand line of Bering Sea; and the same is probably true in the Goodnews Bay district. Therefore in so far as glacial erosion is concerned, the Wisconsin glaciers are believed to have been impotent in this district; but a pronounced lowering of the base level of erosion must have been highly effective in removing a large part of the sediments that had accumulated during Illinoian and Sangamon time. Platinum metals continued to be eroded from Red Mountain and deposited in the valley of Salmon River and its headwater tributaries from the west; but the paystreak, though doubtless enriched, was not extended downstream from the point of severance in Illinoian time. In other words, bedrock was not again uncovered, probably because all the energy of Salmon River was used in removing the accumulation of superincumbent sediments from the valley of the Salmon River.

The foregoing chronology has been formulated without recourse to faulting, which could have had an important effect upon the establishment of unrecognized changes in the base levels of erosion during the Pleistocene Epoch. Yet faulting, parallel to the coast, has been recognized in the search for submarine placers offshore from Nome. It follows that more geologic work is needed in the Goodnews Bay district, before all the known facts can be satisfactorily explained.

\section{Platinum metals and gold}

The occurrence of the platinum metals in the dunite of Red Mountain has been proven indirectly, though no platinum lodes have been discovered, and no samples of platinum-bearing bedrock have been found. Moreover, a composite of this dunite, taken from the south to the north end of Red Mountain, revealed by analysis no trace of the platinum metals. It should be emphasized, however, that the content of platinum metals in such a sample was probably too low to be detected by ordinary chemical analysis. If the sample had been milled and panned, an analysis of the resulting concentrates might have shown the presence of platinum. In this connection, it should be recorded that the residual material at one site on top of Red Mountain was sampled and concentrated in 1965 by the Goodnews Bay Mining Co. and was found to contain a small amount of the platinum metals.

The platinum metals of the placers occur essentially in two distinct alloys intergrown in a pseudoeutectic fabric, which in nuggets is clearly visible under a lowpowered lens. These alloys do not have constant compositions nor do they have definite ratios to one another, and therefore they are not individually or collectively homogeneous. Moreover, the metals recovered from the placers, because they have been intermingled by stream transportation and fortuitous deposition, represent mixtures from many sites in the original lodes. Chemical analyses, however, of the metals recovered from the headwaters of the streams that drain Red Mountain, where maximum mixing 
had not yet occurred, reveal certain general characteristics of the lodes. Moreover, these analyses, when charted by claims, reveal also significant data that have a bearing upon the regional physiographic history, and lead to an understanding of the sequential history of the two paystreaks in the valley of Salmon River.

The platinum metals at the south end of Red Mountain are distinctly higher in iridium and osmium than at the north end, as shown by numerous chemical analyses of these metals in the streams draining this mountain. Thus, the mean tenor of iridium and osmium on Fox Gulch, and on Platinum Creek downstream to the mouth of Squirrel Creek, are respectively 27.85 and 5.24 percents; on Squirrel Creek, the corresponding values are 15.49 and 3.93 percents; on Dowry Creek, these values are 7.49 and 1.49 percents; and on Clara Creek, they are 6.17 and 0.93 percents. No analyses of the platinum metals from Boulder Creek are available, and it is therefore impossible to state whether the change in composition from Platinum Creek to Clara Creek is or is not linear in relation to distance. It should also be mentioned that the maximum values of iridium and osmium found on Fox Gulch were respectively 41.06 and 8.41 percents. Yet this product fails to qualify as osmiridium, because of the high tenor in platinum, namely 47.20 percent. In reality, this and all other platinum metals found in this district represent intergrowths in various proportions of the ordinary platinum alloy and osmiridium. The product from Fox Gulch merely has the highest ratio of osmiridium to the more common alloy.

The physical properties of the two alloys doubtless differ materially, but these cannot be determined, because pure samples of these alloys cannot be obtained. The magnetic properties, however, are quite evident in bulk samples from the placers. Thus, 4 percent of a sample from Salmon River was found to be ferromagnetic, whereas 25 percent of a sample from Clara Creek was found to be ferromagnetic. This difference is doubtless related to the change in composition of the platinum metals, from the south to the north end of Red Mountain. That is, the ratio of the major to the minor alloy probably increases in this interval. All these platinum metals, however, are paramagnetic, though in varying degrees.

The compositions of the two alloys that contain the platinum metals have not been specifically determined, first because they are variable and second because, for reasons heretofore cited, it is impossible to obtain a pure sample of either alloy. Approximately, however, the minor alloy (osmiridium) may be separated electro- magnetically, if grains of very small size are utilized in the separation. A sample weighing 365.53 grams, that represented platinum recovered in 1945 from Discovery claim, Salmon River, was used for this investigation. This was separated by sieving into 14 fractions; but unfortunately insufficient material of -200 mesh was available for a chemical analysis of that part of the sample with the smallest paramagnetism. One of the 14 fractions of larger size weighing 90.95 grams was therefore selected, and this was separated electromagnetically into seven subfractions. One of these subfractions, weighing 8.13 grams, with the least paramagnetism, was analyzed chemically, with separate analyses of the parts soluble and insoluble in aqua regia. Thus three analyses were obtained, as follows:

$T$. Composition of entire sample of 8.13 grams, wherein the ratio of the soluble to the insoluble fraction, $\frac{S}{I}=0.0375$.

$S$. Composition of that part of $T$ soluble in aqua regia.

I. Composition of that part of $T$ insoluble in aqua regia.

The selectivity of the separation is emphasized by the fact that the $\frac{S}{I}$ ratio of the original sample of 90.95 grams is 5.99 , whereas this ratio for the subfraction $T$ is only 0.0375 . The three analyses are shown in table 34.

TABLE 34.-Compositions, in percent, of electromagnetically separated alloy, and of its soluble and insoluble fractions, Goodnews Bay district

\begin{tabular}{|c|c|c|c|}
\hline & $T$ & $s$ & $I$ \\
\hline $\begin{array}{l}\text { Platinum } \\
\text { Iridium } \\
\text { Osmium } \\
\text { Ruthenium } \\
\text { Rhodium }\end{array}$ & $\begin{aligned} 14.48 \\
71.22 \\
11.00 \\
1.15 \\
2.15\end{aligned}$ & $\begin{array}{r}93.50 \\
5.78 \\
.00 \\
.00 \\
.72\end{array}$ & $\begin{aligned} \text { 11. } 52 \\
\text { 73. } 67 \\
11.42 \\
\text { 1. } 19 \\
\text { 2. } 20\end{aligned}$ \\
\hline & 100.00 & 100.00 & 100.00 \\
\hline
\end{tabular}

Sample $T$ appears to be mainly osmiridium, and the absence of palladium is therefore to be expected, as this is generally true of osmiridium in other parts of the world. A small amount of the major alloy, however, is believed to be present in the sample. The osmium and ruthenium are insoluble in aqua regia, as shown by analyses $S$ and $I$; but parts of the platinum, iridium, and rhodium are soluble. Reduced to grams, the $\frac{S}{I}$ ratios of platinum, iridium, and rhodium are found to be respectively $0.31,0.0035$, and 0.0046 . Thus most of the iridium and rhodium in sample $T$ is insoluble, whereas a third of the platinum is soluble. The $\frac{S}{I}$ ratio 
is about 9.60, yet for the original sample of 90.95 grams, this ratio is about 11.89 . Giving to these facts the most probable interpretation, it follows that analysis $I$ approaches closely to the composition of the minor alloy (osmiridium), but the exact composition is not ascertainable. Parenthetically, these data illustrate how the solubilities of the platinum metals vary, depending upon whether they occur in alloys, or whether the pure metals are tested. They also show the difficulties that arise in attempting to obtain the true compositions of either or both alloys, even in a single sample.

A small amount of free gold is recovered with the platinum metals of the placers. The exact source of this is unknown, but it is thought to have originated in quartz veins associated with the granitic rocks at the head of the Smalls River. The proximate source of most of the gold are twofold. An early Pleistocene glacier, probably of Nebraskan age, overrode the valley of the Salmon River. It moved westward and deposited a large volume of glacial debris in this valley. Later, a glacier believed to have been of Illinoian age, moved down the valley of the Goodnews River, and spread out into the valleys of Tundra Creek and the Smalls River. Thus morainal and glaciofluvial materials were dumped at the head of the Salmon River, whence they later were moved down that valley by running water.

The gold in the valley of the Salmon River was derived both from the Nebraskan and the Illinoian glacial deposits. In the paystreak of the valley floor the amount ranges from 0.70 to 4.78 percent, with a mean value of 2.36 percent. In the bench paystreak, the amount is appreciably less, ranging from 0.57 to 4.79 percent, with a mean value of 1.35 percent. In the headwaters of Platinum Creek, notably on Fox Gulch, the amount of gold is very small, ranging from zero to 0.37 percent, with a mean value of 0.1 percent. It is believed that this gold was derived from a thin sheet of glacial or glaciofluvial debris that was deposited in this area by the overriding Nebraskan glacier.

The dross of platinum metals is rarely determined, as it is generally included with the residual black sand under the heading of "impurities." Actually such impurities include the alloyed dross of the platinum metals, a minor amount of silver and dross in the gold, extraneous metallic impurities such as solder and lead shot that have not been removed, minerals adhering to or included in the platinum metals, and black sand that was impracticable to remove from the final product. The dross of native gold, which generally is copper and iron, constitutes about 1 percent of the gold-silver alloy. The dross of the major platinum alloy is believed generally to consist of 8 to 10 percent of iron, copper, and nickel, rarely cobalt. Chromium, if it shows in an analysis, is probably not an alloyed metal, but comes from included chromite. Under the microscope, a few minute included crystals of chalcopyrite have been identified in the Goodnews product, so that even the copper and iron of the analysis of a picked sample may not be entirely alloyed metals, though they dominantly are such. The dross of the osmiridium in the Goodnews Bay placers has not been determined, but like that from the Urals and Colombia, probably consists of iron and copper, though in much smaller amounts than in the major alloy.

Some data on the character and amount of the true dross of these platinum metals were earlier published (Mertie, 1940, p. 80-81). These are given in table 35 as analyses $A$ and B. In addition, Charles J. Johnston, of the Goodnews Bay Mining Co., later authorized Johnson, Matthey and Co., to make two complete analyses of platinum metals entirely free of black sand, from the Goodnews Bay district. These comprise analyses $\mathrm{C}$ and $\mathrm{D}$. These four analyses, recomputed free of all constitutents other than the platinum metals and dross, are shown in the table 35. The dross shown in these analyses is the dross of mixed platinum and osmiridium, which is somewhat less than that of the major alloy, but much greater than that of the osmiridium alone.

\begin{tabular}{|c|c|c|c|c|c|}
\hline & $\mathbf{A}$ & B & $\mathrm{C}$ & D & Mean \\
\hline latinum. & 57.84 & 82.25 & 77.07 & 77. 09 & 73.56 \\
\hline$n$ & 26. 15 & 5. 37 & 10. & 10.54 & 13. 16 \\
\hline 8 & 5. 71 & .54 & 1. 95 & 2. 03 & 2. 56 \\
\hline Ruthenium_- & .39 & .28 & .16 & .16 & .2 \\
\hline $\mathrm{um}_{-\ldots}$ & 1. 52 & 1.45 & .94 & .94 & 1. 21 \\
\hline ium. & .21 & .14 & .33 & .35 & .26 \\
\hline Iro & 7.51 & 9.48 & 8. 54 & 8. 48 & 8. 50 \\
\hline Copper.- & .40 & .37 & .43 & .41 & .40 \\
\hline Nickel_... & .27 & .09 & Tr. & Tr. & .09 \\
\hline Cobalt & & .03 & $\ldots \ldots$ & $\ldots$ & .01 \\
\hline Total & 100.00 & 100.00 & 100. 00 & 100.00 & 100.00 \\
\hline
\end{tabular}

A. Fox Gulch, Discovery claim. (Mentec, 1940, p. 80, 81). B. Clara Creek. (Mentee, $1940, p .80-81$ ).
and Dact localities unknown, but believed to be from Salmon River. Analyses
by Johnson, Matthey and C 0 .

A large volume of heavy minerals is recovered with the platinum metals. For example, a cleanup at one locality in the upper valley of Platinum Creek yielded 250 ounces of platinum metals together with 2 tons of concentrates, which were mainly magnetite, ilmenite, and chromite. The concentrates are classified, and the platinum metals are separated on a Wilfley concentrating table. The finest of this material still contains platinum and is ground and further concentrated. The platinum metals are finally cleaned by an ingenious vibrating blower. The final product that is sent to the refiner contains about 11 percent of impurities, of 
which perhaps 8 to 10 percent is alloyed dross, showing that the removal of black sand by the Goodnews Bay Mining Co. is nearly complete.

One outstanding feature is the large amount of chromite recovered in the sluiceboxes during the placer mining. Nuggets have been found in which chromite is attached to or intergrown with the platinum metals; and these, together with the large volume of chromite recovered in the placer concentrates, led to the belief that many of the platinum metals are associated in bedrock with chromite. A similar condition exists in the Ural Mountains of Russia. In the largest body of dunite in the Urals, in the Nishniy-Tagil district, about 600 lenses and irregular masses of chromite have been found, some of which contained notable amounts of platinum, as heretofore described. A part of the platinum metals in the Goodnews Bay district, however, may be sparsely and widely distributed in bedrock. The mean tenor of platinum metals in the dunite of Red Mountain may be computed by comparing what was probably the original volume of that mountain with the total platinum metals so far recovered and recoverable in the future, plus the metals lost in mining operation. Such a computation yields a mean value of about 0.13 grain per cubic yard, which might have a value of about 3 cents per cubic yard. Obviously, only local concentrations of platinum in chromite, such as that in the Krutoy Log property in the Urals, are likely to be of economic interest.

Chemical analyses

Every cleanup of the dragline excavators and dredge of the Goodnews Bay Mining Co., since 1934, has been graded by sieving into eight fractions, ranging in size from plus 8 to minus 48 mesh; thereafter the output from each cleanup was sent to the refiner (Johnson, Matthey and Co., Inc.) at Malvern, Pa., though duplicate chemical analyses have also been made by the Griffith, Ledoux, and Baker companies. The sieving analyses since 1943, and all the chemical analyses since 1934, have been made available to the writer by the Goodnews Bay Mining Co. A few analyses of the product from Clara Creek, made by the Wildberg Smelting and Refining Co., were obtained from the Clara Creek Mining Co. The data obtained from the Goodnews Bay Mining Co. comprise 643 sieving analyses and 977 chemical analyses.

A second source of information needs to be mentioned. From the 25th cleanup of 1945, the writer obtained from Charles J. Johnston, treasurer of the Goodnews Bay Mining Co., a sample of 365.53 grams, that included 321.84 grams of platinum metals, a little gold, and about 10.75 percent dross. This sample was taken to Malvern, Pa., where it was opened and sieved in the presence of John Cochrane, then chief chemist, but now a vice president of the American branch of Johnson, Matthey and Co., Inc. The sample was divided by sieving into 14 fractions, and the largest of these was subsequently subdivided into seven other fractions, which were separated from one another electromagnetically. Under the supervision of Mr. Cochrane, these 20 fractions were separated into dual subfractions, soluble and insoluble in aqua regia, and 40 complete analyses were made by E. R. Johnson, a chemist in the employ of Johnson, Matthey and Co., Inc. The expense of this work was born jointly by the Goodnews Bay Mining Co. and by Johnson, Matthey and Co., to both of whom the writer is greatly indebted. The three analyses shown in table 34 are based upon a part of these results.

A third source of information has been annual statements since 1934 by Charles J. Johnston, treasurer of the Goodnews Bay Mining Co., of the yearly production of the six platinum metals and gold, together with the weights of dross and other impurities as determined by chemical analyses. From 31 of these statements, omitting those of 1934 and 1935 of doubtful accuracy, it has been possible to construct two tables, 36 and 37, wherein are given, respectively, the annual percentages of the platinum metals, gold and impurities, and of the platinum metals free of gold and impurities.

TABLE 36.-Percentages of platinum metals, gold, and impurities, Goodnews Bay district

[Based on data from Goodnews Bay Mining Co.

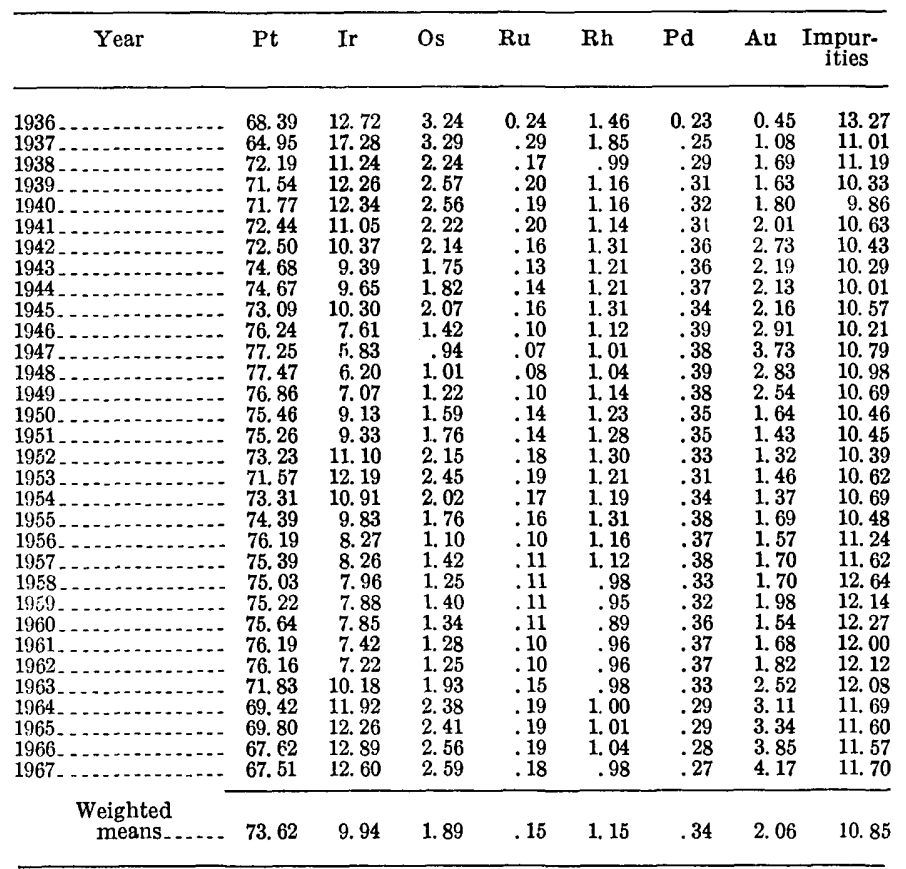


$\mathrm{T}_{\mathrm{ABLE}}$ 37.-Percentages of platinum metals, Goodnews Bay [Based on data from Goodnews Bay Mining Co.]

\begin{tabular}{|c|c|c|c|c|c|c|}
\hline Year & $\mathbf{P t}$ & Ir & Os & $\mathrm{Ru}$ & $\mathbf{R h}$ & $\mathrm{Pd}$ \\
\hline $\begin{array}{l}1936 \\
1937 \\
1938 \\
1939 \\
1940 \\
1942 \\
1943 \\
1944 \\
1945 \\
1946 \\
1947 \\
1948 \\
1949 \\
1950 \\
1951 \\
1952 \\
1953 \\
1954 \\
1955 \\
1956 \\
1957 \\
1958 \\
1959 \\
1960 \\
1961 \\
1962 \\
1963 \\
1964 \\
1965 \\
1966\end{array}$ & $\begin{array}{l}\text { 79. } 26 \\
73.88 \\
82.86 \\
81.25 \\
81.25 \\
82.92 \\
83.48 \\
\text { 85. } 33 \\
84.99 \\
83.75 \\
87.76 \\
90.38 \\
89.89 \\
88.58 \\
85.85 \\
85.40 \\
82.94 \\
81.40 \\
83.36 \\
84.70 \\
87.39 \\
86.97 \\
87.59 \\
87.59 \\
87.77 \\
88.27 \\
88.49 \\
84.11 \\
81.47 \\
81.00 \\
79.94 \\
80.25\end{array}$ & $\begin{array}{r}\text { 14. } 74 \\
19.66 \\
12.91 \\
13.93 \\
\text { 13. } 97 \\
\text { 12. } 65 \\
11.94 \\
10.73 \\
\text { 10. } 98 \\
\text { 11. } 80 \\
8.76 \\
6.82 \\
7.19 \\
8.14 \\
10.39 \\
10.59 \\
12.57 \\
13.87 \\
12.40 \\
11.19 \\
9.48 \\
9.53 \\
9.29 \\
9.17 \\
9.11 \\
8.59 \\
8.39 \\
11.92 \\
13.99 \\
14.41 \\
15.24 \\
14.98\end{array}$ & $\begin{array}{l}3.76 \\
3.74 \\
2.57 \\
2.92 \\
2.89 \\
2.54 \\
2.46 \\
2.00 \\
2.07 \\
2.37 \\
1.63 \\
1.09 \\
1.17 \\
1.40 \\
1.80 \\
2.00 \\
2.43 \\
2.78 \\
2.30 \\
2.00 \\
1.26 \\
1.64 \\
1.46 \\
1.63 \\
1.55 \\
1.48 \\
1.45 \\
2.26 \\
2.79 \\
2.83 \\
3.03 \\
3.08\end{array}$ & $\begin{array}{l}0.28 \\
.33 \\
.19 \\
.23 \\
.22 \\
.22 \\
.19 \\
.15 \\
.16 \\
.19 \\
.12 \\
.08 \\
.09 \\
.12 \\
.16 \\
.16 \\
.21 \\
.21 \\
.20 \\
.18 \\
.11 \\
.13 \\
.12 \\
.12 \\
.12 \\
.12 \\
.12 \\
.17 \\
.22 \\
.23 \\
.23 \\
.21\end{array}$ & $\begin{array}{l}1.69 \\
2.11 \\
1.13 \\
1.31 \\
1.31 \\
1.31 \\
1.51 \\
1.38 \\
1.38 \\
1.50 \\
1.28 \\
1.18 \\
1.20 \\
1.32 \\
1.40 \\
1.46 \\
1.47 \\
1.38 \\
1.35 \\
1.50 \\
1.34 \\
1.29 \\
1.15 \\
1.11 \\
1.03 \\
1.11 \\
1.12 \\
1.15 \\
1.18 \\
1.19 \\
1.23 \\
1.16\end{array}$ & $\begin{array}{r}0.27 \\
.28 \\
.34 \\
.36 \\
.36 \\
.36 \\
.42 \\
.41 \\
.42 \\
.39 \\
.45 \\
.45 \\
.46 \\
.44 \\
.40 \\
.39 \\
.38 \\
.36 \\
.39 \\
.43 \\
.42 \\
.44 \\
.39 \\
.38 \\
.42 \\
.43 \\
.43 \\
.39 \\
.35 \\
.34 \\
.33 \\
.32\end{array}$ \\
\hline $\begin{array}{l}\text { Weighted } \\
\text { means }\end{array}$ & 84. 53 & 11. 42 & 2. 17 & .17 & 1. 32 & .39 \\
\hline
\end{tabular}

Table 36 shows the percentages of the platinum metals, gold, and all impurities. Silver that was reported in a few of these analyses is alloyed with gold, and in table 36 is included as a part of the dross. Table 37 shows the platinum metals alone, recomputed to total 100 percent. The means at the foot of each column in both tables have been computed, not from the annual percentages, (which would be improper), but from the actual weights of the metals produced and are therefore equivalent to weighted mean values. From no other platinum field in the world is it possible to state with precision the actual composition of the metals that characterize that particular field.

The analytical data cited in tables 36 and 37 yield a number of conclusions regarding the composition and distribution of the platinum metals and alloys in bedrock, and also interpretations of the genesis and chronology of the two paystreaks in the valley of the Salmon River. These data will not be analyzed exhaustively in this report, but one generalization bearing upon the composition of the platinum metals in these two paystreaks should be mentioned. The crux of all these problems is the variable ratio of iridium to platinum in the platinum alloys of the ultrabasic mass if that constitutes Red Mountain. As earlier stated, iridium is the most prevalent at the southern end of this mountain, and least so at its northern end. Consequently, if the analyses of the platinum metals are charted claim by claim in the valley of the Salmon River, it is found that iridium increases and platinum decreases in both paystreaks, from their upper ends downstream to the mouth of Platimum Creek. Downstream from Platinum Creek, the amount of iridium in the paystreak of the valley floor continues to increase, rising to $151 / 2$ percent of the total platinum metals on claim 11 below Discovery. Parenthetically, this value approaches the mean value of 18 percent that characterizes the placers of Platinum Creek, between the mouth of Squirrel Creek and the Salmon River. In the bench paystreak, however, after a marked increment at the mouth of Platinum Creek, the amount of iridium decreases downstream, diminishing finally to $81 / 2$ percent on the Olson bench claim. Inversely, the percentages of platinum in the two paystreaks change respectively to $791 / 2$ and 88 percent. In general, the percentages of osmium and ruthenium correlate closely with those of iridium.

The bench paystreak has obviously received more of the platinum metals that originated in that part of Red Mountain north of Squirrel and Platinum Creeks, and conversely, a major part of the platinum metals in the paystreak of the valley floor came from the southern end of Red Mountain, via Platinum Creek and its left limit tributaries. It is not entirely ciear, however, whether this condition is a result of peculiar physiographic processes, or whether it is a function primarily of time. If, as heretofore stated, the paystreak of the valley floor is of composite origin, it is more probable that the high-iridium content in this paystreak may be dominantly a function of time, though other contributing causes will also require examination and evaluation. The volume of platinum metals in each paystreak, and other information deductible from the cited data, may yield more definite conclusions.

\section{OTHER ALASKAN DEPOSITS}

Alluvial platinum metals have been found to be widely distributed in Alaska, and prior to the discovery of the placers of Goodnews Bay district, they had been identified in alluvial deposits at about 20 localities. All these occurrences consisted of small amounts of the platinum metals found in gold placers, and none of these deposits became significant producers of platinum. These occurrences have been described by Chapin (1919, p. 137-141), Harrington (1919, p. 339-351, p. 
369-400), Maddren (1919, p. 229-319), and Mertie (1919, p. 233-264; 1933, p. 134-135). The recognized localities are as follows:

\section{Central Alaska}

Granite Creek, Ruby district

Boob Creek, Tolstoi district

$$
\text { Southern Alaska }
$$

Kahiltna River, tributary Yentna River

Cache Creek, tributary Kahiltna River

Willow Creek, Cache Creek district

Poorman Creek, Cache Creek district

Long Creek, Cache Creek district

Slate Creek, Chistochina district

Miller Gulch, Chistochina district

Metal Creek, Kenai Peninsula

Lituya Bay, beach deposit

Kodiak Island, beach deposit

Southwestern Alaska

Arolic River, lower Kuskokwim area

Snow Gulch, tributary Arolic River, lower Kuskokwim area

Bear Creek, tributary Tuluksak River, lower Kuskokwim area

Butte Creek, tributary Faro Creek, tributary Arolic River, lower Kuskokwim area

Marshall district, several localities, lower Yukon area

Seward Peninsula

Dime Creek, Koyuk district

Bear Creek, Fairhaven district

Sweepstakes Creek, Fairhaven district

Cache Creek is an eastern tributary of the Kahiltna River, which flows to the Yentna River, of southern Alaska. Traces of gold and platinum were panned on the bars of Kahiltna River, but the valley of this stream had no placers. On Cache Creek, however, and on a number of its tributaries, workable placers were found. A dredge which operated on Cache Creek in 1917 and in subsequent years commonly recovered about a level teaspoonful of platinum with each cleanup, and this probably represents the maximum production from any one site. The writers estimated that the platinum metals constituted about 0.3 percent of the gold by weight. Small amounts of platinum metals were also found in the upper tributaries of the Tokichitna River which head against Cache Creek. All these streams are in an intensely glaciated part of Alaska so that the bedrock sources of the gold and platinum are unknown.

Dime Creek, on Seward Peninsula, was one of the better known localities where the platinum metals were found in gold placers. The tenor was estimated by Harrington at 1 ounce per $\$ 5,000$ in placer gold, which, when the price of gold was $\$ 20.67$ per fine ounce, amounted to about that found on Cache Creek. During the season of 1917, 35 ounces of platinum metals was produced on Dime Creek. Another small producer was Boob Creek, in the Tolstoi district, where 30 ounces was reported to have been sold, but not necessarily produced, in 1917. The valley of Dime Creek and the other tributaries of the Koyuk River were not overridden by Wisconsin ice, but the bedrock sources of the platinum metals have not been definitely recognized. The same is true for Boob Creek, and the placers of the Ruby district, though a type of bedrock has been recognized that could have supplied platinum metals.

The production of placer platinum overlaps in time the lode production from the Salt Chuck mine, in southeastern Alaska, and as the two kinds of production were combined in the statements of the Geological Survey after 1917, no satisfactory estimate of annual or total placer production can be given, though the recorded annual production began with $81 / 3$ ounces in 1916, and was reported by Brooks (1922, p. 23) to have been 53.4 ounces in 1917. The gold placers of Snow Gulch, Bear Creek, and Butte Creek were prospected and by the Goodnews Bay Mining Co., but the platinum that was recovered was added to that produced in the early years of mining in the Goodnews platinum placers.

Chemical analyses

Four analyses of the platinum metals of Alaska were made in the laboratory of the U.S. Geological Survey by R. C. Wells, and published by Harrington (1919a, b), Maddren (1919), and Mertie (1919). In addition, three superior analyses were made by Johnson, Matthey and $\mathrm{Co}$., at the request of the Goodnews Bay Mining Co., of the platinum metals from the Snow Gulch, Bear Creek, and Butte Creek. Ruthenium was not determined in the U.S. Geological Survey analyses, and a considerable part of the iridium was not separated from the osmium. These analyses, recomputed free of impurities to total 100 percent, are shown in table 38.

These analyses are highly variable in their contents of the six platinum metals. The combined contents of iridium and osmium in samples C, D, E, F, and G range from 17 to 47 percent, but samples $\mathrm{E}, \mathrm{F}$, and $G$ are much higher in ruthenium than any samples from the Goodnews Bay district. The analysis of sample $C$ bears some resemblance to the analyses of the samples from Fox Gulch, in the Goodnews Bay district. Analysis A appears to represent a single platinum alloy, wherein the other elements are scantly represented. Analysis B may represent a major platinum alloy mixed or intergrown with a small amount of osmiridium, but the percentages are too indefinite to 
$\mathrm{T}_{\mathrm{ABLE}}$ 38.-Analyses in percent of Alaskan placer platinum metals [N.D., no data]

\begin{tabular}{|c|c|c|c|c|c|c|c|}
\hline & A & B & C & D & $\mathbf{E}$ & $\mathbf{F}$ & $G$ \\
\hline $\begin{array}{l}\text { Platinum } \\
\text { Iridium } \\
\text { Iridium plus osmium }\end{array}$ & $\begin{array}{r}98.1 \\
.5 \\
.7\end{array}$ & $\begin{array}{r}88.8 \\
4.7 \\
4.3\end{array}$ & $\begin{array}{l}51.4 \\
12.3 \\
34.8\end{array}$ & $\begin{array}{l}64.8 \\
10.0 \\
24.2\end{array}$ & $\begin{array}{r}76.32 \\
8.34\end{array}$ & $\begin{array}{l}72.82 \\
15.58\end{array}$ & $\begin{array}{l}59.07 \\
15.38\end{array}$ \\
\hline $\begin{array}{l}\text { Osmium } \\
\text { Ruthenium } \\
\text { Rhodium } \\
\text { Palladium. }\end{array}$ & $\begin{array}{r}. \mathrm{D} . \\
.4 \\
.3\end{array}$ & $\begin{array}{l}\text { N.D. } \\
\quad 1.1 \\
\quad 1.1\end{array}$ & $\begin{array}{l}\text { N.D. } \\
\text { Tr. }\end{array}$ & $\begin{array}{r}\mathrm{N} . \mathrm{D} . \\
.9 \\
.1\end{array}$ & $\begin{array}{l}8.34 \\
5.05 \\
1.26 \\
.69\end{array}$ & $\begin{array}{r}8.17 \\
2.29 \\
.78 \\
.36\end{array}$ & $\begin{array}{r}14.82 \\
9.31 \\
.96 \\
.46\end{array}$ \\
\hline Total....... & 100.0 & 100.0 & 100.0 & 100.0 & 100.0 & 100.0 & 100.0 \\
\hline
\end{tabular}

A. Boob Creek, Tolstoi district, central Alaska. Analyst, R. C. Wells (Harrington,

B. Dime Creek, Seward Peninsula. Analyst, R. C. Wells (Harrington, 1919b, p. 396) C. Poorman Creek, tributary Peters Creek, Cache Creek district, southern Alaska. Analyst, R. C. Wells (Mentie, 1919, p. 258)

D. Canvas Poi

E. 316).

G. Butte Creek. Analysis, Johnson, Matthey and Co.

draw any certain conclusions. Analyses $\mathrm{C}$ to $\mathrm{G}$, inclusive, definitely represent mixtures or intergrowths of two alloys, one mainly platinum and the other osmiridium. For samples $\mathrm{E}$ to $\mathrm{G}$, inclusive, this conclusion is fortified by the relatively high percentages of ruthenium.

\section{PLATINIFEROUS PLACER GOLD}

A terrestrial formation of Tertiary age crops out south of the Yukon River in Alaska and extends from the international boundary N. $60^{\circ} \mathrm{W}$. for about 90 miles. East of the international boundary, these rocks extend into Canada for an undetermined distance. This belt ranges from a width of 2 miles or less at the boundary to as much as 13 miles in the valley of Seventymile River, south of Eagle. At its western limit, the belt thins considerably, and west of Thanksgiving Creek is overlapped by unconsolidated alluvial deposits of Pliocene and Pleistocene age.

A batholith of granitic rocks crops out south of the terrestrial belt at distances ranging from 4 to 15 miles; and from quartz veins and other sources related to the granitic rocks much native gold has been liberated by weathering and erosion. The granitic rocks and their lodes are believed to be of Mesozoic age but were bared to erosion in early Tertiary time, and the gold from the related lodes was transported northward by streams and deposited in beds which later were indurated to form parts of the terrestrial formation. This Tertiary formation thus became a proximate source of native gold, and many of the valleys of streams that flow northward from these rocks contain gold placers which exist both as terrace deposits and as younger deposits in the present valley floors. The principal streams whose valleys have gold placers derived from such sources are, named from east to west, American Creek, Wolf Creek, Mission and Excelsior Creeks, several south-flowing tributaries of the Seventymile River, a small stream called Fourth of July Creek that flows northward to the Yukon River, Washington Creek, Webber Creek, and Thanksgiving Creek. The regional and economic geology of the granitic rocks, the terrestrial formation, and the placers derived therefrom have been described by the writer (1937, p. 251-261, and 1942, p. 213-264) in two earlier publications.

None of the gold placers that originated in the manner above described contains the smallest trace of free platinum metals. Nevertheless, three samples of the placer gold were selected by the writer for complete analyses, with special reference to any content of alloyed platinum metals. This work was done in the laboratory of the U.S. Geological Survey by R. E. Stevens. The resulting analyses recomputed to total 100 percent, together with their localities, are shown in table 39.

$\mathrm{T}_{\mathrm{ABLE}}$ 39.-Analyses, in percent of placer gold, Yukon Valley, Alaska

\begin{tabular}{|c|c|c|c|c|}
\hline & 38 A Mt 27 & 38 A Mt 57 & $38 \mathrm{~A} \mathrm{Mt} 90 \mathrm{a}$ & Mean \\
\hline Gold & 81.13 & 88.23 & 93.17 & 87.51 \\
\hline Silver & 18. 33 & 11. 21 & 6. 19 & 11. 91 \\
\hline Platinum & .20 & .28 & .42 & .30 \\
\hline Iridium & .02 & .05 & $\mathrm{Tr}$ & .02 \\
\hline Rhodium_ & None & None & None & None \\
\hline Palladium_ & None & Tr. & None & Tr. \\
\hline Lead & .06 & 07 & .08 & .07 \\
\hline Mercury & 10 & .05 & .02 & .06 \\
\hline Iron & .08 & 07 & .07 & .07 \\
\hline Copper & .03 & 01 & 04 & .03 \\
\hline Zinc & .04 & .03 & .01 & $\therefore 03$ \\
\hline Cobalt_. & None & None & None & None \\
\hline Nickel & None & None & None & None \\
\hline Bismuth & None & None & None & None \\
\hline Tin & Tr. & Tr. & $\mathrm{Tr}$. & \\
\hline Total & 100.00 & 100.00 & 100.00 & 100.00 \\
\hline
\end{tabular}

38 A Mt 27. Seventymile River, at mouth of Broken Neck Creek. Analyst, R. E. 38 A Mt 57. Fourth of July Creek, 7 miles airline from mouth. Analyst, R. E. 3 A Mt 90a. Woodchopper Creek, 4 miles airline from mouth. Analyst, R. E. Stevens.

These analyses represent three grades of native gold, having finenesses respectively of 811,882 , and 932 . Sample 38 A Mt 90a, with gold of the highest grade, contained the largest amount of platinum metals. This highgrade gold was being mined in large volume in 1938 by a dredge, and the operators, when informed by the writer of the content of platinum metals in their product, tried to recover payment for the same. Payment, however, was refused, because the United States mint claimed the platinum metals as seignorage. Thereupon the operators took steps to recover the value of the platinum metals by having them separated from the gold before the latter was sold. This yielded an increment in gross profit of about 1.3 percent, from which, however, the cost of the pretreatment of the gold had to be deducted. 
This occurrence of platinum metals in native gold is not unique, as similar gold has been mentioned by others, but it probably is one of the best authenticated quantitatively. On page 98 of this report are described certain rare deposits of gold quartz veins which have also yielded small amounts of the platinum metals. It is also known that significant amounts of the platinum metals are recovered in the refining of gold and copper. From these considerations, it follows that the native gold containing small amounts of alloyed platinum metals may be more commonplace than is generally recognized.

\section{EXPLORATION IN ALASKA}

The platinum metals have been shown to exist at many widely separated sites in Alaska, and one workable lode and one important placer deposit have been developed. These occurrences should offer encouragement for a careful search throughout the State for new deposits. It is true that a great deal of prospecting has been done in Alaska, but this work has had for its principal objective the discovery of gold placers. Native platinum could readily be overlooked in panning streams for gold, as the ordinary prospector might not have been impressed by the presence of steely looking grains in his gold pan. This apparently was true in the Goodnews Bay district, as this area was well known and accessible to prospectors for at least 25 years before the initial discovery of platinum was made. Therefore, such earlier prospecting by men searching primarily for gold must be greatly discounted.

The search for platinum lodes, however, is a project that requires understanding of the difficulties involved and may be beyond the capabilities and resources of ordinary prospectors. Platinum-bearing lodes, such as those of Canada, South Africa, and Siberia, are generally deposits of sulfides of copper and nickel. Those sulfides, if not destroyed by weathering, could be recovered in concentrated form by panning alluvial deposits; and if they are thought to be platinum-bearing, may be submitted for analysis. On the other hand, if the sulfides have been destroyed by weathering, the liberated platinum minerals, because they are so fine grained, are likely to have been floated by water and to have been widely distributed far downstream. If the platinum metals are chemically combined with the sulfides, the scattering is still more diffuse. Hence, the gold pan has a limited adaptability in prospecting for platinum lodes.

Small samples of bedrock will not be useful for analysis, because the platinum metals are so sparsely and widely disseminated, both as native platinum and platinum minerals, that such analyses will be undependable.
Large samples of bedrock will be needed, and in a country like Alaska, these will have to be transported long distances to get them to a laboratory where they can be crushed, milled, and concentrated prior to analysis. Bearing in mind these obstacles and safeguards and the lack of cheap transportation throughout most of Alaska, it is not surprising that the search for platinum lodes in this State has so far been unsuccessful. Finally, analyses for the platinum metals should not be attempted by an ordinary assayer or chemist; in fact, assayers of excellent reputation have failed in such work. Instead, the samples should be submitted to processors of the platinum metals, or to others who are familiar with the chemical methods required. Superior analyses for the platinum metals are very expensive, and for this reason, the prospecting for platinum lodes will have to be done by mining companies with adequate financial backing.

Geologic maps on reconnaissance or exploratory scales are now available for most of Alaska, and more detailed maps are locally available. Ultrabasic and gabbroic rocks, the hostrocks of most of the platinum metals, will appear on these maps, and such rocks will serve as a first guide to concerns that are financially able to undertake prospecting for platinum metals. One example of an area that should be prospected is in the Yukon-Tanana region, of interior Alaska, where ultrabasic and basic rocks crop out intermittently for a distance of about 90 miles from the headwaters of Salcha River west-southwestward to the Tanana River, about 25 miles southeast of Fairbanks. Similar examples may be found in other parts of Alaska. Most of these projects will require the use of helicopters.

\section{CALIFORNIA}

Bodies of peridotite and serpentinite are present in California, and some of these have been cited as bedrock sources, though not all are well authenticated. One of these is in San Bernardino County where platinum was reported with lead carbonate at a mine near Cima. A second was the occurrence of platinum in chromite ore in Del Norte County. A third was the reported occurrence of platinum in serpentinite in the valley of Trinity River. A fourth was the reported discovery of traces of platinum in peridotite in the Santa Lucia Mountains in San Luis Obispo County.

\section{PLACERS}

Alluvial platinum has been found at numerous localities in California in association with native gold, and a small production has resulted as a byproduct of gold placer mining. Such mining has been done in two general districts. The largest and most productive of 
these, both in gold and platinum, is the piedmont district west of the Sierra Nevada Mountains, that extends from Plumas County south-southeast for about 210 miles to include Merced and Mariposa Counties, with a width ranging from 30 to 65 miles. Other scatterred localities lie farther to the west, south, and southeast. The second principal area is the Klamath district, which from the northwestern corner of the state extends south-southeast for about 170 miles to Tehama County, with a width of about 40 miles.

The 21 counties of these two areas are listed alphabetically below, and the 15 which have been productive are indicated by an asterisk.

\begin{tabular}{|c|c|}
\hline \multicolumn{2}{|c|}{ Platinum-bearing counties of the piedmont area } \\
\hline 1. *Amador & 9. Plumas \\
\hline 2. *Butte & 10. *Sacramento \\
\hline 3. *Calaveras & 11. San Joaquin \\
\hline 4. El Dorado & 12. Sierra \\
\hline 5. Mariposa & 13. *Stanislaus \\
\hline 6. *Merced & 14. Tuolumne \\
\hline 7. *Nevada & 15. *Yuba \\
\hline
\end{tabular}

The scattered localities west, south, and southeast of the Sierra district are in Inyo, Kern, Madera, Riverside, San Bernardino, and Yolo Counties. None of these has been productive.

Platinum-bearing counties of the Klamath district
1. *Del Norte
4. *Siskiyou
2. *Humboldt
5. *Tehama
3. *Shasta
6. ${ }^{*}$ Trinity

Platinum metals also occur along the Pacific beaches from Ventura County northward to and beyond the California-Oregon line. These counties containing littoral deposits, named from south to north, are as follows:
1. Ventura
2. Santa Barbara
3. San Luis Obispo
4. Monterey
5. Santa Cruz
6. San Mateo
7. Mendocino
8. Humboldt
9. Del Norte

Platinum has also been found inland from the beaches in San Luis Obispo and Mendocino Counties, and Mendocino County has been a producer from such a source.

\section{DEPOSITS}

Most of the platinum recovered in California has been and is being produced as a byproduct of gold placer mining in the piedmont and Klamath districts, though a small production came in earlier years from beach mining, particularly from Humboldt and Del
Norte Counties. The piedmont district, owing to its geographic environment, has been the largest and most consistent producer. The eastern tributaries and sub-tributaries of the Sacramento River head in the Sierra Nevada and debouch onto low foothills with broad valleys of low gradients that are especially adapted to dredging. Such sites of dredging, named from north to south, are the valleys of Feather River, Yuba River, lower and upper American River, Cosumnes River, Mokelumne River, Calaveras River, Stanislaus River, Tuolumne River, and Merced River.

The Feather River valley was the first site of largescale dredging in California, which was begun in the vicinity of Oroville. The paystreak was originally determined to have a length of 7 miles and an average width of over a mile, but this was probably extended in later days of mining. Drilling has shown no bedrock to a depth of 500 feet, so that the section includes 6 to 16 feet of soil, underlain by auriferous gravel with a thickness of 20 to 50 feet, underlain by grayish volcanic ash which functions as a false bedrock. Most of the precious metals occur low in the gravel, close to the layer of ash. The ratio of gold to platinum metals is reported to be about $1,000: 1$, and the ratio of platinum to osmiridium is given by Logan $(1919$, p. 21$)$ as approximately $10: 3$.

The valley of the Yuba River is similar in most respects to that of Feather River. The overburden varies in depth from 45 to 100 feet, and the pay gravel rests similarly on volcanic ash. The fact that platinum decreases more rapidly than gold in the downstream part of the paystreak indicates that the grains of platinum are probably larger. The ratio of gold to platinum metals ranges from $500: 1$ to $2,500: 1$. It is stated by Logan (1919, p. 21) that platinum constitutes 62 to 69 percent of the platinum metals and that the sum of iridium and osmium is 15 percent, of which iridium is much more plentiful than osmium. The conditions on the Feather and the Yuba Rivers are fairly typical of those in the valleys farther south, except for differences in stratigraphic sections, ratios of gold to platinum metals, and the composition of these metals.

The Klamath district differs from the Sierra Nevada district in that it consists largely of mountains, with streams of high gradients that flow in narnarrow valleys. The Klamath, Siskiyou, Trinity, and other coastal ranges make up the mountainous areas. Siskiyou, Trinity, and part of Humboldt Counties are drained by the Klamath River and its tributaries; Shasta and Tehama Counties lie within the watershed of the Sacramento River; and Del Norte County is drained by the Smith River and its several forks. The Klamath is a stream with many tributaries, of which the largest is the Trinity River; a smaller tributary, 
in which much placer mining was done, is the Salmon River, which enters about 20 miles upstream from the mouth of the Trinity River. Both stream and terrace deposits constitute the workable placers of the Klamath district, and owing to the topography, most of these have been worked by hydraulic methods. One of the well-known terrace deposits of the Smith River is French Hill, between its South and Middle Forks, at an altitude of 2,000 feet; but many stream and low terrace deposits have been worked in the tributaries of the Smith River.

Considerable gold placer mining was done at numerous sites in the valley of the Klamath River, and one dredge was operated on a southern tributary called Scott Creek. The principal mining, however, was done on the Trinity River and its tributaries, particularly upstream from its North Fork. In the headwaters of Trinity Creek is Hayforth Creek, which is well known as a producer of gold. The two headwater tributaries of Hayforth Creek head against Beegum Creek, a headwater stream of the Sacramento drainage system, which is a well-known producer of Tehama County. The valleys of the Trinity River and its tributaries have many terrace deposits at different altitudes, some of which have been highly productive; and its valley floor has important stream placers. At least two dredges and numerous hydraulic plants have worked the stream placers of the Trinity River. The upper valley of the Trinity River is well known for the presence of large nuggets of platinum, but unfortunately no precise chemical or mineralogical investigations of these nuggets were made.

Platinum has been found on the Pacific beaches of California intermittently from Ventura County northward to and beyond the California-Oregon line, but the principal mining operations have been in the vicinities of Gold Bluff, Big Lagoon, Stone Lagoon, and Little River, in Humboldt County; and near Crescent City, Gilbert Creek, and Smith River, in Del Norte County. Mining began at Gold Bluff in 1851 and continued at other sites during the fifties and sixties but was most active from the middle of the seventies until the deposits were exhausted. Most of these operations were along the present beach, but terrace deposits were also found farther inland, though these were generally of lower grade. Few data are available concerning the character of the platinum alloys but five analyses of the platinum metals from the beaches of Humboldt County are given in table 40 (analyses $1-5$ ). It also is recorded by Hornor (1918, p. 35-37) that the semiheavy minerals found near Crescent City consisted mainly of magnetite, ilmenite, chromite, garnet, monazite, olivine, apatite, picotite, rutile, and corundum.
The earliest production of placer platinum in California has not been recorded, but Quiring (1962, p. 254) cites an output of 656 crude ounces in 1880. According to Symons (1943, p. 49) the total production of platinum metals from 1887 to 1941 , inclusive, was 22,520 ounces, with a maximum output of 1,358 ounces in 1940, and a minimum output of 39 ounces in 1903. These figures represent crude ounces for the interval 1887-1918 and fine ounces for the interval 1919-41. Hence, the total output for the period 1887-1941 must be less, perhaps 1,000 to 1,500 ounces less, than the cited total. Moreover, a declining production of placer gold in California since the Second World War has further diminished the output of platinum metals. Considering all factors involved, it is believed that the total output to 1963 has not exceeded 30,000 ounces.

\section{CHEMICAL ANALYSES}

The placer mines of California are like those at other places in the world where platinum metals were or are being produced as a byproduct of gold mining. Little attention is given to the composition of these metals, and most of the analyses are rather crude commercial assays, of which some were made by nonqualified analysts. In such assays, iridium and osmium are rarely reported separately; and except in osmiridium, ruthenium is altogether ignored. One cause of this in the early days of mining was that osmium was not even bought, and hence was not reported. The available data thus constitute a problem in their presentation. If reported as given, the different analyses are hard to compare; but if recomputed to total 100 percent, it is certain that the tenors of the reported elements are unjustifiably increased by the distribution in them of the unreported elements. Neither method is correct, but the second seems to represent the lesser of two evils, and is used in table 40.

The localities of the available analyses, so far as they are known, are given in the table. Some analyses are given as averages. Others, such as $1-5$, are given individually; first, because the tenors in platinum are strongly variable, and second, in order to show tenors: in iron and copper, which are not generally available in the other analyses.

A considerable number of analyses of the platinum metals, more incomplete than the preceding ones, have also been published by Logan (1919, p. 109) (table. 41). These, however, have considerable value in that they show general variations in composition from: county to county.

The analyses (tables 40 and 41) show two characteristics possessed by the platinum metals of California. First, a great variation exists in the compositions of 
Table 40.-Analyses, in percent, of California placer platinum metals

[N.D., no data]

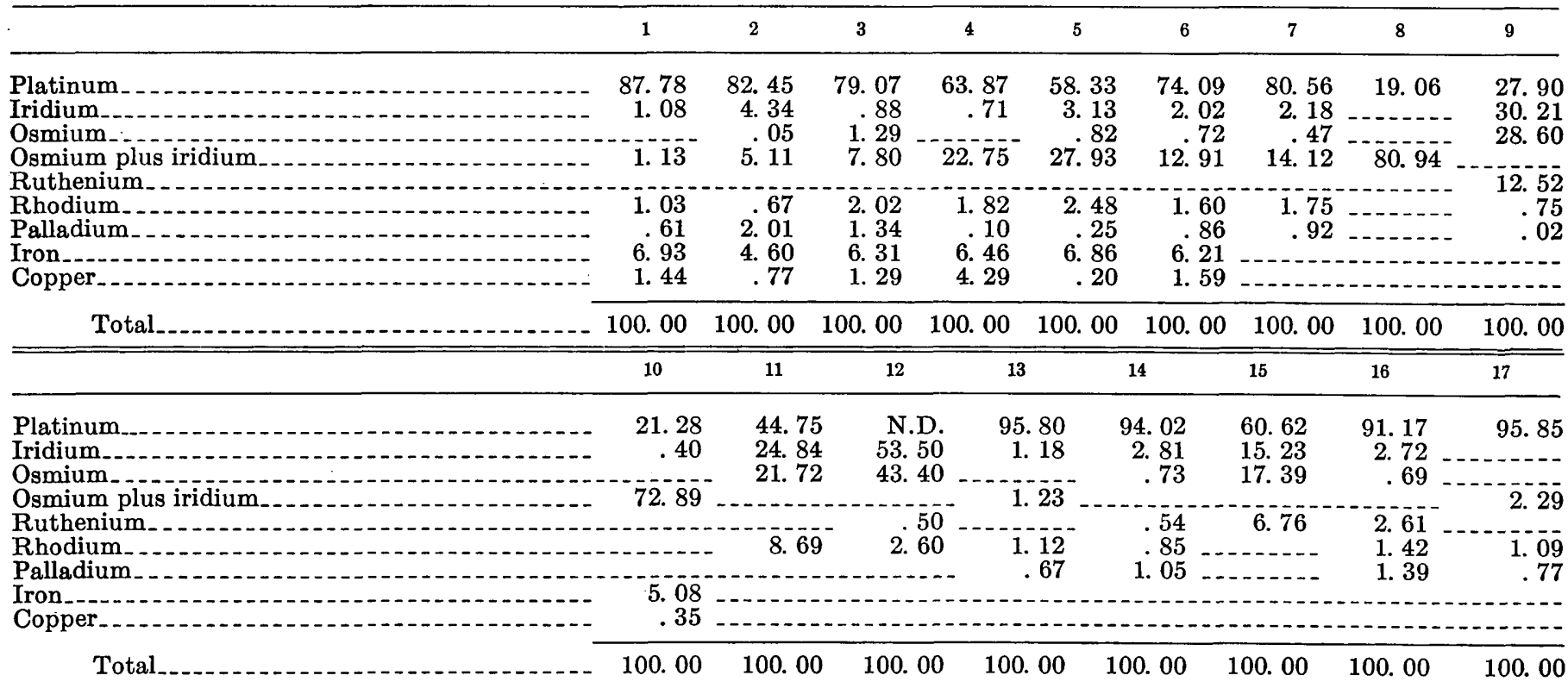

1-3. Deville and Debray (1859). Platinum in black sands of the Pacific Coast of California. 1862 ). Platinum from California (black sands)

4. Kromayer (1862). Platinum from California (1859, p. 262). Platinum ores from California.

6. Mean of analyses $1-5$.

7. Mean of analyses $1-5$, recomputed free of iron and copper.

8. Deville and Debray (1859). Native platinum from a placer deposit at China Flat,

Humbolt County.
9. Mean of 11 analyses of the platinum metals of Trinity County, given to the writer by C. C. Stearnes, a mining operator in that County. (Analyses by Wildberg Bros. Smelting and Refining Co. of San Francisco.)

TABLE 41.-Incomplete analyses, in percent, of California placer platinum metals

[Analyses from Logan (1919, p. 109) recomputed to total 100 percent]

\begin{tabular}{|c|c|c|c|}
\hline & & & $\mathrm{s}$ Ir \\
\hline $\begin{array}{l}\text { Bula } \\
\text { Del Norte }\end{array}$ & $\begin{array}{r}76.91 \\
65.32 \\
\text { 8. 8-12.1 } \\
26.13 \\
26.92 \\
10.43 \\
97.70 \\
63.87 \\
74.15 \\
71.09 \\
67.33 \\
62.25 \\
51.74 \\
35.37 \\
\text { 34. } 1-82.9 \\
2.95 \\
\text { 13. 8-20.5 } \\
47.63 \\
41.28 \\
80.84 \\
78.89 \\
81.77 \\
81.78 \\
80.83 \\
80.12 \\
80.42 \\
79.76 \\
80.31 \\
77.74\end{array}$ & $\begin{array}{r}23.09 \\
-51.97 \\
36.13 \\
25.85 \\
28.91 \\
32.67 \\
37.75 \\
48.26 \\
20.05 \\
\\
\\
\end{array}$ & \begin{tabular}{r}
34.68 \\
50.91 .2 \\
73.87 \\
73.08 \\
37.60 \\
2.30 \\
\hdashline $91 .-1$. \\
\hdashline $0-86.2$ \\
52.37 \\
58.72 \\
19.16 \\
21.11 \\
18.23 \\
18.22 \\
19.17 \\
19.88 \\
19.66 \\
20.24 \\
19.69 \\
22.26
\end{tabular} \\
\hline
\end{tabular}

10. Mean of 2 analyses. Deville and Debray (1859). Native platinum from the Trinity River.

11. Cosumnes River, Sacramento County. Collected by writer.

12. Deville and Debray (1859). Locality unknown.

13. Lindgren (1919, p. 790). Analysis quoted from Deville and Debray.

14. Merced River, Merced County. Collected by writer.

16. Trinity County. Collected by writer.

p. 22).
17. Miscellaneous analysis, county not known.

the samples. The first five samples of table 40 show that even in a single county, here it is Humboldt County, the tenor of platinum, recomputed free of iron and copper, ranges from 96 to 63 percent, whereas the tenors in iridium plus osmium, similarly recomputed free of iron and copper, range from 34 to 2 percent. But in table 41 the mean tenors of platinum and iridium plus osmium for samples 21 and 22 , also from Humboldt County, are respectively 27 and 73 percent. Hence, the overall ranges in platinum and iridium plus osmium for Humboldt County are respectively 96 to 27 percent and 73 to 2 percent. Over the whole California field, however, the maximum and minium tenors for platinum range from 98 to 3 percent and of iridium plus osmium from 90 to 2 percent. These values indicate the presence of two alloys, one consisting mainly of platinum and the other of osmiridium, generally mixed or intergrown in unknown proportions. A number of analyses, however, indicate the presence of one of these alloys mixed with little or none of the other. Thus, samples $1,13,14,16,17$, and 24 apparently represent alloys with little or no intergrown or intermixed osmiridium. Analysis 9 appears to represent osmiridium mixed with a minor amount of ordinary platinum. 
Analyses 12 and 33 represent osmiridium, from which the analyst recovered little or none of the ruthenium, which should be present.

The second characteristic of many of these analyses is the high tenor of iridium plus osmium, which indicates that where the two alloys are mixed or intergrown, osmiridium is an important component. Analysis 9, which represents 11 individual analyses and contains about 59 percent iridium plus osmium, illustrates this feature, as do also analyses $8,10,12$ (table 40) and 35 and 36 also from Trinity County (table 41). The inference may therefore be drawn that osmiridium is notably prevalent in Trinity County. The same inference, however, also applies to Del Norte, Humboldt, Siskiyou, and Tehama Counties, of the Klamath district. The lowest tenors in iridium plus osmium appear to be prevalent in Butte and Yuba counties, of the piedmont district, but even in these two counties, osmiridium is an important component.

\section{COLORADO}

The La Plata mining district is in La Plata and Montezuma Counties, in southwestern Colorado; the Copper Hill mine, with which this discussion is principally concerned, is about one-half a mile northwest of La Plata, in La Plata County. This district was described by Eckel and others (1949). The part of that report which deals with the platinum metals was written by G. M. Schwartz, D. J. Varnes, and E. B. Eckel.

The ore deposits of this district are classified mineralogically into five types, of which one is described as disseminated chalcopyrite with platinum and palladium. This type is exemplified by the Copper Hill mine, which apparently is a contact metamorphic deposit, in which Permian sediments were mineralized and replaced by silicates and ore minerals that originated in a bounding body of syenite. The principal ore minerals are chalcopyrite, hematite, magnetite, and pyrite, which are localized in closely spaced veinlets. Ore taken from the glory hole had a mean tenor of 4.79 percent copper, at least 17 ounces silver to the ton, and small amounts of gold and platinum metals. A tunnel driven directly under the glory hole showed no workable ore, and the rock bounding the glory hole is of distinctly lower grade. The mode of occurrence of the platinum metals was not established, though their tenors increased with that of the copper. Probably the platinum and palladium occurred as minute mineral intergrowths in the chalcopyrite. No assays are available of the platinum metals found in the glory hole, but adjacent to this 80 -foot excavation, the tenor of platinum metals was determined to be 0.005 ounce per ton. This deposit is obviously of no importance as a source of platinum metals.

\section{IDAHO}

Deposits of extremely fine grained gold and platinum occur along the Snake River across the entire southern part of Idaho, and along the west side of the State where Snake River forms the boundary between Idaho and Oregon. These deposits are to be classed as flour gold and platinum. They have been mined along the river bars and on benches, but most of this work was not profitable. The smallest grains have an average value of about 1 cent for 2,500 grains, but the value may be as low as 1 cent for 35,000 grains. Platinum metals are present but do not attain either the maximum or minimum sizes of the grains of gold. The ratio of gold to platinum is reported by Hite (1933) to be about 2,500:1. Most of the attempted mining was done upstream from the canyon of Snake River, but none of it was important.

\section{MONTANA}

STILIWATER COMPLEX

The Stillwater Complex is an elongate assemblage of intrusive rocks that occurs in Sweetwater County, Mont., and extends into Park and Stillwater Counties. It is drained by the Stillwater and Boulder Rivers, which flow northeastward to the Yellowstone River, and its center lies approximately at lat $44^{\circ} 25^{\prime} \mathrm{N}$. and long $110^{\circ} \mathrm{W}$. This layered igneous massif, which is classed by Hess $(1960$, p. 3) as a lopolith, has a length of about 28 miles, a maximum width of 5 miles, and trends $\mathrm{N} .70^{\circ} \mathrm{W}$., dipping about $55^{\circ}$ northward.

The country rock of this area is an uplifted mass of schist and gneiss, intruded by peridotite, anorthosite, norite, and gabbro, which occur in dikes, sills, and bodies of irregular shape and constitute the Stillwater Complex. The schist, gneiss, and most of the intrusives are of Precambrian age, though some intrusives of Cretaceous or Tertiary age have also been recognized. The basic and ultrabasic intrusives are overlain unconformably on the north by folded sedimentary rocks of Paleozoic age; and windows of the crystalline rocks are visible within the sedimentary sequence.

The Stillwater Complex was divided by Howland, Peoples, and Sampson (1936) into four principal zones, as follows:

1. Upper zone, thickness 3,500 feet. This consists of anorthosite, anorthositic gabbro, and anorthositic norite. 
2. Banded zone, thickness 5,000 feet. This consists of norite, gabbro, and anorthositic norite, with a band of troctolite near the top, and narrow bands of anorthosite in the basal horizons. At least two bands containing platiniferous sulfides are present.

3. Ultrabasic zone, thickness of 2,500 feet. This consists mainly of bronzitite, harzburgite with chromitic bands, and subordinately dunite, commonly serpentinized.

4. Basal zone, a thickness 300 feet. This consists mainly of diabasic norite.

Later these rocks were subdivided by Hess (1960, p. 50) into 10 zones, of which only the ultrabasic and basal zones correspond with those of Howland, Peoples, and Sampson. Hess also added 4,890 feet to the section and inferred that another 10,600 feet of these rocks have either been eroded or are concealed below the superjacent Paleozoic beds. Later, Jackson (1961) subdivided the ultrabasic zone into two units, consisting of an upper or bronzitite member underlain by a lower or peridotite member. For the purpose of this description, the four divisions of Howland, Peoples, and Sampson, including the two members of the ultrabasic zone, are most useful.

Platinum-bearing minerals have the greatest interest in the Stifliwater Complex. Such deposits are stated by Howland, Peoples, and Sampson (1936, p. 10-11) to be of three types. Platinum and palladium have been identified by chemical analyses in the banded zone; chromite deposits occur in the ultrabasic zone; and nickel-copper minerals with small amounts of the platinum elements are present at the basal contact of the complex. The minerals chalcopyrite, pentlandite, and pyrrhotite, which are present in the banded and basal zones, are interstitial to the silicate minerals that form the bulk of these rocks and partly replace some of them. Most, if not all, the platinum metals are believed to occur as platinum minerals that are included as minute crystals in the sulfides of iron, copper, and nickel. The only one of these minerals that has been definitely identified was stibiopalladinite, though sperrylite is probably also present. Native platinum alloys have not been recognized.

Recently, Page and Jackson (1967) have studied the ultrabasic zone and have found at certain of its chromitite horizons a number of sulfides, arsenides, antimonides, and possibly selenides that contain iron, copper, nickel, cobalt, molybdenum, and tin, some of which may be platinum bearing. Platinum-group minerals have also been identified, either in grains of chromite or interspersed with the silicate minerals of the chromitites. One of these is laurite, but others have been recognized that appear to correlate with some of those described by Stumpfl (1961), as mentioned on page 13 of this report.

Concentrations of nickel-copper minerals were found by Howland, Peoples, and Sampson at three principal horizons, of which two were in the banded zone, and one was at the lower contact of the basal zone. Six samples were submitted to the U.S. Geological Survey for analysis, including one from the ultrabasic zone. Four of these were found to contain small amounts of platinum and palladium, with traces of iridium, ruthenium, and rhodium. Osmium was not identified. The localities of these samples, and the results of their assays, are given in table 42.

TABLE 42.-Analyses of rocks in ounces per ton, from the Still-. water Complex, Montana

[Analysts, S. F. Cress and K. J. Murata, U.S. Geological Survey]

\begin{tabular}{|c|c|c|c|c|c|c|}
\hline & MB-215 & EB-308 & NP-2 & $M B-236$ & $G-13$ & $\mathrm{H}-5-37$ \\
\hline $\begin{array}{l}\text { Platinum } \\
\text { Iridium } \\
\text { Ruthenium } \\
\text { Rhodium }\end{array}$ & 0.006 & & $\begin{array}{l}0.1 \\
\text { Tr. } \\
\text { Tr. } \\
\text { Tr. }\end{array}$ & 0.004 & & $\begin{array}{l}0.007 \\
\ldots\end{array}$ \\
\hline Palladium.... & .001 & -... & .2 & .007 & & 01 \\
\hline
\end{tabular}

MB-215. McHugh's prospect, east side of valley of Boulder Creek, and 1 mile south of the Boulder Ranger station, at an altitude of $6,000 \mathrm{ft}$, Sweetgras County. Anorthosite with disseminated chalcopyrite, pyrrhotite, and
pentlandite. Sample from banded zone.

EB-308. West side of Canyon of Lewis Creek, East Boulder plateau, Sweetgrass County. A northosite with 15 to $20 \mathrm{ft}$ patches of disseminated pyrrhotite. chalcopyrite, and pentlandite in a 300-ft zone of same material. Sample

NP-2. Near head of North Fork of Picket Pin Creek, Sweetgrass County. An orthosite with 10-ft patches of disseminated pyrrhotite, chalcopyritc, and pentlandite in a 50-ft zone of same material. Sample from banded zone, and thought to represent the same igneous horizon as samples $\mathrm{MB}-215$,

MB-236. East side of valley of Bould $3 r$ Creek, about 3 miles south of the Boulder Ranger station, Sweetgrass County. From band of norite with disseminated pyrrhotite, chalcopyrite, and pentlandite. Sample from banded zone, but thought to represent a lower horizon than the three preceding
samples. samples.

Dith side Blakely Creek, tributary Boulder River, Sweetgrass County. Dunite with disseminated chromite. Ultrabasic zone. valley of the Stillwater River, Stillwa. 2 level, "G" layer. West side o contact of the basa! zone, from sulfide ore that transects a layer of chromite.

Two analyses of rocks from the Stillwater Complex, Montana, made by the International Nickel Co. of Canada, Ltd., (Howland and others, 1936, p. 11) are given in the following tabulation:

Upper horizon, below base of
the complex
banded zone

The methods used in selecting the samples that have been assayed are not known to the writer. If, however, these assays were made on samples of crude broken rocks, even if they were finely crushed and properly parted, the results may not be too dependable. The only proper method for sampling such low-grade ores is to crush and mill them and thereafter to con- 
centrate the sulfides or other ore-bearing minerals by the use of a gold pan, or a Wilfley table. Much better assays can be obtained on such enriched samples, and better average values will result. The degree of concentration prior to chemical analysis is readily determinable.

Another phase of this problem must also be stressed. Many assayers who are capable of making high-grade analyses of gold, silver, and the base metals are either too inexpert or unwilling to make high-grade analyses of the platinum metals. This is due in part to the fact that some of the better methods have not been published, but may also result because such analyses are time consuming and costly. The processors of the platinum metals and the Bureau of Standards are perhaps the most reliable sources for such analytical work.

The Stillwater Complex, owing to the occurrence within it of ultrabasic rocks and zones of chromitite, appears to be more closely related to the Bushveld igneous complex of the Transvaal than to the elongate "norite" irruptive of the Sudbury district. In one respect only is there a simulative relationship with the latter. Significant deposits of platiniferous nickelcopper ores are not generally present within the "norite" irruptive, but occur instead either as marginal or offset ore bodies. The Mouat-Sampson mine, of Stillwater County, which is at the lower contact of the basal zone and is associated with noritic rocks is the only property in this area that has been developed. Moreover, according to Howland and others (1936), the Stillwater Complex, for over half its length, is in contact with an iron-stained quartzite of Precambrian age, with a thickness of 200 feet, that is analagous to the Mississagi quartzite of the Sudbury district. Finally, quartz monzonite intrudes both this quartzite and the basal zone of the Stillwater Complex. This similarity, which may in fact be quite fortuitous, is nevertheless a reason for further prospecting along or near the lower contact of the basal zone.

\section{GREEN MOUNTAIN COPPER MINE}

Another property in Montana where platinum has been found is the Green Mountain copper mine, in the Revais Creek district, near Dixon, Sanders County. The ore occurs mainly in a vein about 5 feet thick, which follows a fault contact between a gabbro and a quartzite, of the Belt Series. The principal ore minerals are chrysocolla and malachite, and the mine was operated for its content of copper, with a byproduct of gold, silver, and platinum metals. About 5,000 tons of ore was mined intermittently at this property between 1910 and 1942 , but the returns were such that the oper- ation was not profitable. Smelter returns between 1938 and 1942 indicated a tenor of about 0.08 ounce of platinum and palladium to the ton of ore. The sources of these platinum metals were not determined, but probably they occurred originally as platinum minerals in unoxidized sulfide ores at greater depth. At least 300 ounces of platinum metals was produced during the lifetime of this mine.

\section{PLACERS}

Placer platinum has been reported from several localities in Montana. One of these, with which the writer is personally familiar, comprised the several terraces along both sides of the Missouri River, in Lewis and Clark County, downstream from the Canyon Ferry dam (Mertie, Fischer and Hobbs, 1951, p. 80). The gravels on these terraces were mined for their contents of gold, and at Eldorado Bar, on the north side of the river and 73/4 miles northwest of Canyon Ferry, a dredge was operated from 1938 to 1944. At this site, it was estimated that 8.84 troy ounces of platinum of platinum metals was recovered per 100 pounds of wellcleaned placer concentrates. The platinum from these concentrates was analyzed by the Wildberg Smelting and Refining Co., of San Francisco, and the resulting analysis is platinum 88.91 percent, iridium plus osmium 6.34 percent, palladium 4.75 percent, rhodium not determined, ruthenium not recognized, totàl 100.00 percent.

\section{NEVADA}

The Boss mine is in the Yellow Pine mining district, of Clark County, Nev. This ore deposit was discovered about 1886 and was worked intermittently for copper and gold for 28 years. Platinum was discovered in 1914, and thereafter the mine was worked until 1919. The Boss deposit was an ore shoot of ellipsoidal shape which followed the hanging wall of a fault zone in thick-bedded limestone of Mississippian age. The deposit is not cut by granitic rocks, but a granitic dike appears about 1,500 feet northeast of the mine.

The ore body, from the available descriptions, appears to have been an ellipsoidal ore shoot with a length of about 200 feet and a maximum width of about 25 feet; smaller bodies are also recorded. The ore minerals consisted of dark cellular masses of quartz that contained chrysocolla, limonite, and local concentrations of chalcopyrite, bornite, chalcocite, malachite, and cuprite. Within the ore body were stratified masses and narrow veins of plumbojarosite which was determined by earlier observers to be the source of the precious metals. A sample of this talclike material, collected by Adolph Knopf $(1915$, p. 878), was analyzed by F. C. Wells, of the U.S. Geological Survey; but the material was 
afterwards determined by W. T. Schaller, of the U.S. Geological Survey, to have been a mixture of plumbojarosite, beaverite, and bismutite. Hence, the analysis is of value mainly for the tenors of platinum and palladium that were determined. The stated values show that for such picked ore the tenors of platinum and palladium per ton of ore were respectively 14.6 and 64.2 troy ounces.

The tenors of the platinum ore and crude ore that was mined, however, are much smaller. One assay by Hale (1914) and two other sets of data published by Hewett (1931) bear upon this question. From Hewett's data, one can obtain the weighted mean values of the smelter returns on the "platinum ore" for 1916-19, and the weighted mean tenors of the crude ore for 1917-19. These three values are given herewith:

Hale: 0.5 to 1.0 ounce platinum per ton of ore. Hewett: 0.32 ounce platinum and 1.10 ounces palladium per ton of "platinum ore."

Hewett: 0.05 ounce platinum and 0.11 ounce palladium per ton of crude ore, or 0.16 ounce platinum metals per ton.

The ratio of platinum to palladium, as gaged by the analysis made by the U.S. Geological Survey, was 1:4.4. The same ratio as gaged by Hewett's smelter returns was $1: 3.5$.

The mode of occurrence of the platinum and palladium in the plumbojarosite has not been determined. It was suggested by Knopf (1915a, p. 8) that the mineral sperrylite might be present, but this idea was properly rejected by Hewett. Moreover, the platinumpalladium ratio of approximately $1: 4$ does not fit with this interpretation. From what is now known of the numerous platinum minerals as earlier stated in this report, it is probable that the platinum and palladium exist as separate minerals in the sulfides or other metallic minerals of the ore.

The Boss mine is frequently cited as an unusual occurrence of the platinum metals in a quartz vein. This deposit, however, is not unique in this respect, as the same or similar associations have been recorded at many other places in the world. Among the better known of these are the following:

1. Gold Hill mine, of the Gold Hill quadrangle, Oregon.

2. Quartz veins in West Point mining district, Calaveras County, Calif.

3. Gold quartz vein at property of Roll Call Mining Co., near Villa Grove, Calif.

4. Quartz vein near Boyerstown, Pa.

5. Gold quartz vein at Mother Lode claim, Burnt
Basin, 3 miles west of Coryell, Yaie district, British Columbia.

6. Quartz vein in granodiorite in Ainsworth mining district, British Columbia.

7. Gold quartz vein in Union Mine, Grand Forks division, British Columbia.

8. Gold quartz vein at mine of Northern Manitoba and Development Co., near The Pas, Manitoba.

9. Quinn claims near the Croesus mine, Munro Township, Ontario.

10. Gold quartz veins in Halifax County Nova Scotia.

11. Guadalcanal, a few miles northeast of Rio Tinto district, Spain.

12. Near Chatelard, Vallee du Drac, Haute Alpes, France.

13. Quartz veins in Thames gold field, North Island, New Zealand.

14. Quartz veins of Hauraki district, North Island, New Zealand.

15. Massive pyrite at Coromandel, North Island, New Zealand.

16. Quartz veins in ultrabasic rocks, North Westland, South Island, New Zealand.

17. Quartz veins associated with serpentine, Teremakau River, South Island, New Zealand.

18. Quartz veins in Lucknow and Alma auriferous reefs, at Gympie, New South Wales.

19. Boa Esperanca veins, Minas Gerais, Brazil.

20. Santa Rosa, north of Medellín, Antioquia, Colombia.

21. Quartz veins of the Waterberg district, Republic of South Africa.

22. Platinum-bearing gold quartz veins of Beresovsk district, Ural Mountains.

23. Quartz veins of northern Finland.

None of these deposits, however, is an important source rock of the platinum metals. They show merely that the platinum metals are not restricted to ultrabasic and basic rocks.

The authenticity of some of the occurrences quoted above may be questioned, particularly at sites where native platinum alloys have been found. It is well known to placer miners that the precious metals at the base of many placers have penetrated downward for 10 to 20 feet into shattered bedrock. If it should happen that the bedrock below a placer consisted of vein quartz, which is brittle and readily shattered, native gold and platinum could readily penetrate into such rock and form an ore body that simulated a gold-platinum lode. The fact that such a lode is far removed from any present stream is immaterial, as alluvial deposits have existed and have been eroded from many 
sites. Any gold-platinum lode wherein the precious metals are confined to the uppermost part of the vein is therefore subject to suspicion. In any event, this contingency needs to be disproven before acceptance of all the cited quartz veins as carriers of pratinum metals.

Two other prospects in Nevada merit mention. These, known as the Key West and Great Eastern prospects, are in the Copper King mining district, about 25 miles east of Moapa, and about 100 miles northeast of the Boss mine. They were described by Bancroft (1910) as a group of peridotite dikes that consist mainly of augite, olivine, and enstatite, with the accessory minerals pyrrhotite (thought to be nickelferous), chalcopyrite, and magnetite. A shipment of 45.8 tons of ore from the Key West prospect showed tenors of 0.13 to 0.15 ounce of platinum metals to the ton. No recent work has been done.

\section{OREGON}

The platinum metals found on the beaches of Oregon and California appear to have originated in bodies of peridotite and serpentinite. The great dike of serpentinite that crops out in the valley of the Applegate River, a north-flowing tributary of the Rogue River, and continues northward may be such a source rock. Platinum was located in the Highland mine, about 12 miles south of Gold Hill, in the Gold Hill quadrangle, Oregon. According to Kellogg (1922, p. 1000), this metal was finally traced to a bluish quartz that was taken from the 100-foot level of the Gold Hill mine. The tenor in platinum, as given by smelter returns, was 0.32 ounce per ton of ore. Serpentinite, however, is probably the major source.

PLACERS

Platinum-bearing gold placers have been found and mined at three localities in Oregon. The most important of these was the Takilma-Waldo district, in Josephine County, about a mile northeast of Waldo and about 30 miles southwest of Grants Pass. Gold was discovered in 1953 on Althouse Creek and thereafter was mined for many years, particularly before 1917 but also up to 1930 . A second but less important site was on Applegate River, about 25 miles northeast of Waldo. The third locality consisted of the Pacific beaches of Curry and Coos Counties, which were discovered in 1852 and were worked intermittently for many years. According to Shenon (1933, p. 179), the minimum production of the platinum-bearing gold placers of the Takilma-Waldo district up to 1930 was $\$ 4$ million, but no estimate is available for Applegate River and its tributaries. No record was kept of the early production of gold and platinum from the ocean beaches of Ore- gon, but according to Pardee (1934, p. 26), quoting from the U.S. Bureau of Mines, the production of gold between 1903 and 1929 was about $\$ 60,000$, of which about $\$ 2,000$ was platinum.

The production of platinum from Oregon in the period 1880-1903, with 9 years not recorded, is given by Quiring (1962, p. 254) as 675 troy ounces, with a maximum output in 1895 of about 130 ounces. Using a gold-platinum ratio of 100:1 for the Takilma-Waldo district, and rating platinum at twice the value of gold at that time, this district may have produced about 1,000 ounces.An unknown part of this output should be added to that given by Quiring for the period 1880-1903, so that the production of platinum metals from Oregon may have been as much as 1,500 ounces.

$$
\text { TAKILMA-WALDO DISTRICT }
$$

The deposits of the Takilma-Waldo district include both Tertiary and Quaternary placers. The Tertiary placers, which are in Tertiary conglomerate, are composed of large, greatly altered, boulders of greenstone, granite, argillite, and other rocks in a well-indurated sandy matrix. Gold and platinum are distributed throughout the conglomerate and are only slightly concentrated near bedrock, which suggests local sources. Well-known deposits in the Tertiary conglomerate that were worked at a profit were the High Gravel, Cameron, and Platerica mines. The ratio of gold to platinum is reported to have ranged from $75: 1$ to $100: 1$, but no assays or analyses of the platinum appear to have been made. The principal heavy and semiheavy minerals recovered with the precious metals were chromite, magnetite, limonite, hematite, ilmenite, epidote, and zircon.

The more valuable deposits of the Takilma-Waldo district were gravel deposits on terraces or in the present valley floors One of the best known properties of this group was the Logan mine, later known as the Llano de Oro mine, but best known perhaps as French Flat. This was a terrace from 15 to 20 feet high, on the west side of the East Fork of the Illinois River, about a mile northeast of Waldo. The deposit consisted of imperfectly sorted gravel, sand, and clay ranging in thickness from a foot at its outer edge up to 50 feet. The gold was angular and was associated with chromite, magnetite, ilmenite, hematite, limonite, epidote, and zircon. The ratio of gold to platinum was reported to have been about 50:1. According to Shenon (1933, p. 187), a sample of the platinum was analyzed by E. T. Erickson, of the U.S. Geological Survey, who reported that it consisted largely of platinum and ruthenium, less iridium and osmium, and very small amounts of palladium and rhodium. This 
analysis differs from any other known to the writer, and if reliable, is indeed unique.

Other deposits worked in the Takilma-Waldo district were the Deep Gravel mine, and those on Fry, Waldo, Allen, Butcher, and Sailor Gulches. These properties were mainly in the vally floors of the present streams and were concentrated from the Tertiary conglomerate, which constituted a proximate source rock. Platinum was undoubtedly recovered from these deposits, but its presence was not mentioned either by Hornor (1918) or by Shenon (1933).

\section{APPLEGATE DISTRICT}

Applegate River is a northwest-flowing tributary of Rogue River. Mining was carried on in the Applegate district for years after mining ceased in the TakilmaWaldo district. A nonfloating dredge, probably mounted on skids and moved by a caterpillar, was operated on the Applegate River in 1944, and two others were operated in the Applegate drainage. In addition, some mining was in progress on Forest and Poorman Creeks, tributaries of the Applegate River. The following analysis of platinum, made by the Wildberg Smelting and Refining Co. of San Francisco, was given to the writer by an operator on the Applegate River: platinum 29.70, iridium 31.96, osmium 25.56, ruthenium 12.78, rhodium not determined, total 100 percent. This is clearly a mixture of osmiridium with ordinary platinum, wherein osmiridum is a major component.

\section{PACIFIC BEACHES}

The beach deposits of Oregon have been well described by Pardee (1934). In Curry County the principal localities, named from south to north, were the mouth of Chetco Creek, Ophir Creek, the mouth of Pistol River, Gold Beach at the mouth of the Rogue River, Eucher Creek, Port Orford, and Cape Blanco near the mouth of the Sixes River; in Coos County, Bandon at the mouth of the Coquille River, Old Randolph on South Slough, and Coos Bay at the mouth of Coos River. These deposits were discovered in 1852, and those of higher grade were soon exhausted, yet many of them were worked intermittently for years afterwards.

The coastal ranges of Oregon are bounded on the west by a narrow Pacific coastal plain that ranges in width from a quarter of a mile to 4 miles and in altitude from sea level to 100 feet, with numerous low marine terraces. There are also higher terraces at or about 170 feet above sea level and one higher terrace at an altitude of 800 feet. Deposits at the 170 -foot level were worked at two mines east of Cape Blanco and at four mines north of Cut Creek. The Peck mine, at an altitude of 800 feet, was on a spur north of the Sixes River, and still other terraces up to an altitude of 1,500 feet are present, though none of these was mined. The terrace deposits, however, proved not to be as high grade as those in the coastal plain or low terraces. Probably the richest deposits were found south of Coos Bay, but the beaches at Whisky Kun, Cape Blanco, Port Orford, and Gold Beach were also remunerative.

The platinum metals and the gold are extremely fine, rounded, flat grains from 0.8 to 0.05 millimeter in diameter and from 0.05 to 0.005 millimeter in thickness, but range downward to grains of microscopic size. The ratio of gold to platinum varied from 100:1 to $160: 1$. The heavy and semiheavy minerals on the Port Orford and adjacent beaches were found to be mainly magnetite, chromite, ilmenite, garnet, and olivine. Some zircon and monazite were also found at Coos Bay.

Two chemical analyses, which are believed to represent the platinum of the littoral deposits, have been published and are presented in table 43 . It may be assumed that most of the "osmium plus iridium" recorded in table 43 is iridium, but these analyses, owing to the high percentage of platinum, do not represent osmiridium alone. On the other hand, the high tenors in osmium plus iridium indicate that much osmiridium is present. If these analyses represent an alluvial mixture of two alloys, as may well be true, they suggest that the ratio of osmiridium to platinum is high. Owing to the low percentage of rhodium, these two analyses do not correspond closely with any of those recorded for California.

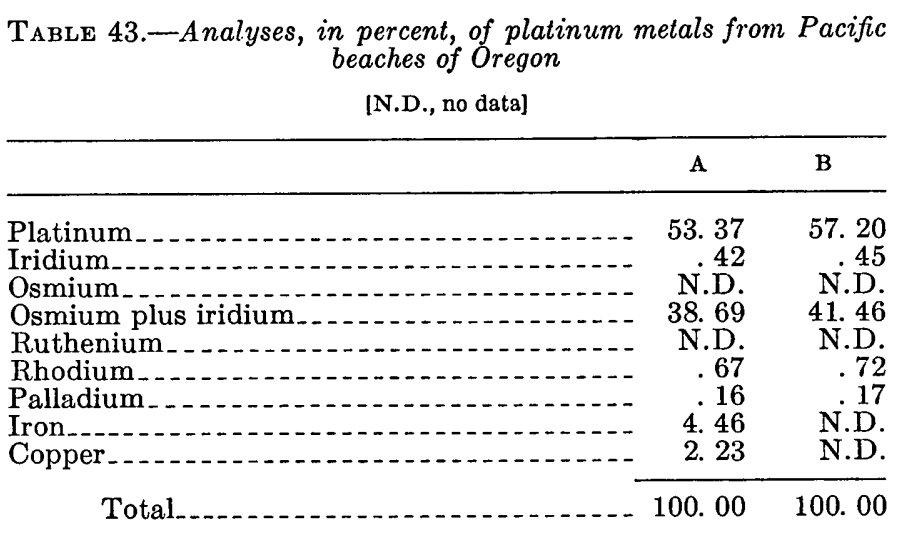

A. Deville and Debray (1859); republisbed by Kemp (1902, p. 19). B. Deville and Debray (1859).

Platinum metals have been found, generally as traces, in many other counties of Oregon, and from Baker County there was a small production in 1925 . Platinum has been identified in Jackson, Douglas, Lincoln, Linn, Clatsop, Washington, and Multnomah 
Counties, in the western part of the State; Wheeler and Grant Counties, in the central part; and Union County, north of Baker County, in the eastern part of the State.

\section{WASHINGTON}

Gold was found along the beaches of Washington about 1894, and the ground was staked for 60 to 70 miles south of Cape Flattery, Clallam County; but the productive strip was later determined to be from Portage Head, about 8 miles south of Cape Flattery to Cape Johnson, just north of Quillayute River. The most productive locality was at Shi Shi Beach, near Portage Head, where at least $\$ 15,000$ in gold was recovered prior to 1904 . The total production of gold probably did not exceed 1,500 troy ounces. The material from which the gold was concentrated, however, was of glacial origin, and the ratio of gold to platinum was estimated to have been from 15:1 to 5:1. Therefore, although the platinum was probably overlooked, some 150 ounces of platinum may have been handled in these operations. It was later determined that the grains of platinum were only about one-fourth as large as those of the gold and that about 10 percent of them were ferromagnetic.

Gold and platinum were also produced on a small scale along a short stretch of the South Fork of Lewis River, a short distance above Moulton, in Clark County. A few ounces of platinum metals are reported to have been produced. Traces of platinum metals have also been found in Pacific, Lewis, Thurston, King, Skagit, and Whatcom Counties, in western Washington; in Okanogan County, in north-central Washington; and in Garfield County, in southeastern Washington.

\section{WYOMING}

The Rambler mine and nearby Centennial mine merit brief mention. The Rambler mine is in the Medicine Bow Mountains, about 10 miles north of the Colorado line and about 45 miles west of Laramie City. This is an ore deposit of irregular shape, which occurred in a dike or small stock of dark-colored greatly decomposed diorite, bounded by quartzite. The Centennial mine was in gneiss and schist. The ore minerals of the Rambler mine were covellite, chalcopyrite, pyrite, cuprite, azurite, malachite, and kaolin. The feature of greatest interest was the recogniton of extremely minute crystals of sperrylite intergrown with the covellite. The source of the palladium contained in the ore was not ascertained. According to Taft (1918, p. 900), the tenors of platinum and palladium in the ore were respectively 0.6 and 0.4 ounce per ton of ore; and another assay from an independent source showed a total of 1.3 ounces of platinum metals to the ton of ore.
According to Paul Theobald of the U.S. Geological Survey (written commun., 1967), preliminary analyses of samples from the mine dump show from 0.2 to 20 parts per million (0.006-0.6 ounce per ton) of platinum metals, and check analyses of five samples showed 2.1 to 4 parts per million. The ratio of palladium to platinum is about $5: 1$. The Rambler mine was a small deposit which was quickly exhausted.

\section{RECOVERIES FROII REFINERIES}

Platinum metals are recovered in the mining of gold and copper from refineries where these two metals are purified, and also from secondary sources. The amount obtained from copper ores may properly be classified as a product of lode mining, whereas that recovered from gold ores and bullion is an increment gained both from lode and placer mining. The platinum metals from the placer deposit at Goodnews Bay, Alaska, together with any such metals that originate as a byproduct of other gold placer mining, are combined with those derived from all primary domestic sources to arrive at the output of 35,026 troy ounces cited in table 2 as the production for 1965. In addition, there was an output of 106,525 ounces obtained from domestic secondary sources. Hence, more than a million ounces of platinum metals had to be imported to satisfy the industrial needs of the United States for 1965.

\section{BIBLIOGRAPHIES}

The most exhaustive bibliography on the occurrence, character, genesis, and value of the platinum metals up to 1917 is the "Bibliography of the Metals of the Platinum group, 1748-1917," written by J. L. Howe and H. G. Holtz, and published as U.S. Geological Survey Bulletin 694. Howe, after leaving the Geological Survey, continued his bibliographic work under the auspices of and in collaboration with the staff of Baker and Co., Inc. of New York. Three volumes were published by Baker and Co. covering the periods 191830, 1931-40, and 1941-50. These volumes, however, were quite different in character from Howe's original bibliography in that they specialize on the physical and chemical properites of the platinum metals, and neglect almost entirely the fields of geology and mineralogy. For example, the only major platinum deposit in the United States, at Goodnews Bay, Alaska, is not listed in either of the last two volumes.

An older bibliography of 150 titles on iridium, for the period 1803-85, deserves mention. This was prepared by A. N. Perry and appeared in the U.S. Geological Survey Mineral Resources volume for 1883-84. 
A third bibliography of the physical properties of the platinum metals and their alloys by Douglass and Jaffee (1960), is also very useful.

The following bibliography is separated into two parts, one of which refers to foreign occurrences and the other to occurrences in the United States. Some descriptions of domestic deposits that were published in foreign journals or handbooks have been included both in the foreign and in the American bibliography. Among these are the work of Duparc and Tikonowitch (1920) on the Uralian placers, wherein are presented some comparative data on occurrences in the United States, and foreign reference books such as the Handbuch der Mineralchemie, by Doelter and Leitmeier (1932), Gmelin's Handbuch der anorganischen Chemie (1938, 1939), and Die metallischen Rohstoffe, Platinmetalle, by Quiring (1962), all of which refer to numerous American localities where platinum has been found.

\section{FOREIGN BIBLIOGRAPHY}

Adam, H.R., 1927, A note on a new platinum mineral from the Potgietiersrust platinum fields; Chem. Metall. Mining Soc. South Africa Jour., v. 28, p. 249-250.

1930, Notes on platinum group minerals from Rustenburg and Potgietersrust districts, Transvaal. Geol. Soc. South Africa Trans., v. 33, p. 103-111.

- 1933, A note on the minerals cooperite and braggite occurring in platiniferous concentrates from the Transvaal : Chem. Metall. Mining Soc. South Africa Jour., v. 34, p. 132-136.

Aho, A. E., 1956, Geology and genesis of ultrabasic nickelcopper-pyrrhotite deposits at the Pacific Nickel property, British Columbia: Econ. Geology, v. 51, p. 444-481.

Al'bov, M. N., 1956, Possibility of the occurrence of platinum in quartz veins: Vses. Mineralog. Obshch., Zapiski, v. 85, p. 212-215.

Allan, J. D., 1950, The Lynn Lake nickel area, Manitoba: Canadian Mining and Metall. Bull. 461, p. 509-514.

Allen, C. C., 1959, Platinum metals ; review 18; Internat. Nickel Co. Canada Ltd., Canada Dept. Mines and Tech. Surveys, Sudbury, Ontario, p. 1-3.

1960, The platinum metals: Canada Dept. Mines and Tech. Surveys, Mineral Resources Div., Mineral Report 3, 68 p. [1961].

- 1961, Mineral reviews, nickel : Canadian Mining Jour., v. 82, no. 2, p. 138.

Aminoff, G., and Parsons, A. L., 1928, The crystal structure of sperrylite: Toronto Univ. Studies, Geol. Ser., no 27, p. 5-10.

Anderson, P. F., 1958, Ultra-deep mining at East Rand Proprietary Mines: South African Mining and Eng. Jour., Aug. 15, 1958, p. 321-325.

Andrews, E. C., 1922a, The geology of the Broken Hill district: New South Wales Geol. Survey, Geology Mem. no. 8, 1922, p. $102,103,150,170,191,260,261,286,294$, and 340-342. 1922b, Notes on the geology of the Broken Hill district: Econ. Geology v. 17, p. 470-490.

1925, The platinoid deposits of Broken Hill : New South Wales Dept. Mines Ann. Rept. 1925, p. 101-102.
Australia, 1956, Mineral resources of Australia ; platinum group metals: Bur. Mineral Resources, Geology and Geophysics, Rept. no. 39, 22 p.

- 1957, Mineral resources of Australia; platinum group metals: Bur. Mineral Resources, Geology and Geophysics, v. 9, p. 1-37.

Baievsky, B., 1926, Siberia; its resources and possibilities: U.S. Dept. Commerce Trade Promotion Ser., no. 36, p. 39 .

Baird, J. D., 1960, Properties of ruthenium, osmium, and iridium; melting point and hardness determinations: Platinum Metals Rev., v. 4, no. 1, p. 31. Also Research Laboratory of Associated Electrical Industries, Ltd., Aldermaston, England, Rept. no. A.843.

Baker, M. B., 1917, Alexo nickel mine, Timiskaming district: Ontario Bur. Mines, Ann. Rept. 26, p. 258-274.

Ball, S. H., and Shaler, M. K., 1914, Mining in the Belgian Congo in 1913: Mining and Sci. Press, v. 108, p. 320-325. - 1914, Economic geology of the Belgian Congo, central Africa: Econ. Geology, v. 9, p. 605-663.

Balzak, S. S., Vasyutin, V. F., and Feigin, Y. G., 1949, Economic geography of the U.S.S.R.: Translation of v. 1 of Russian ed. of 1940. New York, The Macmillan Co.

Bannister, F. A., 1932a, The discovery of braggite: Discovery, v. 13 , p. $384-387$.

- $1932 \mathrm{~b}$, Determination of minerals in platinum concentrates from the Transvaal by X-ray methods: Mineralog. Mag., v. 23, p. 188-206.

Barlow, A. E., 1904, Report on origin, geologic relations, and composition of the nickel and copper deposits of the Sudbury mining district, Ontario: Canada Geol. Survey Ann. Rept., v. 14, pt. 1, 97 p.

- 1906, On the origin and relations of the nickel and copper deposits of Sudbury, Ontario : Econ. Geology, v. 1, p. $454-466$.

Barrera Arenas, Tomás, 1946, Guía geológica de Oaxaca, México: Mexico (City) Univ. Nac. Inst. Geología, 101 p.

Bawden, W. E., 1925, The Creighton mine: Canadian Inst. Mining and Metallurgy, v. 28, p. 1054-1068.

Beath, C. B., Cousins, C. A., and Westwood, R. J., 1961, The exploitation of the platiniferous ores of the Bushveld igneous complex, with particular reference to the Rustenburg platinum mines: Commonwealth Mining and Metall. Cong., 7th, South Africa, Trans., v. 1, p. 217-243.

Beath, C. B., Westwood, R. J., and Cousins, C. A., 1961, Platinum mining at Rustenburg; the development of operating methods: Platinum Metals Review, v. 5, p. 102-108.

Beder, Roberto, 1930, Sobre la existencia de platino nativo en una serpentina de Alta Gracia: Revista Minera, Geología y Mineralogia (Soc. Argentina de Minería y Geología) v. 2 , p. 97 .

Belezkij, Wladimir, 1959 Sôbre uma ocurrência singular de platina da parte central da Serra do Cipó : Rio de Janeiro, Brazil Divisão da fomento da Produção Mineral, Boll. no. 106, $102 \mathrm{p}$.

Bell, J. M., 1906, The salient features of the economic geology of New Zealand: Econ. Geology, v. 1, p. 735-746.

Bell, Robert, 1891a, Report on the Sudbury mining district, Ontario: Canada Geol. Survey Ann. Rept. 5, new ser., pt. F, p. 1-54.

1891b, The nickel and copper deposits of the Sudbury district, Canada : Geol. Soc. America Bull., v. 2, p. 125-137. 
Berg, Georg, 1941, The occurrence and distribution of the noble metals on the earth: Metallwirtschaft, v. 20, p. 118-121 (in German) :

Besaire, H., 1933, Etude des alluvions: La Chronique des Mines Coloniales (Bur. d'Etudes Géol. et. Min. Coloniales), an. 2 , no. 17 , p. $368-378$.

- 1959, La recherche géologique à Madagascar de 1948 a 1958: Soc. Hist. Nat. Toulouse, จ. 60, 59 p.

Betechtin, A. G., 1930, Peculiarities of primary platinum ores from the Urals: Gorni Zhurn., v. 106, p. 152-161. (Abs., Brit. Chem. Abs., 1932, A, p. 140).

1935, Character, classification, occurrence, and genesis of platinum minerals depasits of Russia: Acad. Sci. U.S.S.R., 148 p.

1961, Mikroskopische Untersuchungen an Platinerzen aus dem Ural: Neues Jahrb. Mineralogie Abh., v. 97, p. 1-34.

Beyschlag, F., 1923, Uber das Vorkommen platinhaltiger Gesteine in Deutschland [abs.] : Montan. Rundschau, v. 15, p. 241-244.

Bleckrode, S., 1858, Platinerz von Borneo: Poggendoff's Annalen, v. 103, p. 656 .

Böcking, Max, 1855, Mineral-Analysen, Platinerz von Borneo: Annalen der Chemie und Pharmacie, v. 96, p. 243-244.

Borishanskaya, S. S., Rasin, L. V., and Roskov, I. S., 1960, A rare variety of cuprous platinum-collomorphous cuproplatinum: Akad Nauk S.S.S.R., Sibinskaye Otdeleniye, Geologiya i Geofizika, no. 7, p. 50-59 (in Russian).

Borovskii, I. B., Deev, A. N., and Marchukova, I. D., 1959, Use of method of local X-ray spectral analysis to the study of platinum group minerals: Geologiya Rudnykh Mestorozhdenii, no. 6, p. 68-73 (in Russian).

Bostock, H. S., 1929, Geology and ore deposits of Nickel Plate Mountain, Hedley, B. C.: Canada Geol. Survey, Summ. Rept., pt. A, p. 198-252.

Botsford, R. S., 1923, Platinum in the Urals: Mining and Metallurgy, v. 4, p. 595-600.

Bracho, V. F., and Franco, L. M., 1945, Estudio tẻcnico de las propielades mineras y plata de "El Cerdo," de la Cooperativa Minera "Las Dos Estrellas", en El Oro y Tlalpujahua, Michoacán: Bol. Minas y Petróleo, v. 16, no. 6, p. 3-9 and no. 7 , p. $11-43$.

Brouwer, H. A., 1929, The geology of the Netherlands East Indies; Science in the Netherlands East Indies: Amsterdam, Internationale Circumpacifische Onderzock Commissie, printed by De Bussy, p. 122.

Brown, C., 1918, A review of the osmiridium mining industry of Tasmania : Rept. Secretary Mines, Tasmania, p. 133-144.

Buddhus, J. D., 1951, Minerals of the platinum group: Mineralogist, v. 19, p. 350-352.

1958, Native metals widely distributed: Mineralogist, จ. 26, p. $61-62$.

Burrows, A. G., and Rickaby, H. C., 1929, Sudbury basin area : Ontario Dept. Mines Ann. Rept., v. 38, pt. 3, 55 p.

- 1934, Sudbury nickel field restudied: Ontario Dept. Mines Ann. Rept., v. 43, pt. 2, 49 p.

Cabri, L. J., and Trail, R. J., 1966, New palladium minerals from Noril':k, western Siberia: Canadian Mineralogist, v. 8. p. $541-550$.
Cairnes, C. E., 1929, The serpentine belt of Coquihalla region, Yale district, B. C. : Canada Geol. Survey Summary Rept., pt. A, p. 144-197.

Camsell, Charles, 1910, Tulameen district, B. C.: Canada Geol. Survey Summary Rept., 1909, p. 104-117.

- 1910, Platinum mining in the Tulameen district, B. C.: Canada Mining Inst., Quart. Bull. 9, p. 29-44.

- 1913, Geology and mineral deposits of the Tulameen district, B. C.: Canada Geol. Survey Mem. 26, 188 p.

1919, Platinum investigations in British Colombia: Canada Geol. Survey Summary Rept., 1918, pt. B, p. 28-30.

Carmichael, H., and Moore, C. W., 1930, Placer mining in British Colombia: British Colombia Dept. Mines Bull. 2, p. 28-31.

Chhibber, H. L., 1934, The mineral resources of Burma: London, Macmillan, $320 \mathrm{p}$.

- 1946, Platinum in Dhangawan (Jubbulpore district, C. P.) bauxite: Jour. Sci, and Indus. Research, Delhi, v. 4, no. 7 , p. 450 .

- 1947, Platinum and silver in the bauxite of Tungar Hill, near Bassien, Bombay: Jour. Sci. and Indus. Research, Delhi, v. 6, no. 6, p. 81-82.

Cissarz, Arnold, 1930a, Die durchschnittliche Zusammensetzung der Mansfelder Kupferschiefer: Metall. u. Erz, v. 26, p. 316-319.

1930b, Allopalladium und Clausthalit von Tilkerde in Harz, und das Verhältniss von Allopalladium zu Potarit: Zeitschr. Kristallographie, v. 74, p. 501-510.

Cockfield, W. E., and Walker, J. F., 1932, Geology and placer deposits of Quesnel Forks area, Cariboo district, B. C.: Canada Geol. Survey Summ. Rept., 1932, pt. A1, p. 100 , 112 , and 125.

Codazzi, R. L., 1929, Aluviones platiniferos: Bol. Minas $\mathbf{y}$ Petróleo, v. 2, p. 199-213.

1934, Platino: Bol. Minas y Petróleo, v. 11, p. 55-56.

Coertze, F. J., 1958, Intrusive relationships and ore deposits in the western part of the Bushveld igneous complex: Geol. Soc. South Africa Trans., v. 61, p. 387-400.

Coetzee, C. B., 1960, The geology of the Orange Free State gold-field: South Africa Geol. Survey Mem. 49, 198 p.

Cole, G. B., 1953, A nickel-copper deposit on the rim of the Arctic: Western Miner, v. 26, p. 38-40.

Coleman, A. P., 1905, The Sudbury nickel field: Ontario Bur. Mines, Rept. 14, pt. 3, 188 p.

1907, The Sudbury laccolithic sheet: Jour. Geology, v. 15 , p. $759-782$.

- 1913, The nickel industry, with special reference to the Sudbury region, Ontario: Canada Dept. Mines Bull. 170, $206 \mathrm{p}$.

1915, The origin of the Sudbury nickel deposits: Econ. Geology, v. 10, p. 390-393.

1916, Geological relations of the Sudbury nickel ores: Eng. and Mining Jour., v. 102, p. 104-105.

— 1923, The Sudbury area: Ontario Dept. Mines Guide book to Sudbury, Cobalt, etc. : p. 10-48.

- 1924, Geology of the Sudbury nickel deposits: Econ. Geology, v. 19, p. 565-579.

Coleman, A. P., Moore, E. S., and Walker, T. L., 1929, The Sudbury nickel intrusive: Toronto Univ. Studies, Geol. Ser., no. 28 , p. 5-54. 
Coles, B. R., 1964, The magnetic properties of platinum metals and alloys; a survey of recent research: Platinum Metals Rev., v. 8, no. 1, p. 9-11.

Collins, W. H., 1934, The life history of the Sudbury nickel irruptive, pt. 1 Petrogenesis : Royal Soc. Canada Trans., 3d ser., v. 28 , p. $123-177$.

1935, The life history of the Sudbury nickel irruptive, pt. 2 Intrusion and deformation: Royal Soc. Canada Trans., $3 d$ ser., v. 29 , p. $27-47$.

1936, The life history of the Sudbury nickel irruptive, pt. 3 Environment: Royal Soc. Canada Trans., 3d ser., v. 30, 29-53.

1937, The life history of the Sudbury nickel irruptive, pt. 4 Mineralization: Royal Soc. Canada Trans., 3d ser., v. 31, p. $15-43$.

1937, Timiskaming sub-province: Geol. Soc. America Bull. 48 , p. 1427-1458.

Colombia Servicio Geológico Nacional, 1946, Mapa geologico general Intendencia del Chocó: scale 1:500,000 [Bogotá].

Condon, E. J., ed., 1963, Geological map of Victoria, 2d. edition : Melbourne, Dept. of Mines, Geol. Survey of Victoria. Scale $1: 1,000,000$.

Cooke, H. C., 1946, Problems of Sudbury geology, Ontario: Canada Geol. Survey Bull. 3, 77 p.

- 1948, Regional structure of the Lake Huron-Sudbury area-Canadian Inst. Mining and Metallurgy, Genl. Div., Structural Geology of Canadian ore deposits: Montreal, Quebec, p. 580-589.

Cooper, R. A., 1923, Mineral constituents of the Rand banket: Chem., Metall., Mining Soc. South Africa Jour., v. 23, p. 90-95.

1926, Platinum specimens from Onverwacht mine: Chem., Metall., Mining Soc. South Africa, v. 26, p. 228-230. 1928, A new platinum mineral in the Rustenburg norites: Chem., Metall., Mining Soc. South Africa Jour., v. 28, p. 281-283.

Corless, C. V., 1929, The Frood ore deposit; a suggestion as to its origin: Canadian Inst. Mining and Metallurgy Trans., $v$.32, p. 140-146.

Cotelo Neiva, J. M., 1945, Possibilidade de ocorrência de platina no distrito de Braganca [Portugal], Possibilité de trouver du platine dans le district de Bragança: Portugal, Serviças Fomento Mineiro Estudoes, notas e trabalhos, v. 1, p. 6-12 (in Portuguese; French summary).

1946, Cromite, platina, silicatos, niqueliferos e silicatos cobaltiferos em rochas do distrito de Braganca [Portugal]: Portugal Serviços Fomento Mineiro Estudas, notas e trabalhos, v. 2, p. 1-21.

1947, Platina no distrito de Braganca (Platinum in the Bragança district, Portugal): Portugal, Serviças, Fomento Mineiro Estudoes, Notas e Trabalhos, v. 3, p. 19-25 (in Portuguese, English summary).

__ 1948, Rochas e minérios da região Bragança-Vinhais: Portugal Serviço Fomento Mineiro [Relatorio], no. 14, 251 p. (in Portuguese, English summary).

- 1949, Geology and genesis of Portuguese ores of chromium and platinum, Bragança district: Coimbra Univ. Mus. e Lab. Mineralóg. e Geol. Mem. e. Notícias, no. 24, $289 \mathrm{p}$.

Cotter, G. de P., 1924, The mineral deposits of Burma: Rangoon, Supt. Govt. Printing, 41 p.
Cousins, C. A., 1959a, The Bushveld igneous complex: Mining Jour., London, v. 253, no. 6,470, p. 160-162.

1959b, The Bushveld igneous complex; the geology of South Africa's platinum resources: Platinum Metals Rev., v. 3 , no. 3 , p. 94-99.

- 1959c, The structure of the mafic portion of the Bushveld igneous complex: Geol. Soc. South Africa Trans., v. 62, p. 179-201.

Crocco, Giovanni, 1950, The magnetite deposit of St. Leone (Cagliari, Sardinia) I: Seminar facolta sci. Rend., Cagliari Univ., v. 20, p. 298-323.

Cross, J. G., 1920, Lake Shebandowan nickel deposit: Ontario Dept. Mines, 29th Ann. Rept., $\nabla .29$, pt. 1, 225-234.

Daly, R. A., 1928, Bushveld igneous complex of the Transvaal: Geol. Soc. America Bull., v. 39, p. 703-768.

Daly, R. A., and Molengraaff, G. A. F., 1924, Structural relations of the Bushveld igneous complex, Transvaal: Jour. Geology, v. 32, p. 1-35.

Darling, A. S., 1960, Iridium-platinum alloys; a critical review of their constitution and properties: Platinum Metals Rev., v. 4, no. 1 , p. 18-26.

1961, Rhodium-platinum alloys; a critical review of their constitution and properties: Platinum Metals Rev., pt. 1 , v. 5, no. 2 , p. 58-65, and pt. 2 , v. 5 , no. 3 , p. 97-100. 1962, Gold-platinum alloys; a critical review of their constitution and properties: Platinum Metals Rev., pt. 1, v. 6 , no. 2 , p. $60-77$ and pt. 2 , v. 6 , no. 3 , p. $106-111$.

1963, Cobalt-platinum alloys; a critical review of their constitution and properties: Platinum Metals Rev., v. 7, no. 3 , p. $96-104$.

-_ 1964, The vapour pressures of the platinum metals; a review of some recent determinations: Platinum Metals Rev., v. 8, no. 4 , p. $134-140$.

- 1966, The elastic and plastic properties of the platinum metals: Platinum Metals Rev., v. 10, no. 1, p. 14-19.

Darling, A. S. and Yorke, J. M., 1960, The ruthenium-palladium system: Platinum Metals Rev., v. 4, no. 3, p. 104-110.

Davidson, C. F., 1953, The gold-uranium ores of the Witwatersrand: Mining Mag., จ. 90, p. 73-85.

- 1955, The mineralization of the Witwatersrand: Mining Mag., v. 92, p. 152-156.

Davidson, S. C., 1946, Structural aspects of the geology of Falconbridge nickel mine, Sudbury district, Ontario: Canadian Inst. Mining and Metallurgy Trans., v. 49, p. 496-504.

___ 1948, Falconbridge mine; structural geology Canadian ore deposits: Canadian Inst. Mining and Metallurgy, Jubilee Volume, p. 618-626.

Davies, J. F., 1964, Geology, mineral resources, and the expanding mineral industry of Manitoba: Canadian Mining Jour., จ. 85, no. 4, p. 91-93.

Davies, J. F., 1960, Geology of the Thompson-Moak Lake district, Manitoba: Canadian Mining Jour., v. 81, no. 4, p. 101-104.

Day, D. T., 1905-10, Platinum: U.S. Geol. Survey, Mineral Resources U.S., 1904, p. $359-360 ; 1906$, p. 551-562; 1907, pt. 1, p. 731-732; 1905-09, p. 781-791.

1913, Platinum and allied metals: U.S. Geol. Survey, Mineral Resources U.S., 1912, pt. 1, p. 1055-1059; 1913, pt. 1, p. $445-457$.

De Hautpick, E., 1913, Gold and platinum in Mongolia : Mining Jour., v. 100, p. 107. 
De Jong, W. F., 1925, De structuur van sperryliet: Physica, v. 5, p. 292.

De Morveau, G., 1810, Sur la mine de platine de Saint-Domingue: Annales chimie, et physique, v. 73, p. 334.

- 1812, Sur la mine de platine de Saint-Domingue: Nicholson's Jour., v. 31, p. 77.

Deville, H. S.-C., and Debray, H., 1859, Du platine et des metaux qui l'accompagnent: Annales chimie et physique, ser. 3 , v. 56 , p. $449-481$.

Dickson, C. W., 1904, The ore deposits of Sudbury, Ontario: Am. Inst. Mining, Eng. Trans., v. 34, p. 3-67.

- 1905, The distribution of the platinum metals in other sources than placers: Canadian Mining Inst. Jour., v. 8, p. 192-214.

Dixey, F., 1922, The norite of Sierra Leone: Geol. Soc. London, Quart. Jour., v. 78, p. 299-346.

Doelter, C., and Leitmeier, H., 1932, Handbuch der Mineralchemie; Leipzig, v. 3, pt. 2.

Douglass, F. C. H., and Jaffee, R. I., 1960, Properties of the platinum metals and alloys; an annotated bibliography: Battelle Memorial Inst., 105 p.

Drysdale, C. W., 1915, Geology of the Franklin mining camp, B. C.: Canada Geol. Survey Mem. 56, 246 p.

Drybrough, John, 1932, A nickel-copper deposit on Hudson Bay: Canadian Inst. Mining and Metallurgy Trans., v. 34, p. 157-172.

Dunstan, B., 1920, Platinum: Queensland Geol. Survey Dept. Mines, pub. 268, p. 127-172.

Duparc, C. L., 1925, Les gites platiniferes de l'Oural en relation avec ceux du Transvaal: Schweizer. Mineralog. u. Petrog. Mitt., v. 5, p. 147-172.

Duparc, C. L., and Borloz, A., 1927, Sur la birbirite, une roche nouvelle: Soc. phys. et historie nat. Genève Compte rendu, v. 44, p. 137-139.

Duparc, C. L., and Grosset, A., 1916, Etude comparés des gites platinifères de la Sierra de Bonda [Spain], et de l'Oural: Soc. phys. et histoire nat. Genève Mem., v. 38, p. 253-290.

Duparc, C. L., and Molly, E., 1927, Sur les gisements platinifères du Birbir [Ethiopia] : Schweizer. Mineralog. u Petrog. Mitt., v. 7, p. 413-414, and v. 8, p. 240-257.

Duparc, C. L., and Tikonowitch, M. N., 1920, Le platine et les gites platinifères de l'Oural et $d u$ monde: Genève Soc. Anonyme des Editions Sonor, $542 \mathrm{p}$.

du Toit, A. L., 1911, Report on the copper-nickel deposits of the Insizwa, Mount Ayliff, East Griqualand, Cape of Good Hope : Ann. Rept. Geol. Commission for 1910, p. 111-142.

Edwards, A. B., Anderson, J. S., and Hart, J. G., 1942, On the occurrence of platinum and palladium at the Thomson River copper mine, Victoria, with a note on the optical properties of braggite: Australasian Inst. Mining and Metallurgy Proc., no. 125, p. 61-69.

Elford, H. S., 1932, Osmiridium in Tasmania : Eng. and Mining Jour., v. 133, p. 580-581.

Eliseev, N. A., Gorbunov, G. I., Eliseev, E. N., Malenikov, V. A., and Utkin, K. N., 1961, Ultrabasic and basic intrusives of Pechenga; geology, structure, mineralogy, minerals and ores, geochemistry of nickel: Akad. Nauk SSSR, Lab. Geologii Dokembriya Trudy, no. 10, 350 p. (in Russian).

Elliston, John, 1953, The Moina district: Empire Mining and Metall. Cong., 5th Australia and New Zealand Pub., v. 1, p. 1194-1199.
Eve, G. T., 1935, The western Abyssinian (Ethiopian) plateau : Mining Mag., v. 53, p. 85-88.

Fairbairn, H. W., Hurley, P. M., and Pinson, W. H., 1960, Mineral and rock ages at Sudbury-Blind River, Ontario: Geol. Assoc. Canada Proc., v. 12, p. 41-66.

Falconbridge Nickel Mines, Ltd., 1959, The Falconbridge story : Canadian Mining Jour., v. 80, no. 6, p. 103-230.

Farabee, W. C., 1921, A golden hoard from Ecuador: Pennsylvania Univ. Mus. Jour.,v. 12, p. 43-52.

Faribault, E. R., 1920, Investigations in western Nova Scotia : Canada Geol. Survey Summary Rept. 1919, pt. F, p. 2-20.

Farquharson, R. A., 1913, The platinum placers of Orepuki, New Zealand: New Zealand Inst. Trans., v. 43, p. 471.

Feringa, G., 1959, The geoligical succession in a portion of the nonthwestern Bushveld, Union section, and its interpretation: Geol. Soc. South Africa Trans., v. 62, p. 219-238.

Ferrier, W. F., 1920, Platinum at Mount Ida, Kamloops mining division, B. C. : Munition Resources Commission, Canada, final report, p. 183-185.

Fersman, A. E., 1940, Minerally U.S.S.R. : v. 2, chaps. on pyrrhotite, chalcopyrite, and pentlandite.

Flores, Teodoro, 1938, Criaderos de minerales métalicos, in Blásquez L., Luis, Memoria de la Comisión Geológica del Valle del Mezquital, Hidalgo: México Inst. Geologica, capítulo IV, p. 103-129.

Ford, L. A., 1964, Platinum alloy permanent magnets; the design of magnetic circuits for platinax II: Platinum Metals Rev., v. 8, no. 3, p. 82-90.

- 1966, Cobalt-platinum alloy magnets; effect of high temperatures on magnetic properties: Platinum Metals Rev., v. 10, no. 3, p. 84-86.

Foslie, S., and Johnson-Host, M., 1932, Platina i sulfidisk Nikkelmalm: Norges Geol. Undersökelse Skr., Oslo, no. 137.

Francis, A. V., 1962, Platinum group metals and rhenium: Metallurgie, v. 94, no. 3, p. 233-245.

Freise, F. W., 1933, Platinlagerstätten des brasilianischen Staates Minas Geraes: Metall u. Erz, v. 30, h. 14, p. 271-272.

Freeman, B. C., 1936, Mineral deposits in Renfrew County and vicinity, Ontario: Canada Geol. Survey Mem. 195, pub. $2,417,34 \mathrm{p}$.

Furon, Raymond, 1960, Géologie d'l'Africa: 2d. ed., Paris, Payot, $400 \mathrm{p}$.

-1963, Geology of Africa: Edinburgh-London, Oliver \& Boyd, 377 p. English translation by A. Hallam and L. A. Stevens. - 1963, Geology of Africa [English ed.] : New York, Hafner Publishing Co., $377 \mathrm{p}$.

Galbraith, F. M., and Hart, R., 1939, Geophysics in exploraation at Falconbridge: Canadian Inst. Mining and Metallurgy Trans., v. 42, p. 527-531.

Galloway, J. D., 1932, Lode-gold deposits of British Columbia : British Columbia Dept. Mines Bull. 1, 147 p.

Gaskell, T. F., 1937, The structure of braggite and palladium sulfide: Zeitschr. Kristallographie, v. 96, p. 202-213 (in English).

Geary, J. K., and others, 1956, Platinum group metals: Mineral resources Australia, Summary Rept., v. 39, 25 p.

Gehlen, A. F., 1811, Platin and Palladium in Bjrasilien and St. Domingo gefunden: Schweiggers Jour. f. Chemie, v. 1, p. 362. 
Genkin, A. D., 1959, Conditions of occurrence, and features of the compositions of minerals of the platinum group in ores of the Noril'sk deposits: Akad. Nauk SSSR Inst. Geol. Rudnykh Mestorozhdeniy, no. 6, p. 74-84 (in Russian).

Genkin, A. D., and Basova, G. V., 1965, New data on minerals of the U.S.S.R.: Tr. Mineral Muzeya, no. 16, p. 209 (in Russian).

Genkin, A. D., and Korolev, N. V., 1961, On methods of determining small grains of minerals in ore: Akad. Nauk SSSR, Geol. Rudnykh Mestorozhdeniy, no. 5, p. 64-69 (in Russian).

Genkin, A. D., Murav'eva, I. V., and Troneva, N. V., 1966, Zvyagintsevite; a natural intermetallic compound of palladium, platinum, lead, and tin: Akad. Nauk SSSR, Geol. Rudnykh Mestorozhdeniy, no. 3, 8 p. (in Russian).

Genkin, A. D., Zhuravlev, N. N., and Smirnova, E. M., 1963, Moncheite and Kotulskite, new minerals; and the composiition of michenerite: Vses. Mineralog. Obshch. Zapiski, v. 92, no. 1 , p. 33-50 (in Russian).

Genkin, A. D., Zhuravlev, N. N., Troneva, N. V., and Murav'eva, I. V., 1966, Irarsite, a new sulfoarsenide of iridium, rhodium, ruthenium, and platinum: Vses. Mineralog. Obshch. Zapiski, v. 95, p. 700-712 (in Russian).

Genkin, A. D. and Zvyagintsev, O. 1., 1962, Vysotskite, a new sulfide of palladium and nickel: Vses. Mineralog. Obshch. Zapiski, v. 91, no. 6, p. 718-925 (in Russian).

Genth, F. A., 1870, Discovery of rhodium gold in San Domingo, 1870: Am. Philos. Soc. Proc., v. 11, p. 438.

Geological Society of America, Toronto Field Trips Committee, 1953, Geology and mineral deposits, Sudbury area, Ontario: Geol. Soc. America-Geol. Assoc. Canada, Ann. Mtg., Toronto, Ont., Nov. 1953, Guidebook for Field Trip no. 7, $15 \mathrm{p}$.

Gill, J. C., 1951a, Geology of the Mystery Lake area, Cross Lake mining division, Manitoba: Manitoba Dept. Mines and Nat. Resources Mines Br. Pub. 50-4, 20 p.

—_ 1951b, Geology of the Waskaiowaka Lake area, Cross Lake mining division, Manitoba: Manitoba Dept. Mines and Nat. Resources Mines Br. Pub. 50-5, $41 \mathrm{p}$.

Gillanders, E. B., 1935, Lisungwe area-gold, platinum, corundum: Nyasaland Geol. Survey Dept., Ann. Rept. 1934, p. 6-14.

Gladhill, T. L., 1921, Iridosmine crystals from Ruby Creek, Atlin district, B. C.: Toronto Univ. Studies, Geol. Ser., no. 12 , p. 40.

Gmelin, Leopold, 1938, 1939, Gmelins Handbuch der anorganischen Chemie, System-Nummer 68, Platin, pt. A, Geschichtliches und Vorkommen, Berlin, Verlag Chemie, p. 1-310.

Godlersky, M. H., 1958, Geologiya i Rudnye Mestorozhdenii Norylskogo raiona: Gornyi Zhur., Moscow, no. 6, p. 9-14.

Golding, E., 1932, Notes on the Wedza platinum mine, Southern Rhodesia: Chem. Metall. Mining Soc. South Africa Jour., v. 33, p. 192-195.

Gonzáles Reyna, Jenaro, 1936, El mineral de Aranjuez, Jalisco, México: Geol. Soc. Mexicana Bol., v. 9, no. 5, p. 239-269.

- 1937, Depósitos de mercurio de "El Moral", Jalisco, México: Geol. Soc. Mexicana Bol., v. 10, nos. 9-12, p. 257-286.

1946, La industria minera en el Estado de Zacatecas, México: México Comite Directivo Inv. Recursas Minerales Bol., no. 4, 127 p.
1946, La industria minera en el Estado de Chihuahua, México: México Comite Directivo Inv. Recursas Minerales Bol., no. 7, 152 p.

- 1946, Informe preliminar sobre la zone minera de Urique Estado de Chihuahua, Mexico : Bol. Minas y Petróleo, t. 17, no. 11, p. 3-6.

1946, Criaderos minerales típicos de México : in Cap. 6 of Guía del explorador minero, México Univ. Nac. Inst. Geol., p. 143-167.

1947, Minera y riqueza minera de México: Banco de México Monografías industriales, 2d ed., p. 446.

Goodchild, W. H., 1916-17, Economic geology of the Insizwa Range : Inst. Mining and Metallurgy Trans., v. 26, p. 12-60 and 76-84.

Graton, L. C., 1930, Hydrothermal origin of the Rand gold deposits: Econ. Geology, v. 25, supp. to no. 3, 185 p.

Griffith, Laurence, 1940, The determination of platinum and palladium in low grade materials: Canadian Inst. Mining and Metallurgy Trans., v. 43, p. 153-158.

Grigorjew, A. T., 1932, Ủber Legierungen des Palladium mit Antimon: Zeitschr. Anorg. u. Allg. Chemie, v. 209, p. 308-320.

Groeneveld Meijer, W. O. J., 1955, The geochemistry of the platinum metals with respect to their occurrence in nickeliferous sulfide deposits [abs.]: Canadian Mining Jour., v. 76 , p. 80 .

Hall, A. L., 1926, The Bushveld igneous complex: Chem. Metall. Mining Soc. South Africa Jour., v. 26, p. 169-171. - 1932, The Bushveld igneous complex of the central Transvaal: South Africa Univ. Dept. Mines and Ind., Geol. Survey Mem. 28, 560 p.

Harrison, J. B., 1924, An occurrence of palladium and rhodium in British Guiana: Memo from "The official gazette," May 3, 1924, $2 \mathrm{p}$.

Harrison, J. M., 1957, The Canadian shield mainland; chapter 2 of geology and economic minerals of Canada: Canada Geol. Survey Econ. Geology Ser. no. 1 (4th ed.), p. 19-122.

Hawley, F. G., 1939, The occurrence of platinum in meteorites : Pop. Astronomy, v. 47, p. 439-444.

Hawley, J. E., 1962, The Sudbury ores; their mineralogy and origin: Canadian Mineralogist, v. 7, pt. 1, 207 p.

Hawley, J. E., and Rimsaite, Y., 1953, Platinum metals in some Canadian uranium and sulfide ores: Am. Mineralogist, v. 38 , p. $463-475$.

Hawley, J. E., Lewis, C. L., and Wark, W. J., 1951, Spectrographic study of platinum and palladium in common sulfides and arsenides of the Sudbury district, Ontario: Econ. Geology, v. 46, p. 149-162.

Hawley, J. E., and Berry, L. G., 1958, Michenerite and froodite, palladium bismuthide minerals [Ontario]: Canadian Mineralogist, v. 6, p. 200-209.

Hayden, H. H., 1915, Mineral production of India: India Geol. Survey Recs. 46, p. 284. 1919, Mineral production of India: India Geol. Survey Recs. 50, pt. 3, p. 156.

Heckroodt, R. O., 1959, The geology around the dunite pipe on Driekop [eastern Transvaal]: Geol. Soc. South Africa Trans., v. 62, p. 59-71.

Henderson, J., 1923, Gold and platinum in the Orepuki district: New Zealand Geol. Survey Br., 17th Ann. Rept. for 1923, p. 13. 
- 1923-24, Notes to accompany a geological sketch map of the Mount Arthur district: New Zealand Jour. Sci. and Tech., v. 6, p. 174-190.

Herior, E. M., 1918, Mining in Spain: Mining Mag., v. 19, p. 132.

Herlinger, N., 1927, Zur Geochemie der Platinmetalle : Zeitschr. Angew. Chemie, v. 40, p. 649.

Hermann, F., and Günther, O., 1936, Über einige wenig bekannte Platinvorkommen der Welt: Metall u. Erz, v. 33, no. 5, p. 113-116.

Hesse, R., 1926, Platinvorkommen in Abessinian: Metall $u$. Lrz, no. 20, p. 572-573.

Hiemstra, S. A., and van Biljon, W. J., 1959, The geology of the upper Magaliesberg stage and the lower Bushveld complex in the vicinity of Steelpoort: Geol. Soc. South Africa Trans., v. 62, p. 239-255.

Hills, Loftus, 1923, An outline of the economic geology of Tasmania: Australasian Inst. Mining and Metallurgy Proc., no. 52, p. 129-147.

Hoffman, G. C., 1888, On a specimen of Canadian native platinum from British Columbia: Royal Soc. Canada Proc. and Trans. 5, pt. 3, p. 17-22.

Horwood, C. B., 1912, Iridosmine from the new Rietfontein mines; its occurrence, analysis, and genesis: Geol. Soc. South Africa Trans., v. 15, p. 51-62.

Howe, E., 1914, Petrographical notes on the Sudbury nickel deposits: Econ Geology, v. 9, p. 500-522.

Howe, J. L., 1918, Stringent regulations on platinum: Chem. and Metall. Eng., v. 19, p. 607-608.

Howitt, A. M., 1917, The East Walhalla copper and platinum mine: Victoria Geol. Survey Rec., v. 4, pt. 1, p. 74-77.

Howley, J. P., 1907, Mining in Newfoundland: Mining World, v. 26, p. 783 .

Hume-Rothery, W., 1966, The platinum metals and their alloys; a review of their electronic structure and constitution: Platinum Metals Rev., v. 10, no. 3, p. 94-100.

Hundeshagen, L., 1904, The occurrence of platinum in wollastonite, on the island of Sumatra, Netherlands East Indies : Inst. Mining and Metallurgy Trans., v. 13, p. 550-552.

Hunt, T. Sterry, 1852, Platinum: Canada Geol. Survey Prog. Rept., 1851-1852, p. 120.

Hussak, Eugene, 1904, U̇ber des Vorkommen von Palladium and Platin in Brasilien: Sitzungsberichte der Kaiserlichen Akad. Wiss. Vienna, v. 113, H. 5-7, p. 379-466.

- 1916, $O$ palladio e a platina no Brasil: Annas da Escola de Minas de Ouro Preto, no. 8, p. 85-188.

Hutchins, J. P., 1914, Dredging in the Russian empire: Eng. and Mining Jour., v. 98, p. 857-862.

Imperial Institute, Mineral Resources Department, 1936, Platinum and allied metals [2d ed]: London, $137 \mathrm{p}$.

Inostransev, A. A., 1893, Die primären Lagerstätten von Platin in Ural: Trudy St. Petersburg, Obsschestwa Estestwoispytatelej, Wypusk II, Otdelenie Geologii, Mineralogii, v. 21, p. 17 (in Russian).

International Nickel Co. of Canada Staff, 1946, Geology of the Sudbury Ontario district, in The operations and plants of International Nickel Company of Canada, Limited: Canadian Mining Jour., v. 67, no. 5, p. 322-331.

Irving, E. M., and Hulin, C. D., 1950, A potential nickel-platinum mine at the Acoje chromite mine, Santa Cruz, Zambales: Philippine Geologist, v. 4, no. 4, p. 11-22.
Iskyul, E. V., 1940a, On the finding of valleriite in the Noril'sk sulfide ores: Acad. Sci. U.R.S.S., Compte rendu, v. 27, no. 3, p. 249-251.

$1940 \mathrm{~b}$, Mineralogy of platinum and palladium in the Noril'sk sulfide ores: Acad. Sci. U.R.S.S., Compte Rendus, v. 27 , no. 3, p. 252-254.

Ivanov, A. A., and Lizunov, N. V., 1944, Platinoids in the ultrabasic rocks of the Urals: Acad. Sci. U.R.S.S., B., Sér. Geól. no. 5, p. 76-86.

Jewell, R. C., 1964, Platinum in the glass industry ; investigating contamination with the electron probe scanning microanalyzer: Platinum Metals Rev., v. 8, no. 4, p. 122-127.

Johnson, Matthey and Co., Ltd., 1957, Physical properties of the platinum metals: Platinum Metals Rev., v. 1, no. 2, p. 61 .

1963, Physical properties of the platinum metals : Platinum Metals Rev., v. 7, no. 4, p. 147.

Johnston, C. W., 1962, Platinum mining in Alaska; dredge and dragline operations at Goodnews Bay: Platinum Metals Rev., v. 6, no. 2, p. 68-74.

Johnston, W. A., 1925, Gold placers of Dease Lake area, Cassiar District, B. C.: Canada Geol. Survey Summ. Rept., pt. A, p. 33-74.

Junner, N. R., 1929, The norite of Sierra Leone: Internat. Geol. Cong. 15th South Africa sess., 1929, commun. 43, p. $417-432$.

1930, Notes on the geology and mineral resources of Sierra Leone: Sierra Leone Studies, no. 16, p. 44-51.

- 1930, The geology and mineral resources of Sierra Leone: Mining Mag., v. 42, p. 73-82.

Karpinsky, A. P., 1926, Sur l'origine probable des gites platinifères primitifs du type ouralien: Acad. Sci. U.R.S.S. Bull., ser. 6, v. 20, p. 133-170.

Kellner, G. J., 1928, Die Platinlagerstätten der Republic Kolombien, Sudamerika : Zeitschr. Prakt. Geologie, v. 36 , p. 1-7.

Kenny, E. J., 1927, Platinum and bismuth near the Razorback: New South Wales Dept. Mines Ann. Rept., p. 129-130.

Kerr, F. A., 1925, Dease Lake area, Cassiar district, B. C. : Canada Geol. Survey Summ. Rept., pt. A, p. 75-99.

Klaus, K. K., 1845, Discovery of a new metal (ruthenium) : Poggendorff's Annalen, v. 64, p. 192-197. - 1847, Mine de Platine, osmium, ruthénium : Jour. Pharmacie et Chimie ser. 3, v. 8, p. 381-385.

Knight, C. W., 1917, Report of the Ontario Nickel Commission: Toronto, p. 110-115 and 117-121.

1920, The Munro nickel area: Ontario Dept. Mines Ann. Rept., v. 29, pt. 1, p. 219-223.

- 1923, The chemical composition of the norite-micropegmatite, Sudbury, Ontario: Econ. Geology, v. 18, p. $592-594$.

Korableff, G., 1939, Le gisement de platine de Joubdo en Abyssinie: Annales Mines, ser. 13, v. 15, no. 7, p. 5-15.

Kovaloff, Paul, 1926, Platinum and platinoid metals, a memorandum based on part 3 of "The geology and world distribution of platinum", 1923: South African Mining and Eng. Jour., v. 37, p. 519-521, 561-562, and 585-587.

Kozkov, I. S., Kitzul, V. I., Rasin, L. V., and Borishanskaya, S. S., 1962, Platinum of Aldan shield: Siberian Branch, Akad Nauk U.S.S.R., Irkutsk Filial, 116 p. (in Russian). 
Krusch, P., 1936, Das Vorkommen des Platins und der Platinmetalle und ihre Verwendung: Metall u. Erz, v. 33, p. 481-487 and 510-515.

Kunz, G. F., 1918, Platinum, with special reference to Latin America: Reprinted from Pan-American Union Bull., Nov. 1917.

1919, Platinum and palladium in Brazil : Pan-American Union Bull., v. 53, p. 408-413.

Kvashneva, V. Ya., 1935, On the platinum content of the Khalilovo and Khabarnino chromites in the southern Urals: Mineral Raw Materials, v. 10, no. 7, p. 19-24 (in Russian).

Lacroix, A., 1918, Le platine à Madagascar: Soc. Française Minéralogie Bull. v. 6, p. 98-99.

Latysh, I. K., 1959, Forms of platinum in Kachkanar-type ores in the Urals: Trudy Gorno-Geol. Inst., Akad. Nauk S.S.S.R., Ural Filial no. 42, p. 3-15 (in Russian).

Lay, Douglas, 1932, Report on McConnell Creek placer area, Omineca Mining division: British Columbia Dept. Mines Bull. 2, p. 1-17.

Leighton, F. W., 1927, Method of cleaning-up on a platinum dredge: Mining Mag., $\nabla .37$, p. 92-94.

Lennon, P. O., 1927, Osmiridium mining in Tasmania: Mining Mag., v. 37, p. 343-349.

Leutwein, F., 1939, The occurrence of some rare elements in metamorphic rocks of the Black Forest: Zentralb. Mineralogie Geologie, 1939-A, p. 123-128 (in German).

Lewis, Clyde L., 1950, The minor elements of the Sudbury ore minerals : thesis, Queens Univ., Dept. Geol. Sci., Kingston, Ontario.

1957, The determination of precious metals in ores: Canadian Mining and Metall. Bull., no. 539, p. 163-167.

Lightfoot, B., 1926, Platinum in Southern Rhodesia: Southern Rhodesia Geol. Survey, short rept. no. 19, 13 p.

1927, Traverse along the Great Dyke: Southern Rhodesia Geol. Survey, short rept. no. 21, 10 p.

Lipovsky, M., 1962, The Transvaal platinum deposits: South Africa Mining and Eng. Jour., v. 37, pt. 2, p. 273-276 and 405.

Lobanov, I. F., 1961, Platinum in the bedrocks of the Vilui Basin: Sovetskaya Geologiya, no. 5, p. 142 (in Russian).

Lockhead, D. R., 1955, A review of the Falconbridge ore deposit, Canada: Econ. Geology, v. 50, p. 42-50.

López, G. F., 1947, Bosquejo geológico del Estado de Aguascalientes, México: Bol. Minas y Petróleo, t. 18, no. 2, p. 3-9.

Lunde, Gulbrand, 1927, Uber das Vorkommen des Platins in norwegischen Gesteine und Mineralien, I: Beitrag zur Geochemie der Platinmetalle: Zeitschr. Anorg. u. Allg. Chemie, v. 161, 1-20.

- 1928, Vorkommen und Nachweis der Platinmetalle in norwegischen Gesteine, II: Zeitschr. Anorg. u. Allg. Chemie, v. 172, p. 167-195.

Macaulay, R. M., 1919, The source of placer platinum in the Tulameen district of British Columbia: Eng. and Mining Jour., v. 107, p. 303-336.

MacKay, B. R., 1921, Beauceville map-area, Quebec: Canada Geol. Survey Mem. 127, p. 83-84.

MacKay, R. A., 1953, The world's sources of platinum : Mining Mag., v. 89, p. 216-218.
MacKenzie, G. C., 1920, An investigation of certain Canadian platinum and manganese resources: Canadian Mining Inst. Trans., v. 22, p. 305-319.

1920, Platinum resources of the Tulameen district, B. C.: Mineral Resources, Canada, final rept., Toronto, p. $147-154$.

Manб, J. C., 1940, Cuencas geológicas y mineralógicas de los departamentos del Quiché, Baja Verapaz y sud de la Alta Verapaz: Soc. Geografía e Historiade Guatemala Anales, t. 16, no. 5, p. 384-400.

Martínez Pérez, Felipe, 1946, Estudio geológico-minera del ex-distrito de San Ignacio, Estado de Sinaloa, México: Bol. Minas y Petróleo, v. 17, no. 12, p. 3-5.

Maslenitskii, I. N., 1948, New platinum minerals in sulfidic copper-nickel ores: Zapiski Leningrad Gorn. Instit., v. 22, no. 2 (in Russian).

Maufe, H. B., 1919, Platinum metals in the Somabula diamondiferous gravels: Southern Rhodesia Geol. Survey, Rept. no. 5 .

McDonald, Donald, 1931, Platinum: Chemistry and Industry, (London), v. 50, p. 1031-1041.

—_ 1960, A history of platinum: London, Johnson, Matthey and Co., Ltd., $254 \mathrm{p}$.

McPherson, G., Jr., and Lamb, T., 1921, Platinum-bearing rocks in the Lizard district, Cornwall: Geol. Mag., v. 58, p. 512-514.

Mella, F., 1921, Black sand deposits of the island of Chiloé, Chile: Eng. and Mining Jour., v. 111, p. 497-501.

Menshutkin, B. N., 1934, Discovery and early history of platinum in Russia: Jour. Chem. Education, v. 11, p. 226-229.

Menyaylov, A. A., 1947, The gabbro-dunite-anorthosite complex and its metallogeny in the Far East, as illustrated by the Ammunakta massif: Acad. Sci. U.R.S.S. Compte Rendu (Doklady), v. 53, p. 351-353 (in Russian).

Menyaylov, A. A., and Naboko, S. Y., 1936, On the question of the occurrence of platinum in the Far East: Acad. Sci. U.R.S.S. (Akad, Nauk), Compte Rendu (Doklady) new ser. v. 3, p. 387-389 (in Russian).

Merensky, H., 1925, The platinum areas of Lydenburg: South Africa Mining and Eng. Jour., v. 36, p. 474-476.

- 1926, Die neuentdeckten Platinfelder im mittleren Transvaal und ihre wirtschaftliche Bedeutung: Deutsche Geol. Gesell. Zeitschr., v. 78, p. 296-314.

Meseguer Pardo, José, 1948, Los metales de la mena del platino: Minería y Metalurgia (Madrid), no. 84, p. 3-13.

Mieleitner, K., 1923, Platin, Gold, and Silber in Kolombien: Edel-Erden u. Erze, v. 4, no. 2, p. 13-15.

Mintern, R. A., 1961, Platinum alloy permanent magnets properties and applications of Platinax II: Platinum Metals Rev., v. 5, no. 4, p. 82-88.

Mitchell, G. P., and Mutch, A. D., 1956, Geology of the Hardy mine, Sudbury district, Ontario: Canadian Inst. Mining and Metallurgy., Trans., v. 59, p. 37-43; Canadian Mining and Metall. Bull., no. 526, p. 75-81; in v. 2 of Canadian Inst. Mining and Mettalurgy, Geology Div., Structural geology of Canadian ore deposits, p. 350-363, 1957.

Moldavantsev, E. P., 1927, Platinum deposits of the Burmantovo region of the northern Ural, with an English summary : Bull. Com. géol. Leningrad, v. 46, p. 141-156.

Molly, E. W., 1934, Le Ouallaga géologique et minier (Ethiopie) : La Chronique des Mines Coloniales (Bur. d'Etudes Géol. et Min. Coloniales), an. 3, no. 29, p. 252-261. 
1959, Platinum deposits of Ethiopia: Econ. Geology, v. 54 , p. $467-477$.

Moorhouse, W. W., 1946, The northeastern portion of the Timagami Lake area: Ontario Dept. Mines, Ann. Rept. for 1942 , v. 51 , pt. 6, 46 p.

Moore, E. S., 1930, Geological structure of the southwest portion of the Sudbury basin: Canadian Inst. Mining and Metallurgy Trans., v. 33, p. 292-302.

1941, Some comparisons of Sudbury with the Bushveld complex [abs.] : Econ. Geology, v. 36, p. 106.

Morgan, P. G., 1927, Minerals and mineral substances of New Zealand: New Zealand Geol. Survey Branch, Bull. 32, p. 76-77, and 81-82.

Morrison, M., 1928, Platinum: the mineral industry of New South Wales: New South Wales, Geol. Surv., p. 119-124.

Mosquera R., Ramón, 1937, Informe científico sobre la región Quibd6-Buenarentura: Minería, Medellín, Colombia (Asoc. Colombiana de Mineros), añ. 5, no. 58, p. 4550-4565.

Nakovnik, N. I., 1931, The basic igneous rocks of northeast Balkhash land, in connection with the discovery of nickel and platinum, with an English Summary: Bull. Geol. Serv. U.S.S.R., v. 1, p. 1173-1177 (in Russian).

Nicholl, J. J., 1925, Platinum in Mexico: Mining Jour., v. 149. p. 352 .

Nicolaysen, L. O., Villiers, J. W. L., Burger, A. J., and Strelow, F. W. E., 1958 , New measurements relating to the absolute age of the Transvaal system and of the Bushreld igneous complex: Geol. Soc. South Africa Trans., v. 61, p. 137-163.

Northern Miner, 1961, The Thompson mine, Manitoba: Northern Miner, magazine supplement, Aug. 17, 1961, p. 40-78.

Nye, P. B., 1929, The osmiridium deposits of the Adamsfield district: Tasmania Dept. Mines, Geol. Survey Bull. no. 39, $70 \mathrm{p}$.

Nye, P. B., and Blake, F., 1938, The geology and mineral deposits of Tasmania: Geol. Survey Tasmania, Bull. no. 44, $113 \mathrm{p}$.

Nye, P. B., and Fisher, N. H., 1954, The mineral deposits and mining industry of Papua-New Guinea : Canberra, Bureau of Mineral Resources, Geology and Geophysics, report no. $9,35 \mathrm{p}$.

Oliveira, E. P. de, 1930, Mineral resources of Brazil: Brazil Serviço Geológie e Mineralógia, p. 25.

Olsacher, J., Chaudet, A., and Ducloux, E. Herrero, 1951, Descripción de dos meteoritos cordobeses : Acad. Nac. Cienc. Córdoba, Argentina, Bol., no. 39, p. 261-273.

O'Neill, J. J., and Gunning, H. C., 1934, Platinum and allied metal deposits of Canada: Canada Geol. Survey, Econ. Geology Ser. no. 13, 165 p.

O'Neill, P. H., 1956, Platinum mining in Colombia, South America : Mining Eng., v. 8, no. 5, p. 496-500.

Ortlepp, R. J., 1959, A pre-Karroo igneous complex at Trompsburg, Orange Free State, revealed by drilling exploration: Geol. Soc. South Africa Trans., v. 62, p. 33-57.

Osann, G. W., 1827, New metals in the Uralian platina: Philos. Mag., 2d ser., v. 2, p. 391-392.

Padalka, G. L., 1936, The periodotite massif Pai-Er on the polar Ural: Arctic Inst. Trans., v. 47, 175 p. (Russian, English summary p. 161-174).
Padurova, O. G., 1930, Sperrylite crystals from Timpton and Zeya areas: Soc. Russe Mineralogie Mem., ser. 2, v. 59, p. 181-185 (in Russian).

Passau, G., 1945, Les gisements auro-platinifères du Kivu (Province Orientale, Congo Belge) : Inst. Royal Colonial Belge, Bull. 16, no. 1, p. 76-92.

Pelzer, E. E., 1950, The Rankin Inlet nickel-copper deposit; a microscopic study: Canadian Mining Jour., v. 71, no. 9, p. 79-83.

Phemister, T. C., 1923-24, A microscopic examination of the Insiswa sulfide deposits: Inst. Mining and Metallurgy Trans., v. 33, p. 519-524.

1926, Igneous rocks of Sudbury and their relation to the ore deposits: Ontario Dept. Mines, 34th Ann. Rept., pt. 8, p. 1-61.

1937, A review of the problem of the Sudbury irruptive; Jour. Geology, v. 65, p. 91-116.

- 1956, The Copper Cliff rhyolite in McKim Township, district of Sudbury : Ontario Dept. Mines, 65th Ann Rept., pt. 1, v. 65 , p. $91-116$.

Poitevin, Eugene, 1924, Platiniferous rocks from Tulameen map area, Yale district, British Columbia, and Ural Mountains, Russia: Canada Geol. Survey Summ. Rept. for 1923, pt. A, p. 84-101.

Pollard, Melvin, 1951, Platinum group metals of Japan : Tokyo, Nat. Resources Sec., Supreme Commander for the Allied Powers, $30 \mathrm{p}$.

Pollett, J. D., 1931, Platinum mining in Sierra Leone: Eng. and Mining World, v. 2, p. 747-748.

Powell, A. R., 1956, La présence des métaux du groupe du platine dans les dépôts alluviaux et primaires: Rev. metallurgie, v. 53, no. 4, p. 298-304.

Preston, Eric, 1960, Platinum in the glass industry: Platinum Metals Rev., pt. 1, v. 4, no. 1, p. 2-9, and pt. 2, v. 4, no. 2, p. 48-55.

-1966, Platinum in the glass industry; the design of protective sheathing: Platinum Metals Rev., v. 10, no. 3, p. $78-83$.

Purington, C. W., 1899, The platinum deposits of the Tura River system, Ural Mountains, Russia: Am. Inst. Mining Engineers Trans., v. 29, p. 3-16.

Quiring, Heinrich, 1962, Die metallischen Rohstoffe, ihre Lagerungsverhältnisse und ihre wirtschaftliche Bedeutung; v. 16, Platinmetalle: Stuttgart, Ferdinand Enke, $288 \mathrm{p}$.

Ramdohr, Paul, 1958, New observations on the ores of the Witwatersrand in South Africa and their genetic significance: Geol. Soc. South Africa Trans., v. 61, annexure, p. 3-50. [English translation of monograph originally published in Germany, 1955.]

1960, Die Erzmineralien und ibre Verwachsungen: Berlin, Akademie-Verlag, $1089 \mathrm{p}$.

Reid, A. M., 1921, Osmiridium in Tasmania: Tasmania Dept. Mines, Geol. Survey Bull. 32, 123 p.

Reid, J. A., 1943, Special report on the mineral resources of the Timiskaming silver-cobalt area, Ontario: Ontario Dept. Mines Bull. 134, 23 p.

Rhodes, E. C., Jahn, C. H., and Dowson, A. G., 1945, The platinum metals industry in Germany: British Intelligence Objectives Sub-Committee, final rept. 441, item no. 21, 68 p. (typewritten). 
Rice, H. M. A., 1947, Geology and mineral deposits of the Princeton map-area, British Columbia: Canada Geol. Survey Mem. 243, pub. 2,477, $136 \mathrm{p}$.

Rogers, W. R., and Young, A. C., 1929, Statistical review of Ontario's mineral industry in 1927: Ontario Dept. Mines 37th Ann. Rept., v. 37, pt. 1, p. 1-68.

Rustenburg Platinum Mines, Ltd., technical advisers, 1957, Platinum mining in the Transvaal; operations at Rustenburg platinum mines: Platinum Metals Rev., v. 1, no. 1, p. $3-8$.

1966, Expansion in platinum production; long and short term plans at Rustenburg: Platinum Metals Rev., v. 10 , no. 2 , p. 52-53.

1967, Further increase in production at Rustenburg: Platinum Metals Rev., v. 11, no. 1, p. 9

- 1967, Further expansion in platinum production; a new refinery in South Africa: Platinum Metals Rev., v. 11, no. 4 , p. 131.

- 1968, One million ounces of platinum; Rustenburg's increased output: v. 12, no. 4, p. 139.

Ruttan, G. D., 1955, Geology of Lynn Lake, Manitoba: Canadian Mining and Metall. Bull. 518, p. 339-348; Canadian Inst. Mining and Metallurgy Trans., v. 58, p. 191-200.

Sastri, B. N., 1917, Platinum in Dhangawan (Jubbulpore district, C. P.) bauxite: Jour. Sci. and Indus. Research, Delhi, v. 6, p. 82.

Saspaeva, T. A., Kalinin, S. K., and Fain, E. E., 1959, A spectrographic study of Dzhezkazgan copper ores for rare and disseminated elements: Akad. Nauk Kazakh. SSR Izv. Ser. Geol., no. 2, p. 68-74. (in Russian).

Saytzeff, A., 1897, Platinum deposits of the Urals: Memoirs of the University of Tomsk, Burdakoff and Son, Tomsk., 95 p. (in Russian).

Scaliger, J. C., 1557, Exotericarum exercitationum Liber XV de Subtilitate ad Hieronymum Candanum, apud Cladium Marnium et haeredes Joannis Aubrii, Francofurti, p. 323324.

Schmidt, E. R., 1953, The structure and composition of the Merensky reef and associated rocks in the Rustenburg platinum mine: Geol. Soc. South Africa Trans., v. 55, 47 p.

Schneiderhöhm, H., 1929, Erdmikroskopische und spektrographische Untersuchung von platinführenden Nickelmagnetkiesgesteinen der Bushveld Igneous Complex: Chemie der Erde, v. 4, p. 252-286.

Schneiderhöhm, H., and Moritz, H., 1931, Spektrographische Untersuchungen über die Verteilung der Platinmetalle in den Mineralien der südafrikanischen Platinlagerstätten: Festschrift zum fünfzigjährigen Bestehen der platinschmelze G. Siebert, p. 257-287.

Shimkin, D. B., 1953, Minerals, a key to Soviet power: Cambridge Mass., Harvard Univ. Press, $452 \mathrm{p}$.

Singewald, Q. D., 1950, Mineral resources of Colombia (other than petroleum) : U.S. Geol. Survey Bull. 964-B, p. 53-204.

Smith, C. H., and Kapp, H. E., 1962, The Muskox intrusion, a newly discovered layered intrusion in the Coppermine River area, Northwest Territories, Canada [abs.]: Am. Mineralogist, v. 47, p. 202-203.

Smith, E. A.. 1925, The platinum metals: I. Pitman and Sons, Ltd., $123 \mathrm{p}$.

Snelgrove, A. K., 1934, Chromite deposits of Newfoundland: Newfoundland Dept. Nat. Resources, Geol. Sect., Bull. 1, $19 \mathrm{p}$.
Sobolewsky, Oberst, 1835, Über das Ausbringen des Platins in Russland: Liebig's Annalen der Pharmacie, v. 13, p. 42-52, Heidelberg.

South Africa Geological Survey, 1955, Geological map of the Republic of South Africa, 4 sheets, compiled by F. C. Truter and P. J. Rossouw: Pretoria, South Africa, scale $1: 1,000,000$.

1960, Geological map of the Republic of South Africa, 259 sheets, compiled under the direction of F. C. Truter, Director: Pretoria, South Africa, scale 1:125,000.

1967, Geological map of the Republic of South Africa, 18 sheets, compiled under the direction of O. R. van Eeden, Director: Pretoria, South Africa, scale 1:250,000.

Speers, E. C., 1957, The age relation and origin of common Sudbury breccia: Jour. Geology, v. 65, p. 497-514.

Spencer, L. J., 1924, Allopalladium from British Guiana: Mineralog. Mag., จ. 20, p. 217-219.

1926, Sperrylite crystals from the Transvaal: Mineralog. Mag., v. 21, p. 94-97.

- 1928, Potarite, a new mineral discovered by the late Sir John Harrison in British Guiana: Mineralog. Mag., v. 21, p. $397-406$.

Spizharskiy, T. N., chief editor with 14 associates, 1959, Geologic map of the Siberian platform, 2d. edition: Leningrad, Ministry of Geology and Mineral Resources; All-Union Scientific Research Geological Institute, 6 sheets, 1 :1,500,000. (In Russian.)

Stanley, E. R., 1921, A contribution to the geology of New Guinea: Bull. Territory Papua, no. 7, p. 1-15.

- 1923, The geology of Papua (to accompany the geological map of the Territory of Papua) : A. J. Mullett, Gov't. Printer, Melbourne, 56 p.

Stanley, G. H., 1927, Platinum and the platinum metals: South African Chem. Inst. Jour., v. 10, p. 3-48.

Stanley, G. H., and Wagner, P. A., 1925, Note on the microstructure of Transvaal platinum: Chem., Metall. and Mining Soc. Africa Jour., v. 25, p. 254-259.

Stauffer, H., 1945, The geology of the Netherlands Indies in Honig, P., and Verdobrn, eds; Science and Scientists in the Netherlands Indies: New York, Board for the Netherlands Indies, Surinam, and Curacoa, p. 320-335.

Stephen, F. B., 1926, Osmiridium in the matrix; the Bald Hill, Tasmania, occurrence: Chem., Eng., and Mining Rev., v. 18 , p. $481-482$.

Stockwell, C. H., ed., 1957, Geology and economic minerals of Canada: Canada Geol. Survey, Econ. Geology Ser. no. 1, 4th ed., $517 \mathrm{p}$.

Stumpfl, E. F., 1961, Some new platinoid-rich minerals, identified with the electron microanalyzer: Mineralog. Mag., v. 32 , p. $833-847$.

- 1962, Some aspects of the genesis of platinium deposits: Econ. Geology, v. 57, p. 619-623.

Stumpfl, E. F., and Clark, A. M., 1965, Hollingsworthite, a new rhodium mineral, identified by electron probe analysis: Am. Mineralogist, v. 50, p. 1068-1074.

Sullivan, C. J., 1959, The origin of massive sulfide ores: Canadian Inst. Mining and Metallurgy, Transactions, v. 62, p. 321-327.

Suslov, S. P., 1961, Physical geography of Asiatic Russia [translated from the Russian by Noah D. Gershevsky]: San Francisco, W. H. Freeman and Co., 594 p. 
Swift, W. H., 1961, An outline of the geology of Southern Rhodesia: Southern Rhodesia Geol. Survey, Rept. no. 50, $73 \mathrm{p}$.

Tanton, T. L., 1922, Palladium-bearing nickel deposit at Shebandowan Lake, Thunder Bay district, Ontario: Canada Geol. Survey Summ. Rept. for 1922, pt. D, p. 1-8.

Tasmania Geological Survey, 1961, Geological atlas, zone 7, sheet no. 52, Du Cane [Tasmania] (ed. 1) : Hobart, Tasmania Geol. Survey, 1 mile series.

Tennant, Smithson, 1805, On two metals found in the black powder remaining after the solution of platina: Nicholson's Jour., v. 10, p. 24-30. [from the Philosophical Trans. for 1804]

Thomson, A. G., 1951, South African platinum metals: Mining Jour., v. 237, p. 160-161.

Thomson, J. E., 1957a, Geology of the Sudbury basin: Ontario Dept. Mines Ann. Rept. 1956, v. 65, pt. 3, 6. 1-56.

1957b, Recent geological studies in Sudbury camp: Canadian Mining Jour., v. 78, no. 4, p. 109-112. 1959, Geology of Falconbridge township: Ontario Dept. Mines Ann. Rept. 1957, v. 66, pt. 6, 36 p.

- 1960, Symposium on occurrence of massive sulfide deposits in Canada; part IV, "Massive sulfide occurrences in Ontario": Canadian Min. and Metall. Bull., v. 53, no. 575, p. $136-140$.

Thomson, J. E., Ferguson, S. A., Johnston, W. G., Q., Pye, E. G., Sarage, W. S., and Thomson, Robert, 1957, Copper, nickel, lead, and zinc deposits in Ontario: Ontario Dept. Mines, Metal Resources Circ. 2, 126 p.

Thomson, J. E. and Williams, Howel, 1959, The myth of the Sudbury lopolith: Canadian Mining Jour. v. 80, no. 3, p. $57-62$.

Tremblay, Maurice, 1946, Statistical review of the mineral industry of Ontario for 1941: Ontario Dept. Mines Ann. Rept. v. 51, pt. 1, 282 p.

Turban, Federico, 1947, Estudio de la mineralización a la profundidad en los minerales de Pachuca y Real del Monte, Estado de Hidalgo, México: Bol. Minas y Petróleo, v. 18, no. 1, p. $3-6$.

Twelvetrees, W. H., 1914, The Bald Hill osmiridium field: Tasmania Dept. Mines, Geol. Survey Bull. 17, 41 p.

Uglow, W. L., 1911, The Alexo nickel deposit, Ontario: Ontario Dept. Mines, v. 20, pt. 2, p. 34-39.

- 1920, Douglas gold-platinum gravels, North Saskatchewan River, Alberta: Mineral Resources Commission, Canada, Final Report, Toronto, p. 185-194.

1921, Possibilities for platinum in western Canada: Canadian Mining Inst. Monthly Bull., no. 95, p. 207-220; Canadian Mining Inst. Trans., v. 23, p. 374-389.

Ulloa, Anthonio de, 1748, Relación Histórica del Viage á la América Meridional, v. 1: Madrid, Antonio Marín, chap. 10, p. 606.

Vakhrushev, G. V., 1940, Exploration of rare elements in Bashkiriya, southern Ural: Uchenye Zapiski Saratov Gosudarst, Univ. N. G. Chernysherskogo, v. 15, no. 1, p. 124 146.

Vincente, M. J., and Restrepo, Alonzo, 1958, Monografía sobre el platino del Chocó: Ministerio de minas y petróleos, división nacional de minas, Bol. Minas, no. 54, p. 16-56.
Vines, R. F., and Wise, E. M. (ed.), 1941, The platinum metals and their alloys: New York, The International Nickel Co., Inc., $141 \mathrm{p}$.

Vinogradov, A. P., 1944, Geochemistry of the scattered rarer elements in sea water: Uspekhi Khimii, v. 13, p. 3-34 (in Russian)

Vsesoyuznogo Nauchno-Issledovatel skogo Geologischeskogo Instituta, (VSEGEI) 1959, Geologicheskaya karta Sibirskoi platformy : $2 \mathrm{~d}$ ed., 6 sheets, scale $1: 1,500,000$, Moscow, U.S.S.R.

Vysotskiy, N. K., 1933, Ural and Siberia platinum fields, the geology and world distribution of platinum, Part 5 : Leningrad, Akad. Nauk SSSR, 240 p. (in Russian).

Wagner, P. A., 1924, Magmatic nickel deposits of the Bushreld complex: South Africa, Geol. Survey, Mem. 21.

- 1925, Notes on the platinum deposits of the Bushveld complex: Geol. Soc. South Africa Trans., v. 28, p. 83-133.

- 1925, The platinum deposits in the western part of the Lydenburg district, Transvaal: South African Jour. of Industries, v. 8, p. 90-113.

1926, Recent discussion on the origin of the Bushveld platinum deposits: Geol. Soc. South Africa Trans., v. 29, p. 145-147.

1926, Occurrence of the platinum metals in South Africa : Econ. Geology, v. 21, no. 2, p. 109-134, no. 3, p. 243-270.

1926, Preliminary report on the platinum deposits in the southeastern part of the Rustenburg district: South Africa Geol. Survey, Mem. 24, 39 p.

1929, The platinum deposits and mines of South Africa: Edinburgh, Oliver and Boyd, $326 \mathrm{p}$.

Wagner, P. A., and Mellor, E. T., 1925, On platinum-bearing hortonolitedunite of the Lydenburg district: Geol. Soc. South Africa Trans., v. 28, p. 1-17.

Wagner, P. A., and Trevor, T. G., 1923, Platinum in the Waterberg district: South Africa Jour. Ind., v. 6, p. 577-597.

Walker, T. L., 1897, Geological and petrographical studies of the Sudbury nickel district, Canada: Geol. Soc. London Quart, Jour., v. 53, p. 40-66.

1935, Magmatic differentiation as shown in the nickel intrusive at Sudbury: Toronto Univ. Studies Geol. Ser., no. 38 , p. $23-30$.

Wandke, A., and Hoffman, R., 1924, A study of the Sudbury ore deposits: Econ. Geology, v. 19, p. 169-204.

Watson, R. J., 1928, Platinum-bearing nickel-copper deposit on Lower Shebandowan Lake, district of Thunder Bay: Ontario Dept. Mines, Ann. Rept., v. 37, pt. 4, p. 128-149.

Watson, William, 1750, Several papers concerning a new semimetal called platina: Royal Soc. London Philos. Trans., v. 46 , p. 584-596, 671-676.

Weeks, L. J., 1932, Rankin Inlet area, west coast of Hudson Bay, Northwest Territories: Canada Geol. Survey Summ. Rept. 1931, pt. C, p. $37-46$.

Wells, H. L., 1889, Sperrylite, a new mineral: Am. Jour. Sci. 3d ser., v. 37, p. 67-70.

White, G. A., 1915, Tasmanian nickel deposits: Mining Mag., v. 12 , p. $103-105$.

White-Uribe, H. E., 1940, Contribucion al estudio minerogeológico del Tolima $\mathbf{y}$ sobre el origen del platino: Rev. Minería, Medellín, Colombia (Assoc. Colombiana Mineros), v. 17, no. 101-102, p. 8538-8543. 
Whitworth, H. F., 1931, The mineralogy and origin of the natural beach sand concentrates of New South Wales: Royal Soc. New South Wales Jour. and Proc., v. 65, pt. 1 , p. $59-74$.

Willemse, J., 1959, The "floor" of the Bushveld igneous complex and its relationship, with special reference to the eastern Transvaal, [presidential address]: Geol. Soc. South Africa Proc., v. 62, p. 21-83.

Williams, Howel, 1957, Glowing avalanche deposits of the Sudbury basin: Ontario Dept. Mines Ann. Rept. 1956, v. 65 , pt. 3, p. 57-89.

Wilson, H. D. B., and Anderson, D. T., 1959, The composition of Canadian sulfide ore deposits: Canadian Inst. Mining and Metall. Trans., v. 62, p. 324-337.

Wilson, H. D. B., and Brisbin, W. C., 1959, Regional structure of the Thompson-Moak Lake nickel belt: Canadian Inst. Mining and Metallurgy Trans., $\nabla .64$, p. 470-477.

Wöhler, F., 1866, Über ein neues Mineral von Borneo: Annalen der Chemie und Pharmacie, v. 139, p. 116-120.

Wöhler, L., 1930, Über Platinarsenid : Zeitschr. anorg. Chemie, v. 186, p. 324-326.

Wollaston, W. H., 1805, On a new metal found in crude platina: Nicholson's Jour., v. 10, p. 34-42.

Woodring, W. P., Brown, J. S., and Burbank, W. S., 1924, Geology of the Republic of Haiti: Haiti Dept. Public Works, Port-au-Prince, 631 p.

Worley, W. F., 1923-24, Platinum in alluvium from Nelson mineral belt rocks: New Zealand Jour. Sci. and Tech., v. 6, p. 136-138.

Wright, J. F., 1932, Geology and mineral deposits of a part of southeastern Manitoba: Canada Geol. Survey Mem. 169, $150 \mathrm{p}$.

Wysotsky, N. K., 1932-1933, Platinum and the districts in which it is worked: Izdanie Komissii estestwenjch proizwoditelnych syl pri Akademii Nauk, v. 4, p. 1-343, Petrograd. (in Russian)

Yates, A. B., 1938, The Sudbury intrusive: Royal Soc. Canada, Trans., 3d ser. $\nabla .32$, p. 151-172.

- 1948, Properties of the International Nickel Co. of Canada, Ltd., in Canadian Inst. Mining and Metallurgy, Geol. Div., Structural geology of Canadian ore deposits: Jubilee volume, p. 596-617.

Yavnel, A. A., 1950, Spectrographic analysis of the SikhoteAlin meteorite: Meteoritika, Acad. Sci. U.S.S.R., no. 8, p. 134-148 (in Russian).

Young, R. B., 1907, Notes on the auriferous conglomerates of the Witwatersrand: Geol. Soc. South Africa Trans., v. 10, p. 17-30.

- 1917, The Rand banket; a study of the auriferous conglomerates of the Witwatersrand and the associated rocks: London, $125 \mathrm{p}$.

Zavaritsky, A. N., 1928, Primary platinum deposits of the Urals, (Russian with French summ.) : Comité géologique materiaux pour la géologie générale et appliquée, livraison 108, Leningrad, p. 1-56.

Zealley, A. E. V., 1918, The occurrence of platinum in Southern Rhodesia: Southern Rhodesia Geol. Survey, Rept. no. $3,6 \mathrm{p}$.

Zhuravlev, N. N., Genkin, A. D., and Stepanova, 1968, X-ray diffraction characteristics of the Norilsk cooperite, (in Russian) : Zap. Vses. Minera, Obshchest, Moscow, U.S.S.R.
Zontov, N. S., 1959, The geological structure of the coppernickel deposit of the northern part of Rudnaya Mountain (Norilsk region) : Acad. Sci. U.S.S.R., v. 1, no. 5, p. 3-20. Abstract in English, Econ. Geology, v. 56, 1961, p. 1001.

Zurbrigg, H. F., 1957, The Frood-Stobie mine in "Structural geology of Canadian ore deposits": Canadian Instit. Min. and Metall., v. 51, p. 341-350.

- 1962, Thompson mine geology: Canadian Instit. Min. and Metall. Bulletin, v. 56, p. 451-460.

Zur Muhlen, Leo von, 1936, Die Platinlagerstätten am Birbir in Westabessinien: Metall. u. Erz. Jahrg. 33, Bd. 13, p. 349-353.

Zvyagintsev, O. E., 1932, Forms of occurrence of platinum group metals, (in Russian): Tavetnie Metal., nos. 7-8, p. $140-145$.

1932, Forms in which platinum and allied metals occur in nature, (in Russian): Ann. Inst. Platin, no. 10, p. 14-33.

1940, New mineral species of the platinum group, (in Russian) : Akad Nauk SSSR Doklady, v. 26, no. 8.

1940, New mineral species of the platinum group called Noril'skite, an alloy of $\mathrm{Pt}, \mathrm{Fe}, \mathrm{Ni}(\mathrm{Cu}, \mathrm{Pd})$ : Akad. Nauk SSSR Doklady, v. 36, p. 778-791 (in Russian).

- 1946, On geochemistry of palladium: Voprosy mineralogii, geokhimii, i petrografii (in Russian) ; Akad. Nauk SSSR, p. 199-208 (translated from Russian by V. P. Sokoloff).

1950, Ruthenium geochemistry: Izv. Sektora Platiny i Brug. Blagorod. Metal. Inst. Obshchei i Neorg. Khim., Akad. Nauk SSSR, v. 25, p. 129-137 (in Russian).

\section{UNITED STATES BIBLIOGRAPHY}

Alaska, Irving Reed, Supervisory Mining Engineer, 1933, Mineral investigations and mine inspections in Alaska ...., biennium ending March 31, 1933: Juneau, Alaska, p. 103126.

Baker \& Co., Inc., undated, Data concerning platinum, 15th edition: Newark, N.J., Baker \& Co., Inc., 72 p.

Bancroft, Howland, 1910, Platinum in southeastern Nevada [Clark County]: U.S. Geol. Survey Bull. 430, p. 192-199.

Beamish, F. E., 1966, The analytical chemistry of the noble metals: Oxford and New York, Pergamon Press, Ltd., $609 \mathrm{p}$.

Bell, J. E., 1956, Platinum group metals, in Mineral facts and problems: U.S. Bur. Mines Bull. 556, p. 695-702.

Bishop, J., and Co. (Johnson, Matthey \& Co.), 1931, Technical and industrial platinum: Malvern, Pa., J. Bishop and Co., p. 1-116.

Blake, W. P., 1854, On gold and platinum of Cape Blanco, California: Am. Jour. Sci., $2 \mathrm{~d}$ ser., v. 18, p. 156.

Bradley, W. W., and others, 1924, Mining in California: California State Min. Bur., v. 20, p. 87.

Brooks, A. H., 1922, The Alaskan mining industry in 1920: U.S. Geol. Survey Bull. 722, p. 1-74.

Buddington, A. F., and Chapin, Theodore, 1929, Geology and mineral deposits of southeastern Alaska: U.S. Geol. Survey Bull. $800,398 \mathrm{p}$.

Capps, S. R., 1931, Glaciation in Alaska: U.S. Geol. Survey Prof. Paper 170, p. 1-8.

Cathcart, S. H., 1922, Metalliferous lodes in southern Seward Peninsula: U.S. Geol. Survey Bull. 722, p. 163-261. 
Chapin, Theodore, 1919, Platinum-bearing auriferous gravels of Chistochina River, Alaska: U.S. Geol. Survey Bull. 692, p. 137-141.

Chapman, C. A., and Schweitzer, G. K., 1945, Trace elements in rocks of the Oliverian magma series of New Hampshire: Am. Jour. Sci., v. 245, p. 597-613.

Clark, F. W., 1924, The data of geochemistry, 5th ed.: U.S. Geol. Survey Bull. 770, 841 p.

Collins, J. J., 1944, Green Mountain copper mine; an interpretations of results of U.S. Bureau of Mines War Project 1454 ; U.S. Bur. Mines, 7 p.

Coulter, C. C., 1936, The platinum group discovery at Centennial, Wyoming: Mining Jour. [Phoenix, Ariz.], v. 20, no. 6 , p. 5 .

Crampton, F. A., 1916, Platinum at the Boss mine, Goodsprings, Nevada : Mining and Sci. Press, v. 112, p. 479-482.

Dana, E. S., 1932, A textbook of mineralogy; 4th ed., New York, John Wiley \& Sons, Inc., p. 406-407.

Day, D. T., and Richards, R. H., 1907, Black sands of the Pacific slope; U.S. Geol. Survey Mineral Resources U.S., 1905, p. 1175-1258.

De Ment, J. A., 1946, Rarer metals: New York, Chemical Publishing Co., $392 \mathrm{p}$.

Deville, H. S-C., and Debray, H., 1859, Du platine et des métaux qui l'accompagnent: Annales Chemie et Physique, v. 56, p. $449-481$.

Doelter, C., and Leitmeier, H., 1932, Handbuch der Mineralchemie: Leipzig, v. 3, pt. 2.

Dudley, W. L., 1885, Iridium, with a bibliography of 149 references from 1803-1885: U.S. Geol. Survey Resources U. S., 1883-84, p. 581-591.

Duparc, Louis, 1924, Sur les gisements platinifères du Wyoming: Soc. phys. et histoire nat. Genève Compte Rendu, v. 41 , no. 2 , p. $102-104$.

Duparc, C. L., and Tikonowitch, M. N., 1920, Le platine et les gites platinifères de l'Oural et du monde: Genève, Soc. Anonyme des Editions Sonor, $542 \mathrm{p}$.

Eakle, A. S., 1922, Minerals of California: California State Mining Bur. Bull. 91, p. 23-25.

Eckel, E. B., 1938, Copper ores of the La Plata district, Colorado, and their platinum content: Colorado Sci. Soc. Proc., v. 13 , p. $647-664$.

- 1947, La Plata district, La Plata and Montezume Counties, in Vanderwilt, J. W., Mineral Resources of Colorado: Denver, Colo., Mineral Resources Board, p. 416-419.

Eckel, E. B., and others, 1949, Geology and ore deposits of the La Plata district, Colorado with sections by J. S. Williams, F. W. Gailbraith, and others: U.S. Geol. Survey Prof. Paper 219, 179 p. [1950].

Emmons, S. F., 1903, Platinum in copper ores in Wyoming: U.S. Geol. Survey Bull. 213, p. 94-97.

Engelhard Industries, Research and Development Division, 1965, The physical properties of the noble metals: Technical Bulletin, v. 6, no. 3, p. 61-96.

Engelhard, C. W., 1963, Uses of platinum metals: Eng. and Mining Jour., v. 164, p. 119.

Finch, J. W., 1925, Platinum discoveries in Wyoming (Encampment district); Eng. and Mining Jour.-Press, v. 120, p. 95-96.

Fraser, H. J., 1937, Microchemistry of the precious metal elements : Am. Mineralogist, v. 22, p. 1016-1034.
Gardner, E. D., and Johnson, C. H., 1934, 1935, Placer mining in the western United States: U.S. Bur. Mines Inf. Circ. IC-6786, (1934) 73 p., IC-6787 (1934) 89 p., IC-6788 (1935) $81 \mathrm{p}$.

Gilchrist, Raleigh, 1943, The platinum metals: Chemical Rev., v. 32 , no. 3 , p. 227-372.

Gmelin, Leopold, 1938, 1939, Gmelins Handbuch der anorganischen Chemie, system-nummer 68, Platin, Teil A, Geschichtliches und Vorkommen: Berlin, Verlag Chemie, p. 1-310.

Graton, L. C., 1930, Hydrothermal origin of the Rand gold deposits: Econ. Geology, v. 25, supp. to no. 3, 185 p.

Graves, T. A., 1939, The examination of placer deposits: New York, Richard R. Smith, 168 p.

Gregory, H. E., and Moore, R. C., 1931, The Kaiparowits region, a geographic and geologic reconnaissance of parts of Utah and Arizona: U.S. Geol. Survey Prof. Paper 164, $148 \mathrm{p}$.

Griffith, W. P., 1967, The chemistry of the rarer platinum metals (Ir., Os., Ru., Rh.) : New York, Interscience Publishers, Inc., $491 \mathrm{p}$.

Groeneveld Meijer, W. O. J., 1955, Niggliite, a monotelluride of platinum?: Am. Mineralogist, v. 40, p. 693-696.

- 1955, Synthesis, structures, and properties of platinum metal tellurides: Am. Mineralogist, จ. 40, p. 646-657.

Gruetter, T. W., 1916, Platinum in Compton mines, Grant County, Oregon: Eng. and Mining Jour., v. 101, p. 1135.

1916, Platinum on the Pacific coast: Mining Sci. Press, v. 113, p. 20.

Hale, F. A., Jr., 1914, Platinum ore in southern Nevada, Boss Mine: Eng. and Mining Jour., v. 98, p. 641.

Harrington, G. L., 1919a, The gold and platinum placers of the Tolstoi district, Alaska: U.S. Geol. Survey Bull. 692, p. 339-351.

$1919 \mathrm{~b}$, The gold and platinum placers of the KiwalikKoyuk region, Alaska: U.S. Geol. Survey Bull. 692, p. $369-400$.

Hawley, F. G., 1939, The occurrence of platinum in meteorites: Pop. Astronomy, v. 47, p. 439-444.

Hess, F. L., 1926, Platinum near Centennial, Wyoming: U.S. Geol. Survey Bull. 780, p. 127-135.

Hess, H. H., 1960, Stillwater igneous complex, Montana, a quantitative mineralogical study : Geol. Soc. America Mem. $80,230 \mathrm{p}$.

Hewett, D. F., 1931, Geology and ore deposits of the Goodsprings quadrangle, Nevada: U.S. Geol. Survey Prof. Paper 162, 172 p.

Hill, J. M., 1915-18, Platinum and allied metals: U.S. Geol. Survey Mineral Resources U.S. 1914, pt. 1, p. 333-352; 1915 , pt. 1 , p. $139-157 ; 1916$, pt. 1 , p. $1-20 ; 1917$, pt. 1 , p. 11-21

- 1923, Platinum and allied metals in 1922: U.S. Geol. Survey Mineral Resources U.S., 1923, pt. 1, p. 125-135.

Hite, T. H., 1933, Fine gold and platinum of Snake River, Idaho: Econ. Geology, v. 28, p. 256-265.

Hornor, R. R., 1918, Notes on the black sand depasits of southern Oregon and northern California: U.S. Bur. Mines Tech. Paper 196, $42 \mathrm{p}$.

Howe, J. L., and Holtz, H. C., 1919, Bibliography of the metals of the platinum group; platinum, palladium, iridium, rhodium, osmium, ruthenium, 1748-1917: U.S. Geol. Survey Bull. 694, 588 p. 
Howe, J. L., and staff of Baker and Co., Inc., 1947, Bibliography of the platinum metals, 1918-1930: Newark, N. J., Baker and Co., Inc., $138 \mathrm{p}$.

- 1949, Bibliography of the platinum metals, 1931-40: Newark, N. J., Baker and Co., Inc., 248 p.

- 1956, Bibliography of the platinum metals, 1941-1950: Newark, N. J., Baker and Co., Inc., 93 p.

Howland, A. L., Peoples, J. W., and Sampson, Edward, 1936, The Stillwater igneous complex and associated occurrences of nickel and platinum-group metals: Montana Bur. Mines and Geology Misc. Contr., no. 7, 15 p.

Imperial Institute, Mineral Resources Department, 1936, Platinum and allied metals: 2d ed., London, $137 \mathrm{p}$.

Jackson, E. D., and others, 1954, Geologic maps and sections of the eastern part of the complex in Stillwater County, Montana: U.S. Geol. Survey open-file report.

- 1961, Primary textures and mineral associations in the ultramafic zone of the Stillwater complex, Montana: U.S. Geol. Survey Prof. Paper 358, 106 p.

Johnson, C. H., and Atkinson, R. H., 1937, Some points of interest to the chemical engineer; platinum and allied metals: Inst. Chem. Eng. (London) Trans., v. 15, p. 131-144.

Kellogg, A. E., 1919, Placer mining in Oregon (Waldo district, Josephine County) : Eng. and Mining Jour., v. 108, p. 90-91.

- 1922, Platinum in the quartz veins of southwest Oregon: Eng. and Mining Jour.-Press, v. 113, p. 1000.

- 1929, Platinum in southwestern Oregon: Mining Jour. (Phoenix, Ariz.), v. 12, p. 5-6.

Kellogg, L. O., 1915, Platinum in Oro Mingo mine (Platina), Clark County, Nevada, and Boss Mine: Eng. and Mining Jour., v. 99, p. 388 and 796.

Kemp, J. F., 1902, The geological relation and distribution of platinum and associated metals: U.S. Geol. Survey Bull. 193, 95 p.

1904, Platinum in the Rambler mine, Wyoming: U.S. Geol. Survey Mineral Resources U. S., 1902, p. 244-250.

—_ 1926, General geological relations of platinum: Eng. and Mining Jour. Press, v. 121, p. 717-719.

Kennedy, G. C., and Walton, M. S., Jr., 1946, Geology and associated mineral deposits of some ultrabasic rock bodies in southeastern Alaska: U.S. Geol. Survey Bull. 947-D, p. $65-84$.

Kennedy, J. C., 1915, Occurrence of platinum at the Boss mine, Nevada: Mining World, v. 42, p. 939-940.

Knopf, Adolph, 1915a, A gold-platinum-palladium lode in southern Nevada: U.S. Geol. Survey Bull. 620, p. 1-18.

- 1915b, Platinum at the Boss mine: Mining and Sci. Press. v. 110, p. $867-879$.

1942, Ore deposition in the pyrometasomatic deposits, in Newhouse, W. H., ed., Ore deposits as related to structural features: Princeton, N. J., Princeton Univ. Press,, p. 63-72.

Kromayer, A., 1862, Platine de Californie (sable noirs): Archiv. pharm., v. 110, Jahresber. 1862, p. 707.

Kunz, G. F., 1921, Platinum: Mineral Industry 1921, v. 30, p. 554-573. [Collocation of localities in which the presence of platinum metals has been shown is given on p. 566569.]

Liddell, D. M., 1945, Handbook of nonferrous metallurgy, $\nabla$. 2: New York, McGraw-Hill Book Co., Inc., p. 287-288 and 701-705.
Lindgren, Waldemar, 1911-12, Platinum and allied metals: U.S. Geol. Survey Mineral Resources U.S., 1909, pt. 1, p. $595-601 ; 1910$, pt. 1 , p. $773-780 ; 1911$, pt. 1, p. 987-1003.

1919, Mineral deposits: 2d ed., New York, McGraw Hill Book Co., 957 p.

Logan, C. A., 1919, Platinum and allied metals in California: California Div. Mines and Geology Bull. no. 85, 120 p.

Lumb, A. D., 1920, The platinum metals: London, J. Murray, $63 \mathrm{p}$.

MacNeil, F. S., Mertie, J. B., Jr., and Pilsbry, H. A., 1943, Marine invertebrate faunas of the buried beaches near Nome, Alaska : Jour. Paleontology, v. 17, p. 69-96.

Maddren, A. G., 1919, The beach placers of the west coast of Kodiak Island, Alaska: U.S. Geol. Survey Bull. 692, p. 299-319.

McCaskey, H. D., 1902, Platinum and associated rare metals in placer formations: Bur. of Public Printing, p. 3-8.

McDonald, Donald, 1958. The history of the melting of platinum; two hundred years of progress: Platinum Metals Rev., v. 2, no. 2, p. 55-60.

- 1959, The platinum of New Granada, I: Platinum Metals Rev., v. 3, no. 4, p. 140-145.

- 1960a, The platinum of New Granada, II : Platinum Metals Rev., v. 4, no. 1, p. 27-31.

- 1960b, A history of platinum: London, Johnson, Matthey and Co., Ltd., $254 \mathrm{p}$.

1968, The first platinum refiners; the French goldsmiths and the arsenic process: Platinum Metals Rev., v. 12 , no. 4, p. $142-145$.

Mertie, J. B., Jr., 1919, Platinum-bearing gold placers of the Kahiltna Valley, Alaska: U.S. Geol. Survey Bull. 692, p. 233-264.

1920, The Salt Chuck palladium-copper mine, Prince of Wales Island, Alaska: Eng. and Mining Jour., v. 110, p. 17-20.

1921, Lode mining in the Juneau and Ketchikan districts, Alaska: U.S. Geol. Survey Bull. 714, p. 121.

— 1923, The occurrence of metalliferous deposits in the Yukon and Kuskokwim regions, Alaska : U.S. Geol. Survey Bull. 739, p. 158.

- 1931, Notes on the geography and geology of Lituya

Bay, Alaska: U.S. Geol. Survey Bull. 836, p. 117-135.

1937, The Yukon-Tanana region, Alaska: U.S. Geol. Survey Bull. 872, 276 p.

— 1938, The Nushagak district, Alaska: U.S. Geol. Survey Bull. 903, 96 p.

1939, Platinum deposits of the Goodnews Bay district, Alaska: U.S. Geol. Survey Bull. 910, p. 115-145.

1940a, Placer gold in Alaska: Washington Acad. Sci. Jour., v. 30, no. 3, p. 93-124.

- 1940b, The Goodnews platinum deposits, Alaska: U.S. Geol. Survey Bull. 918, 97 p.

- 1942, Tertiary deposits of the Eagle-Circle district, Alaska: U.S. Geol. Survey Bull. 917, p. 213-264.

Mertie, J. B., Jr., Fischer, R. P., and Hobbs, S. W., 1951, Geology of the Canyon Ferry quadrangle, Montana: U.S. Geol, Survey Bull. 972, 97 p.

Mertie, J. B., Jr., and Harrington, G. L., 1924, The RubyKuskokwim region, Alaska: U.S. Geol. Survey Bull. 754, p. 104 and 106. 
Moffit, F. H., 1913, Geology of Nome and Grand Central quadrangles, Alaska: U.S. Geol. Survey Bull. 533, 140 p.

Mudd, S. W., 1915, The Boss mine, Goodsprings, Nevada: Mining and Sci. Press, v. 110, p. 297.

Oregon Department of Geology and Mineral Industries, 1939, Oregon metal mines handbook, northeastern Oregon, east half, Oregon: Oregon Dept. Geology and Mineral Industries, Bull. 14-A, 125 p.

Page, N. J., and Jackson, E. D., 1967, Preliminary report on sulfide and platinum-group minerals in the chromitites of the Stillwater Complex, Montana, in Geological Survey Research, 1967: U.S. Geol. Survey Prof. Paper 575-D, p. D123-D126.

Palache, Charles, Berman, Harry, and Frondel, Clifford, 1944, Dana's system of mineralogy, 7th ed., v. 1: New York, John Wiley \& Sons, Inc., 843 p.

Pardee, J. T., 1929, Platinum and black sand in Washington: U.S. Geol. Survey Bull. 805, p. 1-15. 1934, Beach placers of the Oregon coast: U.S. Geol. Survey Circ. 8, 41 p.

Parks, H. M., 1925, A review of the mining industries of Oregon: Mining and Metallurgy, v. 6, p. 14.

Penfield, S. L., 1889, On the crystalline form of sperrylite: Am. Jour. Sci., v. 37, p. 71-73.

Pilipenko, P. P., 1915, Discovery of platinum in black sand in Lincoln County and Jefferson County (Deschutes River), Oregon: Eng. and Mining Jour., v. 99, p. 261 and 428.

Platinum Metals Review, published quarterly by the Johnson Matthey Group, incorporating J. Bishop \& Co. Platinum Works, 1957 to date. Malvern, Pa.

Quiring, Heinrich, 1962, Die metallischen Rohstoffe, ihre Lagerungsver-hältnisse und ihre wirtschaftliche Bedetung; v. 16, Platinmetalle: Stuttgart, Ferdinand Enke, 288 p.

Read, T. J., 1905, Platinum and palladium in certain copper ores: Eng. and Mining Jour., $\nabla .79$, p. 985-988.

Sample, R. D., 1942, Report on the Green Mountain copper mine, Revais Creek district, near Dixon, Sanders County, Montana: U.S. Geol. Survey War Minerals Inv., 14 p.

Selwood, P. W., 1956, Magnetochemistry : 2d ed., New York, Interscience Publishers, Inc., p. 355-364.

Shenon, P. J., 1933, Geology and ore deposits of the TakilmaWaldo district, Oregon: U.S. Geol. Survey Bull. 846, p. 141-194.

Smith, P. S., 1910, Geology and mineral resources of the Solomon and Casadepaga quadrangles, Seward Peninsula, Alaska: U.S. Geol. Survey Bull. 433, 234 p.

1929, Mineral industry in Alaska in 1926 : U.S. Geol. Survey Bull. 797, p. 1-50.

Stumpfl, E. F., 1962, Some aspects of the genesis of platinum deposits: Econ. Geology, v. 57, p. 619-623.

Symons, H. H., 1943, California mineral production and directory of mineral producers: California Div. Mines Bull. $126,224 \mathrm{p}$.

Taft, H. H., 1918, A Wyoming platinum mine: Eng. and Mining Jour., v. 106, p. 900.

Thevenet, J. V., 1860, Sur les gisements aurifères et platinfères de l'Oregon: Acad. de Lyon, Cl. des sci., v. 10, p. 129.

Turner, H. W., 1922, Platinum in quartz veins: Eng. and Mining Jour., v. 113, p. 488-489.

Tyler, Paul, and Santmyers, R. M., 1931, Platinum: U.S. Bur. Mines Inf. Circ. 6389, 69 p.
Uglow, W. L., 1919, Geology of platinum deposits, pts. I and II : Eng. and Mining Jour., v. 108, p. 352-355 and 390-393.

U.S. Bureau of Mines, 1933-68, Minerals Yearbook: Washington, D. C., U. S. Govt. Printing Office (annual publication).

1904-68, Mineral Trade Notes: Washington, D. C., U. S. Govt. Printing Office (monthly publication).

U.S. Geological Survey, 1924-31, Mineral Resources of the United States: Washington, D. C., U. S. Govt. Printing Office (annual publication; continued by U. S. Bur. Mines, Minerals Yearbook, 1932 to date).

Vanderwilt, J. W., and others, 1947, Mineral resources of Colorado: Denver, Colo., Mineral Resources Board, 547 p.

Vogt, J. H. L., 1927, Geology of the platinum metals: Econ. Geology, v. 22, p. 321-355.

Wager, L. R., and Brown, G. M., 1957, Funnel-shaped layered intrusions: Geol. Soc. America Bull. 68, p. 1071-1075.

Wagner, P. A., 1927, The pipe form of ore deposit: Econ. Geology, v. 22, p. 740-741.

Way, Katherine, Fanno Lilla, Scott Millicent, and Thew, Karin, 1950, Nuclear data: Nat'l. Bur. Standards Circ., 499 , p. $110-123$ and $221-230$.

Weeks, M. E., 1932, The discovery of the elements VIII, the platinum metals: Jour. Chem. Education, v. 9, p. 10171034

Weeks, M. E., and Leicester, H. M., 1968, Discovery of the elements, 7th edition: Easton, Pa., Jour. Chem. Education, $896 \mathrm{p}$.

Weil, F., 1859, Platinerze aus Californien: Armengards génie industriel, p. 262.

Wells, H. L., 1889, Sperrylite, a new mineral : Am. Jour. Sci. 3d ser., v. 37, p. 67-70.

Westland, A. D., and Beamish, F. E., 1958, The chemical analysis of iridosmines and other platinum-metal minerals : Am. Mineralogist, v. 43, p. 503-516.

White, A. M., and Friedman, H. B., 1932, On the discovery of palladium: Jour. Chem. Education, v. 9, p. 236-245.

Wilson, H. D. B., 1956, Structure of lopoliths: Geol. Soc. America Bull., v. 67, p. 289-300.

Wise, E. M., 1953, The platinum metals, Chap. 15 of Modern uses of nonferrous metals: $2 d$ ed., New York, American Institute of Mining and Metall. Engineers, p. 288-317; reprinted with changes, 1955, by Platinum Metals and Applied Physics Section, Development and Research Division, The International Nickel Co., Inc., New York, p. 288-323.

Wise, E. M., and Gilchrist, Raleigh, 1949, The platinum metals, alloys, and compounds (Wise); and coordination compounds (Gilchrist) : New York Interscience Encyclopedia, Inc., reprinted (1954) by Development and Research Division, The International Nickel Co., Inc., New York, p. 819-860.

Wright, C. W., 1915, Geology and ore deposits of Copper Mountain and Kasaan Peninsula, Alaska: U.S. Geol. Survey Prof. Paper 87, 110 p.

Wright, T. L., and Fleischer, Michael, 1965, Geochemistry of the platinum metals: U.S. Geol. Survey Bull. 1214-A, p. A1-A24. 


\section{INDEX}

A

Adamsfield district, Tasmania

Aftonian Interglaciation, western Alaska ...... 83 Ainsworth mining district, British Columbia. 98

Alasko, lodes

Alexo mine, Ontario......................... 25

Allopalladium (eugenesite)

Alloys, natural, of platinum metals

Alluvial deposits, Ural Mountains

Alluvial deposits containing platinum........

Almo Lake, Kenora Mining division, Ontario. Analyses and chemical properties of platinum.

Anglo-American Corp. of South Africa, Ltd .

Applegate district, Oregon..................... 100

Arsenopalladinite.

Australia platinum deposits

platinum produ

\section{B}

Basal Complex, oldest rocks of Transvaal.... Battery Reef group, Witwatersrand............ Beaverite.

Bolleterre district, Quebec

Big Flat, Colombla

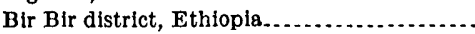

Birbirite.

Bird Reef group, Witwatersrand.

Bismutite

Black reef conglomerate, Transvaal............

Black Reef series, Transvaal...................

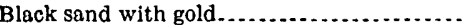

Bojite, Sudbury district.......................

Borneo and Sumatra, platinum deposits.....

Boss mine, Nevada. .........................

Braggite................................... 13, 14, 4

British Columbia, placers

platinum lodes........................... $\quad 28$

platinum production.....................

Broken Hill district, New South Wales.......

Bronzite..................................... 40

Bronzitite..................................... 35. 38

Bushveld igneous complex of Transvaal ...... 16

platinum-bearing nickel-copper ores. $33,94,44,97$

platinum metals

\section{C}

Cable claim and Nome claim, Ainsworth mining division, British Columbia...............................

Callfornia, deposits of platinum dredges as source of platinum............ 76 placers...................................... 91 platinum production . ...................

Cameron mine, Oregon $\quad 99$

Canada, platinum deposits..................... 18 platinum placers........................ 2 production of platinum .................. 4

Cape of Good Hope Province.................. 33, 48 Cascade properties, British Columbia . ...... 29 Centennial mine, Albany County, Wyo . . ... 14, 101

Chalcopyrite........................ 22, 24, 40, 45, 86

Chclmsford sandstone, Ontario.............. 19
[Italic page numbers indicate major references]

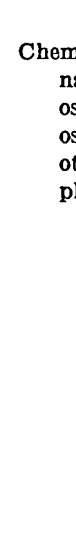

Daneskin-Kamen area, dunite locality ........ 52

Deep Gravel mine, Oregon.................. 100

Density of the platinum metals............ 5

Detrital orlgin of gold of Witwatersrand...... 47

Detrital platinum........................... 45

Detroit-Algoma mine, Ontario................ 25

Diamagnetic gold and silver...................

Didessa district, Ethiopia..................... 4

Discovery and present mining of platinum in Sudbury district.................. 18

Discovery of platinum in Goodnews Bay district, Alaska....................

Distribution of platinum deposits............ 14

Dolomite series, Transvasl..................... 44

Dredge 2, Nóvita and Carmen Valleys, Colombia ............................

Dredge 6, San Juan Valley, Colombia.........

Dredging on Nechi River, Antioquia..........

Driekop deposit, Transvasl....................

Driekop mine, Transvaal. ......................

Dross of natural platinum alloys.............. 10,86

Dunite $17,28,29,40,42,43,48,51,52,54,56,68$ $66,79,81,84$

platinum and osmiridium lodes............ 17

Ural Mountains........................... 51, 56

Dunite ores, Republic of South Africa........

$\mathbf{E}$

Eby township lode, Ontario................ 25 Electrical industries uses of platinum metals..
Errington mine, Sudbury district.............. 21, 22 Ethlopia, platinum deposits.................. 49 platinum production.................. 4

$\begin{array}{lll}\text { Eugenesite. } & 14 \\ \text { Exploration in Alaska. } & \end{array}$

Falconbridge East mine, Sudbury district.... 19

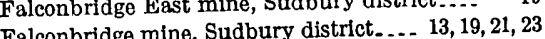
Falconbridge Nickel Mines, Ltd.............. 19 Fecunis Lake mine, Sudbury district......... 19 Ferguson Lake lode, Northwest Territories ... $\quad 28$ Ferguson Lake lode, Northwest Temical com pounds...........................

platinum metals........................... 5

Ferroplatinum Fifield district, New South Wales. ......... 71 Fifield district, New South Flotation concentrates of the Sudbury district. $\begin{array}{r}23 \\ 18,95\end{array}$ Flour goid.................. 18, 95 Fossils, Ural Mountains.................... $\quad 57$ French Flat mine, Oregon..................... Frood series, Ontario .................... 20 Frood-Stobie mine, Sudbury district. . ....... 19, 21

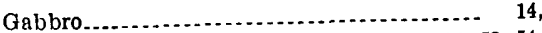
$16,20,26,28,30,35,39,40,48,51,53,54$, $60,66,74,75,76,95,96$

Garewaia area, dunite locality 52 Garson mine, Sudbury district. ............. 19, 21 
Page

Genesis of Sudbury deposits..................... Geography of Intendencia del Chocó....

Aistrict. ................ Sudbury district............................ Witwatersrand system, Transvaal and Orange Free State.................

Geversite news Bay district

Glaciation on Seward Peninsula...............

Gladkala-Sopka area, dunite locality .........

Gold, byproduct from Katanga . ............. detrital origin. . .............................. occurrence in conglomerates............. used as a generic term . ...................

Gold deposits of the Witwatersrand . . ........

Gold fields of Witwatersrand.

Gold Hill mine, Oregon...................... 98

Gold in the placers of Salmon River, Goodnews Bay district..................

Gold lodes, Chocó district.................... 68

Gold placers . . ............................. 29, 31, 32

Gold-platinum placer mining, California.. 91,92,93

Gold-platinum placers, Colombia ............ 14, 66

Ethiopia. . .............................. 50

Goenoeng-Lawack . . ....................... 73

Gold production from Witwatersrand.........

Gold to platinum ratio, Takilma-Waldo district............................ 99

Goodnews Bay district, Alaska, placers... 14, 76, 77 Goodnews platinum district, earlier and recent surveys. . . . .

Goodro mine, Alaska......................... Goussewi-Kamen area, Ural Mountains. ..... Granogabbro..

Granophyre in the Sudbu

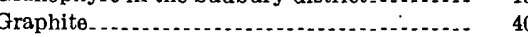
Great Dike, Rhodesia $\ldots . . . . . .48,49$ Great Eastern mine, Clark County, Nev..... 14 Green Mountain copper mine, Montana Grossularite, Sumatra ......................

H

Hardy mine, Sudbury district..............

Heavy minerals, Goodnews Bay district..... in placers.

Ural Mountains Heazelwood district, Tasmania.............. High Gravel mine, Oregon . ................ Highland mine, Oregon ....................... History and production of Witwatersrand.... Hititrite mine, Manitoba. . ................... Hollingsworthite ............................

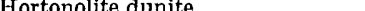
Huronian age rocks of Sudbury basin......... 19 Hyalosiderite................................... Hydrothermal ore, Republic of South Africa.

\section{I}

Idaho, platinum deposits Illinoian Glaciation, Goodnews Bay distric Inferior chemical analyses of platinum metals. Insizwa deposit, Cape of Good Hope Province. Intendencia del Chocó, Colombia............. International Nickel Co., of Canada, Ltd . ... Intrusive rocks of the Sudbury district . . ..... Irarsite..

Iridium, chemical analyses market prices relative amount in Sudbury ore........ Iridium and osmium ratios, Ural Mountains.. Iridosmine...

Iridosmium, term as used by Palache, Berman, and Frondel.................. Iron, byproduct from Katanga.
$\mathbf{J}$

Page

Japan, platinum metals.

\section{$\mathbf{K}$}

Kaap system, Transvaal

Kamenouchly area, dunite locality

Kanjakowsky area, dunite locality ..........

Kansan Glaciation, Goodnews Bay district.

Kaolin

Karroo system, Transvagl

Kasaan Peninsula.............................

Katanga, copper deposits.

platinum production

Kenora mining division, Ontario ..............

Kimberly group, Witwatersrand

Kirkwood mine, Sudbury district

Koswinsky-Kamen area, dunite locality

Koswite, Ural Mountains

Kotulskite.

\section{$\mathbf{L}$}

La Plata mining district, Colorado . . . ......... 95 Laurite............................. 11, 13, 14, 40, 74 Lead, byproduct from Katanga ............ 48 Levack mine, Sudbury district................ 19, 21 Liquidus curves for platinum metals........ 9 Lithified placers, Witwatersrand............ 14, 45-47 Little Stobie, mine, Sudbury district......... 19 Livingston group, Witwatersrand.............. $\quad 46$ Llano de Oro mine, Oregon.................... $\quad 99$ Lode production of platinum. Logan mine, Oregon

Lojok alluvials, Ural Mountains

Loskop system, Transvaal

Lydenburg district, mining of platinum......- 33

$$
\mathbf{M}
$$

$39,41,45,48$

McKim graywacke, Ontario

MacLennan mine, Sudbury district

Magaliesberg quartzite, Transvaal. .............

Magmatic segregates, Republic of South Africa ............................

Magnetic susceptibility of the platinum metals.......................................

Magnetite .................................. 22 recovered with platinum metals... $31,60,68,86$ Main Reef group, Witwatersrand.............. 46

Main Reef Leader, Main Reef group...........

Main Reef proper, Main Reef group ...........

Makwiro platinum field, Rhodesia............

Manitoba platinum deposits...................

Maple Leaf in Franklin mining camp, British Columbia..........................

Merensky platinum reef.................... 39

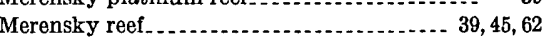

Merensky zone.................. 16, 28, 33, 38, 39,62

ratio of platinum to palladium........... $\quad 41$ Meteorites, platinum bearing ................. $\quad 17$

Michenerite.................................... 13, 22

Micropegmatite of Sudbury basin............. 20

Milnet mine, Sudbury district................. $\quad 25$

Millerite ore mineral........................... $\quad 40$

Mineral deposits formed by magmatic segregates. ...........................

Mineralization, history, Ural Mountains....... Mineralogy of the platinum metals .............

Mining and production of platinum in Alaska. Miscibility of platinum metals.................

Mississagi quartzite, Ontario...................

Modderfontein B banket, Transvaal, osmiridium.............................

Modderfontein B mine, Transvaal............ 45, 47

Monchegorsk lode, Kola Peninsula............ 62

Moncheite. 13

Montana, placer platinum.................. $\quad 97$

platinum deposits...........................
Pege

Monzotonalite ............................... 20

Mooihoek lode, Transvaal................. 42

Mother Lode Claim, British Columbia....... 29, 98

Mount Barjernaja,'deposit, Noril'sk district.- 60

Mount Ida, British Columbia................ $\quad 29$

Mount Rudnaya, Noril'sk district............. $\quad 60$

Murray mine, Sudbury district............. 19, 21

Muskox intrusion, Northwest Territories..... 28

$\mathbf{N}$

Nama system, Transvaal.

Nariño province, Colombia

34

Native alloys of platinum metals

Native platinum metals

Natural alloys of platinum metals.......... 11

Nevada platinum deposits..................... 97

Nevyanskite.............................. 12

New Rietfontein mine, Orange Free State.... $\quad 45$

New South Wales, platinum deposits......... 69, 71

New Zealand, platinum deposits............. 78

Nickel, byproduct from Katanga............. 48

Nickel-copper deposit, principal, in Yukon... 32

Nickel-copper deposits, Norway............... $\quad 75$

Petsamo district. Kola Peninsula.........

Nickel-copper lodes, Manitoba

Sudbury district..........................

Nickel-copper mine at Thompson, Manitoba. .

Nickel-copper ores.

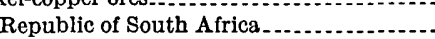

Nickel irruptive

Nickel Offset mine, Sudbury district..........

Nickel Plate mine, British Columbia.........

Nickeliferous pyrite. . ...........................

Niggliite . . . . . . . . . . . . . . .

Nishniy-Tagil district, Ural Mountains....... 51,

Noril'sk district. ........................... 60

,

$20,21,22,33,34,35,37,38,39,40,41,42,48$, $49,50,75,95,96,97$

Norite belt, discovery of platinum............ 33

Norite in the Sudbury district................. 19

Norite lopolith, Bushveld complex............. 34, 35

North of Gillenbine lead, New South Wales... 72

Northwest Territories, platinum-bearing nickel-copper lode..................

Obleiskaya-Kamenska area, Ural Mountains _ $\quad 56$

Occurrence of platinum metals native gold. ............................ 90,91

Oil industry use of platinum metals. ......... 3

Oiseau (Bird)-Maskwa Rivers area, Manitoba_ 27

Olivine dunite . . .................................

Olivine norite, Sierra Leone................... 50

Olson Bench claim, Goodnews Bay district...- 79

Omoutnaia area, dunite locality............... $\quad 52$

Onaping mine, Transvaal.................. 19

Onaping tuff, Ontario ........................ 19, 21

Ontario platinum deposits.................... 18

Onverwacht complex, Transvaal............. 42

Onverwacht lode, Transvaal................. 42

Onwatin slate, Ontario ....................... 19, 21

Orange Free State, gold deposits. . .

Orange Free State and Transvaal provinces, general geology .....................

Ore deposits of the Sudbury district............

Ore minerals from Rankin Inlet lode, Northwest Territories, .................

Oregon, platinum deposits . .................... platinum production. ......................

Osmiridium, analyses from Colombia ......... commercial and generic designation ....... found in South Africa.

Hokkaido Island, Japan. ................. lodes.

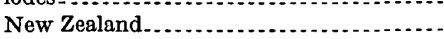

(1)

(1)

(1)

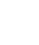

.

.

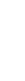

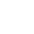

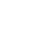


Osmiridium-Continued Page production in Witwatersrand district...... 45,46 term as used by Mertie...... 12 term as used by Palache, Berman, and Frondel........................ 11 Tasmania.............................. 70 world's principal source _................. 2,33

Osmiridium placer, Black Reef conglomerate, Transvaal........................ 45

Osmium, chemical analyses, Witwatersrand... 48,69 magnetic susceptibilities................... 11 market prices...

Osmium and iridium ratios, Ural Mountains.

Pacific beaches of Oregon

Palladinite.

Palladite.

Palladium, market prices relative amount in Sudbury ore......... 23 used as generic term ........................ 11 U.S.S.R.

Palladium-bearing base-metal lodes Palladium-bearing sulfides. Papua, Territory of New Guinea, and Netherlands, Now Guinea...............

Pardee township lode, Ontario . .............

Peck mine, Oregon Pentlandite............................ 22, 24, 40,45 Petsamo district, Kola Peninsula......... 62

Peridotite...... 1 $14,16,25,27,28,29,30,39,42,51,70,73,91,95,99$ as a source rock for platinum............. Peridotites and perknites, sources of most placers......................... 17

Perknite............................... 1, 14, 16, 48

Pertinax II.....................................

Petsamo district, Kola Peninsula..............

Petsamo lode, Kola Peninsula................

Physical properties of, platinum metals.....

Physiography of Ural Mountains..............

Picrite, platinum-bearing rock, Cape of Good Hope Province.....................

Pilandsberg district, platinum lodes. .......... 33, 39

Placer deposit platinum metals ................. 11

Placer deposits in Ural Mountains............ $\quad 56$

Placer mining claims in Goodnews Bay district.....................................

Placer platinum metals of the Urals and Alaska...........................

Placers, British Columbia...................

California.............................

Chocó province, Colombia................

Goodnews Bay district, Alaska.......... 14, 77

Montana................................ 97

other Alaskan deposits. . . ..................

platinum......................................

United States.

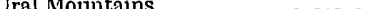

Platerica mine, Oregon.

Platina lead, Now South Wales

Platiniferous placer gold, Alaska.............

Platinum, commercial and generic designation. first discovery in Transvaal................ market prices.............................. relative amount in Sudbury ore...........

Platinum alloys native, Onverwacht mine, Transvaal.....-

Platinum-bearing base-metal lodes.............

Platinum-bearing gold placers, Canada.......

Colombia.

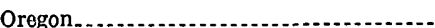

Platinum-bearing lodes, Alaska........... others in Ontario.

Platinum-bearing meteorites

Platinum-bearing min plex, Montana...................

Platinum-bearing nickel-copper ores.

Platinum-bearing placers in British Columbia
Page

Platinum-bearing sulfides in Canada......... 18, 40 Platinum Creek, Goodnews Bay district..... 81

Platinum deposits.......... 14

Goodnews Bay district................... 80

Hokkaido Island, Japan...................

other deposits of Canada................

in the United States..................... 14

minor, U.S.S.R............ 69

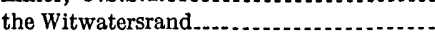

Platinum deposit lodes, classification.........-

Platinum-gold ratios, Colombia..............

Platinum group of metals, components.......

Platinum lodes................................. 14,

Platinum lodes in Alaska, search.............

Platinum metals, Australia...................... detrital origin..................................... in gold ores.

native state-..-...

occurrence in conglomerates

physical properties

Sudbury district.

Platinum metals and gold, Goodnews district

Platinum nuggets, Goodnews Bay district.... Sierra Leone..

Ural Mountains.

Platinum-palladium ratio for Noril'sk de-

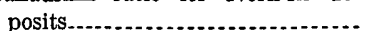

Platinum placers

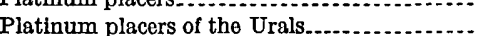

Pleistocene chronology, Goodnews Bay district..................................

Plumbojarisite...

Pneumatolytic ore, Republic of South Africa

Porpezite

Potarite................................................ 14, 76

Potgietersrust district, Transvaal ............. 39, 41

Potgietersrust platinum lode, Transvaal...... 33

Preparation of samples for analysis.............

Pretoria district, Transvaal, platinum mining

Pretoria series, Transvaal......................... 34, 44

Processing of platinum metals...............

Production, total, platinum in Republic of South Africa

Production of ore and history of Witwaters-
rand.........
Production and sources of platinum in Canada.

Production and sources of platinum in Canada.

Production of platinum, Ethiopia..........
Oregon.

roduction of platinum metals from Tulameen district, B.C........................

Pyrite, ore mineral........................... 22, 66

Pyrolusite ore mineral............................

Pyroxenite . ................................... 1 $16,28,29,30,33,35,39,40,42,43,49,50,51$ $53,54,56,58,66,67,79$

Pyrrhotite, ore mineral ............... 22, 24, 40,45

\section{Q}

Quebec platinum deposits.

Queensland platinum deposits $-{ }_{-1}$

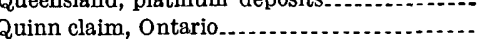

$\mathbf{R}$

Rambler mine, Albany County, Wyo........ 14, 101 Rankin Inlet lode, Northwest Territories, mean tenors of nickel and copper. Rathbun township lode, Sudbury district.... Reaume township lode, Ontario .............. Recovery of platinum metals from refineries. Red Granite, Transvaal

Red Mountain, Goodnews Bay district, platinum metals in dunite
Page

Republic of South Africa, platinum deposits. roduction of platinum metals.

Republic of the Congo (Katanga) copper deposits.

Rhodesia, platinum deposits. . . .

Rhodian sperrylite.

Rhodium, market prices

relative amount in Sudbury ore...........

Richmond River district, New South Wales. Rooiberg group, Bushveld igneous complex... Rudnaya Gora, Noril'sk district........... Russian production of platinum metals...... Rustenburg district, Transvaal, platinum lodes.......................... 33, 39,41

Rustenburg mine, Transvaal............... 39,40

Rustenburg Platinum Mines Ltd. of South Africa.......................... 4,

Ruthenian hollingsworthite................ 13

Ruthenium, chemical analyses ....... 48 market prices.................................. not determined in U.S.S.R.............. relative amount in Sudbury ore..........

Salt Chuck mine, Kasaan Peninsula, Alaska Sangamon Interglaciation, Goodnews Bay district. Sappho property, British Columbia.......... Scottle Creek, British Columbia............ Search for platinum lodes in Alaska..... Secondary platinum metals..................... Selukwe district, Rhodesia.................... Selundi Hills, Rhodesia..................... Separation of platinum metals............ Sericite, ore mineral Serpentinite

$16,17,27,29,42,43,49,51,53,54,70,72,73,74,75$ $79,91,99$

platinum and osmiridium lodes.......... 17 Shebandowan nickel-copper property, Ontario -

Shi Shi Beach, Washington.................... Siberia, minor platinum deposits............. Sierra Leone, platinum deposits.

platinum production Sinala-Gora and Kiedrowska areas, Ural Mountains..........................

Siserskite...

Smuggling of platinum from Colombia....... Solidus curves for platinum metals ........... Solubilities of the platinum metals............. Sosnowsky-Ouwal area, dunite locality ....... Sotnikovskol deposit, Noril'sk district......... Sources and production of platinum in Canada.

South African production of platinum metals. South Reef, Main Reef group, Transvaal..... Specularite, ore mineral ....................... Sperrylite............. 13, 18, 22, 24, 40,43,49,61, 1 analyses. ........................................... spectrographic analyses................... Stannopalladinite............................ Stannoplatinite............................... Stibiopalladinite........................... 13, 14, Stillwater Complex, Montana.................. Stoble group, Ontario.......................... Stream placers, gold-platinum, California and Colombia

Ural Mountains Sudbury basin, Ontario ......................... Sudbury deposits, genesis. . . . . . . .............. Sudbury district platinum deposits.

Sudbury series, Ontario......................... Sulfle breccia, Thompson mine, Manitoba... Sullivan mine, British Columbia............... Sumatra and Borneo, platinum deposits......
76

84 
Superior chemical analyses of platinum...... 10 Swaziland system, oldest rocks of Transvaal _. 34

46,47

Swede group of claims, British Columbia..... 28 Swetli-Bor area, dunite locality ............... Ural Mountains.

\section{$\mathbf{T}$}

Tagil area, dunite locality

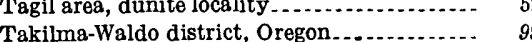

Tasmania, platinum deposits................. 69,7

Tasmanian osmiridium...................... 70

Tenor, ore at Onverwacht mine............. 43

ore at Thompson mine, Manitoba.......... 26 platinum in Humboldt County, California

platinum in Red Mountain...............

platinum metals, Gordon Lake, Ontario Insizwa deposit, Cape of Good Hope Province.

Sudbary ore -....-.

Union mine, Transvaal

Solt Chuck 0

Terrace deposits, Ural Mountains ............

Thompson district, Manitoba.

Thompson mine, Manitobe

Tilaite, Ural Mountains

Timiskaming Series, Ontario

TokaIsky area, Ural Mountains.................

Total production of platinum from Canada.

Totten mine, Sudbury district

Transvaal, first discovery of platinum........ platinum deposits

Transvaal and Orange Free State provinces,

general geology $\ldots \ldots \ldots \ldots$
Transvaal system............................. $34,44,45$
Page

Troctolite, Sierrs Leone

Trout Creek conglomerate, Ontario...........

Tulameen group of rocks, British Columbia . $\quad 29$

Tulameen placer district, British Columbia.. $\quad 29$

$\mathrm{U}$

Union mine Transvaal __ $39,40,98$

Union of Soviet Socialist Republics, history and production of platinum..... production of platinum

production of platinum metals.............
Upper Witwatersrand series, Transvaal.......

Ural Mountains, discovery of platinum ....... platinum placers.

Uralian placers, principal types.

Uralian platinum lodes and placers..........

Uralian platinum samples.

Use of platinum, earlie

Uses of platinum metals.

\section{$\mathbf{v}$}

Vaalkop-Zwartfontein body, Transvaal....... Ventersdorp system, Transvaal.............. 34, 46 Vermilion mine, Sudbury district.......... 18, 21, 22

Victoria, platinum deposits................... 69

Victoria and Queensland...................... 72

Violarite, ore mineral......................... 40

Vysotskite

W

Walhalla copper mine, Victoria $\ldots . . . \ldots \ldots \ldots . .72$

Washington, platinum deposits............... 101

Waterberg district, ratio of platinum to palladium...........................
Fitg

Waterberg platinum lode, Transvaal.........

Waterberg system, Transvaal.................

Wedza mine, Rhodesia...................... 49

Wehrlite, Onverwacht mine, Transvaal....... 43

Wellgreen lode, Yukon......................

Weressowy-Ouwal area, dunite locality ....... $\quad 52$

Ural Mountains .... 56,58

West Point mining district, California ....... 98

Whitewater series, Sudbury basin ............. 19

Wisconsin glaciation, Ural Mountains.......... 50 western Alaska...

Witteberg series, Cape of Good Hope Province. $\quad 48$

Witwatersrand, gold mining

history and production..................... 45

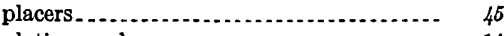

platinum placers........................... 14

production of platinum metals............ 4

Witwatersrand system....................... 34

general geology, Transvaal $\ldots \ldots \ldots \ldots \ldots$

Wollastonite, Sumatra......................... 74

World production, compilation by country.... 5

World production of platinum ................ 4

World's total production of platinum metals ...

Worthington mine, Sudbury district........... 19, 21

Wyoming, platinum deposits.

$\mathbf{Y}$

Yellow Pine mining district, Nevada......... 97

Yukon platinum deposits

$\mathbf{Z}$

Zambia, copper deposits.

Zinc, byproduct from Katanga

Zvyagintsevite

Zvyaginzevite 